\title{
Bringing down the mountains: The impact of mountaintop removal surface coal mining on southern West Virginia communities, 1970--2004
}

\author{
Shirley L. Stewart Burns \\ West Virginia University
}

Follow this and additional works at: https://researchrepository.wvu.edu/etd

\section{Recommended Citation}

Stewart Burns, Shirley L., "Bringing down the mountains: The impact of mountaintop removal surface coal mining on southern West Virginia communities, 1970--2004" (2005). Graduate Theses, Dissertations, and Problem Reports. 2310.

https://researchrepository.wvu.edu/etd/2310

This Dissertation is protected by copyright and/or related rights. It has been brought to you by the The Research Repository @ WVU with permission from the rights-holder(s). You are free to use this Dissertation in any way that is permitted by the copyright and related rights legislation that applies to your use. For other uses you must obtain permission from the rights-holder(s) directly, unless additional rights are indicated by a Creative Commons license in the record and/ or on the work itself. This Dissertation has been accepted for inclusion in WVU Graduate Theses, Dissertations, and Problem Reports collection by an authorized administrator of The Research Repository @ WVU.

For more information, please contact researchrepository@mail.wvu.edu. 
Bringing Down the Mountains:

The Impact of Mountaintop Removal Surface Coal Mining on Southern West Virginia Communities, 1970-2004

Shirley L. Stewart Burns

\author{
Dissertation submitted to the \\ Eberly College of Arts and Sciences \\ at West Virginia University \\ in partial fulfillment of the requirements \\ for the degree of
}

Doctor of Philosophy

in

History

\author{
Ronald L. Lewis, Ph.D., Chair \\ Elizabeth Fones-Wolf, Ph.D. \\ Greg Good, Ph.D. \\ John Hennen, Ph.D. \\ Roger Lohmann, Ph.D. \\ Department of History \\ Morgantown, West Virginia \\ 2005
}

Keywords: Mountaintop removal, strip mining, surface mining, coal mining, coal communities, UMWA, politics, West Virginia, environment, Blair, Kopperston, Sylvester, slurry impoundment, valley fill, Massey, Arch, power, power relationships 


\title{
ABSTRACT \\ BRINGING DOWN THE MOUNTAINS: \\ THE IMPACT OF MOUNTAINTOP REMOVAL SURFACE COAL MINING ON SOUTHERN WEST VIRGINIA COMMUNITIES, 1970-2004
}

\author{
SHIRLEY L. STEWART BURNS
}

While surface mining began in West Virginia during WWI, the practice did not expand until WWII. Used to fuel the war effort, surface mining would become the industry-preferred means of mining coal and gained a permanent place in West Virginia's coal mining industry. Mountaintop removal surface coal mining began on Fayette County, West Virginia's, Bullpush Mountain in 1970. An extreme version of strip mining, during mountaintop removal the tops of mountains are removed via blasting in order to reveal the coal seams below. The last thirty-four years has seen an escalation in this mining method from forty-four permits covering 9,800 acres throughout the 1980s to the granting of permits covering 12,540 acres in a nine-month period in 2002 alone. This increase in mountaintop removal has impacted southern West Virginia not only environmentally, but socially and culturally as well.

The introduction of 20-story draglines in the 1980s allowed for the swifter removal of coal by mountaintop removal. The process enjoyed a great expansion during the 1990s after the Federal Clean Air Act was amended to include a more stringent emissions standard. This increased the demand for southern West Virginia's low sulfur, high volatility coal. Since that time, the process has entered many southern West Virginia coal communities. The UMWA, once staunchly aligned with coal community citizens, continually found itself torn between its Union members working on these sites and the coal community residents opposed to this mining technique. Many coal community residents directly affected by this process created "free spaces" where they could band together in opposition. Many citizens have been plaintiffs in lawsuits against the coal companies operating in their communities, but West Virginia politicians' have vacillated between silence and protectionism. As a direct result of mountaintop removal, the environment of southern West Virginia has suffered as the conversion of continuous hardwood forests have been turned into a fragmented landscape interspersed with grasslands more characteristic of the mid-western United States than Appalachia.

This study focuses on the various impacts this newest form of coal mining has had on coal communities in the nine southernmost West Virginia counties where it takes place, and on the UMWA's declining influence as a traditional counterweight in southern West Virginia. The social, economic, political and environmental consequences are also explored. 
For

My daddy, the late Neely U. Stewart

and

my mom, Cora McKinney Stewart

who gave me strong roots and the courage of my convictions.

Thank you both for telling me that I could be anything that I wanted to be.

And for my brother Rick Stewart

and the rest of my Stewart and McKinney kin;

But most especially for my husband, Matthew Burns

whose support and encouragement has made all the difference, and with whom I am truly blessed;

This work is dedicated to the generations of men in my family who have made their living underground, especially, my daddy;

my grandpaws, the late Gillis Stewart and the late Dave McKinney; and my brother, Allen Stewart, the last of our family to mine these hills; and to my grandmaws who patiently endured, the late Minnie Walker Stewart and the late Maxine Lusk McKinney I cherish all of you. 


\section{Acknowledgements}

A major endeavor such as this could never reach fruition without a long list of people to thank. This is no exception. I wish to thank my entire committee. Ronald Lewis has been a most wonderful adviser and mentor. I am forever thankful that after our first meeting he encouraged me to work with him on a history Ph.D., in spite of my reservations. He is the consummate scholar, and it is obvious that he loves what he does. The time and effort he has spent in useful and constructive criticism of this dissertation is appreciated more than I could ever express. His scholarship, professionalism, and integrity are much admired. A special thanks is in order to Roger Lohmann. After producing a series of research papers on the evolution of black lung legislation for his social work policies class, he took me aside, encouraged me to pursue a Ph.D., and guided me to the history department of West Virginia University and to Ronald Lewis. As an earnest, involved mentor, Dr. Lohmann has to be among the best and deserves much thanks. From the beginning of my doctoral studies, Elizabeth Foneswolf always provided a friendly ear and an open demeanor that, in addition to her excellent teaching skills, made her one of the most approachable - and personable -- scholars I have ever encountered. My love of history was certainly fueled by John Hennen's lively and interesting history courses. I am especially grateful that he traveled from Kentucky to be at my defense. While not knowing me as well as my other committee members, Greg Good's quick enthusiasm for my topic and embracement of my approach was truly appreciated. I thank him for giving me the title idea for chapter six, the environmental chapter. I am convinced that I had the best committee, all wonderful scholars and equally great people. Thanks to every member for all of the encouragement and input. In 
addition to my dissertation committee members, I also offer thanks to Jack McKivigan, who served as a member of my competency examination committee. He is a fantastic teacher who made students want to work harder and question more. I want to also thank Ken Ward, Jr., of the Charleston Gazette and Melody Bragg of the Mine Safety and Health Administration Library in Beaver, West Virginia, for much appreciated and much needed information on United Mine Workers of America membership numbers.

I have always been very fortunate to have many family and friends that have encouraged me from the beginning. My father, long since passed away, was not able to provide the verbal encouragement I had grown so accustomed to receiving from him as a child and young adult; however, you will find him in every line of this endeavor. My father possessed more courage and dignity than anyone I have ever known. His shortened life, ultimately at the hands of the coal mining that sustained us, touched me to my very core and gave my education true meaning. My entire life has been formed and shaped by my childhood and young adult years spent in the small community of Matheny, in the heart of the coalfields of southern West Virginia's Wyoming County. It was here that I developed a passion for people's stories, looking at issues from the "bottom up," and a continued persistence in asking "why" things were the way they appeared to be. It was my father and mother that taught me through example to love and cherish these aged hills and the kin that dwelt within them. Their love of home and place brought them back to these mountains even when doing well in the big city. Throughout all of my schooling, my mother has been an especially vocal cheerleader, always encouraging me and always letting me know that I could do whatever I set my mind to. It was her encouragement alone that got me through many uncertain, lonely days in my 
early graduate work. I am blessed and eternally grateful to have had such wonderful parents. I am also grateful to the Burns' family who quickly accepted me into their family and embraced my dreams as their own.

I thank all of my friends who have provided verbal encouragement to me throughout the years and listened patiently to my numerous mining stories. Three, in particular, were especially helpful in this present process. Louis Orslene helped me focus, created a timeline, and read and provided valuable input on the earliest draft of this endeavor. Christina Bailey, an attorney, read and provided an expert critique of chapter five. Finally, Connie Rice read my earliest draft, provided useful input, and listened to me when I needed it the most.

If there is one individual on earth that I am forever indebted to, it would be my husband Matthew Burns who endured an endless cacophony of mining information, vocal brainstorming, research, writing and rewrites. I am certain that I would not have completed this endeavor without his subtle - and not so subtle - encouragement. His faith in me was stronger than my belief in myself and kept me moving forward. When I felt overwhelmed, he talked me through it and gave me the strength and focus I needed to write "just a little bit more." A better research assistant is not to be found and a more encouraging, supportive partner, I am convinced, does not exist. His willingness to spend hours in the library gleaning statistical information on topics that are of no interest to him is amazing. He read this work from its earliest drafts through the final product. Such endurance is truly remarkable. I am forever grateful to God for bringing us together at the most perfect time in both of our lives. 
My faith in Jesus has continually sustained me throughout these many years and most especially these last few months. I am forever grateful to all that He has given me, and especially to that which through His infinite wisdom He has not.

I know the many struggles I have experienced since leaving Matheny and moving to Morgantown all those many years ago have been the best teachers of all. As a student of academics and of life, I believe it is from the hardest lessons that we learn the most. And it is from these lessons that we become better people, flesh and blood scholars, and not just career academics, always analyzing but never connecting - nor wanting to connect -- to the greater picture. I strive everyday for that continuing connection.

To anyone I may have overlooked, it was not intentional and please know that your kindnesses are appreciated also. 
Table of Contents

Acknowledgements.....................................................

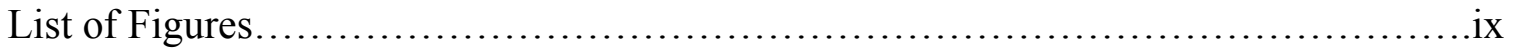

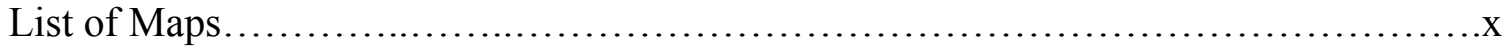

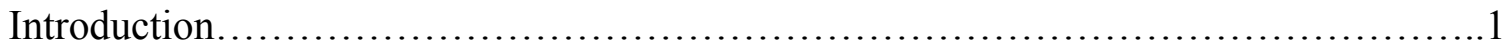

Chapter 1. Making Molehills Out of Mountains: The Rise of Surface Mining in Southern West Virginia.......................................... 16

Chapter 2. Solidarity Forever?: the United Mine Workers of America and Southern West Virginia Coal Communities......................................49

Chapter 3. To Dance with the Devil: The Social Impact of Mountaintop Removal Surface Coal Mining.............................................6 68

Chapter 4. You Scratch Mine, and I'll Scratch Yours: The Political Economy of Coal in Southern West Virginia...............................................101

Chapter 5. Showdown in Charleston: The Judicial System and Mountaintop Removal Surface Coal Mining

Chapter 6. Show Me Where to Put My Fishing Pole: Environmental Impact of Mountaintop Removal Surface Coal Mining............................173

Epilogue Requiem for the Mountains?: Southern West Virginia at a Crossroad.......207

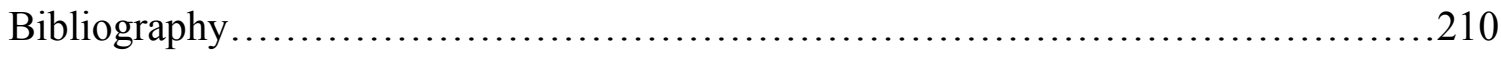

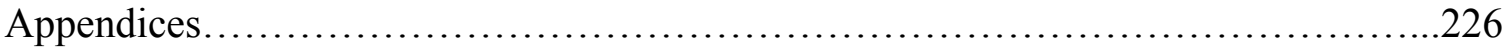




\section{List of Figures}

Figure 1.1.......Boone County Coal Production and Employment, 1971-2003........19

Figure 1.2.......Fayette County Coal Production and Employment, 1971-2003.......22

Figure 1.3.......Kanawha County Coal Production and Employment, 1971-2003......25

Figure 1.4.......Logan County Coal Production and Employment, 1971-2003.........27

Figure 1.5.......McDowell County Coal Production and Employment, 1971-2003......30

Figure 1.6........Mingo County Coal Production and Employment, 1971-2003..........32

Figure 1.7........Nicholas County Coal Production and Employment, 1971-2003.......34

Figure 1.8.......Raleigh County Coal Production and Employment, 1971-2003........36

Figure 1.9.......Wyoming County Coal Production and Employment, 1971-2003......39

Figure 1.10.......Surface Mining Production and Employment in the southern WV

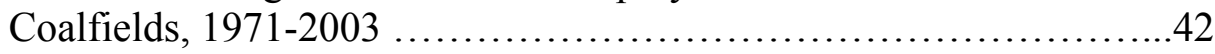

Figure $2.1 \ldots \ldots .$. Nationwide UMWA Membership, 1941-2000....................59

Figure $2.2 \ldots \ldots \ldots$ WV Coal Employment, 1950-2004.............................60

Figure 4.1.......Price Per Ton of WV Coal by Method, 1996-2000..................117

Figure $6.1 \ldots \ldots .$. Classification of Streams by Stream Order...................... 176 


\section{List of Maps}

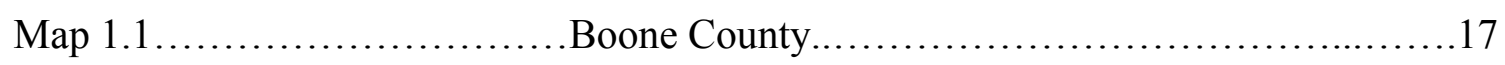

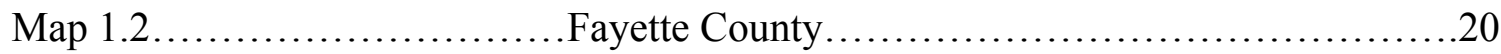

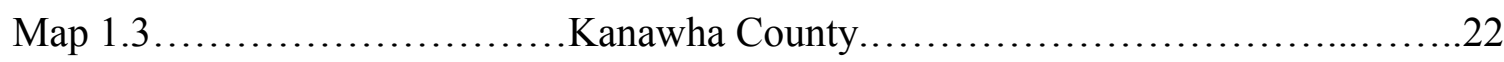

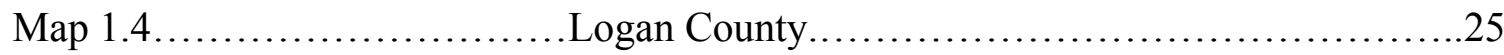

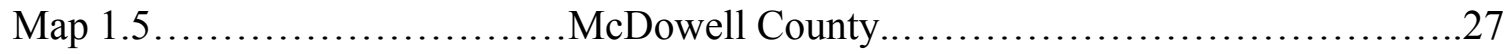

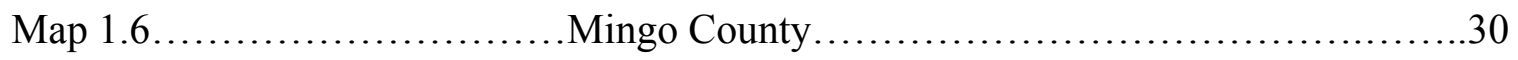

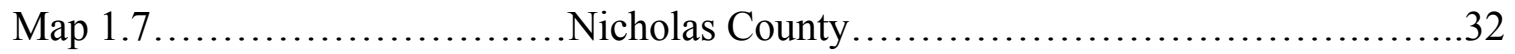

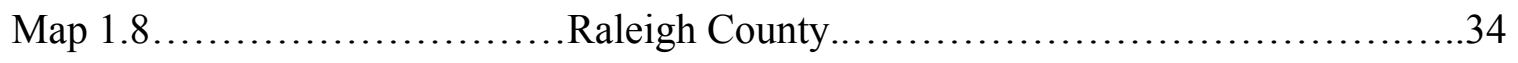

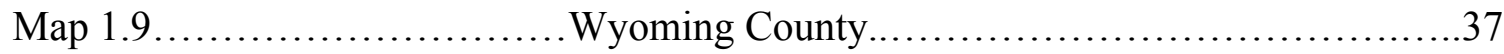




\section{Introduction}

West Virginia has a legacy of preferential treatment of business from all three branches of state government which secured for corporations a dominant role in the state's power structure and a subordinant one for other citizens. The use of legislative tax favors to develop the backcounties of West Virginia during the 1870s and 1880s was hindered by a legal philosophy and system rooted in common law which protected the right of individuals over those of the emerging industrial corporations. If the new state was to take its place among prosperous industrial neighbors as the leaders had imagined, there would have to be a tangible change in the judicial branch of the state. That critical transition occurred in 1889-1890 with the election of judges to the Supreme Court of Appeals who tossed aside the traditional agrarian bias and replaced it with one that privileged industrial uses of land. Now the indirect state subsidies to coal and timber provided by the construction of railroads and business friendly initiatives were complemented by a court which not only upheld these initiatives, but favored industry over individuals on grounds of serving a larger public good. In privileging the corporations, the new court established not only a new legal approach, but also a new power paradigm. ${ }^{1}$

The state's proximity to eastern and Midwestern cities, its temperate climate, and its rich natural resources failed to generate the desired economic growth. The West Virginia Tax Commission's 1884 Report on State Development acknowledged that the state had not experienced the prosperity that it should have given its particular advantages. The report observed that the vast majority of West Virginia's natural resource wealth was being devoured by outside interests who would obtain such resources by any means necessary. ${ }^{2}$ Little attention

\footnotetext{
${ }^{1}$ Ronald Lewis, Transforming the Appalachian Countryside: Railroads, Deforestation, and Social Change in West Virginia, 1880-1920 (Chapel Hill, NC: The University of North Carolina Press, 1998), 104-114.

${ }^{2}$ Ronald Lewis and John Hennen, Jr., eds, West Virginia: Documents in the History of a Rural-Industrial State (Dubuque, IA: Kendall/Hunt Publishing Company, 1996), 2d edition, 168-170.
} 
was given to the idea of economic diversification and the state failed to advance economically as had been expected just after the Civil War. Misguided by the belief that rich natural resources would lead to wealth, the new state leaders failed to realize that they were only creating a single industry resource dependent economy that would ensure the state's peripheral status within the national economy. Natural resource industries were in essence provided a free reign of power to provide economic development in the state, but the state's leaders soon learned that once such power was given it was impossible to wrest it back. One hundred twenty years after the 1884 report that is still the case. Because of the power structure created and solidified by the state's legal and political system, the newest and most expansive form of mining encompassed by mountaintop removal coal mining (MTR) brings prosperity to the mine operators but, predictably, insures that economic prosperity continues to elude the state.

West Virginia, particularly southern West Virginia, exists as a periphery region within the American and global market system. Peripheral regions typically are in larger spatial areas with comparatively smaller populations, smaller cities, and smaller amounts of power with the larger economic and political systems. Core regions have small land areas with larger populations and a concentration of the economic and political power. It is to these areas which the periphery supplies its natural resources. Power resides in the core and resources and wealth from the periphery regions flow in that direction. Like a colony, the periphery supplies raw materials cheaply so that the core can benefit from the production of goods and services for the national and global market. Any attempt to alter this relationship leads to a mobilization coercion by the powerful core against the weaker periphery as the core seeks to maintain its control. 
Sociologist David Walls was one of the first scholars to examine Appalachia as a periphery within the context of advanced capitalist society. He found that Appalachia acts as a supplier of natural resources to the nation, thus functioning as a periphery on the fringe of the dominant, core society controlled by a power elite. ${ }^{3}$ In Who Rules America: Power and Politics, Sociologist G. William Domhoff defines the power elite as those groups "that exercise power on behalf of the owners of all large income-producing properties." This power elite constitutes a national ruling class comprised of members of an identifiable American upper class as well as members of the corporate community which shape policies that directly affect the entire country. ${ }^{4}$ In the southern West Virginia coalfields, this power elite is comprised of the massive coal corporations, organizations with coal-centered agendas (such as the West Virginia Coal Association and Friends of Coal), other large industries with vested economic interests to coal (such as machine manufacturers and distributors), and politicians who support ideas and legislation which benefits the coal industry. Throughout this dissertation, I refer to this group as the "coal interests," or as the "coal alliance." For more than a century West Virginia's southern counties have existed as a periphery region, and its inhabitants have been ruled by a coalcentered power.

The beginning of the twentieth century witnessed the construction of company towns throughout the coal rich valleys of southern West Virginia. Coal companies funded, built, and governed company towns, and maintained control in all aspects of community life. In southern West Virginia where larger towns were scarce and where workers were frequently brought into

\footnotetext{
${ }^{3}$ David S. Walls, "Internal Colony or Internal Periphery: a Critique of Current Models and an alternative Formulation," in Colonialism in Modern America: the Appalachian Case, eds. Helen Matthews Lewis, Linda Johnson, and Donald Askins (Boone, NC: the Appalachian Consortium Press, 1978), 319-340; see also David S. Walls, "Central Appalachia in Advanced Capitalism" (Ph.D. diss., University of Kentucky, 1978).

${ }^{4}$ G. William Domhoff, Who Rules America: Power and Politics (Boston: McGraw-Hill Higher Education, 2002), 95-98.
} 
the area for the explicit purpose of mining coal, the number of miners living in these communities comprised more than 70 percent of the total population. On the surface, coal operators pointed to the housing needs of this largely imported workforce and easily defended the necessity for these towns on grounds of necessity. ${ }^{5}$ The housing agreements that the miners signed guaranteed the coal company control over its employees, also justified as essential to operation. Such authority over the living space of a miner and his family allowed the company to crush any activities that might threaten the company's bottom line. If an employee "got out of line," the employee could be terminated and he and his family would promptly be removed from the company house. ${ }^{6}$ Ruling these towns with an iron fist, the company established a clear power relationship in which the miner (and, in essence, his family) was virtually powerless.

Some scholars have debated the severity of treatment afforded miners in company towns and stressed that miners possessed the option to move from company town to company town thereby limiting some of the control the companies had over workers. ${ }^{7}$ Nevertheless, miners possessed little self-determination and autonomy as they moved from one company town to another, each built on the same power relationship as the previous one. ${ }^{8}$ The company maintained the upper hand in the basic necessity of shelter. These company towns were viewed so negatively that the coal operators themselves often felt pressed to defend the company towns very existence. ${ }^{9}$ Many operators viewed with alarm the turbulence in the region and sought to

\footnotetext{
${ }^{5}$ David Corbin, Life, Work, and Rebellion in the Coal Fields: the Southern West Virginia Miners, 18801922 (Urbana \& Chicago, IL: University of Illinois Press, Illini Books edition, 1981), 8; Ronald D. Eller, Miners, Millhands, and Mountaineers: Industrialization of the Appalachian South, 1880-1930 (Knoxville, TN: University of Tennessee Press, 1982), 162-163

${ }^{6}$ Corbin, Life, Work, and Rebellion, 9.

${ }^{7}$ See for example, Price Fishback, "Did Coal Miners 'Owe Their Souls to the Company Store?"” Theory and Evidence from the Early 1900s," The Journal of Economic History 46 (Dec. 1986), 1011-1029; Crandall Shifflett, Coal Towns: Life, Work, and Culture in Company Towns of Southern Appalachia, 1880-1960 (Knoxville, TN: University of Tennessee Press, 1991); Corbin, Life, Work, and Rebellion, 42.

${ }^{8}$ Corbin, Life, Work, and Rebellion, $9,42$.

${ }^{9}$ Ibid., 9.
} 
extinguish it through welfare capitalism in the form of the "model company town."10 Even after embracing the desirability of improved amenities and fringe benefits found in the "model town," the power structure remained the same with absolute power resting in the hands of the company. These endeavors helped improve the image of coal company towns to outsiders and, in some ways, advanced the quality of life for the towns' inhabitants, but workers did not enjoy true independence. It is this lack of freedom and power over their own lives which inspired many coal miners to support unionization efforts. Power would not be wrested from the hands of the corporations easily, however, and the many, often bloody, battles that followed in order to unionize the southern West Virginia coalfields are well known and well documented. ${ }^{11}$

Company towns as first envisioned and created ceased to exist beyond mid twentieth century when the few company homes that remained in some of the towns were sold to individuals, but numerous, unincorporated communities were left in their place. Even after exiting the company town business, coal companies continued to exercise power over community members who were still economically dependent upon mining. In fact, power became even more concentrated over the course of the twentieth century as ownership and control over the industry became increasingly consolidated into fewer, larger corporations.

With the expansion of the railroads in the late nineteenth and early twentieth centuries came the opening up of the southern West Virginia coalfields. Hundreds of independent coal operators leased land from large absentee land companies with the hopes of cashing in on the coal boom. The glut of coal companies resulted in the overexpansion of the coalfields. Even

\footnotetext{
${ }^{10}$ Ibid., 122-123.

${ }^{11}$ See for example, Robert Shogan, The Battle of Blair Mountain: the Story of America's Largest Labor Uprising (Boulder, CO: Westview Press, 2004); Lon Savage, Thunder in the Mountains (Pittsburgh: Univ. of Pittsburgh Press, 1990); Howard B. Lee, Bloodletting in Appalachia: The Story of West Virginia's Four Major Mine Wars and Other Thrilling Incidents of Its Coal Fields (Morgantown, WV: West Virginia University, 1969); Ken Sullivan, ed., The Goldenseal Book of the West Virginia Mine Wars (Charleston, WV: Pictorial Histories Publishing, 1991).
} 
with a plethora of independent coal operators, large companies continued to dominate the coalfields. Guided by northern bankers, industrialists, and other capitalists, efforts to consolidate the natural resource wealthy land into the hands of a few corporations was accomplished early through the buy-out of these smaller operators by large coal syndicates who would then consolidate several of the small operations into one larger entity. ${ }^{12}$ Early mine operators frequently lived in the mining community, but these larger corporations were owned by absentees. No longer would the operators personally exercise authority of their own, now hired managers became agents of the absentee owners whose corporate offices were far removed from the coal town themselves. ${ }^{13}$ This domination of the coalfields by large, often multinational corporations has accelerated during the twentieth century and persists to present day.

In his study of power relationships in the Clear Fork Valley of Tennessee, John Gaventa examined the power relationships of community members with American Association, LTD., which exercised extensive ownership in the valley. He explored three dimensions of power focusing on public participation in challenging power structures, manipulation of public issues by those with power, and the exploitation and manipulation of information dissemination to ensure beliefs and values preferable to the reigning elite. ${ }^{14}$ Gaventa's study portrayed citizens who were subjected to a company-dominated existence since the erection of the company towns that forged the company-dominated power structure. Rather than accepting defeat, residents often fought back only to find a power structure so complicated that the power source was nearly impossible to locate. The company-dominated power structure ensured the continuation of supremacy and domination for the power elite. The present dissertation also looks at the power

\footnotetext{
${ }^{12}$ Eller, Miners, Millhands, and Mountaineers, 134, 138.

${ }^{13}$ Ibid., 222-223.

${ }^{14}$ John Gaventa, Power and Powerlessness: Quiescence and Rebellion in an Appalachian Valley (Chicago: University of Illinois Press, 1980), 5-20.
} 
relationships between the power elites and the residents of coal communities, and how these intricate relationships continued beyond the stifling of public dissent to the actual forced removal of residents from their homes and communities. With the expansion of MTR, the coal companies no longer needed a substantial workforce. What was needed, though, were the hills and valleys where these people lived, and the land was taken, mostly through coercion, for the "greater good" by the dominant coal interests. As exercised by this power elite, the process of MTR which entered the coalfield communities affected all aspects of life.

Obtaining coal by MTR is a methodical enterprise comprised of several distinct steps. First, trees and vegetation are removed from the area to be mined with the trees typically being leased to a timber company to be logged and sold. In concordance with this initial removal, the operator will either save the topsoil removed or spread it over an existing stripped site. Next, the area is pre-stripped to make a foundation for the dragline, the piece of machinery that is most crucial for MTR operations. The dragline, a large earth-moving piece of machinery, can be as tall as twenty stories high when used in MTR operations. It is this machinery that actually digs and removes the earth and coal. The area is prepared for pre-stripping using shovel loaders and dump trucks. During this phase, access roads are constructed to reach the preliminary operation. This activity continues throughout the life of the MTR operation as area after area is prepared for stripping. The next stage is the actual extraction stage. Overburden, the sub-soil and rocks now exposed, is then drilled, blasted and removed from the area being mined. Hundreds of feet may be removed from the top of the mountain during blasting. The now exposed coal seam is splintered through blasting, and the coal is then hauled away. The overburden is then placed on an already mined area and is compacted and used in re-grading. Any excess overburden remaining after the area is back-filled is placed into a valley fill. Then, reclamation (i.e., 
attempts to restore the area to a useful standard) occurs. This involves using the graded and compacted topsoil on the now stripped site as well as reseeding for vegetation. ${ }^{15}$ A quick and efficient way to obtain coal, there was an upsurge in use of MTR methods during the 1990s.

The MTR method of coal extraction came into widespread use to meet the demand created by the 1970s energy crisis, but in the subsequent decline in demand during the 1980s the method was expanded because it was cheaper for the companies. Demand for southern West Virginia's low-sulfur coal once again exploded with the enactment of the 1990 amendments to the Clean Air Act (CAA). The new amendments would prove auspicious for the West Virginia coal industry, most especially the inclusion of provisions to reduce emission standards of air pollutants. A quick and cheap way to do this was to use low sulfur coal, the same that is found in the southern West Virginia coalfields.

By 1994, the U.S. Department of Energy was anticipating an increase of as much as 24 million tons of coal from the central Appalachian coalfields, much of this from southern West Virginia, as opposed to 12 million from the Powder River Basin in Wyoming. ${ }^{16}$ Coal burning power plants needed a readily available, easily obtainable source of low-sulfur, high volatility coal to meet this new demand. One place they would find it was in the hills of southern West Virginia. The quickest way to obtain this coal was through MTR. Utility companies recognized the importance of obtaining the quality coal as cheaply as possible. American Electric Power (AEP) acknowledged its support of MTR as a way for the company to meet its own need for coal at low prices. In 1999, AEP was the largest purchaser of West Virginia coal, and the majority of

\footnotetext{
${ }^{15}$ Shiva Kolli, "Analyses of Coal Extraction and Spoil Handling Techniques in Mountainous Areas" (MA thesis, West Virginia University, 2001), 26-28.

${ }^{16}$ Ken Ward, Jr., "Clean Air Act may Boost State Coal Sales," Charleston Gazette-Mail, April 12, 1994; "All About Business," Charleston (West Virginia) Daily Mail, April 26, 1994.
} 
that coal was obtained via MTR. It was the low sulfur emissions requirement of the CAA that ensured the utility would continue the purchasing of southern West Virginia coal. ${ }^{17}$

The ultimate goal of the act was to decrease air pollutants, but an unanticipated consequence was the increase in MTR in southern West Virginia and its corollary of fewer and fewer employees. While the area endured decades of environmental problems from previous mining activities, MTR exponentially increased those problems. Once again, the periphery region of southern West Virginia is sacrificed for the benefit of the core region. Some counties were, of course, more affected than others. Boone, Logan, and Kanawha Counties, for instance, produce at least two times as much coal from MTR as other forms of surface mining. Still, other counties such as Wyoming and Raleigh are at the beginning stages of MTR extraction with the total economic and environmental effects yet to be realized. While still an important part of the economy, coal employment is minimal in these areas as increased mechanization leads to fewer and fewer jobs.

The six chapters in this dissertation seek to further the academic discourse on mountaintop removal and its place in the state's political, social, economic, and environmental history. Prior to this dissertation, no historical academic treatment of the topic existed. Mountaintop removal mining is pervasive in nine of the southernmost West Virginia counties: Boone, Fayette, Kanawha, Logan, McDowell, Mingo, Nicholas, Raleigh, and Wyoming. These nine counties are responsible for 67.2 percent of the total production of coal in West Virginia. Surface mining accounted for 82.9 percent of the coal mined in these counties, with 82.3 percent of the surface mined coal coming from MTR. ${ }^{18}$ The 20-story draglines used in MTR cost $\$ 25$

\footnotetext{
${ }^{17}$ George Hohmann, "No One asked AEP's Opinion: Importance of Coal to its Operation Fuels Support of Mountaintop Removal," Charleston Daily Mail, May 27, 1999.

${ }^{18}$ West Virginia Coal Association, Coal Facts 2003 (Charleston, WV: the West Virginia Coal Association, 2003), available from http://friendsofcoal.org/resources/Fact_book.pdf, June 30, 2004.
} 
million or more, and are so large they must be brought in piece by piece and can take years to assemble. ${ }^{19}$ Because of the capital investment required for MTR, only very large companies with vast economic resources can afford to enter the business. In West Virginia, the two leading MTR producers are Arch Coal, Inc., and Massey Energy Company. Faced with the encroachment of this newest mining technique on their communities, many residents of southern West Virginia have found themselves unlikely environmentalists and activists, joining with neighbors directly affected by MTR.

There is a lack of secondary sources pertaining to this topic, and this dissertation relies heavily on primary resources including government studies, reports filed by government departments and committees, legal statutes, lawsuits, newspaper articles, and interviews and conversations with members of coal communities affected by MTR. Although no historical analysis of MTR exists, recent scholarship in other disciplines has emphasized the effects of mountaintop removal surface coal mining on the environment. ${ }^{20}$ Chapter six, which focuses on the environment, incorporates the findings of these studies.

Chapter One includes several graphs that provide a visualization of coal mining production and employment in both surface and underground mining for the nine counties from 1971 - 2003. These graphs clearly illustrate that as mining production has increased, employment has dramatically decreased. Recent trends show that surface mining production continually increased in these areas even while surface employment, on the whole, decreased.

The vast amount of West Virginia coal now being produced by strip mining would have stunned

\footnotetext{
${ }^{19}$ Ken Ward, Jr., "Mining the Mountains: Industry, Critics Look for Mountaintop Removal Alternative: Is There Another Way?" Charleston (West Virginia) Gazette, June 6, 1999.

${ }^{20}$ For a non-exhaustive list of examples, see Jeff Hansbarger, "Mountaintop Removal Mining: An Environmental Impact Assessment (EIA) Scoping Exercise and Impact Assessment of Mining Activities on Aquatic Resources" (MA thesis, West Virginia University, 2000); Frank Ammer, "Population Level Dynamics of Grasshopper Sparrow Populations Breeding on Reclaimed Mountaintop Mines in West Virginia" (PhD diss., West Virginia University, 2003); and Douglass Chamblin, "Small Mammal Communities on a Reclaimed Mountaintop Mine/Valley Fill Landscape in Southern West Virginia” (MA thesis, West Virginia University, 2002).
} 
industry watchers of the early twentieth century. While entering the state during WWI, it remained a cursory mining technique until improvements in both equipment and road access along with increased demand during WWII guaranteed it a place in the state's mining industry. While this highly productive extraction method encountered some obstacles during its tenure, including attempts to have it banned, it has not only endured but flourished. The importance of this evolution, and how it has allowed for the acceptance of present day MTR operations, is also examined in this chapter.

Chapter Two considers the influence of the United Mine Workers of America (UMWA) in communities where MTR occurs. In the early twentieth century, the UMWA struggled to gain successful entrance into the southern West Virginia coalfields. Once entrenched in the region, union membership in the southern coalfields continually climbed. During the last decades of the twentieth century, however, this past stronghold of the union has witnessed such a large decline in membership that two districts (District 17 and District 29) were combined into one. ${ }^{21}$ While its membership dwindled, the union attempted alternative ways to replenish its base, such as organizing strip mine (including MTR) workers. The new additions to membership placed it in a precarious position between representing surface and underground members who often have opposing priorities. In addition, its influence within the coal communities themselves has suffered. This transformation of purpose and influence in southern West Virginia coal communities affected by MTR is discussed in Chapter Two.

As MTR emerged as a major method of extraction, its effect upon communities became evermore apparent. Chapter Three examines the various impacts this mining activity has had on the communities where it occurs. MTR compelled residents to confront the consequences of this

${ }^{21}$ Edward Peeks, “New UMW Chief has Hard Job," Charleston Gazette, May 21, 2001. 
mining practice, and the age-old industry argument of jobs versus the environment. While residents were forced to deal with nuisances of noise and dust pollution, they also faced the dangers of highways choked by large trucks, and coal waste impoundments which loomed over their communities. Employees of these MTR sites juxtaposed their need for jobs against residents' concerns and, not surprisingly, concluded that their need for employment surpassed community members' complaints regarding safety and environmental degradation. Most MTR workers do not live in the communities where this mining takes place. People on both sides of the issue are passionate in their stances on MTR and agreement is rarely found between the two factions. Some residents have formed community organizations to combat what they see as the coal company infringing upon their rights. This chapter examines some of the communities affected by MTR, and their struggle to maintain a semblance of self-determination where they live.

Chapter Four analyzes the intricate relationship of politics, economics and the coal industry in the state. The state's earliest politicians acted as advertising agents for the natural resource development of the state, and were instrumental in crafting industry-friendly legislation which provided the foundation for natural resource domination in the southern coalfields. Politicians have allied with the coal companies, and many were employed by the industry both before and after their political careers. The lack of economic diversification has severe repercussions for the southern coal counties. Such intense dependence upon one industry has entrenched the counties in a subservient position. Coal jobs have dwindled in these areas and no other industries have adequately replaced them. Outmigration has accompanied the decline in jobs as the youngest and most mobile of inhabitants continue to leave the area to find work. The result has been a depleted tax base, which adversely affects residents in these areas many of 
whom are the elderly and/or disabled. Social welfare programs in these counties (including the nine counties examined in this study) are the highest in Central Appalachia. ${ }^{22}$ Even with the problems associated with MTR, it continues to be embraced by West Virginia's state and federal politicians. State politicians have been vocal in their support of MTR operations, going so far as to implore then President William Clinton not to release an early draft of an environmental impact study on the effects of MTR. For their part, West Virginia's congressional delegation has taken firm stands in support of the practice and against stiffer regulation. In this they have been abetted by the judicial system whose role will be examined in Chapter Five.

In October 1999, a rift occurred in what many viewed as a nearly impenetrable hold of industry over the judicial system. In a surprising decision, conservative Republican Judge Charles Haden, II, ruled that filling in perennial and intermittent steams with valley fills was illegal. Bragg v. Robertson, as the case would become known, was the first high profile case in a series of legal challenges to MTR. Chapter Five explores some of the most significant of the lawsuits involving MTR, why the lawsuits occurred, and their outcomes. While Haden and others on the state level would continue to rule in favor of the plaintiffs, the Fourth U.S. District Court of Appeals would just as quickly overturn these rulings. Known as the most conservative court in the nation, it would not disappoint supporters of MTR as time and again appeals regarding MTR which came before it were overturned.

Regardless of the outcomes of these cases, it is notable that so many everyday citizens had decided to take legal action against the corporations. This blatant challenge to the power structure is important, especially in understanding the prevailing power relationships in these coal communities. In the face of probable reversal of federal cases it would be understandable if

\footnotetext{
${ }^{22}$ Center for Business and Economic Research, A Study on the Current Economic Impacts of the Appalachian Coal Industry and its Future in the Region: Final Report (Louisville, KY: University of Kentucky, March 27, 2001), 87.
} 
people stopped pursuing these legal challenges against the coal companies. However, that is not what has happened. Instead, legal challenges brought forth by individuals, community, and environmental groups have not been deterred by the Fourth Circuit Court's decisions, and new cases are continually filed in county and state courts. Plaintiffs continue to challenge the MTR process and, in essence, the power structure that allows the activity to occur. On the state level, the most successful cases have been those concerning the effect of MTR on the environment. The final chapter, Chapter Six, details these environmental effects on southern West Virginia's landscape.

At first glance, the most noticeable feature of MTR is the amount of acreage that has been disturbed by these operations. In a ten-year period spanning from 1992-2002, more than 90,000 acres of the southern West Virginia coalfields were permitted for MTR mining activities. ${ }^{23}$ One of the most obvious effects occurs in watersheds. An example is the increased sedimentation that takes place as fills are placed in streams and quickens soil erosion. ${ }^{24}$ This excessive sedimentation leads to a drop in the overall productivity of the stream and may result in a decrease in lower order organisms that higher level organisms prey upon. Essentially, the natural order of life in these streams is severely altered or lost. Wildlife is also affected by MTR operations. Small mammals such as a variety of species of mice continue to thrive on reclaimed MTR sites, but larger mammals such as the black bear do not fare so well. This is most likely due to the change that a reclaimed mine site goes through. Before MTR the area was largely hardwood forests, but after reclamation it resembles midwestern grasslands. MTR is responsible

\footnotetext{
${ }^{23}$ United States Environmental Protection Agency, Draft Environmental Impact Study (DEIS), Cumulative Impact Study, Appendix I, December 2002 (Washington, DC: United States Environmental Protection Agency), 4546.

${ }^{24}$ Kentucky Department for Environmental Protection, A Macroinvertebrate Bioassessment Index for Headwater Streams of the Eastern Coalfield Region, KY (Frankfort, KY: Kentucky Department for Environmental Protection, Division of Water, Water Quality Branch, 2002), 25.
} 
for numerous environmental impacts such as these and this chapter explores many of the consequences. Due to the technical nature of Chapter Six, the various aspects of the environmental impact of MTR have been divided into categories and subcategories.

By the time MTR entered West Virginia in 1970, the state was firmly entrenched as a rural-industrial state with the southern coalfield region dependent on coal extraction for its economic survival. Mountaintop removal surface mining has had a massive impact on communities in southern West Virginia. Counties have witnessed a decrease in employment and an increase in environmental degradation. As these communities continue to dwindle into ghost towns, it is important to document their existence. Ironically, these communities which once flourished because of coal mining are now being destroyed by the same industry that created and sustained them. It is hoped that this work will provide a foundation for future scholars examining the impact of this newest form of mining on the people and the environment of the West Virginia, and Appalachian, coalfields. 


\section{Chapter One: \\ Making Molehills Out of Mountains: \\ The Rise of Surface Mining in Southern West Virginia}

"I would feel more optimistic about a bright future for man if he spent less time proving that he can outwit Nature and more time tasting her sweetness and respecting her seniority." E.B. White ${ }^{1}$

Development in the backcounties of West Virginia occurred at a slower pace than the more populated areas and was mainly comprised of natural resource extraction. The repercussions of a single industry economy continues its influence as job choices are still minimal in these areas. Connection to outside markets came early for the southern coalfields territory and it was the region's initial connection to the world markets that led to the speculation of the area and to the vast numbers of absentee landowners that would pervade the region, gobbling up the natural resource wealthy land. ${ }^{2}$ The legacy of these acquisitions resounds today when more than two-thirds of the state's non-public land is overwhelmingly owned by absentee landowners. ${ }^{3}$ In the nine county sub-region included in this study, all but one county (Kanawha) are overwhelmingly owned by absentee landowners with more than 50 percent of acreage controlled by outside interests. One county, Wyoming, has outside landownership that exceeds

${ }^{1}$ E.B. White, Essays of E.B. White from the essay "Coon Tree" (New York: First Perennial Classics, division of Harper Collins, 1999), 47.

${ }^{2}$ Wilma Dunaway, The First American Frontier: Transition to Capitalism in Southern Appalachia, 17001860 (Chapel Hill: the University of North Carolina Press, 1996), 54-66, 192-193; Ronald D. Eller, Miners, Millhands, and Mountaineers: Industrialization of the Appalachian South, 1880-1930 (Knoxville, TN: The University of Tennessee Press, 1982), xxi, 50-52. Identification, mapping, and purchasing of resources occurred as early as the eighteenth century, prior to the intense natural resource exploitation that would accompany the industrial transition in the mountains. Still, absentee holdings could not be fully exploited until the railroads entered the treacherous, coal rich southern West Virginia territories at varying times for each county during the late nineteenth early twentieth centuries.

${ }^{3}$ Tom Miller, "Absentees Dominate Land Ownership," in Who Owns West Virginia?, reprinted from the Herald Adviser and the Herald-Dispatch (Huntington, WV, 1974), 1-3. 
more than 100 percent as a duplication of mineral and surface rights surpasses the total acreage in the county itself. ${ }^{4}$

With such a large amount of land held by outside interests, economic diversification is nearly non-existent in the majority of the nine-county sub-region. Direct coal related employment continues to decline and this unemployment is accompanied by an exodus of residents from the region. The following demographic synopses for each county provide brief statistical information on the counties including formation, initial mining tonnage numbers, coal tonnage and employment from the introduction of MTR in the 1970s-2003, as well as recent MTR mining trends in each county. Graphs depicting underground and surface production and employment for each county are also included. This demographic information is followed by an overview of the evolution of strip mining in West Virginia.

\section{Boone}

\section{Map 1.1}

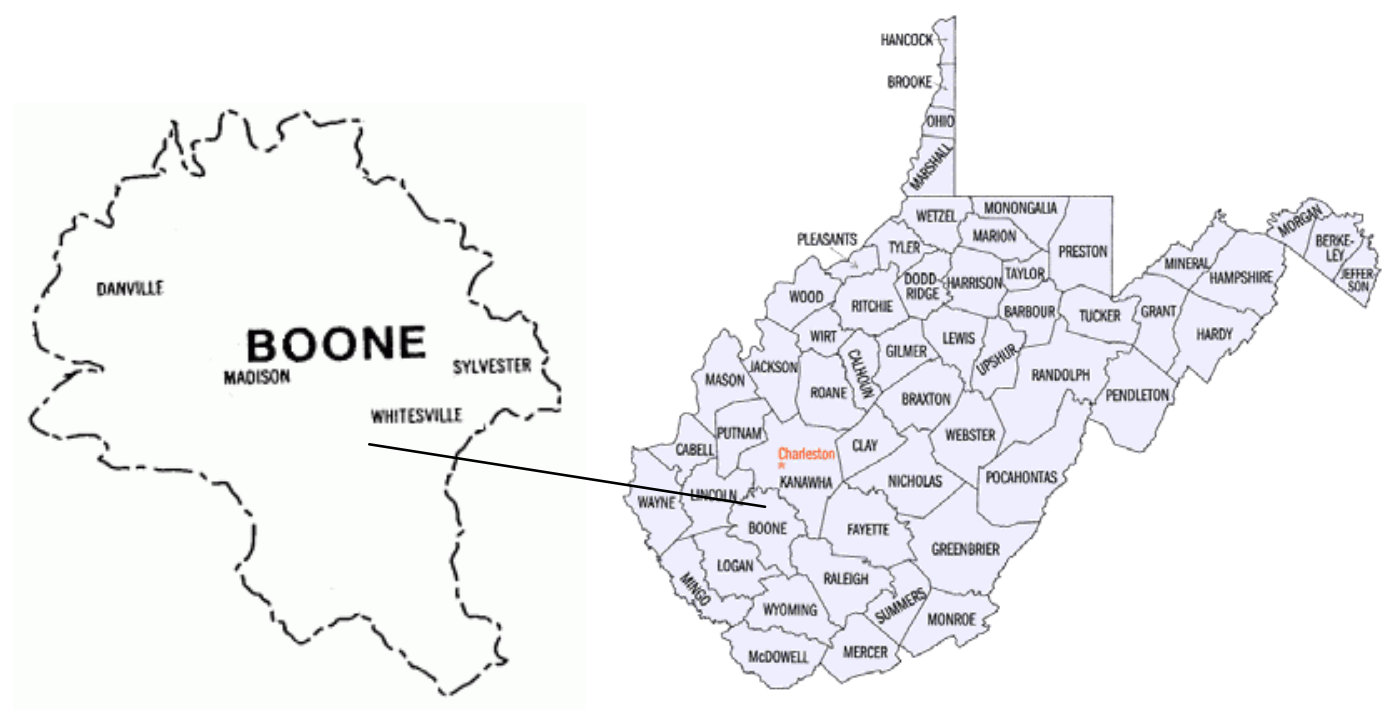

\footnotetext{
${ }^{4}$ Ibid., 5-6.
} 
Boone County, West Virginia, [Map 1.1] was formed on March 11, 1847, from parts of Cabell, Kanawha and Logan Counties (Virginia), and is 503 square miles in size. ${ }^{5}$ In the 1850 census, farming outdistanced other occupations by an approximately two to one ratio. ${ }^{6}$ In 1846 , one year before Boone became a separate county, the first coal was mined within its borders. Mining began in earnest, however, when the first railroad opened in the area in 1909; by 1910 coal tonnage had increased from 3,865 tons to 56,534 tons. $^{7}$

In 1970, 2,714 residents of Boone made their living through coal mining. ${ }^{8}$ The county saw a steady rise in those numbers throughout the 1970s and into the early 1980s before seeing a gradual decrease that would continue through the remaining 1980s. ${ }^{9}$ From 1990 to 2003, mining employment in the county has been a veritable roller coaster. From 2002 to 2003, the county saw an increase of 142 coal jobs from 3,114 in 2002 to 3,256 jobs in 2003. ${ }^{10}$ [Please see Figure 1.1 for an illustration of employment and production trends for Boone County.] In 2003, total employment for the county was 7,682 jobs, and coal represented 42.3 percent of the total employment. ${ }^{11}$ Boone County ranked number one in direct coal employment for West Virginia. In 2002 , the County produced $31,817,818$ tons of coal with $12,103,183$ tons of that coal (or 38

\footnotetext{
${ }^{5}$ Boone County Genealogical Society, Boone County, West Virginia, History, 1990. (Madison, WV: Boone County Genealogical Society, 1990), 8.

${ }^{6}$ Lorna Workman, Boone County, Virginia (now West Virginia), 1850 U.S. Census, available from $\mathrm{ftp}: / / \mathrm{ftp} . u s-c e n s u s . o r g / p u b /$ usgenweb/census/va/boone/1850/1850cens.txt, July 11, 2004.

${ }^{7}$ Boone County History, 15.

${ }^{8}$ Center for Economic Research, Boone County, WV, County Data (Morgantown, WV: West Virginia University, July 1991).

${ }_{9}^{9}$ West Virginia Bureau of Employment Programs, Employment and Unemployment Data (Charleston, WV: Bureau of Employment Programs, Research, Information and Analysis, 2004) available from: http://www.state.wv.us/scripts/bep/lmi/cntydata.cfm, July 11, 2004. Select Boone, then 1980-89, 1990-1999 information.

${ }^{10}$ West Virginia Bureau of Employment Programs, Employment and Unemployment Data (Charleston, WV: Bureau of Employment Programs, Research, Information and Analysis, 2004) available from: http://www.state.wv.us/bep/lmi/ew2002/ew02x005.htm, http://www.state.wv.us/bep/lmi/ew2003/ew03x005.htm, June 30, 2004.

${ }^{11}$ Ibid., http://www.state.wv.us/bep/lmi/ew2003/ew03x005.htm
} 
percent) obtained via mountaintop removal. ${ }^{12}$ The 2000 Census registered the population of Boone County at 25,535 and noted a median income of $\$ 25,669 .{ }^{13}$ The five largest employers in the county as of December 2003 were Boone County Board of Education, Independence Coal Company, Inc., Eastern Associated Coal Company, Elk Run Coal Company, and Hobet Mining, Inc. Of the nine counties, Boone has more top five employers that are coal companies than any of the other eight counties. The county has a five-year unemployment rate of 8.68 percent. ${ }^{14}$ In 1999, 22 percent of Boone County residents lived in poverty. ${ }^{15}$

\section{Figure 1.1}

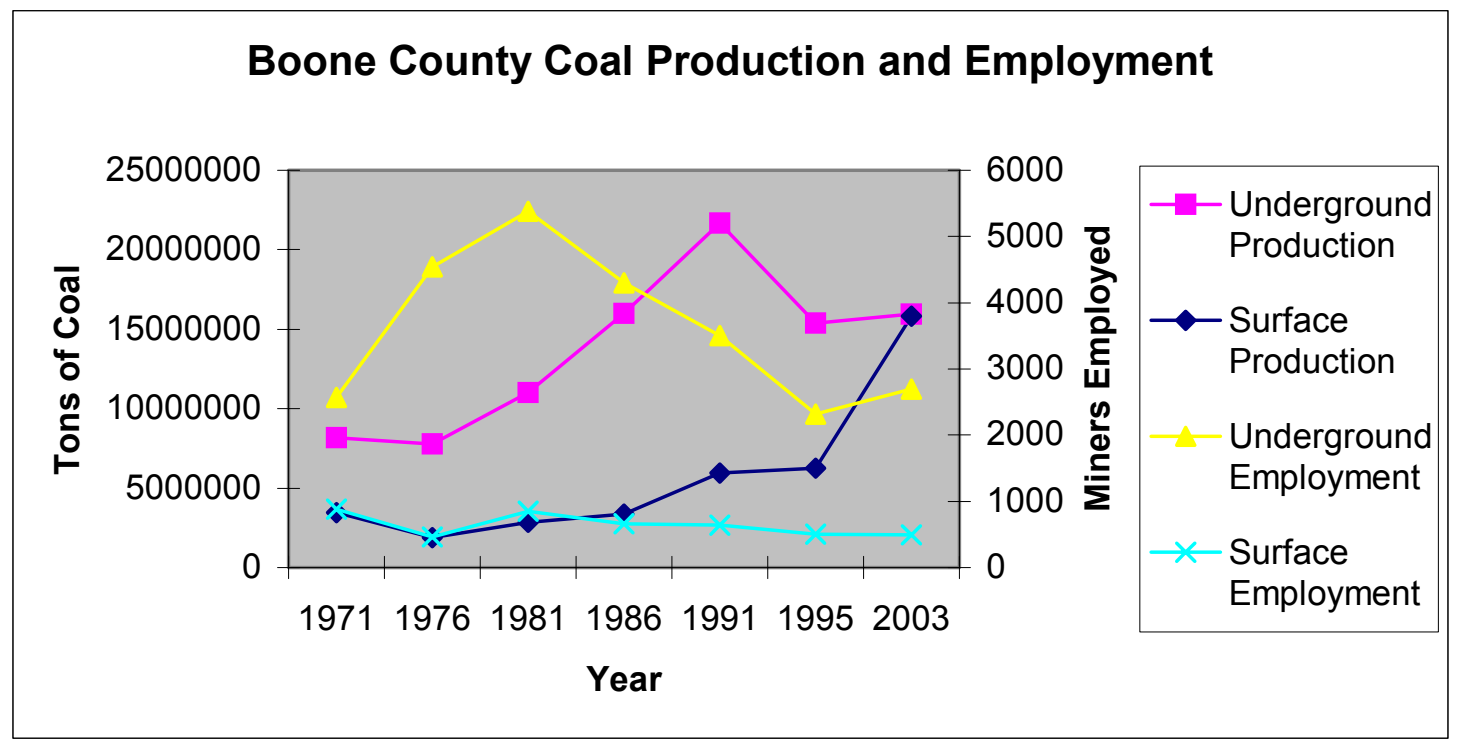

Source: Statistics from WV Coal Facts 1971-2003 and West Virginia Bureau of Employment Programs, 2003. Graph prepared by author.

\footnotetext{
${ }^{12}$ West Virginia Coal Association, Coal Facts 2003 (Charleston, WV: the West Virginia Coal Association, 2003), 9-10.

${ }^{13}$ U.S. Bureau of the Census, Population, 2000.

${ }^{14}$ West Virginia Bureau of Employment Programs, Employment and Unemployment Data (Charleston, WV: Bureau of Employment Programs, Research, Information and Analysis, 2004) available from: http://www.state.wv.us/bep/lmi/LATEEMP.HTM, July 11, 2004. Statistics gathered by adding and dividing from the various appropriate searches per each county.

${ }^{15}$ U.S. Bureau of the Census, West Virginia Quick Facts available from: http://quickfacts.census.gov/qfd/states/54/54005.html, June 30, 2004. Statistics gathered by adding and dividing from the various appropriate searches per each county.
} 


\section{Fayette}

Map 1.2

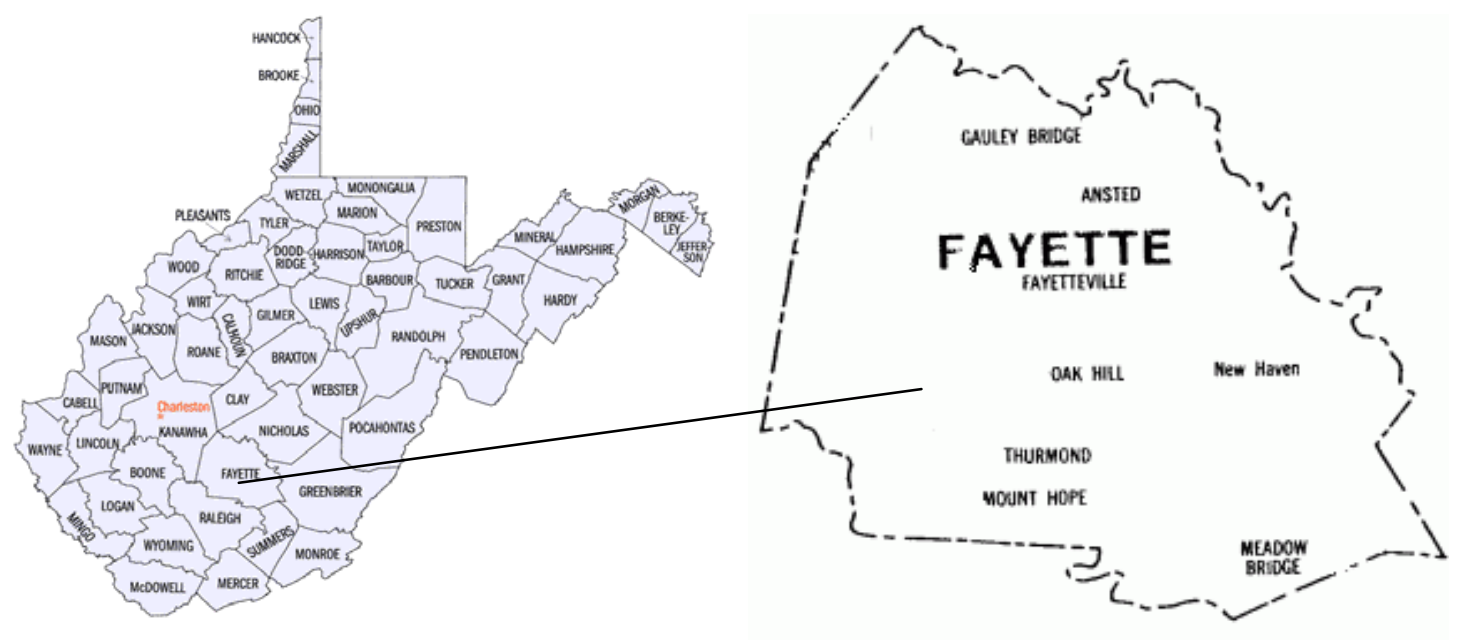

Fayette County, West Virginia, [Map 1.2] was formed on February 28, 1831 from parts of Greenbrier, Kanawha, Logan and Nicholas Counties (Virginia), and is 664 square miles in size. ${ }^{16}$ Unlike the other counties, farming was secondary to hunting in the county and most of the white settlers identified themselves as hunters rather than farmers, and during its early years there were few large farms in the county. ${ }^{17}$ Coal was first mined in the county in 1849. The county was number one in coal production for many years as the most southern coal counties awaited the coming of the railroads which would effectively open their coalfields. In 1893-94, the Gauley Branch of the $\mathrm{C} \& \mathrm{O}$ was completed for the transportation of both coal and lumber. In 1894, the Loup Creek Branch of the C\&O opened from Thurmond along Dunloup Creek to Price Hill. ${ }^{18}$ While still producing coal, the county would mine less and less of the state's net coal production as the most southern coal counties became major producers in the state's coal industry.

\footnotetext{
${ }^{16}$ History of Fayette County, West Virginia, 1993 (Oak Hill, WV: Fayette County Chamber of Commerce, 1993), 147.

${ }^{17}$ Ibid., 302.

${ }^{18}$ Ibid., 245-246.
} 
In 1970, 2,182 residents of Fayette County made their living through coal mining. ${ }^{19}$ The County saw a temporary increase in mining during the 1970s coal boom, but it was short lived, and by 1989 , only 805 people in Fayette County earned a living mining coal. ${ }^{20}$ Employment in coal has steadily decreased and by the end of 2003, only 431 coal mining jobs remained in the county (down from 458 mining jobs in 2002). [Please see Figure 1.2 for an illustration of employment and production trends for Fayette County.] In 2003, total employment for the county was 12,082 jobs, and coal represented only 6.6 percent of the total employment. ${ }^{21}$ Nevertheless, Fayette ranks thirteenth among the state's twenty-six coal producing counties. In 2002, Fayette County coal mines produced 3,955,524 tons of coal with 2,413,296 tons of that coal (or 61 percent) obtained via MTR. ${ }^{22}$ The 2000 Census registered the population of the County at 47,579 and noted a median income of $\$ 24,788 .^{23}$ The five largest employers in the county as of December 2003 were Fayette County Board of Education, Global Contact Services, LLC, West Virginia University, Mt. Olive Correctional Complex, and Elkam Metals, Inc. The county has a five-year unemployment rate of 8.42 percent. $^{24}$ In 1999, 21.7 percent of County residents lived in poverty. ${ }^{25}$

${ }^{19}$ Center for Economic Research, Fayette County, WV, County Data (Morgantown, WV: West Virginia University, July 1991).

${ }^{20}$ West Virginia Bureau of Employment Programs, Employment and Unemployment Data (Charleston, WV: Bureau of Employment Programs, Research, Information and Analysis, 2004) available from: http://www.state.wv.us/bep/lmi/LATEEMP.HTM, July 11, 2004. Select Fayette, then 1980-89, 1990-1999 information.

${ }^{21}$ West Virginia Bureau of Employment Programs. Employment and Unemployment Data. (Charleston, WV: Bureau of Employment Programs, Research, Information and Analysis, 2004) available from: http://www.state.wv.us/bep/lmi/ew2003/ew03x019.htm, http://www.state.wv.us/bep/lmi/ew2002/ew02x019.htm, July 11, 2004.

${ }^{22}$ Coal Facts 2003, 9-10.

${ }^{23}$ U.S. Bureau of the Census, Population, 2000.

${ }^{24}$ West Virginia Bureau of Employment Programs, Employment and Unemployment Data (Charleston, WV: Bureau of Employment Programs, Research, Information and Analysis, 2004) available from: http://www.state.wv.us/bep/lmi/LATEEMP.HTM, July 11, 2004. Statistics gathered by adding and dividing from the various appropriate searches per each county.

${ }^{25}$ U.S. Bureau of the Census, West Virginia Quick Facts available from: http://quickfacts.census.gov/qfd/states/54/54019.html, July 12, 2004. 
Figure 1.2

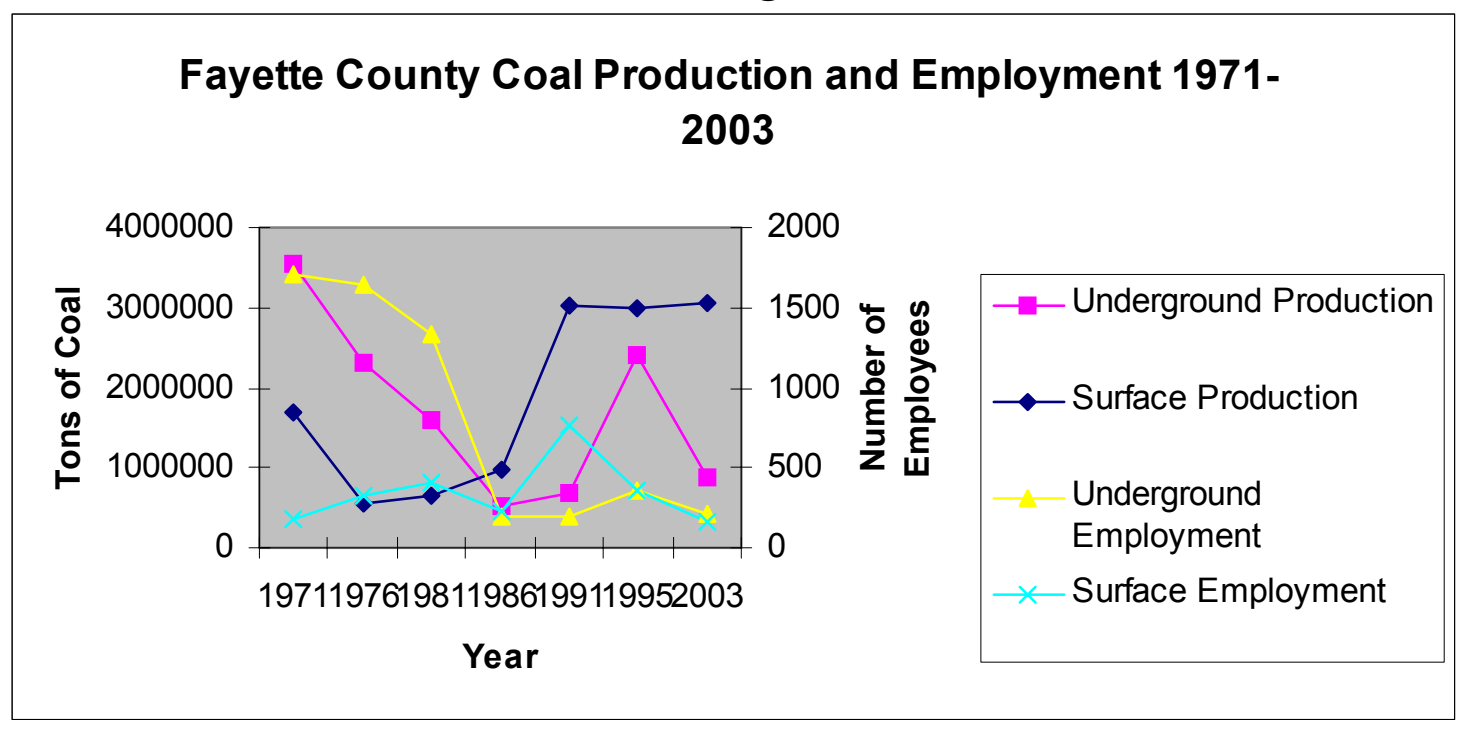

Source: Statistics from WV Coal Facts 1971-2003 and West Virginia Bureau of Employment Programs, 2003. Graph prepared by author.

\section{Kanawha}

Map 1.3

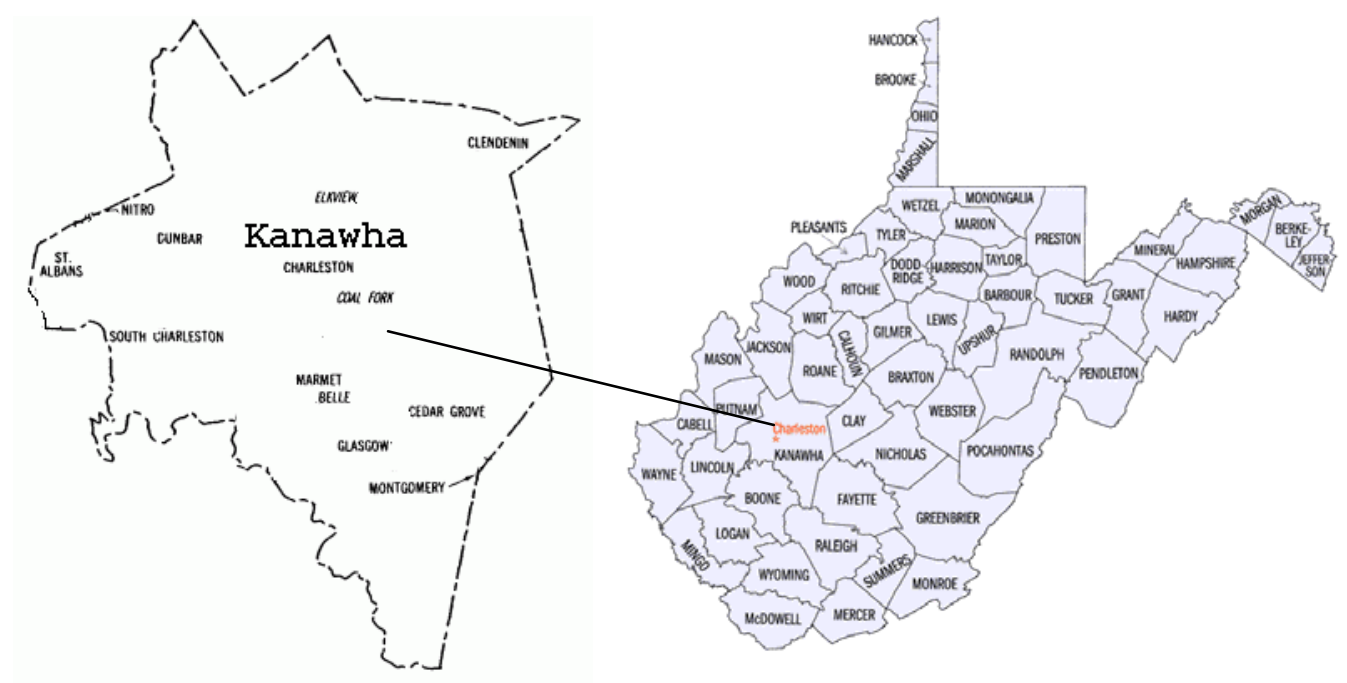

Kanawha County, West Virginia, [Map 1.3] was formed in 1789 from parts of Greenbrier and Montgomery Counties (Virginia), and is 903 square miles in size. ${ }^{26}$ Its principality,

${ }^{26}$ V.B. Harris, Great Kanawha: An Historical Outline (Charleston, WV: Kanawha County Court, for the bicentennial celebration, 1976), 65-67; U.S. Bureau of the Census, West Virginia Quick Facts available from: http://quickfacts.census.gov/qfd/states/54/54039.html, July 11, 2004. 
Charleston, became the permanent state capital of West Virginia in $1885 .^{27}$ Its location on the Kanawha River and other major water channels made it a desirable destination for not only agricultural ventures, but for industrial ventures as well. In the mid-nineteenth century, Kanawha county coal was used exclusively in the salt boiling process for salt manufacturing in the Kanawha Valley. ${ }^{28}$ The use of the coal allowed for the improvement of the evaporation process used in salt manufacturing and, in effect, aided in "a greater quantity of a higher-quality product at a cheaper price.”29 By 1850, cannel-coal mines were shipping their products by waterway. ${ }^{30}$ Railroads fixed firmly in the Valley by the late 1860 s and ushered in a boom-time for the timber and coal industries. ${ }^{31}$

In 1970, 3,861 residents of Kanawha County made their living through coal mining. ${ }^{32}$ By 2003, only 1,334 Kanawha County residents made their living through the coal mining industry, down from 1,398 in $2002 .{ }^{33} \quad$ [Please see Figure 1.3 for an illustration of employment and production trends for Kanawha County.] Still, in 2002 the County produced 16,021,253 tons of coal with 6,081,726 (or 37.9 percent) of that coal coming from MTR operations. ${ }^{34}$ Total employment for the county was 108,696 and coal represented only 1 percent of total Kanawha

\footnotetext{
${ }^{27}$ Otis Rice, West Virginia: the State and its People (Parsons, WV: McClain Printing Company, 1972), 215-216

${ }^{28}$ Otis Rice, "Coal Mining in the Kanawha Valley to 1861: A View of Industrialization in the Old South," The Journal of Southern History 31 (November 1965): 393-416.

${ }^{29}$ John E. Stealey, III, The Antebellum Kanawha Salt Business \& Western Markets (Lexington, KY: University Press of Kentucky, 1993), 52-56.

${ }^{30}$ Ibid., 399.

${ }^{31}$ Ibid., 197.

${ }^{32}$ Center for Economic Research, Kanawha County, WV, County Data (Morgantown, WV: West Virginia University, July 1991).

${ }^{33}$ West Virginia Bureau of Employment Programs, Employment and Unemployment Data. (Charleston, WV: Bureau of Employment Programs, Research, Information and Analysis, 2004), available from: http://www.state.wv.us/bep/lmi/ew2003/ew03x039.htm, http:/www.state.wv.us/bep/lmi/ew2002/ew02x039.htm, July 11, 2004.

${ }^{34}$ Coal Facts 2003, 10.
} 
County employment. ${ }^{35}$ Yet, Kanawha County is fourth in total direct coal employment, and third in total coal production. Mountaintop removal mining produces the largest amount of coal from Kanawha County mines. ${ }^{36}$

These figures provide a good example of the effect that surface mining, particularly MTR, has had upon overall coal mining employment. Mountaintop removal mining does not take nearly the manpower that traditional, underground mining takes and even though Kanawha ranks fourth in total coal county employment, coal companies are not providing a substantial number of employment opportunities for Kanawha County residents. These numbers also represent a diversified economy which diminishes dependency upon coal employment. The 2000 census registered the population for the capital county as 200,073 and listed a median income of $\$ 33,766 .^{37}$ The five largest employers in the county as of December 2003 were Charleston Area Medical Center, Kanawha County Board of Education, Minneapolis Postal Data Center, Herbert J. Thomas Memorial Hospital Association, Wal-Mart Associates, Inc. The county has a five-year unemployment rate of $4.54 .^{38}$ In $1999,14.4$ percent of County residents lived in poverty. ${ }^{39}$ As home to the state capital, Kanawha County has a far more diversified economy than the other eight counties and as such has much more positive countywide statistics.

\footnotetext{
${ }^{35}$ West Virginia Bureau of Employment Programs, Employment and Unemployment Data. (Charleston, WV: Bureau of Employment Programs, Research, Information and Analysis, 2004), available from: http://www.state.wv.us/bep/lmi/ew2003/ew03x039.htm, July 11, 2004.

${ }^{36}$ Coal Facts 2003, 9-10.

${ }^{37}$ U.S. Bureau of the Census, Population, 2000.

${ }^{38}$ West Virginia Bureau of Employment Programs, Employment and Unemployment Data (Charleston, WV: Bureau of Employment Programs, Research, Information and Analysis, 2004), available from: http://www.state.wv.us/bep/lmi/LATEEMP.HTM, July 11, 2004. Statistics gathered by adding and dividing from the various appropriate searches per each county.

${ }^{39}$ U.S. Bureau of the Census, West Virginia Quick Facts available from: http://quickfacts.census.gov/qfd/states/54/54039.html, July 11, 2004.
} 
Figure 1.3

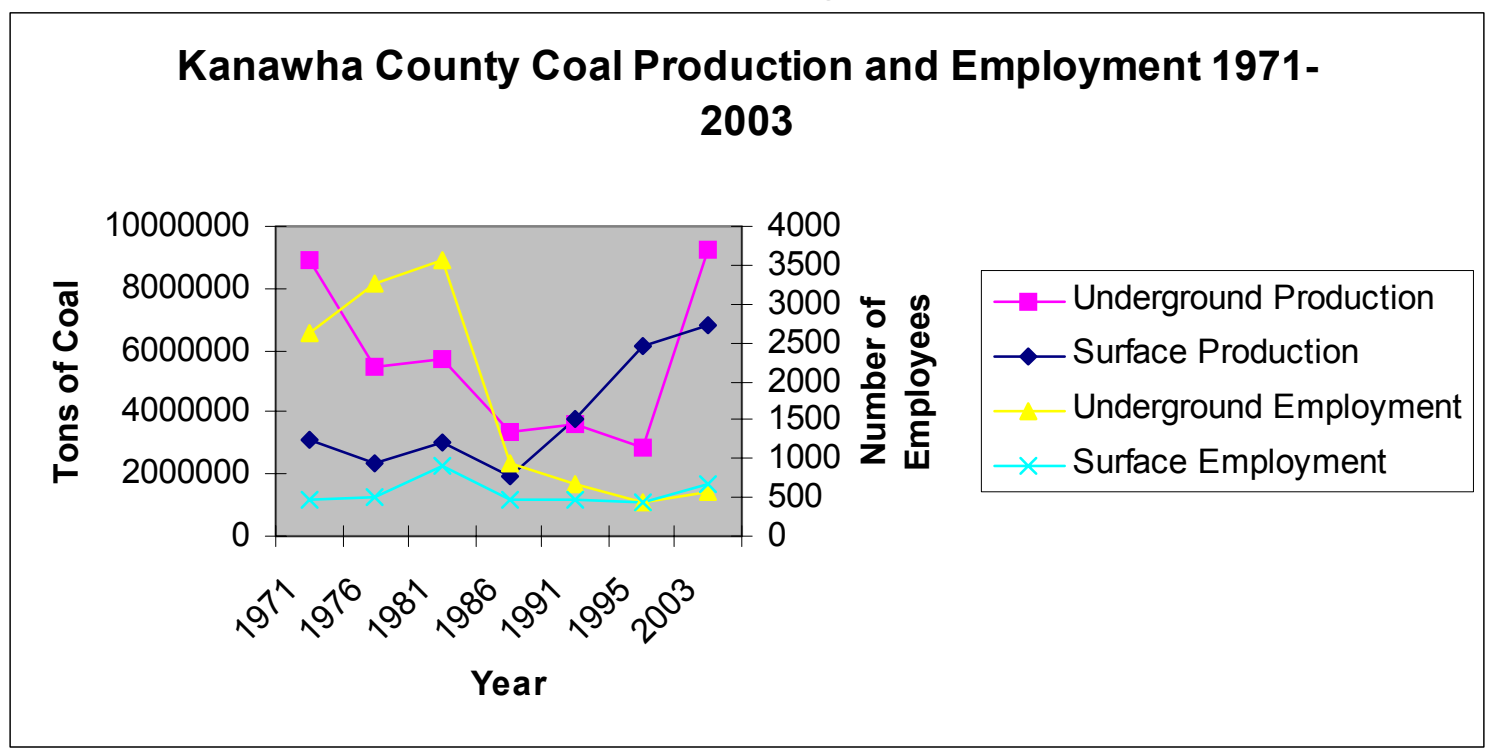

Source: Statistics from WV Coal Facts 1971-2003 and West Virginia Bureau of Employment Programs, 2003. Graph prepared by author.

\section{Logan}

Map 1.4

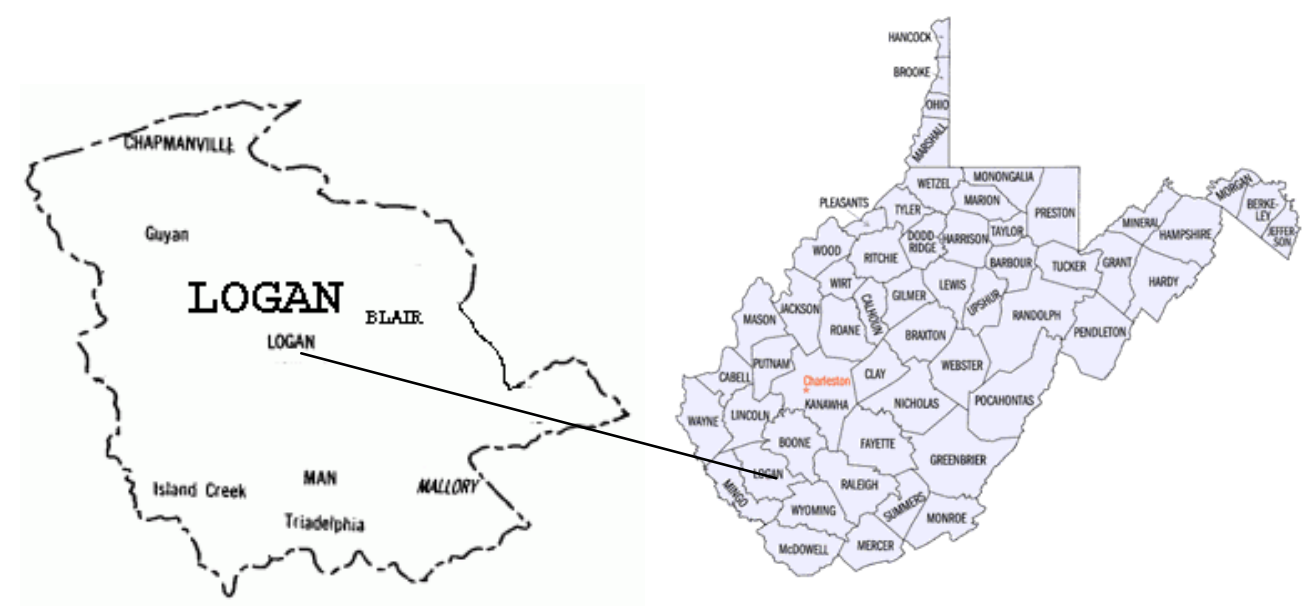

Logan County, West Virginia, [Map 1.4] was formed on January 12, 1824, from parts of Cabell, Giles, Kanawha and Tazewell Counties (Virginia), and is 454 square miles. $^{40}$ Coal was first mined in the county in 1904 when the C\&O Railroad made its way to Logan. ${ }^{41}$

${ }^{40}$ Walter Thurmond, The Logan Coal Field of West Virginia (Morgantown, WV: West Virginia University Library, 1964), 17-18; U.S. Bureau of the Census, West Virginia Quick Facts available from: http://quickfacts.census.gov/qfd/states/54/54045.html, July 12, 2004.

${ }^{41}$ Thurmond, 25, 53. 
In 1970, 4,792 residents of Logan were employed in coal mining. ${ }^{42}$ As of 2003, 1,195 people were directly employed by the coal industry (down from 1,278 the previous year). [Please see Figure 1.4 illustration of employment and production trends for Logan County.] Total employment for the county was 11,219 and coal represented 10.65 percent of total Logan County employment. ${ }^{43}$ In 2002, Logan produced 11,676,279 tons of coal with 5,527,369 (or 47.3 percent) of the coal mined using MTR. ${ }^{44}$ The 2000 census registered the population of Logan County at 37,710 , and recorded a median income of $\$ 24,603{ }^{45}$ The five largest employers in the county as of December 2003 were the Logan County Board of Education, Logan General Hospital, Wal-Mart Stores, Inc., Automated Payroll Systems, and Apogee Coal Company. The county has a five-year unemployment rate of 8.6 percent, $^{46}$ and in 1999, 24.1 percent of County residents lived in poverty. ${ }^{47}$

${ }^{42}$ Center for Economic Research, Logan County, WV, County Data (Morgantown, WV: West Virginia University, July 1991).

${ }^{43}$ West Virginia Bureau of Employment Programs, Employment and Unemployment Data (Charleston, WV: Bureau of Employment Programs, Research, Information and Analysis, 2004), available from: http://www.state.wv.us/bep/lmi/ew2003/ew03x045.htm, http://www.state.wv.us/bep/lmi/ew2002/ew02x045.htm, July 11, 2004.

${ }^{44}$ Coal Facts 2003, 10.

${ }^{45}$ U.S. Bureau of the Census, Population, 2000.

${ }^{46}$ West Virginia Bureau of Employment Programs, Employment and Unemployment Data (Charleston, WV: Bureau of Employment Programs, Research, Information and Analysis, 2004), available from: http://www.state.wv.us/bep/lmi/LATEEMP.HTM, July 11, 2004. Statistics gathered by adding and dividing from the various appropriate searches per each county.

${ }^{47}$ U.S. Bureau of the Census, West Virginia Quick Facts available from: http://quickfacts.census.gov/qfd/states/54/54045.html. July 11, 2004. 
Figure 1.4

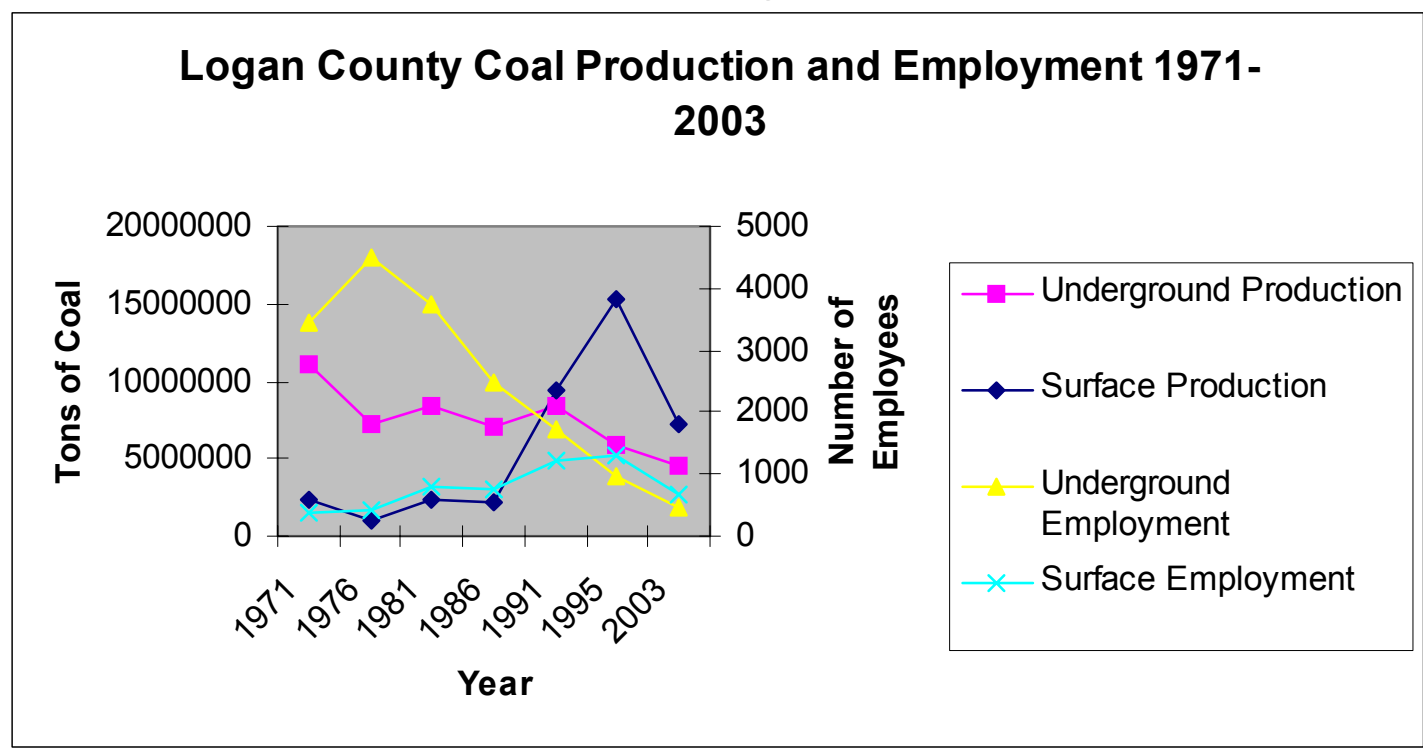

Source: Statistics from WV Coal Facts 1971-2003 and West Virginia Bureau of Employment Programs, 2003. Graph prepared by author.

\section{McDowell}

Map 1.5

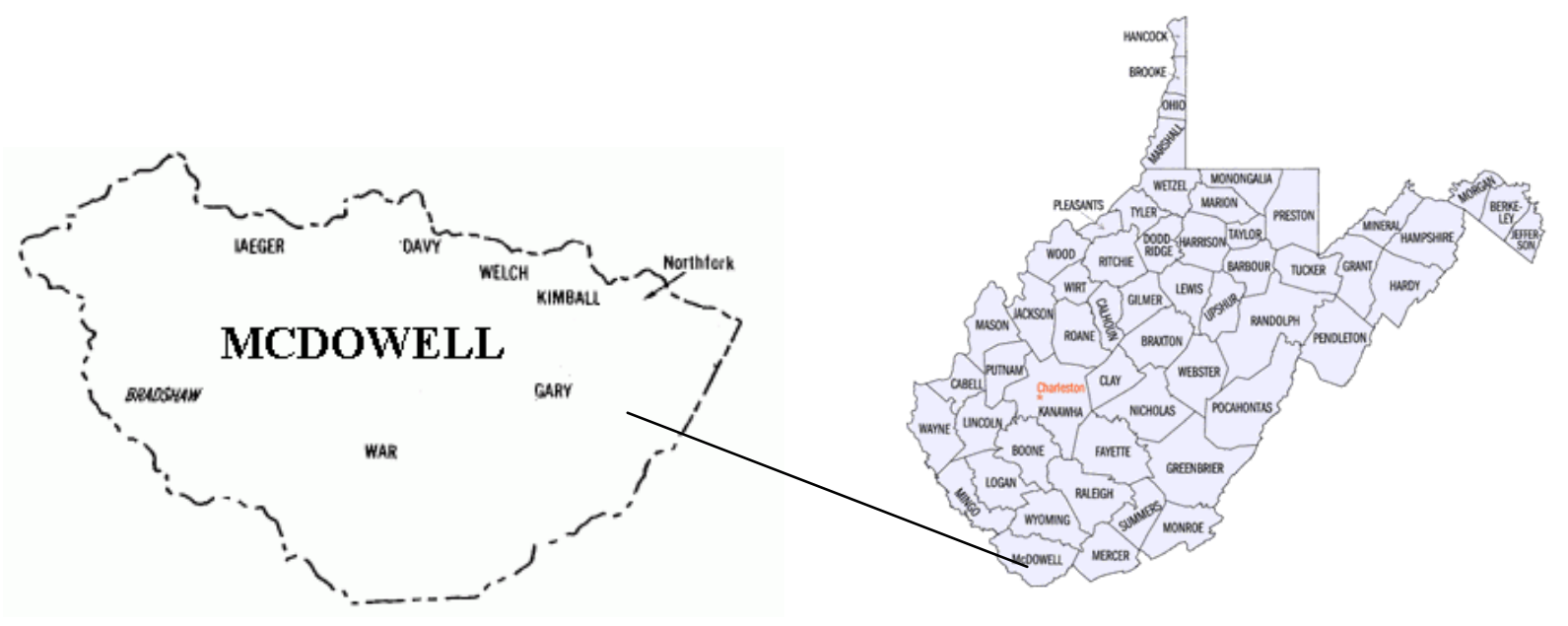


McDowell County, West Virginia, [Map 1.5] was formed in 1858 from Tazewell county (Virginia), and is 533 square miles. ${ }^{48}$ Prior to its becoming a county, McDowell was part of one of the largest land grants of the Revolutionary War period which included parts of western New York, Pennsylvania, South Carolina, and Virginia, including large tracts in what is now West Virginia. Given as a bequest to Robert Morris, then considered "the wealthiest man in America," for his loyalty, the territory was far too large for one person to manage and soon succumbed to "squatter's rights." Not having any clear rights to the land would prove problematic and the land soon reverted back to state ownership. One of the richest coal seams in the country was accidentally found by McDowell County blacksmith Jordan Nelson in the 1860s, but the ruggedness of the area made the excavation of the coal impractical until the railroad came through in $1887 .^{49}$ The same year, coal was first mined in the county, and by 1893 , it was home to twenty mines and 966 coke ovens. ${ }^{50}$

In 1970, 7,266 residents of McDowell County made their living through coal mining. ${ }^{51}$ The County enjoyed steady coal employment until the early 1980s when mining employment began to plummet. ${ }^{52}$ By 2003 , the county had only 738 coal mining jobs, a decrease of 103 coal mining and related jobs from 2002 when 841 such jobs existed in the County. [Please see Figure 1.5 for an illustration of employment and production trends for McDowell County.] Total employment for the county in 2003 was 4,896 jobs. Coal represented 15 percent of total

\footnotetext{
${ }^{48}$ Thomas Hatcher, Geneva Steele, Sandra Long, and Christine Carr McGuire, eds., The Heritage of McDowell County, West Virginia, 1858-1995 (War, WV: McDowell County Historical Society, 1995), 7.

${ }^{49}$ Ibid., 3-4, 19-24.

50 Jean Battlo, McDowell County in West Virginia and American History (Parsons, WV: McClain Printing Company, 1998), 122.

${ }^{51}$ Center for Economic Research, McDowell County, WV, County Data (Morgantown, WV: West Virginia University, July 1991).

${ }_{52}$ West Virginia Bureau of Employment Programs, Employment and Unemployment Data (Charleston, WV: Bureau of Employment Programs, Research, Information and Analysis, 2004), on the internet at http://www.state.wv.us/scripts/bep/lmi/cntydata.cfm, see 1980-89, 1990-1999 information for McDowell.
} 
McDowell County employment. ${ }^{53}$ In 2002, the County delivered 4,514,677 tons of coal to the market with 101,755 (or 2 percent) obtained by utilizing MTR. ${ }^{54}$ The 2000 Census registered the population of McDowell County at 27,329 and noted a median income of only $\$ 16,931$, the lowest median income of the nine counties. ${ }^{55}$ The five largest employers in the county as of December 2003 were McDowell County Board of Education, Council of Southern Mountains, West Virginia, Welch Emergency Hospital, McDowell County Commission, and McDowell County Continuous Care. The county has a five-year unemployment rate of 11.06 percent, ${ }^{56}$ and in $1999,37.7$ percent of its residents lived in poverty. ${ }^{57}$ McDowell also has the highest unemployment and poverty rates of the nine county subregion.

${ }^{53}$ West Virginia Bureau of Employment Programs, Employment and Unemployment Data (Charleston, WV: Bureau of Employment Programs, Research, Information and Analysis, 2004), available from: http://www.state.wv.us/bep/lmi/ew2003/ew03x047.htm http:/www.state.wv.us/bep/lmi/ew2002/ew02x047.htm, July 12, 2004.

${ }^{54}$ Coal Facts 2003, 10.

${ }^{55}$ U.S. Bureau of the Census, Population, 2000.

${ }^{56}$ West Virginia Bureau of Employment Programs, Employment and Unemployment Data (Charleston, WV: Bureau of Employment Programs, Research, Information and Analysis, 2004), available from: http://www.state.wv.us/bep/lmi/LATEEMP.HTM, July 11, 2004. Statistics gathered by adding and dividing from the various appropriate searches per each county.

${ }^{57}$ U.S. Bureau of the Census, West Virginia Quick Facts available from: http://quickfacts.census.gov/qfd/states/54/54047.html. July 11, 2004. 


\section{Figure 1.5}

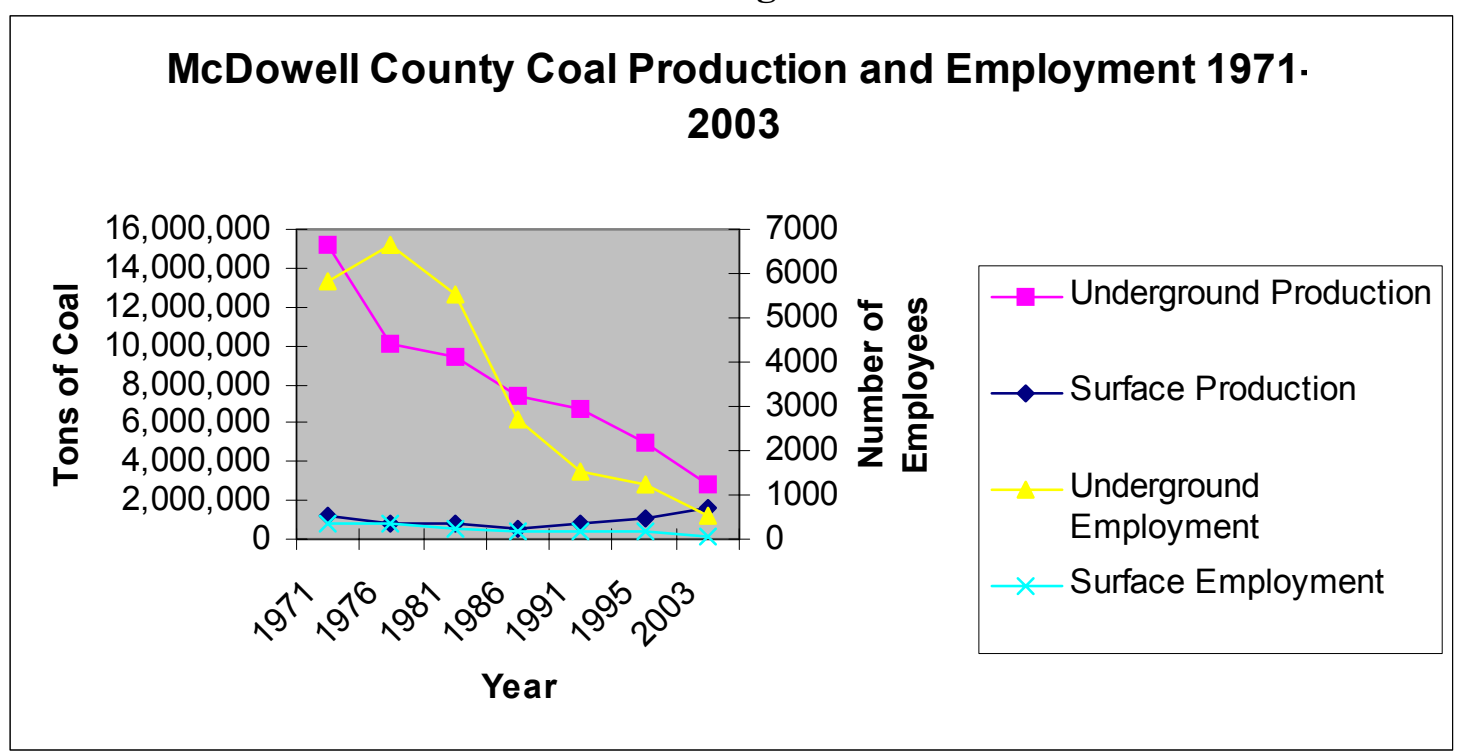

Source: Statistics from WV Coal Facts 1971-2003 and West Virginia Bureau of Employment Programs, 2003. Graph prepared by author.

\section{Mingo}

Map 1.6

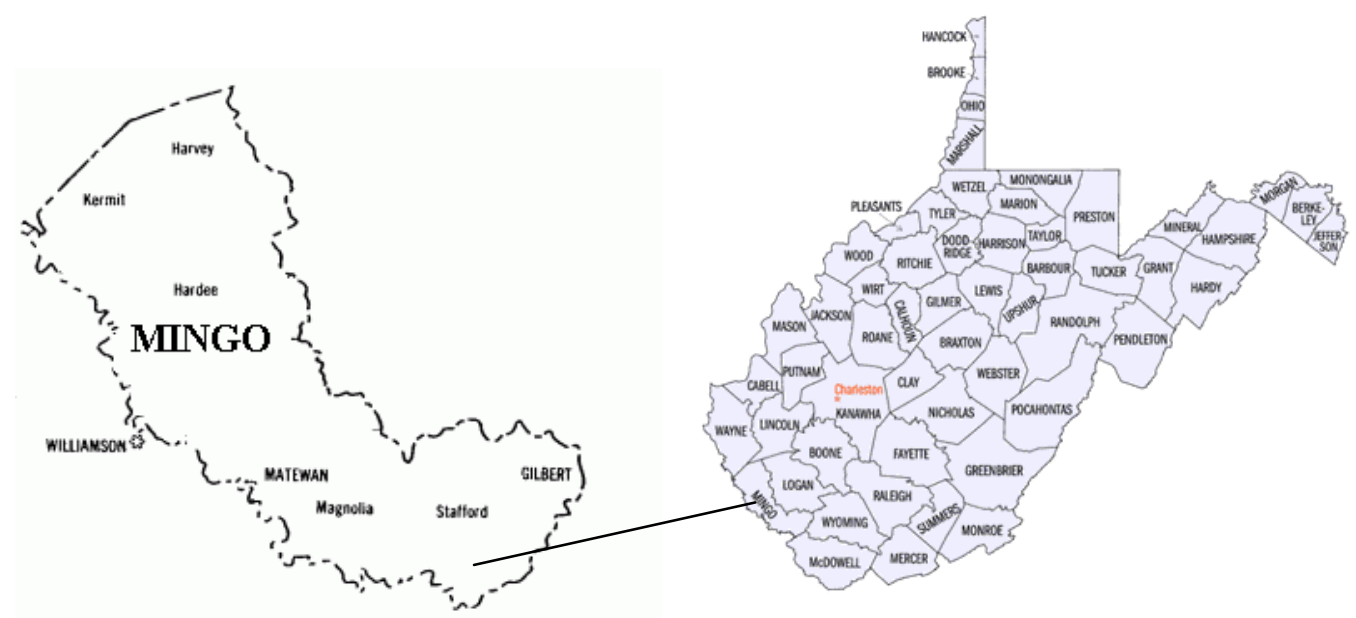

Mingo County, West Virginia, [Map 1.6] was formed on January 23, 1895, the last of

West Virginia's 55 counties to be created. It was formed from a part of Logan County and comprises 454 square miles. $^{58}$ Coal was first mined in the county around $1891 .{ }^{59}$

${ }^{58}$ Rebecca J. Bailey, "Matewan Before the Massacre: Politics, Coal, and the Roots of Conflict in Mingo County, 1793-1920 (Ph.D. diss., West Virginia University, 2001), 82.

${ }^{59}$ Ibid., 37. 
In 1970, 1,124 residents of Mingo County were employed as miners. ${ }^{60}$ In 2003, total employment for the county was 7,338. Coal represented 21.6 percent of employment in the county as the County saw a decrease of 292 mining jobs from 2002 to $2003(1,880$ to 1,588 jobs) ${ }^{61}$ [Please see Figure 1.6 for an illustration of employment and production trends for Mingo County.] In 2002, 19,995,196 tons of coal were mined in Mingo County with 5,879,504 tons of that coal (or 29.4 percent) mined through MTR. ${ }^{62}$ The 2000 Census registered the population of Mingo County at 28,253 and listed a median income of $\$ 21,347 .{ }^{63}$ The five largest employers in the county as of December 2003 were Mingo County Board of Education, Mountaineer Coal Development Company, Williamson Memorial Hospital, Mingo Logan Coal Company, and Appalachian Precision Hardwood Floor. The county has a five-year unemployment rate of 10.58 percent. ${ }^{64}$ In 1999, 29.7 percent of County residents lived in poverty. ${ }^{65}$

${ }^{60}$ Center for Economic Research, Mingo County, WV, County Data (Morgantown, WV: West Virginia University, July 1991).

${ }^{61}$ West Virginia Bureau of Employment Programs, Employment and Unemployment Data (Charleston, WV: Bureau of Employment Programs, Research, Information and Analysis, 2004), available from: http://www.state.wv.us/bep/lmi/ew2003/ew03x059.htm, http://www.state.wv.us/bep/lmi/ew2002/ew02x059.htm, July 12, 2004.

${ }^{62}$ Coal Facts 2003, 10.

${ }^{63}$ U.S. Bureau of the Census, Population, 2000.

${ }^{64}$ West Virginia Bureau of Employment Programs, Employment and Unemployment Data (Charleston, WV: Bureau of Employment Programs, Research, Information and Analysis, 2004), available from: http://www.state.wv.us/bep/lmi/LATEEMP.HTM, July 11, 2004. Statistics gathered by adding and dividing from the various appropriate searches per each county.

${ }^{65}$ U.S. Bureau of the Census, West Virginia Quick Facts available from: http://quickfacts.census.gov/qfd/states/54/54059.html, July 12, 2004. 
Figure 1.6

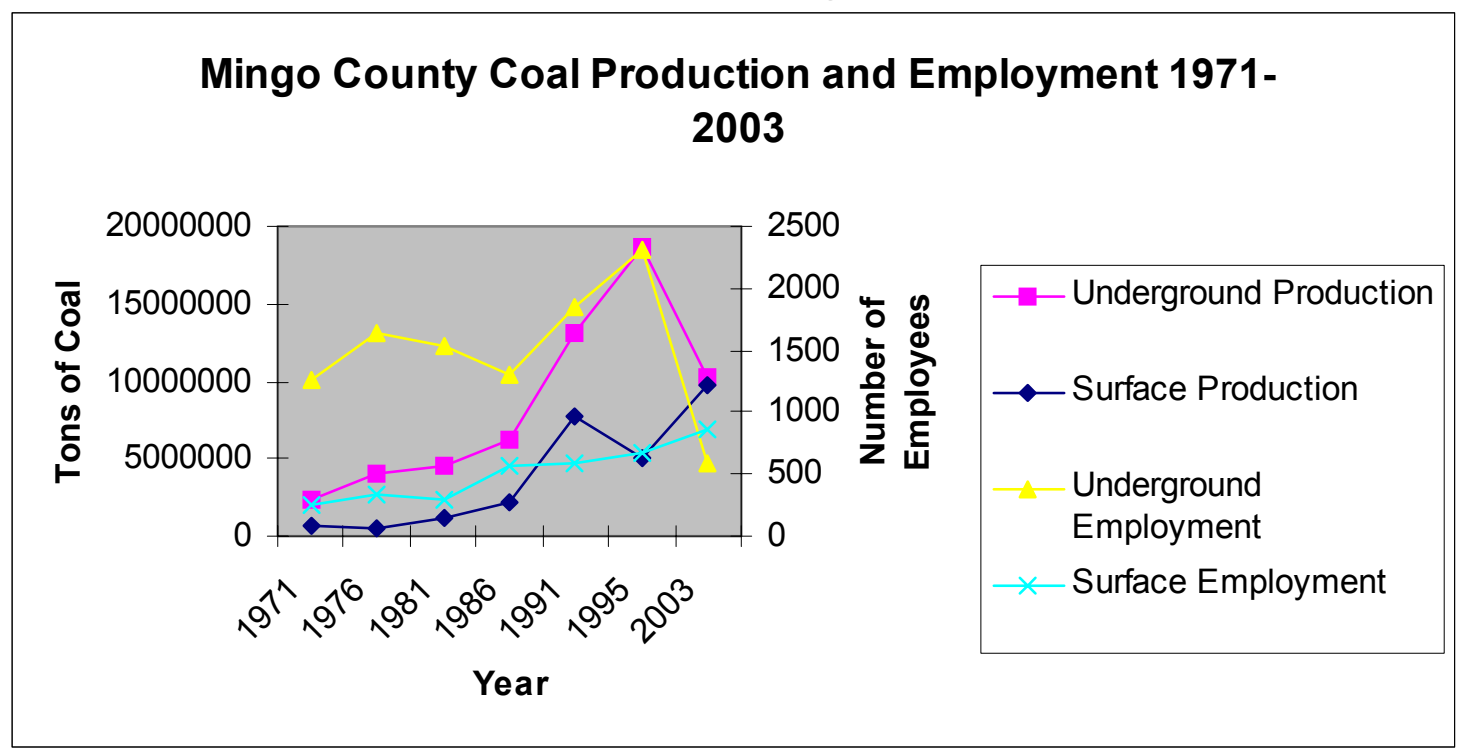

Source: Statistics from WV Coal Facts 1971-2003 and West Virginia Bureau of Employment Programs, 2003. Graph prepared by author.

\section{Nicholas}

Map 1.7

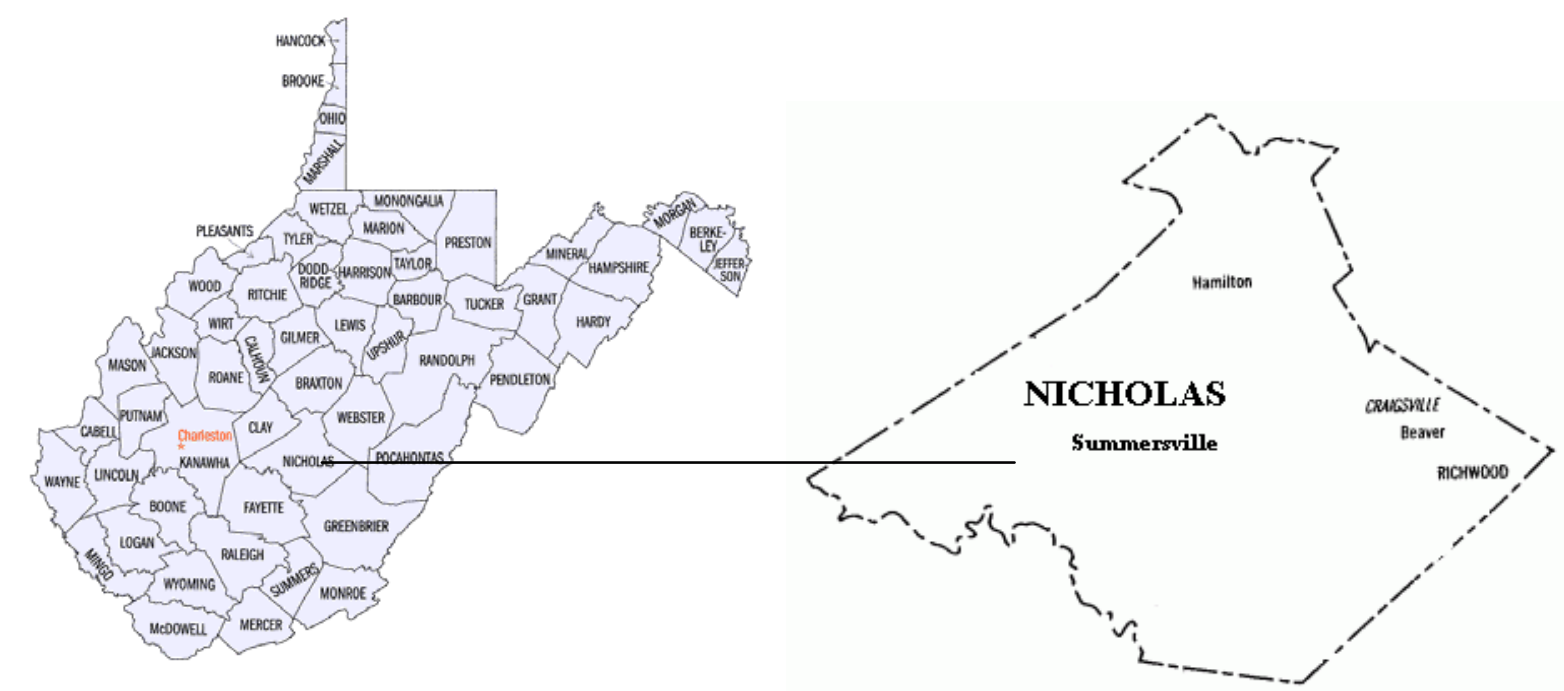

Nicholas County, West Virginia, [Map 1.7] was formed in 1818 from parts of Greenbrier,

Kanawha and Randolph Counties (Virginia), and encompasses 649 square miles. ${ }^{66}$ Leases to mine coal were first issued in $1909 .^{67}$ The County had rich agricultural possibilities, with a full

${ }^{66}$ William G. Brown, History of Nicholas County, West Virginia (Richwood, WV: The News Leader, 1954; reprint, Richwood, WV: The News Leader, 1981), 21.

${ }^{67}$ Ibid., 109. 
" $2 / 3$ of the soils in the county" being well suited for growing fruit such as apples, cherries, strawberries, and peaches. In 1954, the quality of the potatoes was as high as those grown in Idaho and the wilderness district of the county could produce 300 bushels an acre; however, the agricultural possibilities took a backseat to natural resource extraction and has remained there ever since. ${ }^{68}$

In 1970, 2,947 residents of Nicholas County were employed through coal mining. ${ }^{69}$ The county saw an increase in employment during the 1970s, and employment in the industry has vacillated between slight increases and decreases since then. ${ }^{70}$ Nicholas County saw a slight increase in mining jobs from 2002 to 2003 as an increase of 18 jobs from 613 in 2002 and 631 in 2003. ${ }^{71}$ [Please see Figure 1.7 for an illustration of employment and production trends for Nicholas County.] Still, in 2002, that miniscule amount of employees managed to extract $5,121,073$ tons of coal with 4,297,260 (or fully 83.9 percent) of that production coming from MTR sites. $^{72}$ Total employment for the county in 2003 was 8,235 with coal mining and related jobs representing 7.6 of that amount. ${ }^{73}$ The 2000 census registered the population of the County at 26,562 and recorded a median income of $\$ 26,974 .{ }^{74}$ The five largest employers in the county as of December 2003 were Nicholas County Board of Education, Summersville Memorial

\footnotetext{
${ }^{68}$ Ibid., 402, 405-406.

${ }^{69}$ Center for Economic Research, Nicholas County, WV, County Data (Morgantown, WV: West Virginia University, July 1991).

${ }^{70}$ West Virginia Bureau of Employment Programs, Employment and Unemployment Data (Charleston, WV: Bureau of Employment Programs, Research, Information and Analysis, 2004), available from: http://www.state.wv.us/bep/lmi/LATEEMP.HTM, July 12, 2004. Select Nicholas, then 1980-89, 1990-1999 information see 1980-89, 1990-1999 information.

${ }^{71}$ West Virginia Bureau of Employment Programs, Employment and Unemployment Data (Charleston, WV: Bureau of Employment Programs, Research, Information and Analysis, 2004), available from: http://www.state.wv.us/bep/lmi/ew2002/ew02x067.htm, http://www.state.wv.us/bep/lmi/ew2003/ew03x067.htm, July 12, 2004.

${ }^{72}$ Coal Facts 2003, 10.

${ }^{73}$ West Virginia Bureau of Employment Programs, Employment and Unemployment Data (Charleston, WV: Bureau of Employment Programs, Research, Information and Analysis, 2004), available from: http://www.state.wv.us/bep/lmi/ew2003/ew03x067.htm, July 12, 2004.

${ }^{74}$ U.S. Bureau of the Census, Population, 2000.
} 
Hospital, Wal-Mart Stores, Inc., Columbia West Virginia, Inc., and Coastal Coal WV, LLC. The county has a five-year unemployment rate of 7.96 percent $^{75}$ and in 1999, 19.2 percent of County residents lived in poverty. ${ }^{76}$

\section{Figure 1.7}

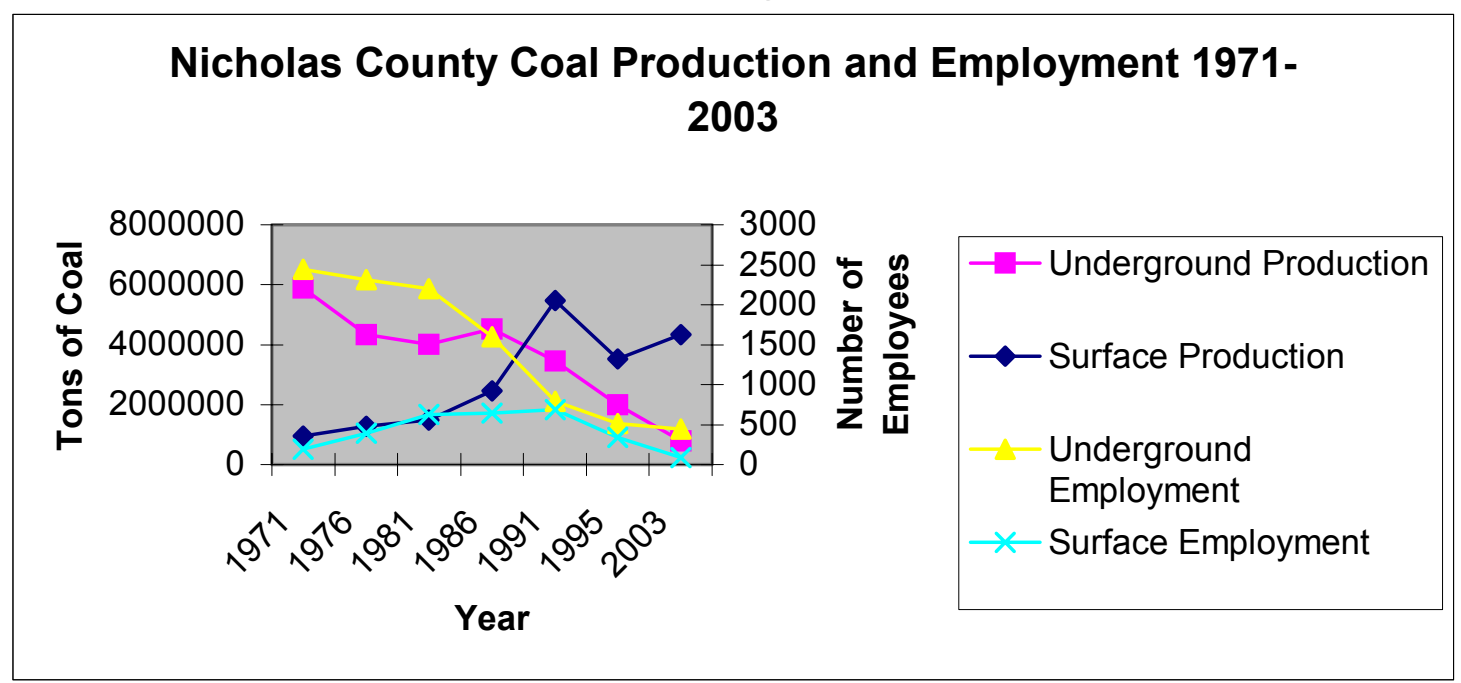

Source: Statistics from WV Coal Facts 1971-2003 and West Virginia Bureau of Employment Programs, 2003. Graph prepared by author.

\section{Raleigh}

Map 1.8

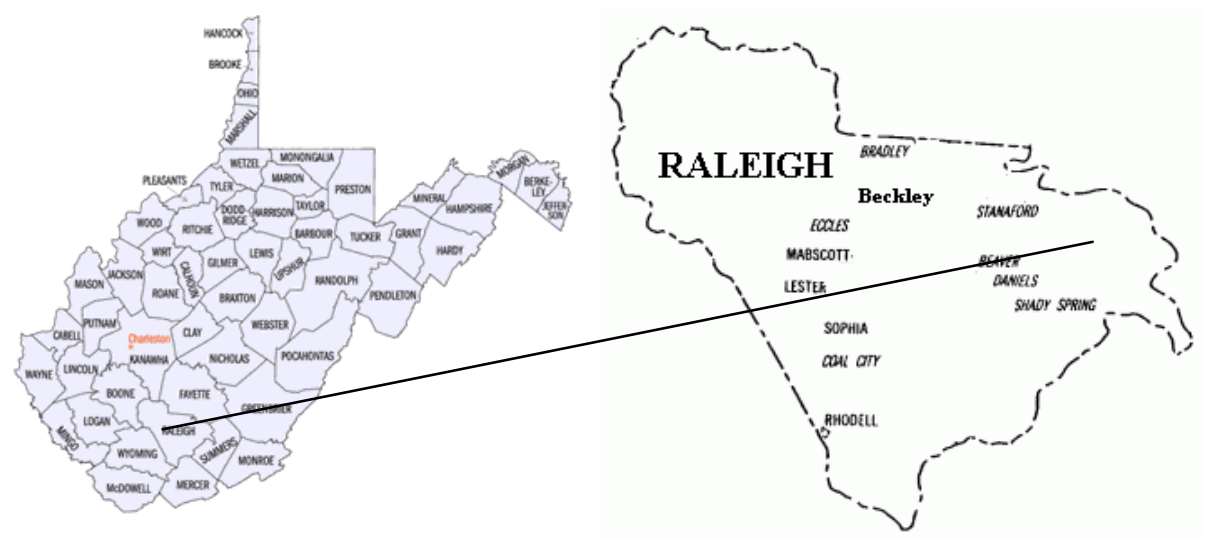

${ }^{75}$ West Virginia Bureau of Employment Programs, Employment and Unemployment Data (Charleston, WV: Bureau of Employment Programs, Research, Information and Analysis, 2004), available from: http://www.state.wv.us/bep/lmi/LATEEMP.HTM, July 11, 2004. Statistics gathered by adding and dividing from the various appropriate searches per each county.

${ }^{76}$ U.S. Bureau of the Census, West Virginia Quick Facts available from: http:/quickfacts.census.gov/qfd/states/54/54067.html, July 12, 2004. 
Raleigh County, West Virginia, [Map 1.8] was formed in 1850 from Fayette County and encompasses 607 square miles. ${ }^{77}$ Coal was first mined in the county in 1891, but no significant amount was mined until 1894 when the county produced 54,169 tons. Coal mine openings and production numbers increased along with the advancement of the Virginian and C\&O railways. By 1910 , the county had operations throughout its boundaries. ${ }^{78}$

In 1970, 3,875 residents of Raleigh County made their living through coal mining. The county saw a steady rise in employment through 1980. After that time, a decrease began. ${ }^{79}$ The area lost 208 mining and mining related jobs from 2002 to 2003 as employment fell from 1,392 jobs in 2002 to 1,184 jobs in 2003. [Please see Figure 1.8 for an illustration of employment and production trends for Raleigh County.] Total employment for the county in 2003 was 29,965, mining represented only 3.9 percent of Raleigh County direct employment. ${ }^{80}$ In 2002, Raleigh County mines produced 8,868,391 tons of coal with 377,968 (or 4 percent) mined through MTR. ${ }^{81}$ The 2000 Census registered the population of the county at 79,220 and recorded a median income of $\$ 28,181 .^{82}$ The five largest employers in the county as of December 2003 were Raleigh County Board of Education, Raleigh General Hospital, Appalachian Regional Healthcare, Wal-Mart Stores, Inc., Veterans Administration Medical Center. The county has a five-year unemployment rate of 5.72 percent which is lower than the other nine county subregion $14-15$.

${ }^{77}$ Virgil Lewis, History of West Virginia. In Two Parts (Philadelphia: Hubbard Brothers Publishers, 1889),

${ }^{78}$ Jim Woods, Raleigh County, West Virginia (Beckley, WV: BJW Printing \& Office Supplies, 1994), 323.

${ }^{79}$ West Virginia Bureau of Employment Programs, Employment and Unemployment Data (Charleston, WV: Bureau of Employment Programs, Research, Information and Analysis, 2004) available from: http://www.state.wv.us/bep/lmi/LATEEMP.HTM, July 12, 2004. Select Raleigh, then 1980-89, 1990-1999 information, see 1980-89, 1990-1999 information.

${ }^{80}$ West Virginia Bureau of Employment Programs, Employment and Unemployment Data (Charleston, WV: Bureau of Employment Programs, Research, Information and Analysis, 2004), available from: http://www.state.wv.us/bep/lmi/ew2003/ew03x081.htm, http://www.state.wv.us/bep/lmi/ew2002/ew02x081.htm, July 12, 2004.

${ }^{81}$ Coal Facts 2003, p. 10.

${ }^{82}$ U.S. Bureau of the Census, Population, 2000. 
except Kanawha County. ${ }^{83}$ In 1999, 18.5 percent of County residents lived in poverty. ${ }^{84}$ Again, only Kanawha County had better numbers in this category than Raleigh. Raleigh has recently begun to diversify its economic base including the promotion of tourism, establishment of a University, and a high-profile private high school. There is also much commercial development in the Beckley area of Raleigh County to take advantage of the two interstates and one heavily trafficked route that intersect in the area. In addition, the King Coal Highway, once completed, is sure to bring even more traffic into the area.

Figure 1.8

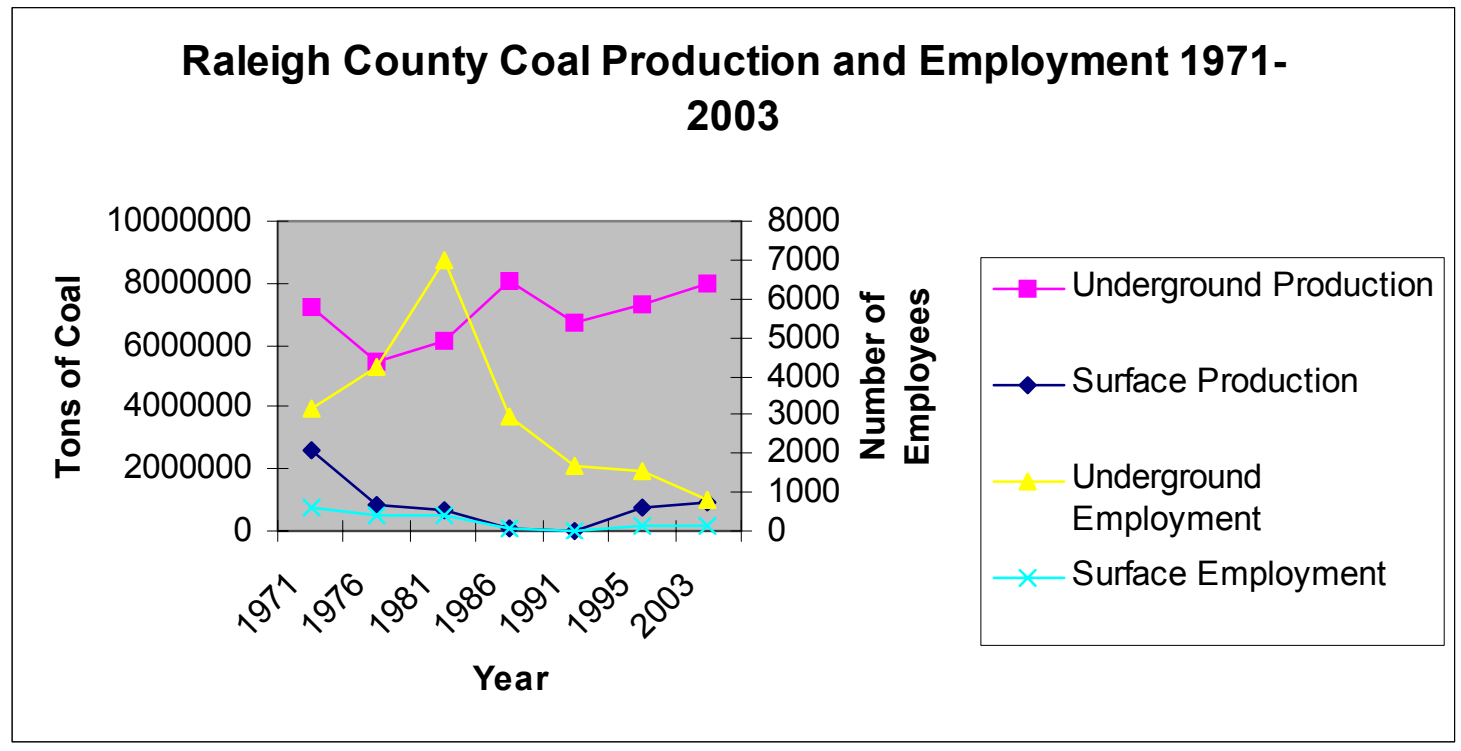

Source: Statistics from WV Coal Facts 1971-2003 and West Virginia Bureau of Employment Programs, 2003. Graph prepared by author.

${ }^{83}$ West Virginia Bureau of Employment Programs, Employment and Unemployment Data (Charleston, WV: Bureau of Employment Programs, Research, Information and Analysis, 2004), available from: http://www.state.wv.us/bep/lmi/LATEEMP.HTM, July 11, 2004. Statistics gathered by adding and dividing from the various appropriate searches per each county.

${ }^{84}$ U.S. Bureau of the Census, West Virginia Quick Facts available from: http:/quickfacts.census.gov/qfd/states/54/54081.html, July 12, 2004. 


\section{Wyoming}

Map 1.9

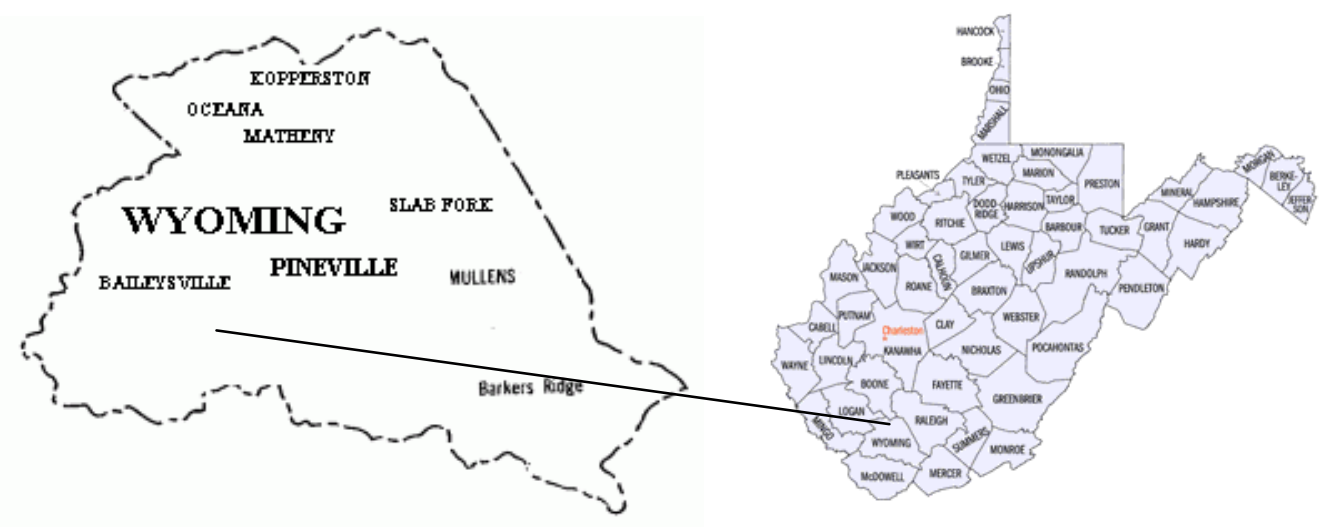

Wyoming County, West Virginia, [Map 1.9] was formed on January 26, 1850, from the upper portion of Logan county (Virginia) and presently encompasses some 507 square miles. ${ }^{85}$ At its founding, the county contained mostly farmers. In fact, the 1850 census shows a county where virtually every occupant farmed for a living. ${ }^{86}$ Most people in the county lived (and still live) in the narrow valleys in between "deep V-shaped gorges." Fertile bottomland has always been scarce in the area. ${ }^{87}$ While coal extraction began in the county in 1907 , it was not until 1910 with the opening of the Virginian Railway that the economic and logistical feasibility of coal extraction would dovetail. ${ }^{88}$

In 1970, the coal industry employed 4,502 people in Wyoming County. ${ }^{89}$ As of 2003, there were 938 coal mining employees in Wyoming County (down from 1093 in 2002). [Please see Figure 1.9 for an illustration of employment and production trends for Wyoming County.] Total employment for the county in 2003 was 5,331. Coal mining and mining related

\footnotetext{
1965), 10-11

${ }^{86}$ Ibid., 54-81.

${ }^{87}$ Samuel R. Cook, Monacans and Miners: Native American and Coal Mining Communities in Appalachia (Lincoln, NE: University of Nebraska Press, 2000), 136.

${ }^{88}$ Bowman, 13

${ }^{89}$ Center for Economic Research, Wyoming County, WV, County Data (Morgantown, WV: West Virginia University, July 1991).
}

${ }^{85}$ Mary Keller Bowman, Reference Book of Wyoming County History (Parsons, WV: McClain Print Co., 
employment accounted for 17.5 percent of total direct employment in the county. ${ }^{90}$ In 2002 , Wyoming County mines produced 8,196,399 tons of coal with 1,952,114 (or 23.8 percent) of the coal being mined through MTR. ${ }^{91}$ Presently, 25,708 people reside in Wyoming County and the median income is $\$ 23,932$. The five largest employers in the county in 2003 were the Wyoming County Board of Education, U.S. Steel Mining Company, LLC, the Wyoming County Council on Aging, Inc., Wyoming County Opportunity Council, Inc., and S.E.T. Personnel Services Unlimited. While many mines operate in the area, as in many of the other counties, these mines are largely subsidiaries of larger companies and so their numbers are not reflected as providing highest employment. The county's five year unemployment average was 7.98 percent, ${ }^{92}$ and in 1999, 25.1 percent of Wyoming County residents lived below the federal poverty level. ${ }^{93}$

${ }^{90}$ West Virginia Bureau of Employment Programs, Employment and Unemployment Data (Charleston, WV: Bureau of Employment Programs, Research, Information and Analysis, 2004), available from: http://www.state.wv.us/bep/lmi/ew2003/ew03x109.htm, http://www.state.wv.us/bep/lmi/ew2002/ew02x109.htm, July 11, 2004.

${ }_{92}^{91}$ Coal Facts 2003, 10.

${ }^{92}$ West Virginia Bureau of Employment Programs, Employment and Unemployment Data (Charleston, WV: Bureau of Employment Programs, Research, Information and Analysis, 2004), available from: http://www.state.wv.us/bep/lmi/LATEEMP.HTM, July 11, 2004. Statistics gathered by adding and dividing from the various appropriate searches per each county.

${ }^{93}$ U.S. Bureau of the Census, West Virginia Quick Facts available from: http://quickfacts.census.gov/qfd/states/54/54109.html, July 11, 2004. 
Figure 1.9

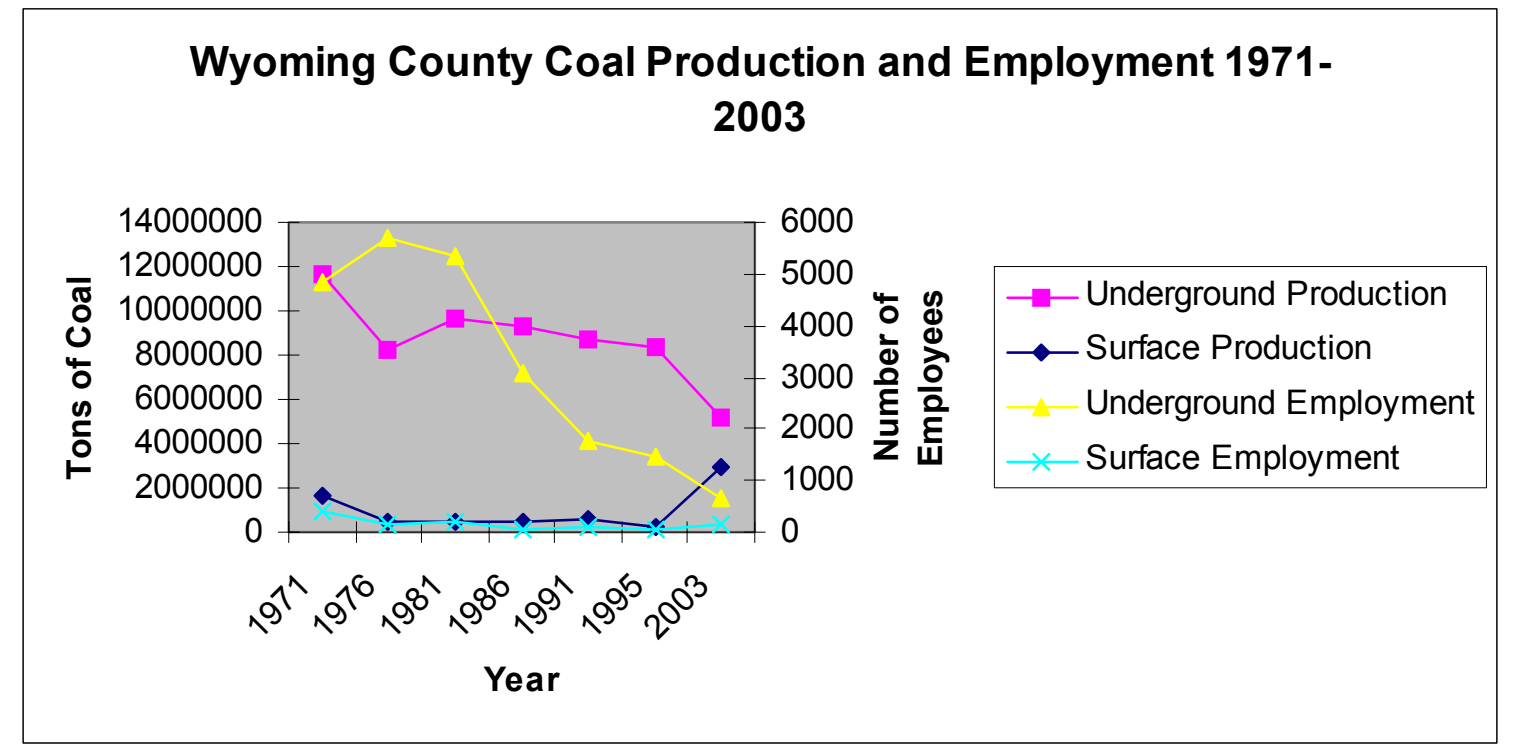

Source: Statistics from WV Coal Facts 1971-2003 and West Virginia Bureau of Employment Programs, 2003. Graph prepared by author.

\section{Strip Mining in West Virginia: The Mountains Laid Bare}

Although underground mining dominated the coal industry in West Virginia through most of the twentieth century, strip mining also had its place. Northern West Virginia operators were the first to introduce strip mining to the state in 1916. World War I brought with it a high demand for coal to fuel the war effort both at home and abroad as coal shortages occurred across the country. Miners were encouraged to mine coal as a patriotic duty. During this time of patriotic furor, strip mining became a more acceptable way to obtain coal. ${ }^{94}$ This heightened demand along with the negligible start-up capital required for these operations made surface mining more attractive to investors. These mines employed a fraction of the miners of underground operations, and as new operations, the strip mines were not burdened with previous contractual obligations and placed highest priority on the new markets created by the war. At a

${ }^{94}$ Corbin, Life, Work, and Rebellion, 176-178. 
time of nearly unlimited demand, coal meant high dollars to be made. ${ }^{95}$ The heightened need for coal during the War resulted in the strip mining industry becoming more respectable and gaining easy entry into the mainstream coal industry. Still, massive strip mining in the region did not occur until World War II by which time equipment for stripping had improved, and more roads had been surfaced allowing for easier access to the coal operations. With easier access to the coal seams and a renewed need for the product, strip mines once again burgeoned in the region. From 1938-1942, strip-mine coal companies operating in the state increased from only two to forty-one. ${ }^{96}$ Strip mining supplied the demand for coal faster, with fewer casualties, and higher productivity per man than underground mining. In fact, during World War II, strip mining was considered a significant contributor to the war effort. ${ }^{97}$ Many of the new mining contractors had been engaged in highway construction, and while they were unfamiliar with mining they had the equipment and the manpower trained to obtain the coal. In his essay, Robert F. Munn noted that “[p]roduction increased ten-fold between 1939 and 1943." He identified 1947 as "the peak year" and reported that ten per cent of all West Virginia coal was obtained through strip mining. While largely contained within the northern part of the state for twenty-five years, strip mining made its way to the southern part of the state entering Raleigh and Fayette Counties first and was entrenched by $1943 .^{98}$

Strip mining held its own during the 1950s and began to expand again during the 1960s. From 1962 forward, the importance of strip mining to the coal industry increased until it became an integral part to West Virginia's natural resource dependent economy. It was not until massive scale stripping began on a regular basis during the 1970s that it drew much attention by West

\footnotetext{
${ }^{95}$ Robert Munn, “The First Fifty Years of Strip Mining in West Virginia, 1916-1965," West Virginia History 35 (October 1973): 66-74.

96 Ibid., 68, 71 .

${ }^{97}$ Ibid., 68.

${ }^{98}$ Ibid., 69.
} 
Virginians. Equipment became larger and massive strip mining jobs became much easier and cost effective for the companies. ${ }^{99}$ As the state witnessed a decrease in coal mining employment, the tonnage had steadily increased. In 1970, 45,261 West Virginia jobs were supplied due to coal mining and 143,132,284 tons of coal were produced. Thirty-two years later, in 2002, 15,377 people were employed by the coal companies and together they produced $163,896,890$ tons of coal. ${ }^{100}$ Mechanization has continually made coal jobs obsolete; however, with MTR, the overall numbers have dwindled at an even faster pace as fewer and fewer people are needed to operate the large strip mining machinery. As Figure 1.10 illustrates, surface mining production held steady in the nine counties during the 1970s, but saw a significant growth beginning in the 1990s. Since 1990, a definite trend can be seen with surface mining employment consistently decreasing even as production increases. As noted above, larger coal companies are responsible for a vast majority of MTR coal extraction as the machinery necessary to mine using MTR is extremely expensive. On the other hand, MTR operations require far less manpower than traditional underground and even traditional surface mining.

${ }^{99}$ Ibid., 71.

${ }^{100}$ Coal Facts 2003, 14. 
Figure 1.10

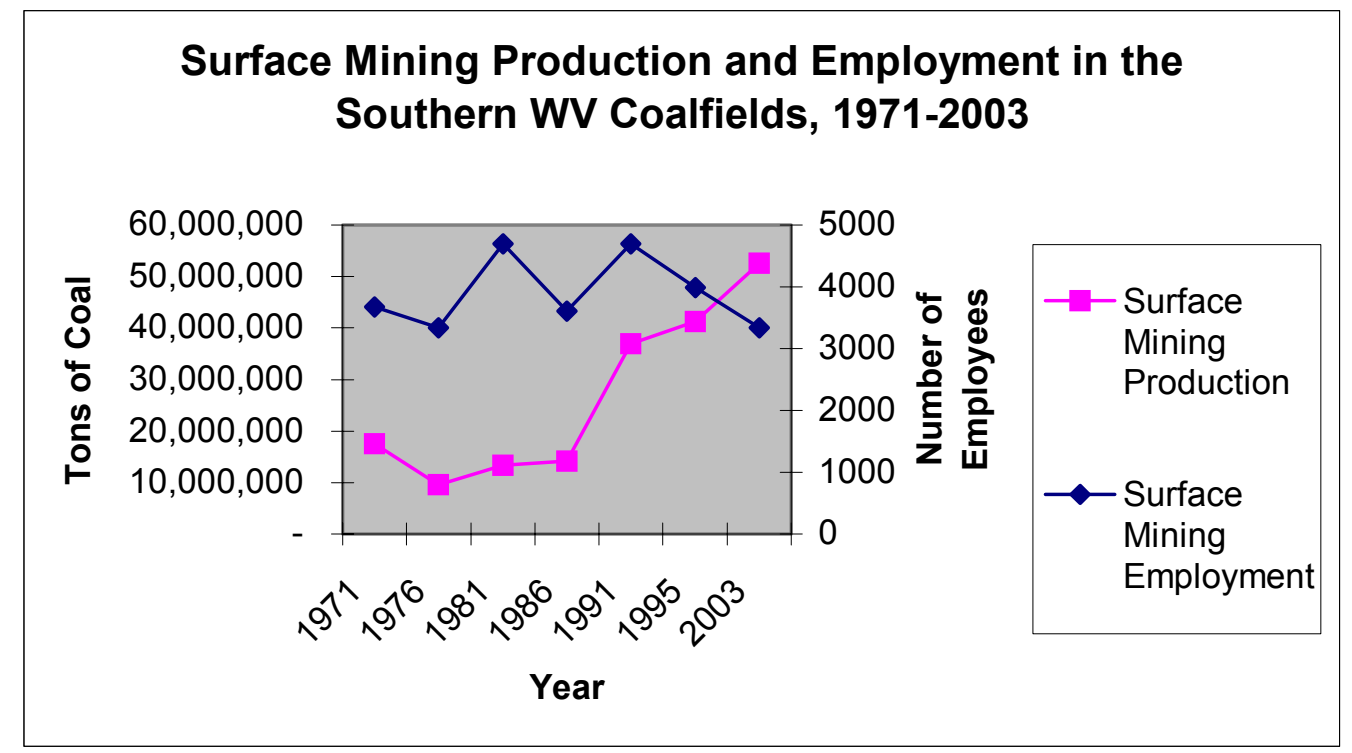

Source: Statistics from WV Coal Facts 1971-2003 and West Virginia Bureau of Employment Programs, 2003. Graph prepared by author.

Surface mining brought with it new ways for the residents of coal communities to lose power. The men who worked surface mines were heavy equipment operators, and they were largely non-union. Not until the operations became so large that the resulting scars could be witnessed on the landscape did any major protest against the practice take place. A whole new type of hopelessness emerged in the coalfields. Because the idea that their region was only good for natural resource extraction was well ingrained, the people's loyalty was often pulled between the desire to preserve the land on the one hand and the need for good paying jobs on the other. Surface mines destroyed people's lives on a whole different level, and left them virtually helpless to stop it. Mountaintop removal mines polluted streams and filled in valleys. Some of these valley fills are among the largest man-made earthen structures in the world. ${ }^{101}$ While residents found themselves despondent with the consequences of MTR, many felt that they had little to no

${ }^{101}$ Shiva Prasad B. Kolli, “Analyses of Coal Extraction and Spoil Handling Techniques in Mountainous Areas” (MA thesis, West Virginia University, 2001), 34. 
choice but to accept things the way they were in order to preserve the dwindling coal mining jobs.

While strip mining did not flourish in the state until the latter half of the twentieth century, in 1939 West Virginia became the first state to pass a strip mine control act. There was little fanfare and little enforcement of the sparse law, and strip mining continued to grow in the region. $^{102}$ Significantly, the framers of the 1939 measure realized the risks involved for the bill cited the need for the legislation "because strip mining 'causes soil erosion, increases the hazards of floods, causes the pollution of streams of water...and creates dangerous hazards in life and property."'103 The act was amended in 1945 to legislate more extensive post-mining use, but again the lack of enforcement made the amendments nearly a moot point. Further amendments were passed in 1963, but they only weakened an already anemic law. The amount of money required as a bond was reduced, and the requirement that operators declare what area a permit would cover was removed. ${ }^{104}$ These revisions left the people with even less legal redress than before. The strip miners essentially were given carte blanche to mine in any manner without regard for the public welfare, and if that meant ruining the land of a private citizen to secure the coal then so be it. Mineral rights were given far higher priority in the law than surface rights.

In the spirit of President Lyndon Johnson's Great Society community action programs, antipoverty workers helped form a citizen's movement against strip mining in the southern coalfield counties, including Boone, Fayette, Raleigh, and Wyoming in $1967 .{ }^{105}$ While the movement idled soon after, it was revived in 1970 by then gubernatorial candidate Jay

\footnotetext{
102 Munn, "The First Fifty Years," 72-73.

${ }^{103}$ Chad Montrie, "To Save the Land and People: A History of Opposition to Coal Surface Mining in Appalachia" (Ph.D. diss., Ohio State University, 2001), 191; Chad Montrie. To Save the Land and People: A History of Opposition to Surface Coal Mining in Appalachia (Chapel Hill, NC: The University of North Carolina Press, 2003), 110-111. Montrie's book, and the dissertation that it grew out of are excellent in detailing the struggles of Appalachian citizens to monitor and fight against the strip mining industry.

${ }^{104}$ Montrie, "To Save the Land and People," 193-194; Montrie, To Save the Land and People, 111.

105 Montrie, "To Save the Land and People," 195.
} 
Rockefeller who used his own money to start Citizens to Abolish Strip Mining (CASM).

Rockefeller abandoned the strip mining cause in 1972 after losing a gubernatorial bid to Arch

Moore. In 1971, the West Virginia legislature considered a bill banning strip mining completely

in the state. Supporters of the bill quickly pointed out that the jobs versus the land argument did not apply as the majority of strip mine workers were not local, but from out-of-state. Proponents also noted that these workers were also not miners, they were heavy equipment operators with transferable skills, and that surface mines actually took away jobs from underground miners. ${ }^{106}$ The legislature did not pass that bill, only a two-year moratorium that applied to only one-half of the fifty-five counties. There was never enough legislative support for an overall abolition as many of the legislators counted the coal industry among their major contributors. ${ }^{107}$

In the 1970s, the concern with Appalachia's environmental degradation stretched even into the religious sphere. In 1970, the Commission on Religion in Appalachia (CORA) compiled a "Dialogue Focuser" on strip mining in Appalachia. Realizing its economic, social, and political importance, the document hoped to create a forum for both sides to express their views on strip mining. At the time of the report, the debate over whether to allow strip mining at any level was intensifying. The companies' viewpoint focused on the need for coal for an energystrapped nation and postulated that the surface mined coal reserves could not be obtained by traditional, underground mining. Opponents of strip mining argued that the energy needs of the nation could be met with the abundance of coal available from traditional, underground methods. ${ }^{108}$ The document covered areas ranging from environmental effects to legal and

\footnotetext{
${ }^{106}$ Ibid., 194; Montrie, To Save the Land and the People, 108.

${ }^{107}$ Montrie, "To Save the Land and People," 187-189; Montrie, To Save the Land and People, 122-123.

${ }^{108}$ Commission on Religion in Appalachia, Strip Mining in Appalachia: A Social, Economic and Political Issue (Knoxville, TN: Commission on Religion in Appalachia, 1970).
} 
political ramifications, and illustrates the seriousness of the strip mining debate just as mountaintop removal was beginning in Fayette County, West Virginia.

Nationally, federal legislators were getting involved in the strip mining debate in the 1970s because states failed to enforce even the weakest state laws, and court judgments favoring strip mine operators made federal intervention necessary. West Virginia congressional representative, Ken Hechler, introduced a bill to ban surface mining in February 1971 at the same time as anti-stripping forces in West Virginia carried the battle into the state legislature. The federal and state efforts were doomed to failure. Two more attempts would see congressional passage of regulations only to meet with presidential vetoes in 1974 and $1975 .{ }^{109}$ It was only with the passage of the 1977 Surface Mining Control and Reclamation Act (SMCRA) that federal regulations were finally approved for strip mining. While a far weaker bill than its two predecessors, the act did provide for some control and entrusted regulation to the states. The act prohibited the dumping of debris on steep slopes, and provided an abandoned mine reclamation program funded by a coal tax and established the Office of Surface Mining (OSM) in the Department of the Interior. ${ }^{110}$ SMCRA also allowed for concerned citizens to call for inspections of surface mines, and gave them the right to participate in those inspections and to file lawsuits against those regulators who failed to enforce the law. ${ }^{111}$ Among the noted allowances in the act was permitting mountaintop removal surface coal mining (MTR). Finally, the people had their protective legislation, but still no power of enforcement or redress. Now,

${ }^{109}$ Montrie, "To Save the Land and People," 282, 288-289; Montrie, To Save the Land and People, 138, 163-173.

${ }^{110}$ Montrie, "To Save the Land and People," 303, 306; Montrie, To Save the Land and People, 178.

${ }^{111}$ Montrie, "To Save the Land and People," 305; Mark Squillace, Strip Mining Handbook: A Coalfield Citizens' Guide to Using the Law to Fight Back Against the Ravages of Strip Mining and Underground Mining (Washington, D.C.: Environmental Policy Institute and Friends of the Earth, 1990), 89. 
residents were dependent on the erstwhile regulators to enforce even more rules, and still had not achieved the outright ban of strip mining that many had sought.

It is almost certain that neither legislators or those who supported the ban on surface mining, could have imagined the huge twenty-story machines that were on the horizon. The beginning of mountaintop removal in West Virginia occurred in 1970 when Cannelton Industries, Inc., began mining Bullpush Mountain near the Fayette-Kanawha County line. ${ }^{112}$ However, it was not until the introduction of the twenty-story machinery in the 1980s that MTR enjoyed a vast expansion in the state. The massive machines on mountaintop removal sites have ensured that more coal can be obtained with less human labor and greatly increased productivity. The expansion of mountaintop removal in West Virginia since its inception in the 1970s has grown at an accelerated pace from forty-four permits covering 9,800 acres throughout the 1980s to the granting of permits covering 12,540 acres in a nine-month period in 2002 alone. ${ }^{113}$

As strip mining increased throughout the 1980s, particularly mountaintop removal mining, and as demand for coal decreased during the decade, coal mining and related employment plummeted. Corporations needed to produce coal with the cheapest bottom line possible. With the large machinery used in MTR doing the work of hundreds of men, MTR did just that. As the method became increasingly more prolific throughout the 1990s, a new era of protests against this more extreme version of strip mining occurred. Citizen groups sprung up throughout the coalfields in an attempt to mobilize residents against the perceived oncoming environmental and employment disaster. One of the first of these groups was the Ohio Valley Environmental Coalition (OVEC) formed in 1987. Located in Huntington, West Virginia, it was

\footnotetext{
${ }^{112}$ Ken Ward, Jr., "Flattened: Most Mountaintop Mines Left as Pasture Land in State, Charleston (West Virginia) Gazette, August 9, 1998.

${ }^{113}$ Ken Ward, Jr., "Corps Says it Doesn't Regulate Valley Fills: Stance Could Help Suit Over Mountaintop Removal," Charleston Gazette, July 19, 1998; Ken Ward, Jr., "Strip-Mined Acreage Up Again in W.Va.," Charleston Gazette, November 4, 2003.
} 
originally formed as a citizen's group opposing the construction of a chemical hazardous waste incinerator near Ironton, Ohio. By the end of the 1990s, halting MTR had become the group's top priority. The West Virginia Highlands Conservancy (WVHC) was yet another state environmental group that embraced the cause of educating the public to the dangers of MTR and working towards the halting of the mining technique. One of the most recent additions to these groups is the Coal River Mountain Watch (CRMW) that was formed by a group of concerned citizens in Boone County, West Virginia. Located in the heart of MTR country, CRMW acts as an important voice against the practice directly affecting their homes and environment. Their work is particularly notable and crucial as they are located in the county with the highest MTR coal production.

\section{Conclusion}

Since coal mining began in southern West Virginia, underground mining has been the dominant form of extraction, but strip mining has steadily increased its market share. As equipment changed and surface mining became more prolific, the environmental and aesthetic problems associated with surface mining gained the attention of citizens throughout the coalfields. Huge draglines introduced in the 1980s led to the expansion and proliferation of MTR in the 1990s. The nine southernmost coalfield counties overwhelmingly depend on coal mining to fuel their economies. This lack of diversification has proven devastating as continual mechanization has resulted in fewer mining jobs and in environmental destruction. The increase in MTR led to the organization of various citizen groups and existing groups' incorporating MTR into their lists of environmental scourges. Among those groups were the Coal River Mountain Watch (CRMW), the Ohio Valley Environmental Coalition (OVEC) and the West Virginia Highlands Conservancy (WVHC). These groups continue to become more vocal as 
MTR operations expand throughout the southern coalfields and as the United Mine Workers of America (UMWA), once a stalwart voice for coalfield communities, continues to support MTR operations where some members have employment. 


\section{Chapter Two:}

Solidarity Forever?:

The United Mine Workers of America and Southern West Virginia Coal Communities

"I stood for the union and walked in the line.

I fought against the company.

I stood for the U. M. W. of A.

Now, who's gonna stand for me?"1

From Coal Tattoo by Billy Edd Wheeler, singer/songwriter

The United Mine Workers of America was organized in 1890 in Columbus, Ohio, in an effort to unite coal miners towards a "unity of action and purpose, in demanding and securing by lawful means the just fruits of [their] toil." 2 Throughout its tenure, the union strove to secure better working conditions and decent pay for its members. Its efforts can be seen through many important pieces of legislation - the eight-hour workday, collective bargaining rights, previously unheard of health and retirement benefits, and the enactment of better federal coal mine health and safety standards. For many members it acted as a surrogate, or extended family, and for decades provided an avenue by which the miners could improve their economic advantages in a hostile world. The union also acted as a mediator between the workers and the coal companies, and presented a united voice for thousands of miners. ${ }^{3}$

Coal fueled the nineteenth century industrial revolution and the United States coal industry burgeoned to meet the high demand. Southern West Virginia with its abundant coal reserves witnessed first hand the changes brought by the industrial revolution at varying speeds. Because of its rugged landscape, the southern coalfields were a special challenge to coal operators. Only when railroads were constructed in the backcounties could coal and other

\footnotetext{
${ }^{1}$ Billy Edd Wheeler, Coal Tattoo, Ode to the Little Brown Shack Out Back, Kapp Records KL-1425, 1963.

${ }^{2}$ Maier B. Fox, United We Stand: the United Mine Workers of America, 1890-1990 (Washington, DC: United Mine Workers of America, 1990), 22.

${ }^{3}$ Ibid., iii-iv.
} 
natural resources be brought to the national marketplace. ${ }^{4}$ From the late 1890 s until 1933, the union was thwarted at nearly every avenue. Companies fiercely fought efforts to unionize West Virginia's southern coalfields through brute force coercion and paternalism. The companies formed alliances amongst themselves to resist unionization efforts, hiring outside agencies (such as Pinkerton agents and Baldwin-Felts detectives) to enforce their anti-union mandates. While a few operators resisted the use of such brute force, the majority of operators stayed firm in their use. $^{5}$

Coal mining remained a difficult vocation complete with physical challenges, hazards to the miners' health, poor pay, and low social status. Therefore, the union represented some hope to the miners of improving not only their pay, but their dignity, allowing them a voice they had not before enjoyed. In order to obtain this, the miners were willing to make great sacrifices. The union struggled to make headway into the southern West Virginia coalfields. Throughout the early twentieth century most of their attempts were thwarted. While the union made some inroads, it did not firmly entrench itself in this area until 1933 after the federal government gave workers the right to unionize. The southern coalfield counties were the most difficult to organize and the companies would stop at nothing to keep their coalfields union free. Southern West Virginia witnessed numerous "battles" between miners trying to unionize and the hired company thugs with the lone goal of stopping these efforts. Following are brief accounts of four such battles.

\footnotetext{
${ }^{4}$ Phil Conley, History of the West Virginia Coal Industry (Charleston, WV: Education Foundation, Inc., 1960), 43-71; Corbin, Life, Work, and Rebellion, 2; Eller, Miners, Millhands, and Mountaineers, 65-75; Ronald Lewis, Transforming the Appalachian Countryside: Railroads, Deforestation, and Social Change in West Virginia, 1880-1920 (Chapel Hill, NC: University of North Carolina Press, 1998 ), 7.

${ }^{5}$ Corbin, Life, Work, and Rebellion, 106-145; Keith Dix, What's a Coal Miner to Do? The Mechanization of Coal Mining (Pittsburgh, PA: University of Pittsburgh Press, 1988), 168-173; Eller, Miners, Millhands, and Mountaineers, 209-210; Maier, United We Stand, 146-147; Crandall Shifflett, Coal Towns: Life, Work, and Culture in Company Towns of Southern Appalachia, 1880-1960 (Knoxville, TN: University of Tennessee Press, 1991), 5560; John Alexander Williams, West Virginia and the Captains of Industry (Morgantown, WV: West Virginia University Library, 1976), 190-191, 250-251.
} 
A little known, but interesting "mine battle" occurred in Raleigh County in 1903. It was in this year that organizers and supporters of the United Mine Workers of America engaged in a gun battle with U.S. Marshals in what locals call the Battle of Stanaford. There exists no consistent telling of the battle, but varying accounts do exist and this telling aligns consistencies and incorporates them all. In 1902, some 259 miners walked out from Raleigh County's fledgling coal industry in an attempt to bring the union into their county. In late February 1903, a U.S. Marshal met with threats when he tried to deliver a court injunction against the walkout to 33 miners who had marched from Fayette County to what is now East Beckley. The Marshal then formed a posse of some fifty "special marshals," and was joined by the Raleigh County sheriff and a Baldwin-Felts detective working with the C\&O Railroad. A UMWA official had tried to contact the strikers to tell them to give up quietly, but reported that as the phone and telegraph lines were owned by coal operators, the messages were refused delivery. Mother Jones who visited the area afterwards recounted seeing the remains of miners who had been killed while sleeping. The posse approached Stanaford City in the early morning and attacked the striking miners. At the end of the battle, three men were dead and eight more would soon succumb to their wounds for a total of eleven deaths at the "Battle of Stanaford." Among the dead were three black miners. Some miners were incarcerated for their part while still others fled. By the summer of 1903, the UMWA had withdrawn from the New River coalfield. Successful organization of the county would not occur until 1933 when President Franklin Roosevelt promised to send armed forces into West Virginia if the workers were stopped from their newly acquired right to unionize. ${ }^{6}$

\footnotetext{
${ }^{6}$ Jim Woods, Raleigh County, West Virginia (Beckley, WV: BJW Printing \& Office Supplies, 1994), $367-$ 376; Lois C. McLean, "Warm Receptions and Cordial Invitations for Mother Jones in West Virginia," in Goldenseal Book of the West Virginia Mine Wars: Articles reprinted from Goldenseal Magazine, 1977-1991 (Charleston, WV: Pictorial Histories Publishing Company, 1991), 3-9. The Battle of Stanaford seems to have been nearly forgotten by
} 
In April 1912, the small inroad the UMWA had made in the Kanawha Field was jeopardized when the coal operators in the Paint Creek area refused to renew their contract. The miners had hoped to secure more equitable wages for other area miners. The miners walked out on strike. Soon, Baldwin-Felts guards forcibly removed striking miners from their company homes. In response, the miners erected tent colonies and took up arms. They petitioned to Governor William E. Glasscock to intervene on their behalf, but he responded that he could not tell men (in this case, Baldwin Felts guards) where they could go. In July, after the death of two men, the sheriff asked Governor Glasscock to intervene by sending the National Guard in. Although Glasscock complied, he chastised the sheriff for failing to do his duty by arresting the perpetrators. Within four months, the strike had reached to nearby Cabin Creek. A rally in the state capital of Charleston brought out 6,000 miners and supporters, featuring Mary Harris Jones, better known as Mother Jones, as speaker. As the sheriff refused to arrest offenders, the Governor soon felt that he had no recourse but to declare martial law to give the National Guard permission to do just that. Miners who had committed criminal acts were tried before a military court. ${ }^{7}$ Mine guards were forced from the strike area and one month later, with order restored, Glasscock lifted martial law. Coal operators quickly organized to bring in strikebreakers, a move that was met with violence from the strikers. While not permitting Baldwin-Felts agents to

scholars of West Virginia's Mine Wars. Occasionally, it is given a passing, cursory mention in a sentence about union-miner struggles, or invoked in "remember Stanaford" quotes, but not much detail is ever provided on just what we should remember. Aside from Woods, the second best telling of what happened at Stanaford is encompassed within a few paragraphs in Lois McLean's Goldenseal article on Mother Jones. Mother Jones' autobiography provides a cursory mention of the encounter. Yet, as many people lost their lives as a result of Stanaford as did during the far better known "Matewan Massacre." Considering the breadth of scholarship concerning the mine wars and struggle for unionization, lack of scholarship concerning this early battle is puzzling. The struggle in Stanaford was a great defeat for the union. Using a myriad of primary newspaper sources, Jim Wood, editor for the Beckley Register-Herald for thirty-five years, began to rectify that oversite with the most thorough recounting of the events at Stanaford this author has read. His retelling of the events in the one thorough history of Raleigh County described how this battle effectively drove the UMWA out of the county as afterwards mine owners doubled their efforts to keep the mines union-free. This union-free stance helped cement the power relationship in the New River coalfield heavily in favor of the coal companies.

${ }^{7}$ Richard D. Lunt, Law and Order vs the Miners: WV 1906-1933 (Charleston, WV: Appalachian Editions, 1992), 23-33. 
return, Glasscock allowed "watchmen" approved by the National Guard to come in. Violence continued throughout and culminated in a violent episode in February 1913. A train known as the Bull Moose Special made its way into the tent colony under the blanket of night and fired upon the sleeping residents, killing one. The miners attacked mine guards in Mucklow in retaliation leaving sixteen more dead on both sides. In total, Glasscock ordered three separate periods of martial law. In the end, Glasscock was unsuccessful in mediating the strike and his successor, Henry D. Hatfield, was left to pick up the pieces. Hatfield did not repeat the mistake of his predecessor by lifting martial law, realizing it was necessary to maintain order and to force the coal companies to come to the table to work out an agreement. This move halted the coal companies from continuing their intimidation tactics as represented by the bullying BaldwinFelts agents and the hired watchmen. The agreement that Governor Hatfield was eventually able to hammer out an agreement that allowed workers "the explicit right to join the UMW without discrimination" as well as the right to hold meetings on "company property." 8 In the end, the miners were little better off than they had been before the strike. This strike is often described as the first West Virginia mine war.

During the 1920s, Mingo County was known as "bloody Mingo" because of all of the violence that rocked the area as the United Mine Workers of America tried to unionize the county. Thwarted at every attempt by company hired Baldwin-Felts Detective agents, the tension culminated on May 19, 1920. An exchange of gunfire between the detectives and Matewan's police chief had numerous repercussions in addition to the ten initial deaths. A subsequent twenty-eight month long strike led to two dozen deaths. The gunfight resulted in

\footnotetext{
${ }^{8}$ Ibid.; Corbin, Life, Work, and Rebellion, 87-105; Howard B. Lee, Bloodletting in Appalachia: The Story of West Virginia's Four Major Mine Wars and Other Thrilling Incidents of Its Coal Fields (Morgantown, WV: West Virginia University, 1969), 17-47; Ken Sullivan, ed., The Goldenseal Book of the West Virginia Mine Wars (Charleston, WV: Pictorial Histories Publishing, 1991), 17-32.
} 
“West Virginia's longest and most controversial murder trial to date, a United States Senate investigation, the retaliatory assassination of [Matewan Police] Chief [Sid] Hatfield, and the largest armed civilian insurrection since the Civil War," at Blair Mountain, Logan County. ${ }^{9}$ This uprising became known as the Battle of Blair Mountain and took the U.S. Army to cease, representing the first time since the Civil War that armed military had been used against Americans. Nearly 10,000 coal miners were determined to bring "democracy" to the workers of southern West Virginia's Mingo and Logan Counties. After fighting with the sheriff of Logan County and his "special deputies," armed United States forces were called out to halt the insurgence. The rebellion crushed, the union was unable to mount another offensive in the southern coalfields until $1933 .^{10}$

Some companies sought a softer way to thwart unionization attempts by creating "model company towns." These endeavors embraced the idea of welfare capitalism, or paternalism. Born from the nineteenth century industrial revolution, welfare capitalism hoped to secure worker loyalty by offering benefits such as health care, death benefits, housing, annual and sick leave, and recreational facilities. The movement was at the height of its popularity at the turn of the twentieth century. Model towns worked in much the same way as traditional company towns with some striking exceptions. Model towns had numerous amenities that could not be found in traditional company towns, such as sturdy houses with indoor plumbing and appliances. The

\footnotetext{
${ }^{9}$ Rebecca J. Bailey, "Matewan Before the Massacre: Politics, Coal, and the Roots of Conflict in Mingo County, 1793-1920" (Ph.D. diss., West Virginia University, 2001), xiii. The retelling in this present work is particularly short since this event has been treated amply by others. For one excellent such account, see Bailey's thorough recounting of this and other Mingo County history that led up to the Matewan Massacre; for a detailed account of the Blair Mountain battle, please see Robert Shogan, The Battle of Blair Mountain: the Story of America's Largest Labor Uprising (Boulder, CO: Westview Press, 2004). Also of interest, Michael Meador, “The Red Neck War of 1921: The Miner's March and the Battle of Blair Mountain," in Goldenseal Book of the West Virginia Mine Wars: Articles reprinted from Goldenseal Magazine, 1977-1991 (Charleston, WV: Pictorial Histories Publishing Company, 1991), 57-63; Lunt, Law and Order, 121-144; for information on Matewan, in addition to Bailey's study, see the following, Corbin, Life, Work, and Rebellion in the Coal Fields, 195-252; Lee, Bloodletting in Appalachia, 51-58; Lunt, Law and Order, 91-120; Lon Savage, Thunder in the Mountains (Pittsburgh: Univ. of Pittsburgh Press, 1990); Sullivan, The Goldenseal Book of the West Virginia Mine Wars, part three.

${ }^{10}$ Meador, "The Red Neck War of 1921," 57-63.
} 
company often supplied the latest in entertainment, and some towns had a restaurant and a soda shop, movie theater, well stocked grocery and mercantile stores, expansive baseball field complete with the company's own team, and well kempt lawns, gardens, and sidewalks. Companies hired doctors to tend to their employees' needs and erected schoolhouses and sometimes even churches. ${ }^{11}$ The companies were selective of the tenants they allowed into the model company towns, and this often produced the desired results - a fierce loyalty of their workers to the company. The model company town infused coal camps with paternalism in an effort to halt unionization and foster loyalty to the company.

One of the last model company towns of the southern West Virginia coalfields was Kopperston, West Virginia, in Wyoming County. Wyoming County’s coal extraction began later than many of the surrounding counties, thus a later development of model company towns whose peak in the bituminous coalfields was between $1910-1920,{ }^{12}$ nearly two decades before Kopperston was formed. By the end of the 1930s, however, coal was being mined in Wyoming County full force. Some of the richest deposits rested in the Toney Fork area just outside of Oceana, West Virginia. By the end of the decade, some 10,000 acres of this largely wilderness and farm land had been purchased by Koppers Coal Company of Pittsburgh, Pennsylvania. ${ }^{13}$ As

\footnotetext{
${ }^{11}$ Robert Munn, "The Development of Model Towns in the Bituminous Coal Fields," West Virginia History 40 (Spring 1979), 243-253.

12 Ibid.

${ }^{13}$ Koppers Coal Company was part of the vast natural resource holdings of the Koppers Company. Eastern Gas and Fuel Associates bought into Koppers Coal holdings to become part of Koppers Coal and Transportation Company. In this capacity, they purchased majority holdings in the Virginian Railway, important in getting the coal out of the southern backcounties of West Virginia. This acquisition "completed the circle" of coal interests for the company. The organization now had a direct interest with every aspect of mining - the actual mining, transportation, and processing. In 1947, the Koppers company was ordered by the SEC to sell its extensive holdings in Eastern Gas and Fuel Associates. Koppers Coal division of Eastern Gas and Fuel was then renamed Beacon Coal. Eventually, Eastern Gas and Fuels coal holdings would be under a subsidiary, wholly owned by the company, named Eastern Associated Coal Company. In 1998, the now bankrupted Eastern Enterprise, the once seemingly union friendly company, sued the UMWA in an attempt to shirk its health care and retirement obligations where they had agreed to provide "cradle to grave" benefits for the company's employees. In a blow for unions and working people, the US Supreme Court ruled in the defunct company's (now part of Peabody Energy) favor citing that the company had not mined coal since 1966. However, the company's subsidiaries, including Eastern
} 
construction of homes began, the area was named for the coal company and became known as Kopperston. By 1943, more than 230 individual houses stood in the new mining community. ${ }^{14}$ The company told tenants that only the best could live in this coal camp. Everyone who lived in the coal camp, of course, worked for the mine, but not all of the miners who worked for Koppers lived in the coal camp. Some of the men who worked for Koppers had a long lineage in the valley and had families who had lived in the region for more than 100 years. These miners already owned their own land and homes, so they commuted back and forth. The many amenities were offered to all employees of Koppers Coal and their families, regardless of residence in the coal camp or not, and were readily available in the new town of Kopperston. With all the benefits that accompanied being employed by Koppers, just working for them became a privilege of sorts, much like living in their model town. The community boasted playgrounds for both children and adults, and included a farm baseball team that was nearly semi-professional; its own health service, complete with doctor, nurse, and ample medical supplies; a restaurant and soda fountain; mercantile; places of worship; and schools. Koppers even had a summer camp, Camp Lightfoot, for employee's children. Thomas Lightfoot, the director of the company's welfare and compensation division and for whom the camp was named, summed it up best,

"Many of the youngsters living in our mining towns some day will hold jobs with the company. The boys who attend the camp will, we hope, be our foremen, our

\footnotetext{
Associated Coal, had mined coal through the 1980s and signed contracts with the union in 1974, 1978 and 1981. Other companies attempts to shirk responsibilities and contracts did not meet with such favorable judicial attention. Please see, "Eastern Gas Joins in Koppers Merger: Mines, Coal Selling Agencies, Steamships and Dock to Go Under One Company," The New York Times, February 25, 1933; "Eastern Gas Gets Indirect Interest in Virginian Railway: Acquires Stock of Virginian Corp. Along with Associate, Koppers Co.," The New York Times, July 2, 1937; "Koppers Coal Becomes 'Beacon,"” The New York Times, October 3, 1947; "Court Rejects Companies' Appeal, Businesses Asked to be Relieved of Paying Benefits," Charleston Daily Mail, November 2, 1999.

${ }^{14}$ Paul Blankenship, From Cabins to Coal Mines: More History, Sketches, Anecdotes, Traditional Stories, Culture, and Families of Oceana and the Clear Fork Valley of Wyoming County, West Virginia (Beckley, WV: Central Printing, 2002), 223.
} 
superintendents and executives of the future, and we feel that their development is a matter of great importance for us." ${ }^{.15}$

Lightfoot's reasoning provided a perfect example of welfare capitalism in the model towns. The company, by promoting goodwill and loyalty to itself through benefits and amenities, could create an ideal capitalist man who believed that his continued personal success was permanently tied to the companies' best interests. In essence, doing the best for the company equaled doing the best for himself and his family. If a company was successful in creating this environment, it would surely be successful in creating a loyal workforce. At the time it was erected, it was recognized as an exemplary model company town. Thirty-five years later, praise was still being heaped on the coal camp. Two 1978 West Virginia Gazette articles examined the community and dubbed it "the classiest coal camp in Appalachia."

The union established itself in the area on November 4, 1938, with the charter of Local Union $7604,{ }^{16}$ and the Koppers Coal mine was organized soon afterward. Still, the paternalism spawned by Koppers' initial effort at welfare capitalism benefited Eastern Associated Coal Company, a subsidiary of Eastern Gas and Fuel who gained control of Koppers' coal holdings in the late 1940s. By all accounts, the workers and management had a good relationship. Eastern maintained Camp Lightfoot, the summer camp for miners' children, and many of the other amenities such as the company store and recreational playgrounds for decades. The company store, for instance, did not shut down until the 1980s. ${ }^{17}$ Employees typically spoke well of their treatment by Eastern. While the area mines did walk out during the wildcat strike of 1976, it was

\footnotetext{
15 "Miner's Children Play at Own Camp: 750 at a Time Spend Two Weeks in Hill Country of West Virginia," The New York Times, August 28, 1943.

${ }^{16}$ James David Kidd, president of UMWA Local Union 7604, telephone conversation with author, October 27, 2004. Kidd obtained the information from the LU's charter. Through most of the 1970s, LU 7604, with more than 1200 active members, was the largest local of District 17 which was the largest district of the UMWA. Today, there are only 4,000 union members in all of District 17 (now combined with District 29).

${ }^{17}$ The author clearly remembers obtaining her first bicycle at this company store and how the store clerk took her father's work information so the payments could be taken directly from her father's paycheck.
} 
commented that the workers were not walking out on Eastern, but against the Bituminous Coal Operators' Association. ${ }^{18}$ The houses, sold by Eastern to the residents in the 1950s, no longer belonged to the company and the town had also experienced changes, but clearly the welfare capitalism experiment had succeeded in Kopperston although perhaps not in the manner the company had initially hoped. ${ }^{19}$ The desire to hold off the union failed, but loyalty to the company remained.

While the company seemingly provided much for its model communities, miners still looked to the union to have a voice in their own fate. To this end, the union worked to secure an eight-hour work day and was instrumental in legislation that provided for the health and safety of miners. In a show of solidarity, union members banded together to ensure health and retirement benefits for their members and for the widows of union miners. Even with its history of protecting worker rights, the union witnessed a stark decline in its membership. During the 1940s and 1950s when coal employed hundreds of thousands of workers, most were union miners. By 2000, of the 71,000 miners throughout the United States, only 20,522 belonged to the union. ${ }^{20}$ [See Figure 2.1]

\footnotetext{
${ }^{18}$ Blankenship, From Cabins to Coal Mines, 234-236; Ann Hughey, "Kopperston...Coal Mining Town that's Different," Charleston Gazette, April 20, 1978.

${ }^{19}$ Blankenship, From Cabins to Coal Mines, 240; Ann Hughey, “Community Pride Evident in Classiest Coal Camp in Appalachia," Charleston Gazette, April 20, 1978.

${ }^{20}$ Catherine Lucey, "Coal Worker Membership Declines," Associated Press, August 2, 2002; Department of Energy, Energy Information Administration, "Average Number of Employees by State, Mine Type, and Union Type, 2000," Coal Industry Annual, 2000. Personal contact with the UMWA revealed that the union itself does not keep a record of membership numbers. Author was provided with overall mining employment numbers and suggestions of using percentages to get an estimate. Author instead continued searching. Special thanks to Ken Ward, Jr., Charleston Gazette and Melody Bragg, Miners Safety \& Health Administration for the UMW membership information they provided. Also see, David Peter, "Earnings, Health, Safety, and Welfare of Bituminous coal Miners Since the Encouragement of Mechanization by the United Mine Workers of America" (Ph.D. diss., West Virginia University, 1972); Joseph Shaplen, "Fullest War Help Pledged by Lewis," New York Times, October 7, 1942; Kenneth Noble, "Even in the Mines, There's an Urge to Merge," New York Times, October 12, 1986; Jonathan Hicks, "Labor Takes Heart in the Miner Walkout," New York Times, June 25, 1989; Dept. of Energy, Energy Information Administration, Coal Industry Annual Report Data Table, 1995, 2000 (Washington, DC: Department of Energy, 1995, 2000), available from http://tonto.eia.doe.gov/FTPROOT/coal/058495.pdf, http://www.eia.doe.gov/cneaf/coal/cia/html/tbl24p01p1.html.
} 
Figure 2.1

\begin{tabular}{|l|l|l|l|l|l|l|l|l|l|}
\hline \multicolumn{1}{|c|}{ Nationwide UMWA Membership 1941-2000 } \\
\hline 1941 & 1951 & 1955 & 1960 & 1965 & 1970 & 1985 & 1989 & 1995 & 2000 \\
\hline 300,000 & 349,406 & 185,499 & 139,038 & 94,229 & 92,565 & 85,000 & 65,000 & 37,226 & 20,522 \\
\hline
\end{tabular}

Source: see footnote 20

Membership had dwindled so much that by the early 1990s District 17 merged with

Beckley based District 29. By 2001, District 17 membership (which includes southern West Virginia as well as southwestern Virginia and eastern Kentucky) had declined from 30,000 members in 1979 to 4,000 members. ${ }^{21}$ By the beginning of the twenty-first century, Union miners produced "less than a fifth of American coal.",22

Much of this decline can be attributed to the dwindling number of miners overall. As the industry mechanized, employment declined. With the introduction of the continuous miner in the late 1940s (a move embraced by the union), employment inevitably plunged and has been steadily declining - with occasional increases - ever since. While earlier UMWA presidents had generally supported mechanization, under the leadership of John L. Lewis, the UMWA concluded that it must further embrace such mechanization to ensure the "long-run stabilization of the whole industry." ${ }^{23}$ Figure 2.2 shows the dwindling number of coal mining employees in West Virginia over a fifty-four year period. Many miners replaced by machines must have felt betrayed by union policy, but dictates of the marketplace forced the union to accommodate to mechanization as more and more small coal operators were pressed out of business by larger coal companies that could afford the new machinery. The decreases in mining employment, and hence union membership, left hundreds of thousands of people out of work. As the number of

\footnotetext{
${ }^{21}$ Edward Peeks, "New UMW Chief has Hard Job," Charleston Gazette, May 21, 2001.

${ }_{22}^{22}$ Barbara Freese, Coal: A Human History (Cambridge: MA: Perseus Books Group, 2003), 180.

${ }^{23}$ Dix, What's a Coal Miner to Do?, 161.
} 
unemployed miners increased, the number of West Virginia residents decreased accordingly, a trend that persisted from the 1950s down to the present day lows.

Figure 2.2

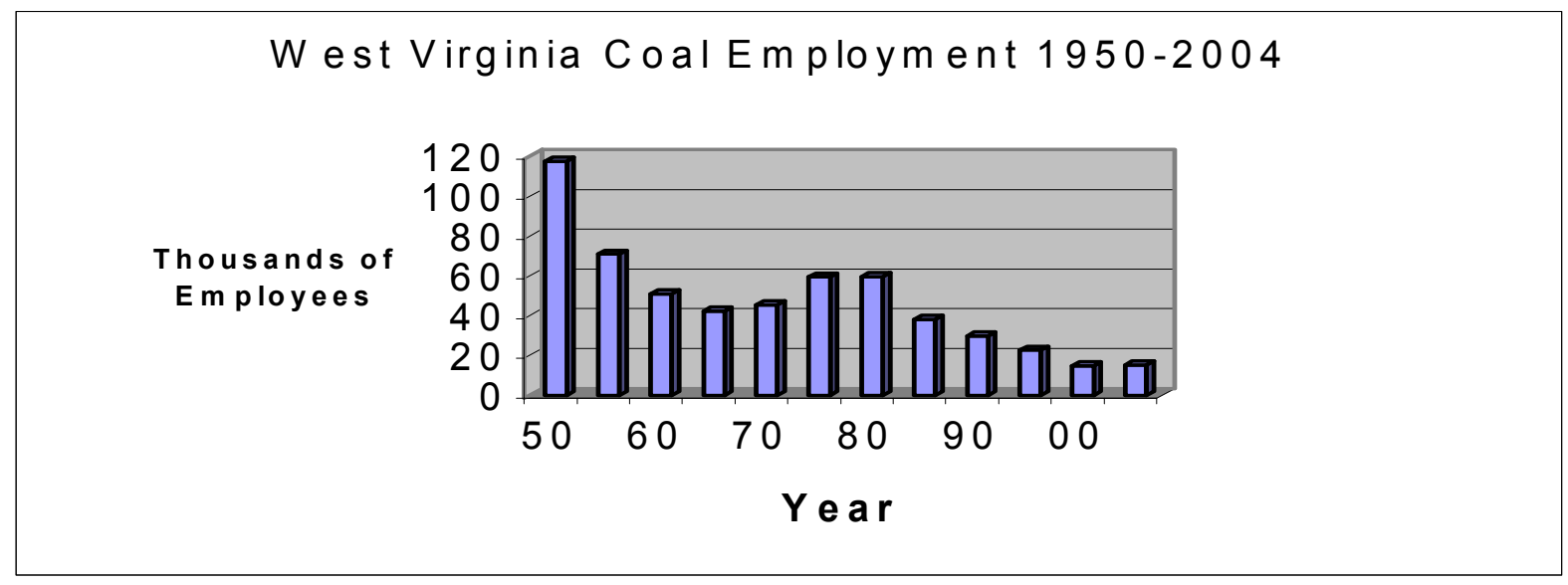

Source: Statistics from the West Virginia Bureau of Employment Programs. Graph prepared by author.

In addition to this mechanization, the union faced bitter opposition from the large multinational coal companies now doing business in the southern coalfields, such as A.T. Massey and by other large coal companies, such as Pittston, who tried to avoid the company's agreements with the union regarding health care benefits for widows and retirees. In 1989, three years after yet another failed strike of Massey, the UMWA participated in a bitter strike against Pittston that resulted in large fines and strained relations. Ultimately, the fines were dismissed by the United States Supreme Court and the strike seemed to mobilize the union, especially after its Massey defeats, and proved once more that it was not afraid to stand up for workers and their families. $^{24}$ Massey remains largely non-union, reporting that in 2003 only 193 of its 4,428

${ }^{24}$ Ken Ward, Jr., “Trumka Hails 'Tremendous Victory for UMWA,"” Charleston Gazette, July 1, 1994; for further reading on the Pittston and Massey strikes, please see Richard Couto, "The Memory of Miners and the Conscience of Capital: Coal Miners' Strikes as Free Spaces," in Fighting Back in Appalachia: Traditions of Resistance and Change, ed. Stephen Fisher (Philadelphia: Temple University Press, 1993); for further reading on the Pittston strike, see Richard Brisbin, Jr., A Strike Like No Other Strike: Law \& Resistance During the Pittston Coal Strike of 1989-1990, (Baltimore, MD: John Hopkins University Press, 2002); Jim Session and Fran Ansley, "Singing Across Dark Spaces: the Union/Community Takeover of Pittston's Moss 3 Plant," in Fighting Back in Appalachia. 
employees (or 4 percent) were members of the UMWA. Massey cited "an increased risk of work stoppages and higher labor costs" with workers represented by the union. ${ }^{25}$

The UMWA's most recent strike began on October 22, 2004, once again against Massey Energy. The object of the union's anger is not so much Massey itself, but a system that allowed the bankrupted coal company, Horizon, which sold its Cannelton mines, to Massey to evade its contractual obligation with the union for health benefits. Union president Cecil Roberts noted that these types of bankruptcy allowances are serious American problems. He hoped that the problem would eventually be fixed by an overhaul of federal business bankruptcy laws. The union fully expects to be striking the mine through February $2005 .{ }^{26}$

The fierce anti-union sentiment witnessed throughout the southern coalfields is particularly offensive to a union that fought long, hard, and often bloody battles to gain recognition in the southern West Virginia coalfields, which then became the union's stronghold in the state. The continued growth of non-union mines in its traditional stronghold certainly hurts the union. ${ }^{27}$ It also hurt the miners for as many companies turned to surface mining, heightened mechanization, and contract labor, coal miners increasingly formed an even more expendable workforce. The loss of influence was especially important to the communities themselves. In the past, the UMWA's work had improved not only the work environment of its members, but also the work environment of all miners as well as endorsing political candidates who advocated for labor and coal communities. Learning from past experience with massive unemployment, the union currently sponsors UMWA Career Centers, Inc., to help unemployed

\footnotetext{
${ }^{25}$ Massey Energy, 2003 Annual Report (Richmond, VA: Massey Energy Company, 2004), 16, 25.

26 "Miners Rally as Union Launches Strike," Charleston Gazette, October 22, 2004.

${ }^{27}$ Peter M. Slavin, "UMW Battles for Survival Against Old Foe Massey Coal," Charleston Gazette, December 10, 1995.
} 
members and their families obtain new employment skills after coal mining layoffs. ${ }^{28}$ Often residents looked to the UMWA to have their communities' interests at heart. It remains to be seen if the present upsurge in coal demand will see any real increase in coal miner organization, especially in the southern West Virginia coalfields. Even with these obstacles, the union has continued to evolve, managing to organize workers outside of its traditional coal mining targeted recruitment, and has gained some success in those endeavors.

The UMWA's stance on mountaintop removal coal mining has vacillated between the silence of acquiescence and outrage at opponents of the process. It has followed a very precarious balancing act between protecting the interests of its members who work on these sites, underground miners, and the communities affected by MTR. Faced with ever dwindling membership roles, particularly as the industry mechanized and as surface mining became more prolific, the UMWA had little choice but to attempt to unionize these workers. Often such attempts at unionization were spurned by a workforce that worked in a far safer environment and were typically better paid than their underground counterparts. The union consistently followed a precarious policy of trying to ensure fair wages for both segments of its membership because the interests of underground miners were often antithetical to those of surface miners. In the 1970s, UMWA leadership under Arnold Miller supported the strictest reclamation of these sites, instinctively knowing that many of these jobs would go to unemployed miners, ${ }^{29}$ but the union faced stiff resistance in convincing surface miners to cast their lot with the UMWA.

Until the proliferation of MTR in Appalachia during the 1990s, the union had focused its attention on efforts to organize western surface miners. The bread and butter issues of the union

\footnotetext{
28 "A New Lease on Life: Achieving Success via the UMWA Career Centers," United Mine Workers of America Journal (January-February 2001); Joe Smydo, "Union, State, U.S. Extend a Hand to Coal Town Youth: Goal is to Fortify Communities," Pittsburgh Post-Gazette, October 3, 2004.

${ }^{29}$ Fox, United We Stand, 353-354.
} 
- safer working conditions, better health care, and higher wages - were not real issues for surface workers who already enjoyed superior working conditions and higher wages. In addition, western miners did not have a long history of bloody unionization efforts to rally around, and most were not from mining traditions. ${ }^{30}$ Most of the western surface coal miners remain unorganized by the UMWA.

Until recently, the UMWA had been conspicuously quiet regarding MTR. When addressing communities struggling in the face of a Massey MTR operation, union leadership expresses its opposition, and encourages people to fight against the operation. A 1998 editorial written by the UMWA's president, Cecil Roberts, indicated that the union strove to achieve a balance between mining jobs and environmental concerns. Unlike coal companies who often repeat that same mantra, Roberts detailed that the union was not in favor of either extreme (the environmentalists or the coal companies) which he claimed either favored outlawing all coal mining, or allowing the industry to operate without regulation or regard for community welfare. He heartily defended the union's right to protect the workers of these MTR sites, but asserted that the Union could both protect those jobs and speak up for the communities. Roberts unequivocally stated:

"The UMWA strongly believes that coal companies should not be permitted to destroy local communities in the process of mountaintop removal mining, including by blasting. Community residents with homes and farms should be protected from the consequences of such damage. The UMWA believes that there should be additional legal protections to ensure that blasting damage can be easily and completely compensated by coal companies....[W]ith regard to any property within 1-mile radius of a blast, there should be a rebuttable presumption that the blast caused any property damage."31

\footnotetext{
${ }^{30}$ Deborah Underwood, "The Ascendancy of Surface Mining over Underground Mining in the United States Coal Industry: Effects on and Issues Relevant to the United Mine Workers of America" (MA thesis, University of Montana, 1987), 27-28, Chapter 2.

${ }_{31}$ Cecil Roberts, "Responsible Mining: UMWA Wants Communities, Environment Protected," Charleston Gazette, October 12, 1998.
} 
Roberts also called for better federal enforcement of the surface mining act, and a halt to the allowance of fish and wildlife habitat and recreation lands as an acceptable post-mining use. The editorial also maintained that southern West Virginia mountains with historical significance, such as the historical parts of Blair Mountain and the Stanley family farm on Kayford Mountain, should not be mined at all. He also noted that mining provided jobs in areas where few jobs were available, and that the taxes generated by mining, including surface mining, were important sources of public revenue. Even though he maligned Massey's MTR activities in the past, Roberts also seemed to defend Arch Coal, another MTR operator, as a good and responsible corporate steward. ${ }^{32}$ Not surprisingly, some of Arch Coal's employees are union employees. Roberts did not mention Massey, Arch Coal's fiercest MTR competitor and a staunch anti-union company. Arch shrewdly allowed the unionization of many of its MTR employees. By doing this, they ensured themselves an unholy alliance with the UMWA, but one which left the UMWA unable to adequately speak out against the process now that it was bound to protect its MTR members.

This protectionist stance was seen during and after the Bragg v. Robertson case, heard by Judge Charles Haden, II. ${ }^{33}$ Soon after the judge's preliminary injunction effectively halted the expansion of Arch's Dal-Tex mine, 1,500 union miners and industry supporters marched on the state capital in protest. At risk were 387 union jobs at the Dal-Tex mine. District 17 president, Bob Phalen, spoke of Haden's decision as a worker's issue, rather than a union versus non-union issue, and declared that the ruling would cause the "economic devastation [of] the state." Those opposing MTR were painted as "extreme" environmentalists. Phalen went on to say that a line must be drawn "when extremists set out to destroy an entire industry and destroy the lives of tens

\footnotetext{
32 Ibid.

${ }^{33}$ Please see Chapter Five for further discussion of Bragg v. Robertson.
} 
of thousands of workers." ${ }^{34}$ A union once proud to speak for the coalfield communities, not just its members, showed how much things had changed when it denounced community members affected by MTR who were now suing for the enforcement of federal regulations. At least one of the plaintiffs in the case was a disabled underground coal miner and union member.

The UMWA's position in Bragg v. Robertson illustrated yet another break from community involvement by union leadership. So fervent was the union in its support of MTR mining in West Virginia that President Cecil Roberts requested a debate with Cindy Rank, one of the leading environmental opponents to MTR, to discuss why "West Virginia needs mountaintop coal mining (and mining in general) done responsibly and by the law."35 What Roberts failed to acknowledge was that the plaintiffs in the case did sue for mining to be "done responsibly and by the law," and that Haden had ruled that neither had taken place. More appropriately, the union might have discussed the very concerns of these citizens which prompted this suit and how illegal activity might be reigned in. Arch Coal had the opportunity to submit a legal application for expansion of the mine in question at any time before the injunction was handed down, but erroneously assumed the court would rule in its favor and that members of West Virginia's federal delegation would intercede on its behalf. In supporting Arch Coal in this matter, the union was in blatant denial. As a Charleston Gazette editorial stated, miner lay offs rested squarely at the feet of Arch Coal, not the residents and citizen groups that brought forth the lawsuit. ${ }^{36}$ Contacted by this author regarding the union's official stance on MTR, Roberts'

\footnotetext{
${ }^{34}$ Steve Myers, "Tension Over Mining Could Grow; Those at Rally Say They Need Jobs to Support Families," Charleston Daily Mail, March 13, 1999; Steve Myers, "Mountaintop Mining Debate Suggested: Environmental Leader Not Sure if She will Join,” Charleston Daily Mail, May 14, 1999.

${ }^{35}$ Myers, "Mountaintop Mining Debate Suggested," Charleston Daily Mail, May 14, 1999.

36 "No Favors: Why Not Mine Legally?," Charleston Gazette, July 8, 1999.
} 
response remained consistent, a need to balance good jobs, including MTR jobs, with environmental concerns. ${ }^{37}$

The union's fierce protectionist attitude of MTR operations infuriated some out-of-work underground miners. A 1999 Charleston Gazette letter to the editor pointed out some of those frustrations. The author of the letter indicated that he was one of thousands of laid-off underground union miners. He questioned the lack of UMWA publicity in the loss of these underground jobs while the union paid a vast amount of attention and media dollars over the potential loss of a few hundred jobs at Dal-Tex. The tone of his letter was pure frustration. The author clearly believed that the UMWA had created its own problems by championing MTR at the expense of underground coal miners as well as believing that if the Union had been as supportive when the underground jobs were in jeopardy, then perhaps many workers could have maintained their jobs. ${ }^{38}$ Indeed, balancing the interests of the two factions became more and more difficult for a Union trying to maintain its dignity and tradition while in desperate need of members. While the union sided with residents against its arch enemy Massey Energy, it staunchly defended MTR thereby limiting the amount of collaboration between the community groups and the union. For these reasons, the UMWA's influence in coal communities continued to diminish. Many coal community residents were no longer able to depend on the union and found themselves forced to organize their own community organizations to oppose the injustices of the coal companies, injustices that the UMWA failed to adequately recognize and address.

\footnotetext{
${ }^{37}$ Doug Gibson, United Mine Workers of America spokesperson, telephone message to Shirley Stewart Burns, October 29, 2004. Message in response to one written and one electronic inquiry by author.

${ }^{38}$ Randy Sprouse, "Reader's Forum," Charleston Gazette, July 16, 1999. It should be noted that Sprouse was apparently so disgruntled with the inattentiveness of politicos and his union to the degradation occurring at the hands of MTR mining that he formed the community action group Coal River Mountain Watch in 1998. An article in the Charleston Daily Mail detailed the media blitz supporting MTR, see Steve Myers, "UMW Launching Ad in Support of Industry; Activist Calls Spot 'Terribly Misleading'," Charleston Daily Mail, May 22, 1999.
} 


\section{$\underline{\text { Conclusion }}$}

After decades of struggle in the southern coalfields, the union is now facing opposition by the numerous anti-union coal mines operating in southern West Virginia.

For much of its existence, the union played an important role in the lives of miners, their families, and their communities. However, the United Mine Workers of America (UMWA) has recently found itself on opposing sides of many coalfield residents.

As membership and representation in the southern coalfields declined, so did the union's influence within coalfield communities. Influence continued to decrease as the newest wave of mechanization embodied in MTR forced more workers out of jobs. Wherein residents had frequently experienced the influence of the union in their daily lives, the union's new alliance with MTR often pitted it against coal community residents. Today the union continues to struggle to balance the needs of both factions of its membership. Many community residents disappointed in their treatment by MTR companies, whether unionized or not, know that they must take action if their communities are to continue. With the goal of survival as impetus, they have formed their own organizations to combat adversarial relationships with coal companies that the union, at one time, would have battled with them. 


\section{Chapter Three:}

To Dance With the Devil:

The Social Impact of Mountaintop Removal Surface Mining

"There are two roads in life, a right one and a wrong one.

There is no in-between path to take."1

Pauline Canterberry, Sylvester, West Virginia resident

As the nineteenth century gave way to the twentieth, West Virginia's rural backcounties experienced a fundamental transformation. Natural resource speculators pervaded the area, chief amongst them were coal, timber, and their handmaiden railroad industries. Throughout West Virginia, beautiful hardwood forests came crashing down until by the 1920s, nearly all of it was gone. ${ }^{2}$ Railroads penetrated the rugged backcountry to whisk the natural treasures of timber and coal beyond the state to the large cities beyond. Older agricultural communities were soon joined by the new industrial towns that dotted the region's landscape for the express purpose of providing a home for workers and their families. The repercussions of this rapid-fire change resonated throughout the southern mountains. Subsistence farmers accustomed to bartering soon found themselves usurped by wage earning laborers, toiling in the mines rather than the fields.

As the industrial age gave way to the information age, coal miners hung on struggling for their economic lives. Technology had nearly rendered them obsolete. Underground miners saw their ranks slashed as the continuous miner and longwall machinery replaced tens of thousands of men. Surface workers witnessed the introduction of twenty-story draglines which performed the work previously requiring hundreds of workers. Caught in the middle of these changes were not only the miners, but all coalfield residents. Not many alternative economic opportunities were available in these areas where coal has held the reigns of power for more than one hundred years and where shortsighted politicians have done little to advance economic diversification.

\footnotetext{
${ }^{1}$ Pauline Canterberry, interview by author, tape recording, Sylvester, West Virginia, October 9, 2003.

2 Ronald Lewis, Transforming the Appalachian Countryside, 5, 9.
} 
While many migrated from these areas, others stayed because of personal ties to their family and community. Individuals who refused to migrate were placed in the most precarious positions of all, caught between dwindling coal jobs lost to mechanization, particularly as communities transitioned to MTR mining thus hastening job losses, and the desire to protect their own homes and families from what they deemed a very unpromising future if MTR continued unabated. These social complexities pervade the southern West Virginia areas currently being mined by MTR.

Pauline Canterberry and Mary Miller live in Sylvester, Boone County, West Virginia. Sylvester is a small, incorporated town of some 195 people on the outskirts of Whitesville, West Virginia. ${ }^{3}$ The town was founded in 1952 by people who hoped that it would be a haven for those who, while making their living by coal mining, did not want to live inside a coal camp. ${ }^{4}$ The town has seen a number of coal companies on its outskirts during its nearly five decades of existence. Both Mary and Pauline noted that these underground coal companies had bosses and supervisors who lived in the town, and that those people, therefore, had a vested interest in ensuring the safety of the town. ${ }^{5}$ Then came the huge MTR operations of Massey. For the first couple of years nothing was out of the ordinary as coal trucks carried out vast amounts of coal as the other companies had also done. All of that changed in 1997 when Massey opened its Elk Run Preparation Plant just outside the Sylvester city limits. This preparation plant cleans coal derived from some of Massey's underground mines at Elk Run as well as its surface mined coal

\footnotetext{
${ }^{3}$ U.S. Census Bureau, Profile of General Demographic Characteristics: 2000, Sylvester, West Virginia, generated by Shirley Stewart Burns, using American Fact Finder, available from http://factfinder.census.gov, October 11, 2004.

${ }^{4}$ Pauline Canterberry interview; Mary Miller, interview by author, tape recording, Sylvester, West Virginia, October 9, 2003; Boone County, West Virginia, "Certificate of Incorporation of the town of Sylvester," 1952.

${ }^{5}$ Mary Miller interview; Pauline Canterberry interview.
} 
from its Progress mine. ${ }^{6}$ With Massey’s new preparation plant fully operational, the town and its residents began to experience significant problems.

The first encounter many residents have with a mountaintop removal mining operation is when they are contacted by a coal company alerting them to plans for blasting. The letter offers the homeowner the chance to have the property surveyed in case there is damage to the home or land. The purpose of the survey is to make it easier to distinguish damage resulting from blasting and damage that pre-existed. Anyone owning property within half a mile of blasting receives the letter. ${ }^{7}$ The first knowledge of MTR these homeowners often experience is when blasting begins on the worksite. Before blasting can occur, the mine operator has to have a blasting plan to protect the public from the negative impact of blasting. While highly technical, a review of these plans should reveal the time of day the blasting will occur, and how close the blasting will be to other structures. ${ }^{8}$

Once blasting commences, the effects can be felt for miles around. Often, these blasts disturb properties, separating walls and floors from one another and from the foundation, for instance, and leave huge boulder debris in yards, cause damage to individual private property, and ruined wells. Russell Elkins from Rawl, Mingo County, West Virginia, described how his windows fell out of his home directly after a Massey coal company blasted nearby. Elkins estimated that nine out of ten homes in the hollow were in some way affected by the blasting, but that the people were afraid to come forward because they or their loved ones were employed by Massey. Dickie Judy from Foster Hollow, Boone County, described the damage his home has experienced, both inside and out, due to the coal company near his home blasting on an MTR

\footnotetext{
${ }^{6}$ Massey Energy, 2003 Annual Report, 9-10.

${ }^{7}$ Mark Squillace, Strip Mining Handbook: A Coalfield Citizens' Guide to Using the Law to Fight Back Against the Ravages of Strip Mining and Underground Mining (Washington, D.C.: Environmental Policy Institute and Friends of the Earth, 1990), 69-70.

${ }^{8}$ Ibid., 70 .
} 
site, pointing to split foundations and describing shaking walls and pictures falling from the walls during blasting. When describing a multitude of damages to his church and other structures, Larry Brown from Rawl detailed problems such as cracked foundations, split windows, and ruined wells. Summarizing the problems, he noted, "It's destroying property and the state. The beauty of our state is being cut out...torn away from us."

Those distant from the blasting, in some instances miles away, are able to hear the distant rumbling as the dynamite is set off. Those closer to the blasting may experience tremors in their house and on their property. Flyrock may also result. Carlos Gore from Blair, West Virginia, related how a mountaintop removal site near his home produced flyrock the size of softballs that pelted his home and landed in his front yard. Emphasizing the danger of such flyrock, Gore commented to state DEP regulators, "If a rock this big hits you or your car or your house, you're going to have more than a headache. It's going to ruin your whole week, because there's going to be a funeral." ${ }^{, 10}$ Gore's is one of less than twenty-seven families still remaining in the small, historic community of Blair. As the mountaintop removal permits increased, the small community has been dismantled house by house, hollow by hollow. ${ }^{11}$ Similar experiences exist throughout the southern West Virginia coalfields where MTR is occurring.

Federal studies have balked at acknowledging residents' assertions that problems have occurred with blasting and MTR. One such document, the Draft Environmental Impact Study (DEIS) on MTR declared that:

"[t]he existing regulatory controls provide adequate protections from coal mining-related blasting impacts on public safety and structures including wells [and that] the existing

${ }^{9}$ All Shaken Up, interviews with Russell Elkins, Dickie Judy, and Larry Brown (Charleston, WV: Omni Productions, 1998), videocassette.

${ }^{10}$ Ken Ward, Jr., "State Environmental Officials Limit Blasting at Dal-Tex Mine: Rocks Sailing into Yards Upset Blair Residents, Charleston Gazette, August 23, 1997; Ken Ward, Jr., "Strip Mine Battle Resurfaces in State," Charleston Gazette, March 22, 1998; personal conversations between author and Carlos Gore, various dates.

${ }^{11}$ Ibid. 
regulatory programs are intended to ensure public safety and prevent damage rather than eliminate nuisances from coal mine blasting activities. Some blasting within legal limits may still constitute a nuisance to people in the general area. As with all nuisances, the affected persons may have legal recourse regarding blasting nuisances through civil action. Consequently, blasting is not considered a "significant issue" and no actions are considered in this EIS." 12

Coalfield residents tell a different story. Noise, dust and property damage associated with blasting has been a frequent complaint in the coalfields of southern West Virginia. ${ }^{13}$ In areas where blasting occurs on a regular basis, cracked foundations, loss of wells, and blown out windows are commonplace. Unlike traditional contour strip mining where blasting would last from weeks to months, MTR blasts can lasts for years thereby affecting close neighbors for years. ${ }^{14}$ While legal recourse in civil courts is an option, the residents must prove that damage was caused directly by blasting, and not through faulty construction. To do this, residents must have an independent assessment of their homes with all detailed findings and current damages. Residents within half mile of the permit area can request a blasting survey, ${ }^{15}$ but those further out are on their own. These surveys can be costly, especially in a depressed region where people have problems even meeting basic survival needs. Many can not afford this pre-assessment, and yet they can not afford to not have this pre-assessment of their homes either.

Greta Stone (a pseudonym) lives in the Oceana-Kopperston, West Virginia, area. A forty-year resident of the community, she worked in the Wyoming County school system for more than three decades. She lives within one mile of a mountaintop removal site. Huge coal trucks barrel by her house seven days a week, 365 days a year. A layer of coal dust covers most

\footnotetext{
${ }^{12}$ United States Environmental Protection Agency, Draft Environmental Impact Study (hereinafter, DEIS), Alternatives, Part Two (Washington, DC: U.S. Environmental Protection Agency, 2003), 6.

${ }^{13}$ Ken Ward, Jr., "Mining Study: Blasts not 'Significant,"” Charleston Gazette, August 3, 2003; Ohio Valley Environmental Coalition, January 5, 2004, letter, Comments on Draft Programmatic Environmental Impact Statement on Mountaintop Removal Mining/Valley Fill Activities in Appalachia: The Social and Cultural Effects of Mountaintop Removal/ Valley Fill Coal Mining (Huntington, WV: Ohio Valley Environmental Association), 6, available from http://www.ohvec.org/issues/mountaintop_removal/articles/EIS_social_cultural.pdf.

${ }^{14}$ Ken Ward, Jr., "Mining Study," August 3, 2003

15 Ibid.
} 
of the area. It is the dust and noise that cause the most problems for Greta and her husband. "Coal trucks run all day and the noise is so bad. They pass each other constantly." The coal company does attempt to sweep the streets periodically, but Greta noted that this often only stirred up the dust and created more work for her and her husband. Like many people in the area who are aware of the mining site in their backyard, Greta feels torn. "You're so concerned (about jobs), and you don't want to bite the hand that feeds you. The coal companies and timbering companies provide jobs. No one wants to see anybody put out of a job because we have to work...we have to work." Stone also related how during the controversial period of the 1970s when surface mining was hotly contested throughout the state, some students would become upset when mentioning the environmental reality of strip mining because their fathers worked on these sites. Teachers, in return, had to be extremely careful about how they approached the subject, if at all. ${ }^{16}$ Contrast yesterday's reality to today's reality where in Boone, Logan, McDowell, and Mingo counties through a collaborative effort "between the coal industry, business community and educators" teachers can obtain "grant money and educational materials" to "[create] and [implement]... a study unit based on coal." Coal Education Development and Resource of Southern West Virginia, Inc. (CEDAR) is a non-profit, volunteer corporation whose goal "is to facilitate the increase of knowledge and understanding of the many benefits the coal industry provides in daily lives by providing financial resources and coal education materials to implement its study in the school curriculum." The organization's three programs include a regional coal fair that allows students (K-12) to enter "coal projects" in Science, Math, English-

\footnotetext{
${ }^{16}$ Greta Stone, conversation with author, Oceana-Kopperston, West Virginia, May 10, 2004.
} 
Literature, Art, Music, Technology-Multi Media, and Social Studies. Cash prizes are awarded. ${ }^{17}$ Similar programs focused on the environment or a diversified economy do not exist.

The noise and dust created from the constant coal truck haulage also poses certain problems in these communities. In 2003, the legal weight for hauling coal in fifteen southern West Virginia coal counties increased to 120,000 pounds from the previous 65,000 pound limits. The roads in many of these areas are very narrow and even at the previous rate of 65,000 pounds, numerous accidents between the coal trucks and coal community residents has resulted in the inevitable deaths of citizens unfortunate enough to wreck with these behometh machines. Many individuals in these areas were against raising these limits, fearing for their safety. They know that the roads and bridges in their neighborhoods were not meant for so much weight and they have seen the results of illegal overweight trucks running through their neighborhoods' demolished roads that are rarely, if ever, repaired and unnecessary deaths. ${ }^{18}$ Most of these roads should not have monstrous vehicles traveling them. Such arguments were used by those against the tonnage increase, but their protests went unheard and West Virginia's 2003 legislature increased the amount to 120,000 pounds for fifteen coal counties and for many of the roads within these areas. This should have surprised no one familiar with the history of overweight coal trucks in the southern coalfields. The trucking industry indicated that they were only competitive for contracts if they hauled over the legal limits. Otherwise, they risked being underbid for contracts. Of course, if the truckers were caught hauling illegal loads, it was the

\footnotetext{
${ }^{17}$ West Virginia Coal Association, Coal Education Development and Resource of Southern West Virginia, Inc. (CEDAR) (Charleston, WV: West Virginia Coal Association, 2004), available from http://www.wvcoal.com/current_issues/index.asp.

${ }^{18}$ Dan Radmacher, "Coal Truck Bill is an Economic Disaster for West Virginia," Charleston Gazette, February 28, 2003. The author has had numerous such close calls in the coalfields of southern West Virginia and has been driving as well as been a passenger in cars that were run off the road by huge coal trucks heaped with coal trying to maneuver the very narrow roads in these valleys. Longer reaction times would have been disastrous. It should be noted that the truck drivers did not appear to be doing anything malicious. The roads are simply not large enough to accommodate the large coal trucks and any size vehicle. The coal trucks, quite simply, must use more than just one lane in order to maneuver the steep, mountainous terrain.
} 
truck company that was responsible for the fine, not the coal company. Allowed to run illegally for decades, many truck companies were vulnerable when prior to passing the new weight limits, the state began to crackdown on overweight coal trucks. It is common knowledge in the industry and coal communities that these trucks have run illegally for at least twenty years with authorities turning a blind eye. ${ }^{19}$ Having their illegal activity ignored for more than two decades led to the purchasing of larger trucks to also run illegally and the state would not want to hurt businesses, so the illegal activity was allowed to continue. Even when the state tried to address the situation, in late 2001, through increased fines on the overweight trucks, it was met with resistance from truckers in the southern coalfields who were effectively shut down for several days because of enforcement. Caving in to pressure, the state continued its enforcement efforts, watered down, and in the end, the legislature made legal activity that had been occurring illegally for decades. ${ }^{20}$

Perhaps the best example of the consequences of hauling coal in huge trucks and the noise and dust it creates is the town of Sylvester, West Virginia. The town experienced these problems first hand. So troublesome was the dust in Sylvester that in 2001, 154 of the town's residents filed a lawsuit against Elk Run Coal Company, a subsidiary of Massey Energy. Mary Miller related, "you're a prisoner in your own home, breathing this coal dust 24 hours a day."21 In what was for many an amazing turn of events, Boone Circuit Judge E. Lee Schlaegel, Jr., ruled against Massey Energy and declared that the coal company must contain the dust that was polluting the town of Sylvester or cease operations. Massey Energy complied by erecting a huge nylon dome over their preparation plant. Massey had originally asserted that the pine trees they

\footnotetext{
${ }^{19}$ Tara Tuckwiller, "Lighten Up, Haulers say Coal Truck Owners Hoping Legislators Ease Weight Limits: Latest State Crackdown Could Close Their Doors, Company Officials Fear," Charleston Gazette, November 4, 2001; Gavin McCormick, "Wise Names Overweight Truck Panel Members," Charleston Gazette, April 4, 2002.

${ }^{20}$ Gavin McCormick, "Wise Names...Panel Members," April 4, 2002

${ }^{21}$ Mary Miller interview. For more on this particular legal case, please see Chapter Five.
} 
had planted in front of the plant were enough to keep the dust to a minimum. The trees are small in stature and in no way could have remotely cleansed the area. The dome worked better, but it has ripped twice since its construction and had to be replaced. ${ }^{22}$ Today, the town has a consistent film of dust over the entire area. While interviewing Miller and Canterberry, the author accompanied them on a tour of their town. The pair showed the author the extent of the dust problem in Sylvester. The author used a camcorder and camera to document the day. The first home Miller and Canterberry visited was out of sight of the preparation plant. At first glance, dust could not be discerned, but upon further inspection a definitive film of coal dirt blanketed the home's back porch furniture. Even furniture that had been covered had coal dirt underneath. The owner of the home stated that she had paid men to come with a power hose and spray down the entire house a few weeks before our visit. She showed the author where the coal dust had already gathered on the home. All of the women stated that the coal dust problem while not as bad as it had been before the lawsuit, still was a problem. All were concerned about the possible health hazards the coal dust presented. ${ }^{23}$

The process of cleaning coal is a dirty one. Coal is washed to remove the ash. ${ }^{24}$ What is left over is a thick, gooey substance known as slurry. This slurry is held back by an impoundment that holds vast amounts of the impurities and wastewater left over from the washing. ${ }^{25}$ These impoundments typically hold millions of gallons of slurry and are frequently hundreds of feet deep. One such impoundment is the Brushy Fork impoundment that was built only four to six miles from the Sylvester-Whitesville neighborhood. This impoundment, owned

22 "Replacement Dome Rips at Massey Plant," Charleston Gazette, April 24, 2003.

${ }^{23}$ Personal contact with Mary Miller, Sylvester, West Virginia, October 9, 2003; personal contact with Pauline Canterberry, Sylvester, West Virginia, October 9, 2003.

${ }^{24}$ Robert Meyers, Coal Handbook (New York: M. Dekker, 1981), Chapter 6.

${ }^{25}$ Ibid, Chapter 6; Jann Vendetti, “Mining: Storing Coal Slurry,” Alexandria, VA: American Geological Society, available from http://www.geotimes.org/dec01/NNcoal.html, November 1, 2004. 
by Massey Energy, is 900 feet high and will hold 8.168 billion gallons of slurry once it is completed. This will be the largest such impoundment in the nation. ${ }^{26}$ One of the main fears voiced by Sylvester residents is the exit route on file at the West Virginia Department of Environmental Protection in case of a break which suggested an exit route that has the community leaving towards the flow of the impoundment break. ${ }^{27}$ Noted Mary Miller, "[T]hey are...trapping us down here in these valleys with no hope of escape. ${ }^{, 28}$ Hydrogeologist Rick Eades performed a survey of the Brushy Fork Impoundment. He, too, was alarmed that the evacuation plan prepared for Marfork, the A.T. Massey subsidiary that owns the impoundment, instructed the citizens of Sylvester to travel four miles into the path of any sludge release. He called for a new emergency evacuation plan to be constructed, one that would not have inhabitants driving into the danger. Eades related how an impoundment break in Inez, KY, prompted him to reevaluate his concerns. ${ }^{29}$ In October 2000, a Massey Energy slurry impoundment in Martin County, KY, broke through the underground mine it rested above. From there, the 300 million gallons of slurry poured through local creeks, eventually making its way to the Tug Fork of the Big Sandy River, on the border between West Virginia and Kentucky, as well as into the Ohio River. ${ }^{30}$ While no human life was lost, one hundred miles of streams were polluted and any life forms in its path were effectively obliterated. ${ }^{31}$ Eades noted that consultants who work for the coal companies are under a huge amount of pressure to provide

\footnotetext{
${ }^{26}$ Robert C. Byrd National Technology Transfer Center (NTTC), Wheeling Jesuit University, West Virginia University and the National Energy Technology Laboratory, "Coal Impoundment Location and Warning System," available from http://www.coalimpoundment.com/locate/impoundment.asp?impoundment_id=1211WV04-40234-02, October 30, 2004.

${ }^{27}$ Rick Eades, Brushy Fork Slurry Impoundment - A Preliminary Report (Huntington, WV: Ohio Valley Environmental Coalition, 2000), 17.

${ }^{28}$ Mary Miller interview.

${ }^{29}$ Eades, 13; "UMWA launches community education campaign about Massey's Brushy Fork Impoundment," UMWA Journal, January-February 2004.

${ }^{30}$ Ken Ward, Jr., "Criminal Probe Is Ongoing in Coal Mining Dam Failure in Kentucky," Charleston Gazette, May 12, 2004.

${ }^{31}$ Jack Spadaro, "Mountaintop Removal Mining Practices Must Change or Ecosystem will be Destroyed," Charleston Gazette, February 21, 2005.
} 
data that is favorable to the consultant's client. He asserted that "consultants must find the 'least-case scenario' of environmental risk, somewhere within their credible methods, to enable coal companies to do whatever they want to do." He did not make such assertions lightly noting that he himself had been employed as a government and commercial consultant for 16 years. ${ }^{32}$ He was concerned with claims that the Eagle Fork Mine had enough coal left in the mine's pillars to support the "additional load" from the Brushy Fork slurry impoundment. Constructing impoundments over underground mines could thus leave the impoundment vulnerable to breakthroughs, putting the communities near the impoundment in direct harm. Eades' concern stemmed from the fact that coal companies would never leave that much coal in a mine, and to suppose that the company had any prior knowledge that a slurry dam would be built above it is illogical. $^{33}$

The fear of impoundments and dust problems grip the entire town of Sylvester. Both Miller and Canterberry spoke of the problems encountered by the workers of the now closed Sylvester grade school. Coal dust blanketed the cooks' equipment with so much dust that the cooks were forced to wash the equipment again before using it. Finally, the cooks decided to just store their pots and pans in plastic bags to keep from having to wash it twice. ${ }^{34}$ Miller commented that just a year before the local elementary school shut down, housing grades k-8, the school had conducted emergency evacuations of the students in case of a slurry impoundment break. Officials at the school timed the children as they moved from the school to the tallest knoll in the area that most of the town would be clamoring to reach should an actual slurry

${ }^{32}$ Eades, 11; "UMWA launches community education campaign," UMWA Journal, January-February 2004.

${ }^{33}$ Eades, 11 .

${ }^{34}$ Mary Miller interview; Pauline Canterberry interview. 
impoundment break occur. ${ }^{35}$ Pauline Canterberry added, “There's children in these valleys, too. I might be old and ready to go, but a lot of these people are not. They still got life ahead of them." $" 36$

Another recurring concern of inhabitants of the region was that their people, particularly their young children, their communities, and homes were not deemed worthy of saving by the politicians and coal companies. Anger was apparent when each spoke of the potential loss of life and the hazards the children in their towns were encountering, hazards the community had not faced before. Some children are so frightened of flooding and slurry breaks that when it rains they sleep fully clothed. The same problem occurred with the elderly who also experience a fear of flooding and sudden impoundment failure when it rains as well as the incessant loud noise associated with blasting and coal trucks. ${ }^{37}$ The problems associated with the stoker plant above Sylvester and the dust it created was severe enough to cause the Boone County Board of Education to change its plan of consolidating Whitesville and Sylvester Elementary. Rather than maintain the newer Sylvester facilities, the board chose to close the Sylvester school and consolidate it with Whitesville Elementary. ${ }^{38}$ Whitesville Elementary has been repeatedly flooded and is older than the Sylvester school. ${ }^{39}$

Unfortunately, Sylvester and Whitesville are not unusual cases in the southern West Virginia coalfields. Huge coal slurry dams have been built above schools elsewhere, and in some instances schools have even been built in valleys below a dam. In Wyoming County, for example, the new Wyoming County East High School was built less than two miles from the

\footnotetext{
${ }^{35}$ Mary Miller interview.

${ }^{36}$ Pauline Canterberry interview.

${ }^{37}$ Judy Bonds, interview by author, tape recording, Sylvester, West Virginia, October 8, 2003; Patty Sebok, interview by author, tape recording, Whitesville, West Virginia, October 8, 2003.

${ }^{38}$ Boone County Board of Education, Reasons Supporting Data - Executive Summary of Consolidation of Sylvester Elementary and Whitesville Schools for Boone County Schools (Madison, WV: Boone County Board of Education, 2002), 37.

${ }^{39}$ Pauline Canterberry interview; Mary Miller interview.
} 
high hazard Joe Branch impoundment. Like the Martin County, Kentucky, impoundment that dumped in excess of 300 million gallons of coal slurry into tributaries that flow into the Tug Fork, ${ }^{40}$ the Joe Branch impoundment was partially built over underground mines. In addition, Joe Branch had been constructed at least twelve years prior to the building of the new high school. The emergency evacuation plan that Consolidation Coal Company submitted to DEP indicated that if a "fair weather break" were to occur, the slurry would crest at twenty-one feet at New Richmond (home of the school and retirement village), eleven feet at Pineville, 11.4 feet at Mullensville, and 11.4 feet at Marianna. "These communities are 2.4, 7.7, 13.7, and 17.9 miles, respectively, from the impoundment." The high school consists of nearly 600 students, faculty and staff and is downriver from any potential breakthroughs, and as illustrated by the company's own evacuation plan, would be devastated should a breakthrough ever occur. (The company is quick to note in its evacuation plan the unlikelihood of this ever occurring, in spite of the dam's

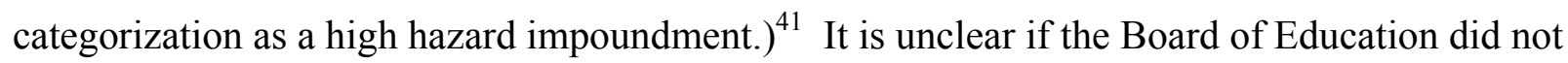
realize the danger existed, or simply chose to ignore the fact when it decided to construct the school in its present location. Also downstream from the impoundment is a retirement home and several small communities. The town of Pineville, county seat for Wyoming, a mere seven miles from the site, has a high potential to also be negatively impacted by any breakthroughs. ${ }^{42}$

The danger associated with these impoundments being so close to communities and schools is real and deaths of schoolchildren due to such impoundments is not speculation. In Aberfan, Wales, on October 21, 1966, a similar impoundment looming above the coal town

\footnotetext{
${ }^{40}$ Ken Ward, Jr., "Mine Spill on Tug Underscores Dam Concerns," Charleston Gazette, October 13, 2000; Ken Ward, Jr., “Criminal Probe Is Ongoing,” Charleston Gazette, May 12, 2004.

${ }^{41}$ Consolidation Coal Company, Monitoring and Emergency Warning Plan and Procedures for the Joe Branch Coal Refuse Dam (Welch, WV: Department of Environmental Protection, 2003), 12, available from http://www.coalimpoundment.org/EmergencyPlans/1211-WV4-0709-01.pdf

${ }^{4}$ Ibid., 12; GIS mapping also illustrates this.
} 
spilled over its boundaries and landed in the town of Aberfan below. The disaster resulted in a loss of 144 people, 116 of them schoolchildren who had met their death after the rushing sludge completely covered three classrooms of their school. ${ }^{43}$ Disasters such as Aberfan should prove as cautionary tales for those constructing coal dams above communities. The British government did create warning documents and distributed them to interested parties both inside and outside Britain. One of those interested parties was the coal company operating above Buffalo Creek, West Virginia. The company had even consulted with British experts. Yet in 1972 Buffalo Creek was virtually destroyed and 125 people died when a coal dam above the community collapsed. Only after this loss of life would coal dam failures receive attention in the U.S. ${ }^{44}$ All of the problems associated with MTR notwithstanding, there is an unquestionable need for jobs in an area where the unemployment rate runs as high as 11 percent, representing some of the highest numbers in the state. The recent loss of thousands of residents in search of work has resulted in a population comprised mostly of the elderly and disabled. The few remaining working age individuals lucky enough to have jobs work for the coal companies, the school system, or the supporting welfare system. Well paying jobs are sparse in the coalfields, and while there are many residents opposed to MTR in the southern West Virginia coalfields, there are others who staunchly support it. Some of the most vocal protectors of the practice are the workers whose livelihood depends on the continuation of MTR. In 1998, when Arch Coal's Dal Tex mine was trying to secure a controversial expansion permit, workers at the operation showed up in droves at a public DEP hearing. They spoke of the need for good paying jobs in their area and of the high unemployment in their towns. They were urged on by the company which inserted into their employees' paycheck envelopes a notice that, "There will be people

\footnotetext{
${ }^{43}$ Iain McLean \& Martin Johnes, Aberfan: Government \& Disasters (Cardiff, Wales: Welsh Academic Press, 2000), 22.

${ }^{44}$ Ibid., 90, 234-235.
} 
there who don't want this permit issued. They don't care about your job. Please attend this hearing and show that you support the future of our jobs here at Dal-Tex. Encourage your family and friends to join you. Arrive early to get your 'I'm proud to work at Dal-Tex' T-shirts while supplies last." ${ }^{25}$ One miner, a resident of Boone County, employed at the Logan County mine asked, "What are we going to give the next generation to live on? How are they going to make it? What are we going to do for jobs for our families?" Carlos Gore, a resident of Blair asked the supporters how many of them lived in the area where the MTR was taking place. No one in the audience resided in Blair. Gore responded that there was something wrong with that scenario. Gore then asked everyone who did not live in the area to raise their hand. His request was met with a flurry of hands in the air. Gore then emphasized, "We're not trying to shut you people down. We've got rules and regulations that these (DEP) people are supposed to enforce. That's all we want." Even the president of the local UMWA appeared at the meeting in support of the community. He tried to calm the audience down and explain that the residents wanted the mining to be done according to law and that the company had an obligation to either mine around the residents or buy them out at a reasonable price. ${ }^{46}$

Still, those depending on the mine to support their families were not easily consolable. Noting that the mines provided one of a very few avenues to secure a livable wage, a miner at Hobet described how his household consisted of ten people, including a son and daughter-in-law who traveled to Charleston every day for $\$ 7$ an hour jobs. He asked a very good question, "What are we going to do for jobs?"47 It was a question that neither state nor federal politicians have adequately addressed. Community leaders in the affected towns were just as adamant as the

\footnotetext{
${ }^{45}$ Ken Ward, Jr., "Miners Pack Hearing to Support Strip Permit: Area Needs the Jobs, UMW Member says," Charleston Gazette, May 6, 1998.

${ }^{46} \mathrm{Ibid}$.

47 “Miners Outnumber Others at Mountaintop Removal Meeting," Charleston Daily Mail, May 6, 1998.
} 
MTR employees. An administrator for the Logan County Commission declared that there was no other way for the county to support itself except through the coal industry, stating, "If the mining process is stopped or impeded, Logan County would suffer devastating consequences. The county commission is not saying coal mining is perfect. But we cannot lessen the degree of dependence on coal that currently exists. ${ }^{, 48}$

Other industries dependent on MTR also were quite vocal in their support and suspicious of the environmental impact of the process. Stephen Walker, the president of Walker Machinery, said, "Do not blame the coal industry for water-quality problems in Southern West Virginia today. Modern coal mining does not pollute." Coal industry representatives were indignant. Bill Raney, lead lobbyist for the West Virginia Coal Association, told EPA representatives at a Logan County hearing, “Today's hearing isn't about streams. It's about jobs, and families and kids, and a way of life."49 At this hearing, however, opponents of MTR far outnumbered proponents. Still, proponents at the meeting were especially vocal. Rather than addressing legitimate concerns posed by opponents of MTR, one union member working for Arch Coal lashed out at opponents and questioned their legitimacy as functioning community members when he commented, "Most of the people who are doing all the talking couldn't tell a dozer from a loader. Most of them are on a check or too old to have a family to raise." A company manager added, "All we have are Chicken Little environmentalists claiming the sky is falling, and they have a sympathetic press to help their cause." Opponents implored the EPA to ignore the pleas about jobs and to do their job of enforcing the law and protecting the environment. Again at this meeting, Carlos Gore while understanding the workers' desires to maintain their jobs, was vehement in his right to protect his home: "You put a pond and valley

\footnotetext{
${ }^{48}$ Ken Ward, Jr., "EPA Gets Earful on Mountaintop Mining: Supporters of Practice Outnumber Opponents at Hearing in Logan," Charleston Gazette, October 25, 1998.

${ }^{49}$ Ibid.
} 
fill in my hollow. I had two streams running, and I had well water. Now I don't have anything. I've got a right to live there. I lived there before the mountaintop removal came in, and I'll be there long after it's gone." ${ }^{50}$ Supporters of MTR expressed frustration and anger with what they perceived as flawed priorities. Terry Vance, a vocal proponent and employee at an MTR mine stated, "You need to take a good look around at what you're impacting. We're people, not crawdads or spotted salamanders.... We're not going to go into the ranks of the unemployed quietly." 51

Workers and others dependent upon the continuation of MTR for their livelihood sometimes used violent rhetoric when speaking of judicial attempts to monitor MTR. One operator of a local trucking company commented on Judge Haden's decision to halt the expansion of the Dal-Tex site, "It could get ugly. I'm surprised that some of these guys that have lost their jobs haven't taken it into their own hands with this judge." ${ }^{.52}$ Tensions became so severe that in September 1999, when trying to commemorate the Battle of Blair Mountain, a group including long-time West Virginia political mainstay Ken Hechler, was attacked by proponents of MTR who erroneously blamed the re-enactors for lost jobs. Acting more like the company thugs who historically strong-armed union members than actual union members, laid off UMWA workers and others pelted the re-enactment group with eggs and members of the reenactment group were kicked, had signs ripped from their hands, eye glasses broken, and Ken

\footnotetext{
${ }^{50}$ Ibid.

${ }^{51}$ Ken Ward, Jr., "UMW Members Protest Mine Ruling," Charleston Gazette, March 6, 1999. While it is true that the lawsuits brought against the coal companies rely largely on arguments that focus on damage afforded the environment, plaintiffs have realized that the most effective arguments are not arguments dealing with the destruction of their personal property, but dealing with the destruction of the environment in general using one of a number of federal laws against such damage.

52 Steve Meyers, "Tensions Over Mining Could Grow; Those At Rally Say They Need Jobs To Support Families," Charleston Daily Mail, March 13, 1999.
} 
Hechler himself was slightly injured. ${ }^{53}$ They would have been better served to lay their anger with the company who failed to obey the law and that used a practice that through its quick extraction methods hastens the end of coal. ${ }^{54}$

Coal industry propaganda was able to convince some underground miners that any ruling against MTR (or enforcement of laws regarding MTR and, in turn, enforcing the law which made certain valley fills illegal) would lead to an eventual end to underground mining. In truth, however, experts have concluded that Haden's ruling would not have affected that many underground mines. Still, the fix was in and had some underground miners on the defensive. One underground miner commented, "Until we quit letting the environmentalists come in and tell us what we can and can't do, we aren't going to have any mining." 55 Terry Vance commented that he and his family lived near an MTR site and that it was not hazardous. If it had been, he would have moved his family. His opinion was in stark contrast to his Logan County neighbors that filed a lawsuit against the damage the process was having on their property. One electrical engineer for Arch Coal, and a native of Logan County, commented that streams at the foot of one of his company's valley fills was clearer than the ones he had grown up around. He went on to suggest that communities focus on cleaning the sewage out of the streams instead of coal refuse. ${ }^{56}$ Still, others living in the shadow of MTR contend with rivers, like Coal River, that are so polluted that they have earned a place on the most endangered rivers list.

Clearly, those who stand to lose their jobs if MTR is halted or curbed have an investment in its continuation and will do whatever is in their power to ensure its longevity. These

\footnotetext{
53 "Violence Logan, Ravenswood," Charleston Gazette, September 2, 1999; Dan Radmacher, "Union Members Become Blair Thugs," Charleston Gazette, September 3, 1999.

${ }^{54}$ Radmacher, "Union Members Become Blair Thugs," Charleston Gazette, September 3, 1999.

${ }^{55}$ Greg Stone, “Miners Lament Lost Jobs, Lack of Help,” Charleston Gazette, September 7, 1999.

${ }^{56}$ Brian Bowling, "Logan Residents Speak Out: People Angry Over Ruling that would Hobble Mining," Charleston Daily Mail, October 22, 1999.
} 
individuals do not seem to realize that while MTR does provide a few high paying jobs, these jobs are not typically for the long run and the coal on these sites is obtained so quickly that it is mined out far in advance of traditional methods of mining. Balancing jobs and the environment has always been a tenuous endeavor for coal communities, but with MTR it has become even more so.

Religion is a cornerstone of community, and that is especially true in rural areas of southern West Virginia. By 1999, in a rare political move, Methodists, Catholics, Episcopalians, Lutherans, and Presbyterians all passed declarations opposing mountaintop removal mining. ${ }^{57}$ Although important, these pronouncements are not assertive enough in their unified opposition to enact any real social change. Therefore, members of these communities, whether they belonged to religious organizations or not, created their own safe harbors, free spaces, for the community's greater good.

Many of the residents have never been involved in protests or lawsuits, and yet many of them have felt compelled to join groups that give them the possibility of having their voices heard. Residents found little respite in the political process and the union now had allegiance with the very mode of industry that was destroying their communities. Given such circumstances, it is not surprising that some residents formed community groups to confront shared problems. Having no real safe space to air their grievances and no real outlet for their voice, individuals began creating and using free spaces in their own neighborhoods. Free spaces are "environments in which people are able to learn a new self-respect, a deeper and more assertive group identity, public skills, and values of cooperation and civic virtue., ${ }^{, 58}$ Further

\footnotetext{
${ }^{57}$ John McFerrin, "Mountaintop Removal is Harmful Tool of Dying Industry," Charleston Gazette, January $18,1999$.

${ }^{58}$ Sara Evans and Harry Boyte, Free Space: the Sources of Dramatic Change in America (New York, NY: Harper \& Row, 1986), 17.
} 
expanding on this idea, historical free space, as defined by political scientist Richard Cuoto, builds on the original concept to include a "sense of connection with past or other current effort to achieve dramatic change, allowing the understanding of democratic efforts as being related and not isolated." ${ }^{59}$ Free spaces provide people an intimidation free environment where they can express their beliefs and brainstorm new ideas without fear of retaliation from those who hold the power. Free spaces are few and far between in the southern West Virginia coalfields. Experiencing a history of oppression at the hands of coal companies and the politicians who favor coal companies, many residents of the southern coalfields have been adept at creating "free spaces."

In the coalfields of southern West Virginia, residents have created free spaces to build a collective voice in their quest to protect their homes and environment from encroaching mining. Two of the most vocal of these groups are the Ohio Valley Environmental Coalition (OVEC), and the Coal River Mountain Watch (CRMW). Formed in 1987, OVEC hoped to protect the environment of West Virginia and parts of Ohio and Kentucky through education, grassroots organizing, and media efforts. Presently, the organization's main focus is mountaintop removal coal mining. Coal River Mountain Watch was formed in 1998 by a group of concerned citizens in the Whitesville, West Virginia, neighborhood. Originally headed by laid off underground coal miner Randy Sprouse, the organization hoped to organize residents of Whitesville and the surrounding countryside who were directly affected by mountaintop removal into a vocal coalition. Both organizations have their own newsletters to address the organization's current campaigns. OVEC's Winds of Change (formerly e-notes) and CRMW's Messenger are free to

\footnotetext{
${ }^{59}$ Richard Cuoto, "The Memory of Miners and the Conscience of Capital: Coal Miners' Strikes as Free Spaces," in Fighting Back in Appalachia: Traditions of Resistance and Change (Philadelphia: Temple University Press, 1993), 165-194.
} 
the public. In the January/February 2004 edition of the Messenger, articles can be found discussing concern over coal slurry impoundments and to alert readers to a proposed expansion of a current mountaintop removal mining permit.

Coal River Mountain Watch is a particularly impressive entity as it is stationed in the middle of some of the most active MTR sites in the state and is home to some of the most contentious struggles over MTR. The individuals that organized CRMW have remained committed to the protection of their communities. Knowing that there is strength in numbers, it gives individuals a collective voice to what otherwise would have been fragmented individuals. Through their organizational efforts, protests, and educational activities, CRMW acts as a free space for its community members. At present, Julia (Judy) Bonds is the vocal director of CRMW. So effective has Bonds efforts proven that she has become nationally and internationally recognizable among American environmental activists. In 2003, Bonds won what has been called the Nobel Award for the environment, the Goldman Prize. Her passionate fight against MTR climaxed in 2001 when her family history came full circle. Six generations ago, her grandfather had been the first person to move into Marfork Hollow. Judy Bonds was the last person to leave Marfork, and the last generation of her family to live in the hollow, after being driven out of Marfork Hollow because of MTR. Bonds detailed how holding out was sometimes a dangerous venture for her. She spoke of being "run off" the narrow hollow roads into ditches by supporters of the mine. Bonds spent the first forty-eight years of her life in what she described as an ideal place to raise children, to live, and to die. Bonds commented that there had been continuous mining on Marfork Hollow for decades, but it was not as intensive or the effects so devastating environmentally. She commented that with MTR the changes that began after 1993, when Massey Energy began actively moving people out of the hollow and began its 
intensive MTR operations there, escalated and she watched her small town die, figuratively and literally.

"When they first moved in there, we had a thriving community. It wasn't as thriving and prosperous as it was when I was a child because of the employment factor in this area, but it was still a thriving community with children and, of course, people that were retired lived there and it was still a thriving community. We had our little store that was always there - the Pantry Store, but I noticed people started moving out...the houses at the head of the hollow first from Marfork and Birch....Old Man Pop Aliff was the last house in Marfork, and he did not want to move. They moved him out $\mathrm{b} / \mathrm{c}$ he was living on company land. He had a lifetime lease. He lived six months after he moved. Six months after he moved. He was heartbroken. Certain people there that didn't own their own land that was just leasing land, they were the first people to be moved out."60

She also talked of watching family cemeteries being disinterred and moved to other

places. These loved ones were lucky, she said, as other cemeteries had been pushed into valley fills. ${ }^{61}$ Both Pauline Canterberry and Mary Miller relayed similar stories. ${ }^{62}$ Regardless of how the graves are removed, the upheaval of what was thought to be "final resting places" can result in traumatic stress situations for those left behind.

Bonds witnessed the annihilation of her small community as one by one the families sold out to the coal company as the mountaintop removal operation came closer and closer to their homes. The majority of people in the hollow owned their own land, but trickled out one by one as the incessant blasting, noise, and coal dust permeated their hollow, driving them out to quieter, more stable locations. Bonds talked of her amazement at the ease in which the company tore down once vibrant homes.

"There was a beautiful home there that Harry and Cheryl Dickens owned. A beautiful brick home and of course they sold, too. Everybody started moving out. The closer you were to their mining prep plant the more people moved out. I remember after they bought that house they brought a backhoe over there and just took the backhoe, I remember the handle of the backhoe, the shovel part of it just...stuck it in the middle of that house and just pulled it back and that house

\footnotetext{
${ }^{60}$ Judy Bonds interview.

61 Ibid.

${ }^{62}$ Pauline Canterberry interview; Mary Miller interview.
} 
just crumbled. That was so strange. I don't understand how they can do anything like that, you know. It was a beautiful home and it crumbled, crumbled and it was gone in the matter of an hour. It was gone.... It was all just completely gone."

Marfork Hollow no longer exists except in the minds of former residents. Excluding one family cemetery, the rest of the hollow has been consumed by MTR. Some changes seem subtle, but are actually drastic. Bonds talked of how the mountains provided protection from the sun, wind, and floods. As the mountains have dwindled, so has that protection. The company quietly accumulated acreage. The process began and the damage started before the residents realized what was happening. Bonds cites late 1997 and early 1998 as the period when she first became aware that the mining had begun its slow encroachment on her home. Bonds related how the company put up cameras along the mine to monitor the activities near the company's property.

"The camera they had pointed at the house sitting in front of me and one right up above my house. Legitimately they could say that they had the camera on the one in front of [me] and on [their] property. They bought up around me....So it was an intimidation factor."

In less than four years, she had moved from her ancestor's homeplace. Bonds noted that she had not wanted to leave, but that "the last blackwater spill...came right up to the bank of our creek that was right in front of our house." Combined with the noise, safety issues, and dust problems and with family members frantically encouraging her to leave, she packed up and moved out of the hollow in $2001 .^{63}$

When Massey first moved in, company officials addressed a town meeting where they met with community residents and assured them that Massey would be a good corporate neighbor. Many of the community residents were not convinced since they had already heard from neighboring communities that Massey was not a good neighbor. While not a perfect relationship, the previous underground coal company, Armco Inc., was regarded as more

${ }^{63}$ Judy Bonds interview. 
sensitive to its workers and the community than either Massey or Peabody. Armco managers lived in the area which helped to create a sense of community between the company and the town, and made the company more mindful to the effects the mining had on the community. Contrast that with Massey Energy which has no high level officials living in either Whitesville or Sylvester. Bonds noted that when Peabody purchased Armco, one of the first speeches made by a company official to some new employees was how it was not like Armco, and made it clear that it was there to "make a profit," not to "help the community." "64 Unlike Armco, which had a yearly picnic for all of its employees, Peabody's picnics were for its bosses only. ${ }^{65}$ Prior to the onslaught of MTR, the underground coal companies like Armco had an unwritten policy of doing more neighborly things such as sending cards and food to employees and their spouses when a loved one died. With Peabody and Massey civic gestures no longer occurred. ${ }^{66}$ Now, the companies were large, multinational corporations directed from distant headquarters and too removed from the community to entertain such practices.

All informants who discussed this topic with the author repeatedly lamented the loss of the commons. All mentioned the hunting, fishing, berry picking, herbal medicinal gathering, ginsenging and other activities that have been either curtailed or completely obliterated because of MTR. Many noted even the streams that were not filled in by a valley fill had been rendered unusable by pollutants from mining or slurry ponds. All of them mentioned problems with noise from MTR sites, including the massive number of trucks traveling on narrow roads previously

\footnotetext{
${ }^{64}$ Ibid.

${ }^{65}$ Patty Sebok interview.

${ }^{66}$ Ibid.; Judy Bonds interview.
} 
traveled by locals and were not designed for heavy traffic. All experienced problems with dust. Finally, they all noticed an increase in flooding since MTR came into their areas. ${ }^{67}$

These were not isolated comments. Throughout the southern coalfields where MTR is taking place, residents have had similar experiences. In a written response to the DEIS, the Ohio Valley Environmental Coalition presented collected responses from coalfield residents to present to the government. Respondents also spoke of the destruction of the commons once used by multiple members of a community, as well as increased flooding problems. One man commented, "We live in fear. The whole hollow is in a state of anxiety now every time it floods." The same OVEC document noted how people in these affected communities had lost insurance on their homes and in some cases, how the homes had been condemned. Residents' homes have endured cracked foundations, walls and ceilings; destroyed water wells, and overall decreased valuations of home. ${ }^{68}$ Mary Miller related how the value of her home had fallen from $\$ 144,000$ to $\$ 12,000$. Miller's home is a beautiful, large brick home with hardwood floors throughout. In a moderate to large city, the Miller home would certainly be appraised at a far higher value than $\$ 144,000 .^{69}$ Miller personally accounted the lower appraisal to the extensive mining occurring near her home, particularly the huge preparation plant, complete with nylon dome, that sits just behind her home and that can be seen from her well maintained lawn. ${ }^{70}$ Her community also has experienced a decrease in population, and has recently suffered the closing of their area elementary school.

West Virginia's history of outmigration has vacillated in times of boom and bust. Earlier outmigrants traveled to the manufacturing centers of the Midwest, particularly Ohio and Illinois.

\footnotetext{
${ }^{67}$ Ibid; Pauline Canterberry interview; Mary Miller interview; Greta Stone conversation; Prudence Coleman (pseudonym), conversation with author, Matheny-Jesse-Glen Fork area, WV, August 10, 2004.

${ }^{68}$ Ohio Valley Environmental Coalition, letter, 4.

${ }^{69}$ Ibid., 53; Mary Miller interview.

${ }^{70}$ Mary Miller interview.
} 
A lack of good paying jobs for highly educated people has also created a drain as many highly educated West Virginians have left for places like Virginia, Pennsylvania, Ohio, North Carolina and South Carolina in search of jobs. ${ }^{71}$ The lack of economic diversification has exacerbated the exodus by educated citizens just as mechanization drained the blue-collar workforce once employed in the coal mines.

In 1951, West Virginia coal mines produced 163,448,001 tons of coal and employed more than 100,000 people. In 2002 , the state's mines produced slightly more than the 1951 amount at 163,896,890 tons of coal. The southern coalfield region lost 15,094 employees from 1970 to 2003 (from 32,139 employees in the nine counties in 1970 to 17,045 employees in 2003). ${ }^{72}$ Continuing mechanization is largely responsible for these figures. The amount of surface mined acreage has continually increased since 1982 and surface mining production has been on the increase since $1991 .^{73}$ This is largely attributable to the newest surface mining machinery, such as that used in MTR. ${ }^{74}$ The mechanization that swept through the industry over the course of more than five decades resulted in a vast decrease of needed workforce. The mechanization progress embodied by MTR has quickened that decrease in manpower. Since the introduction of the twenty-story dragline in the 1980s, coal mining employment has plummeted from 59,700 in 1980 to 15,200 in $2004 .^{75}$ Coal production has increased minimally as well, but the bottom line for companies has vastly improved as the highest cost of operating, labor, has been nearly eliminated. Fifty years ago, coal mining employed tens of thousands of mostly

\footnotetext{
${ }^{71}$ Christiadi and George Hammond, "How Well Did We Retain and Attract Highly Educated Workers?" West Virginia Business and Economic Review 9 (October 2003): 1-6.

${ }_{72}$ Numbers derived by adding employment numbers for the nine counties found in Chapter One.

${ }^{73}$ Hammond and Christiadi, "Retain and Attract," 1-6.

${ }^{74}$ West Virginia Coal Association, West Virginia Coal Facts 2001 (Charleston, WV: West Virginia Coal Association, 2001); West Virginia Bureau of Employment Programs, West Virginia Nonfarm Employment by Industry, 1939-1999, available from http://www.wvbep.org/bep/lmi/e\&e/nf_39-99.htm, February 14, 2005.

${ }^{75}$ West Virginia Bureau of Employment Programs, West Virginia Coal Mining Employment 1950-2004, available from http://www.wvbep.org/bep/lmi/e\&e/nf_39-99.htm, February 14, 2005.
} 
underground miners and their labor produced nearly the same amount of coal that is now being produced with a mere fraction of previous numbers.

In spite of it all, many of the people remain. They do so largely because of close personal and historical ties to the land, community, and kinfolks, and often do so at risk to themselves and their property. On the surface, it would seem far easier for the companies to simply buy out these homeowners, securing complete control of the entire area. In many areas where significant MTR has occurred, this tactic has been used. Blair, West Virginia, for instance, has seen a sharp decline in its population. By 1998, fewer than 27 families still remained in the area, down from 180 families just years earlier. ${ }^{76}$ In Blair, both residents and businesses were bought out by Arch Coal with businesses purchased first, resulting in the loss of these business taxes. Residents would soon find themselves traveling miles for basics such as milk and bread, massive buy outs of the residents in the area took place, and population decline forced the closure of school systems, often the death knell for a small community. ${ }^{77}$ Before selling, homeowners signed agreements that they would never again return to the area to live and agreed not to criticize the strip mine operations. From the standpoint of the company it made perfect sense. Then vice president and spokesman for Arch, David Todd provided the companies' philosophy in a court deposition, "Our philosophy is not to impact people and if there are no people to impact, that is consistent with our philosophy." 78 In its quest to limit the adverse affect MTR has on communities, the best solution equaled removal of the communities. In truth, these communities present an obstacle to the corporations which need the land for expansion. Only through the elimination of these communities can this be achieved. Whether this elimination comes from

\footnotetext{
${ }^{76}$ Martha Bryson Hodel, "Residents Praise, Vilify the Coal Industry," Charleston Gazette, September 23, 1998; "Mine Guts Town, Some say; Blair Mountain Residents Upset over Shrinking Population," Charleston Daily Mail, August 18, 1997.

${ }^{77}$ Hodel, "Praise, Vilify."

78 “Buying Blair: Arch Removes Community,” Charleston Gazette, November 27, 1998.
} 
buy-outs or through coercion tactics is of no consequence. Paying someone to leave, or creating nuisances so severe, such as the huge flyrock, dust, and noise encompassed in MTR activities, that it in turn forces people to sell-out does not matter. The end result is the same, depopulation of the coalfields and easy access to the coal. In the case of Arch Coal and its Logan County operations, typically they would not offer to buy residents out, but increasing activity at the mines forced residents to come to Arch asking for a buyout. Residents then signed an agreement to not come back to the communities, to not speak out against the mining activity once leaving the area, and to withdraw previous complaints about the mining. Such wording is illegal, but that fact was unknown to those signing the agreements. These buyout plans affected eleven communities and eleven hollows near Blair Mountain. If not through buyout or coercion, communities may be destroyed by environmental accidents that occur because of MTR. One small Logan County community, Yolyn, was dismantled after summer flooding resulted in the partial collapse of a valley fill into the middle of the road. Residents complained to state agencies and the company then began evicting residents from the company owned property, thus eliminating the community and any source of grievance that accompanied them. ${ }^{79}$

Arch Coal is not the only entity to embrace such policy. Some industry lawyers openly applaud and encourage the removal of people. In 2000, a Charleston, West Virginia, lawyer made multiple presentations on his own to various groups of citizens about that very subject. The attorney is employed by a well-respected, well-established Charleston, West Virginia, law firm which handles employer cases including labor and government and environment and energy litigation, including coal. The lawyer is part of the firm's department that represents corporations in permitting and penalty negotiations as well as appeal hearing and rulemaking

\footnotetext{
${ }^{79}$ Patrick McGinley, "From Pick and Shovel to Mountaintop Removal: Environmental Injustice in the Appalachian Coalfields," Environmental Law Vol. 34, No. 1 (2004), 81.
} 
proceedings. The firm noted its wide-ranging experience identifying and minimizing environmental liabilities for its clients.

The attorney's presentation detailed the presumed problems with MTR in southern West Virginia. Obviously, this attorney believed that eradicating the area of its inhabitants is the ultimate solution. The attorney failed to address the environmental problems that would still remain regardless of population numbers. The hundreds of miles of streams that would be affected, for instance, run into other streams and would, thus, negatively affect those water outlets as well. In the presentation, the effect on wildlife was dismissed. It was asserted that saving the wildlife, particularly any endangered species that might be affected, was not worth the social or economic cost. For emphasis, it is added, "people will always be more important than insignificant species whose only value is spiritual." ${ }^{80}$ The presenter also dismissed residents' claims of home and well damage due to blasting, stating that most such complaints have no merit and the homes already had damage and that both types of claims would decline with pre-blast surveys. The environmental impact was also questioned as well as the idea of any real type of development on these areas. The attorney gave specific arguments in favor of MTR.

Reclamation was lauded as being mostly successful and the use of these areas for hardwood and softwood forests was mentioned and noted that the presenter had witnessed successful regrowth of "hardwood saplings up to three feet tall," but did not mention the scientific proof that such endeavors have rarely been successful. ${ }^{81}$

\footnotetext{
${ }^{80}$ Presentation information in possession of author. During the course of research for this document, author was able to obtain a copy of one of the presentations given in January 2000. Author was asked to maintain confidentiality from where the document was originally obtained. In order to do so, no pronouns have been used so the gender of the presenter is not revealed, nor the presenter's employer.

${ }^{81}$ Ibid.; Not mentioned were the academic studies that concluded just the opposite. Please see Chapter Six for more information on this.
} 
Another argument in favor of MTR was that it removed more coal than traditional mining techniques (the presentation quotes 98 percent compared to 70 percent) and provided employment. The most stark argument, however, was the final argument offered which is that MTR assisted in depopulating the coalfields which, it was asserted, proved the only way to solve the long-term poverty found in the ten counties. Rather than encouraging economic development in the area, the presentation noted the huge financial drain on the miners who, it is asserted, pay the majority of the taxes with $2 / 3$ of the area dependent upon $1 / 3$ that worked as coal miners. The "core problem" as the presenter sees it "is too many people. Way too many people." The attorney then sets out various proposals to handle this problem. One proposal encouraged the state to eradicate dilapidated coalfield homes. Another proposal suggested that the state provide grant money to aid people in settling outside of the state and if the family moved back to the state, to revoke the grant. Yet another idea entailed offering free college education for coalfield kids whose families relocated outside of the region as well as to single adults and childless couples. The main goal would remain getting people to move. A final suggestion allowed for the condemnation, and forced taking, of land if "stubborn people" refused to move and then selling the condemned land to the companies wanting the land for MTR. The company would then reimburse the state for any expenses the state entailed securing the land. The presenter did not believe that such suggestions would ever be embraced by a West Virginia government that the attorney deemed lacking in political guts to depopulate the southern coalfields. The presenter still believed the coalfields would be depopulated, but in a more agonizing way than it has to be and without the assistance that the attorney outlined in the presentation. ${ }^{82}$ It is certain that such depopulation would allow the companies carte blanche control of the coal rich southern counties

\footnotetext{
${ }^{82}$ Ibid.
} 
and that tactics so far employed by many coal operators seemed to embrace the idea of depopulation.

As MTR is currently practiced, three distinct stages of power relations can be discerned among communities affected by MTR. Stage One, is the infancy/beginning stage. In this stage, community members are often trusting of the companies, believing the companies to have the best interest of the community at heart. They welcome the companies for the employment and tax revenues they will generate. Initially, the community sees the company as the savior who will deliver it from its economic plight. Stage Two is the intermediate or middle stage when community member are shocked, dismayed, and angered as the MTR practices begin to directly effect the community in a negative way. Shrinking employment finds many workers laid off. Those with jobs at the sites laud the company and see the jobs as protecting their homes. Others leave in search of work, or to escape the effects of MTR and steady migration from the area begins. As companies begin to offer to buy out households, community members band together in an effort to save their communities. The role of savior begins to crumble, and the company instead finds itself in the dual role of protector of jobs or robber baron of the land. In Stage Three, the final stage, massive buy-outs of homeowners and businesses dovetail, intense depopulation occurs, and migration escalates and soars. The community is essentially gobbled up by coal companies as MTR operations expand and consume the surrounding land while inevitably displacing residents. Once entrenched, this stage cements the company as destroyer and is complete when all members of the community are moved, the community itself dissolved with all associated local businesses and schools closed. As a community moves from one stage to the other, the number of residents plummet, MTR acreage increases, and employment begins to slightly increase, followed by a tapering off of employment as MTR activities expand. The 
need for manpower is replaced with the need for huge draglines. It is expected that more and more southern West Virginia communities will experience these stages as MTR becomes more prolific throughout the area. Throughout the various stages, the power relationship remains the same with the company firmly enjoying the upper hand.

By 1920, West Virginia's bountiful hardwood forests were nearly eradicated. It took eighty years for the forest to replenish itself. Coal, of course, is a finite resource and will not replenish. Four generations have passed since the decimation of the state's hardwood forests and the birth of the railroads that would take West Virginia's bountiful natural resource treasures of coal and timber to places outside the region. The repercussions of constantly extracting with no thought of the future consumed those within the region. There were jobs, but at what cost. At the turn of the nineteenth century, West Virginia's inhabitants learned a difficult lesson about what such a "dance with the devil" could do. In this present struggle once again balancing economics with community needs for a safe and functioning environment, this generation has now done the same.

\section{$\underline{\text { Conclusion }}$}

For generations, southern coalfield communities have been at mercy of the coal industry that provides the only viable economic opportunity while simultaneously destroying the communities themselves. As mechanization such as that encompassed by MTR increased in the region, both employment and population decreased. As larger companies, many of them nonunion, began to dominate the southern coalfields, the make-up of coal communities changed. No longer did supervisors and mine foremen live in the communities where they worked. As MTR became more pervasive in these areas, fewer of these employees lived in the communities where they worked. Thus, the connection with the community itself decreased while the effects the 
mining had on the community increased. Small communities felt the brunt of this transformation.

The reality of living in a single industry economy has burdened these communities and often pitted neighbors against one another. While MTR has well-known repercussions for the environment and those living near the sites, this has not stopped the embracement of the few high paying jobs these operations produce in areas notorious for high unemployment. Those economically benefiting from these jobs are directly pitted against those who believe the cultural and environmental cost of extracting coal by MTR is a much too expensive price to pay. In the past, the region's residents have borne consequences of a non-diverse economy fixated on natural resource extraction. The present generation is once again facing the same dilemma. Whether it decides to face the problem head-on, demanding politicians and those in control provide economic diversification and alternative employment options, or once again rely on a one-resource economy has yet to be seen. Nearing the end of its reign, the coal industry, aided by sympathetic politicians, continues its chokehold on southern West Virginia communities and looks to remain in the same position for the foreseeable future. 


\section{Chapter Four:}

You Scratch Mine, and I'll Scratch Yours:

The Political Economy of Coal in Southern West Virginia

"[W]hether we like it or not, West Virginia's hills will be stripped, the bowels of the earth will be mined and the refuse strewn across our valleys and our mountains in the form of burning slate dumps. This refuse will continue to be dumped into our once clear mountain streams. We are paying a fearful price to allow the coal to be extracted from the hills of West Virginia...." -- Gov. William C. Marland (1953-1957) ${ }^{1}$

From its inception, West Virginia supplied numerous opportunities for the business entrepreneur and its earliest political leaders were its biggest salesmen. An abundance of natural resources attracted businessmen looking for new capitalist ventures, and the largely untapped natural resources offered a variety of ways to make one's fortune. The backcounties of southern West Virginia failed to develop at the same rate as other regions of the state. Politicians saw the coming of the coal industry as an opportunity for unlimited expansion of industry to the areas that heretofore had been too remote to see any real industrial development. When describing his and Governor Aretus B. Fleming's participation in this development, Governor William A. MacCorkle went so far as to state that the two of them served as "advertising agents on a large scale." Since its first exploitation, coal has remained the sole economic driving force for most of southern West Virginia and has continually wielded more political power in the area than it did in other coal regions of Appalachia. ${ }^{2}$

In West Virginia, development of the coal industry equated with progress. The lines between the two primary political parties became undetectable as support for the coal industry

\footnotetext{
${ }^{1}$ William C. Marland, “Governor William C. Marland Proposes The Severance Tax," in West Virginia: Documents in the History of a Rural-Industrial State, ed. Ronald Lewis and John Hennen (Dubuque, IA: Kendall/Hunt Publishing Company, 1991), 304.

${ }^{2}$ Paul Rakes, “Acceptable Casualties: Power, Culture, and History in the West Virginia Coalfields, 19001945” (Ph.D. diss., West Virginia University, 2002), 70, 71.
} 
superseded all other allegiances. In fact, alliances formed around coal interests with the singular purpose of defeating any threats to the established economic system, especially any legislation that endangered the powerful coal industry. Ex-Governor Fleming had first hand knowledge of such ties going so far as to tell a potential gubernatorial candidate that they were not in politics for any particular side, but to defeat anyone fighting against the coal interests. ${ }^{3}$

Coal interests realize the importance of having a politician on their side during key legislative battles and in important government jobs, and are diligent in forming their alliances with politicians. There are key positions at the state level that could, in particular, aid the coal interests -- governor, legislative leaders, tax commissioner and the Department of Natural Resources director. As tax commissioner, the person in this position has the power to set favorable rates on taxes for coal companies. Many have done just that. A 1972 study by the Appalachian Regional Defense Fund (ARDF) found that once leaving these posts, many former tax commissioners found corporate jobs within the coal industry or a coal dependent enterprise. ${ }^{4}$ The same can be said of West Virginia's ex-governors. Since the time of that 1972 study, every governor has been closely aligned with the coal industry, often obtaining employment with a coal company after leaving office, or they continue to support the coal companies in their political careers. These politicians realized that political success hinged upon their backing the coal industry. The economic policies embraced by West Virginia's politicians are inextricably linked to coal and have become a solid part of the region's history. The residents, in turn, are caught in a vise between politics on one side and the coal industry on the other. The large amount of absentee landownership ensured that outside interests would take precedence over the well being of actual residents of the region.

\footnotetext{
3 Ibid., 75.

${ }^{4}$ John Calhoun Wells, Jr., "Poverty Amidst Riches: Why People are Poor in Appalachia" (Ph.D. diss., Rutgers University, 1977), 315.
} 
West Virginia Democrats and Republicans are quite similar in their alliance with coal companies. A large majority of the state's voters are registered Democrats, and Democrats have dominated state government since the New Deal. The majority of West Virginia's governors, for instance, have been affiliated with the coal industry either as owner, manager, or lawyer, a fact that has greatly benefited the industry. In essence, political and business leaders are so closely aligned that differentiation between the two roles is nearly indiscernible. One excellent example of this occurred during Governor Cecil Underwood's second term (1997-2001). Underwood, a former Island Creek Coal Company Executive, relieved several coal companies of more than \$400 million in unpaid Workermans' Compensation premiums and interest by dismissing lawsuits initiated by Underwood's predecessor, Gaston Caperton. ${ }^{5}$ The larger companies contended that they did not owe money to the Workmans' Compensation fund. ${ }^{6}$ However, a 1993 Workmans' Compensation law had made the larger companies responsible for any unpaid premiums incurred by their subcontractors, and the lawsuits alleged that the larger companies had subcontracted with smaller contractors specifically in order to avoid paying the premiums. ${ }^{7}$ Underwood received in excess of $\$ 500,000$ from coal industry donations for both his campaign and the subsequent inaugural ball. It was some of these same coal donor's that benefited from the dismissal of the Workmans' Compensation lawsuits. During Governor Bob Wise's tenure,

\footnotetext{
${ }^{5}$ Paul Nyden, "Panel Votes to Drop Big Coal Firms from Lawsuits: Compromise Benefits State, Kiss says; Critics say Questions Remain," Charleston Gazette, March 13, 1999; Jennifer Bundy, "Court Says Workers Compensation Cases can be Dismissed," Associated Press, July 14, 1999; "Probe? Ugly Allegations," Charleston Gazette, June 14, 2001.

${ }^{6}$ Paul Nyden, "Donors Owe Workers Comp Fund: Coal Operators Heavily Funded Underwood, Who Called off Suits," Charleston Gazette, December 31, 1997.

${ }^{7}$ Brian Bowling, "Wise Considers Renewing Suits: Governor-Elect is Reviewing Status of Workers' Comp Claims," Charleston Daily Mail, November 23, 2000.
} 
however, the lawsuits were re-filed, and fifteen coal companies agreed to pay $\$ 56.6$ million to settle the case, far below the $\$ 400$ million originally owed. ${ }^{8}$

Taxes are the main avenue by which the state recoups monies from natural resource extraction. While politicians, executives, and some inhabitants alike laud the amount of taxes put into the system by the industry, it is arguable that the amount of severance taxes and taxes on the industry itself is still not enough to sustain these communities and correct the damage that occurs at the hands of the very industry that provide for the area's economic life. The industrybiased tax code was forged by West Virginia's earliest leaders who intentionally shaped the tax policy to encourage industry and to shift the tax burden to non-corporate citizens. The state's tax base never kept up with the demands of its growing populace and the citizenry of West Virginia has bore the brunt of taxation. ${ }^{9}$ Out of the fifteen million acres that comprise West Virginia, three million acres are publicly owned. Two-thirds of the remaining twelve million acres are owned by outside interests. ${ }^{10}$ Unimproved land (such as coal rich land which has yet to be mined) is taxed at a much lower rate than improved land. These factors greatly diminish the tax base of the area. ${ }^{11}$

The rate at which any entity living or operating a business in West Virginia is found in the state's tax system which consists of four classifications and is based on "true and actual value" of the property. Each is "subject to a rate limit, amounts per $\$ 100$ of assessed value." Class I includes agricultural property, products of agriculture, and all notes, bonds, bills, leases and accounts receivable; levy limit fifty cents. Class II is owner-occupied residential property,

\footnotetext{
${ }^{8}$ Paul Nyden, "Coal Companies to Pay \$ 56.6 Million in Unpaid Workers' Comp in West Virginia," Charleston Gazette, April 10, 2002.

${ }^{9}$ Lewis, Transforming the Appalachian Countryside, 61, 66-67.

${ }^{10}$ Miller, "Absentees Dominate Land Ownership," in Who Owns West Virginia?, 3.

${ }^{11}$ Barbara Rasmussen, Absentee Landowning \& Exploitation in West Virginia, 1760-1920 (Lexington, KY: University Press of Kentucky, 1994), 141.
} 
including farms, and minerals under the property; levy limit one dollar. Class III property is all real and personal property outside municipalities, other than I and II, including severed and commercially owned minerals; levy limit $\$ 1.50$. Class IV is all real and personal property inside municipalities other than I and II; levy limit two dollars. It was not until 1971 that West Virginia allowed an appraisal of the coal itself. Still, each county appraiser has the authority to assess the property between 50 and 100 percent of the assessed value. ${ }^{12}$ This results in the coal reserves being taxed at different levels from county to county, and all at a very low rate. When that fact is added to the amount of tax revenues lost to the three million acres of publicly owned land, it simply results in a dwindling, debilitated tax base. A 1980 study showed that the average tax per acre on mineral land owned by corporations was between $\$ 1.08$ to $\$ 1.51$ per acre. ${ }^{13}$

Corporations are also able to drive down the amount of taxes owed by leasing land they own to individuals. This drops their tax rate from Class III to Class II and effectively cuts their property taxes for that piece of land in half. ${ }^{14}$

Realizing the loss in tax revenues from the current tax system, the state has recently made attempts to address the problem. As recently as June 1997, Governor Cecil Underwood formed a Commission on Tax Fairness (aka Fair Tax Commission) with the goal of recreating West Virginia's tax system. The bi-partisan commission recommended repealing personal property taxes and replacing the numerous business taxes with a flat 2 percent business tax. A family of four earning $\$ 25,000$ would have saved more than three hundred dollars per year while a coal

\footnotetext{
${ }^{12}$ Appalachian Land Ownership Task Force, Land Ownership Patterns and Their Impacts on Appalachian Communities: A Survey of 80 Counties (Washington, DC: Appalachian Regional Commission, 1981), 70; Appalachian Land Ownership Task Force, Appalachian Land Ownership Study, Volume VII, West Virginia (Washington, DC: Appalachian Regional Commission, 1981), 6-7.

${ }_{13}$ Appalachian Land Ownership Task Force, Appalachian Land Ownership Study, 37.

${ }^{14}$ Miller, Who Owns West Virginia, 18.
} 
company's taxes would have raised by a little more than $\$ 300,000 .{ }^{15}$ The recommendations were met with dissent. The Affiliated Construction Trades Foundation (ACTF) sponsored a study that showed the newly proposed tax structure benefited wealthier West Virginians and increased the tax burden on the middle class. The Commission continued to stand by its original suggestions. ${ }^{16}$ In 1999 and 2000, state legislators failed to act on the recommendations, opting instead to keep the tax system as it was. ${ }^{17}$

In July 2004, the state, through the secretary of tax and revenue, sought to clarify the tax code as it pertained to the extraction of natural resources. For partially mineable and partially mined out property, the tax would remain at five dollars per acre. For mined out land, the property would be taxed at one dollar per acre. Likewise, barren coal acreage would remain taxed at one dollar per acre. ${ }^{18}$ Conversely, average private property owners continue to be assessed based on any improvements they may have made and, again, the amounts vary greatly from county to county, but most assuredly are more than one dollar an acre. The state continued to suffer from a tax system that leaves the heaviest burden on individual taxpayers, rather than the corporations. A September 2004 report by the Massachusetts Taxpayers Foundation showed that West Virginia, the poorest state in the union, had the eighth highest tax burden in the United States in 2002 per personal earnings. ${ }^{19}$ A 2000-2001 study revealed that the majority of West Virginia's taxes came from its citizenry with a full 73 percent of taxes attributed to either

\footnotetext{
${ }^{15}$ Stephen Singer, "Massey May Move to West Virginia; Underwood Names Group to Studay Taxes," Charleston Daily Mail, July 26, 1997; Stephen Singer, "Reform Measure would Change Taxes Little, Data Show," Associated Press, January 14, 1999; Jennifer Bundy, "Tax Fairness Report Late, but 99\% Done," Charleston Gazette, December 29, 1998; "State Plans to Shift Tax Emphasis," Charleston Gazette, August 9, 1998; Stephen Singer, "Panel Urges Revamping of Tax Code," Charleston Daily Mail, February 2, 1998.

${ }^{16}$ Karen Fischer, "Study Says 'Lower End' Carries Tax Burden: Labor-Sponsored Report Contradicts Governor's Panel," Charleston Daily Mail, March 24, 1999; Robin Capehart, "Governor's Commission on Fair Taxation Proposes Business," Charleston Gazette, March 30, 2000.

${ }^{17}$ Jennifer Bundy, "House Leaders Say Tax Plan Will Not Pass As Is," Associated Press, July 13, 1999;

${ }^{18} \mathrm{John}$ C. Musgrave, Valuation of active and reserve coal property for Ad Valorem property tax purposes (Charleston, WV: West Virginia State Tax Department, 2004), 25.

${ }^{19}$ Massachusetts Taxpayers Foundation, Massachusetts' Tax Burden Falls to Bottom Tier of States (Boston, MA: Massachusetts Taxpayers Foundation, 2004.)
} 
personal income taxes ( 38 percent) or consumer sale and use taxes ( 35 percent). Business taxes accounted for 25 percent of the tax base with the remaining 2 percent being described as "other." Still, West Virginia's future will most likely not include any increase in business taxes as the state is continually forced to compete with other state's to attract business. While the business taxes are far less of the tax base than what citizens pay, it is still relatively high compared to most of the states surrounding West Virginia. ${ }^{20}$

One of the most contentious business taxes has been the severance tax. The struggle to enact a severance tax on natural resource extraction remains a good example of the political influence of the coal companies. This much debated and maligned tax on natural resource extraction suffered three distinctive defeats before finally becoming law in the late 1980s. The early 1900s saw the defeat of severance tax initiatives by both Governors Albert B. White and Henry D. Hatfield (1901-1905 and 1913-1917, respectively). Historian John Alexander Williams noted that West Virginia tax reform surrounding natural resource extraction had been debated in "agrarian circles since the 1880s." The failed Tax Commission of 1903 was the most ambitious endeavor up to that point. Corporations fought tirelessly against reforms such as the complete overhaul of fiscal administration, larger corporation license taxes and, in particular, against the notion of a severance tax. In the end, the corporations proved victorious and the ambitious program was thwarted. ${ }^{21}$ Some fifty years after this attempt, Governor William C. Marland (1953-1957) made another failed effort to pass a severance tax on natural resources. Marland was from a coal mining, not coal baron, family, grew up and lived in a mining town in Wyoming County, and had worked in and around coal mines. He was motivated by the desire to

\footnotetext{
${ }^{20}$ Mehmet S. Tosun, “A Comparative Assessment of West Virginia’s State Tax System,” The West Virginia Public Affairs Reporter 19, no. 3 (Summer 2002), 2-7.

${ }^{21}$ John Alexander Williams, West Virginia: A History (Morgantown, WV: West Virginia University Press, 2001), 153-154.
} 
see that the companies gave back to the communities that were sacrificing so much for the coal to be extracted from their mountains. As usual, the cry of "ruination of the industry" arose from the coal industry. Marland's attempts at tax reform were quickly thwarted, and he was soundly defeated by a state legislature firmly wedded to the coal interests. ${ }^{22}$ He subsequently lost his second gubernatorial bid in 1956 to a young up and coming businessman, Cecil Underwood. Marland's political and professional careers were ruined. He opened a law practice and industrial consulting business after leaving office, but could not secure the lucrative coal industry business because of his prior support of a severance tax. ${ }^{23}$ After two failed attempts to become a West Virginia Senator, Marland moved to Chicago where he worked as a sales director for West Kentucky Coal Corporation for less than a year before the alcoholism that had continually plagued him consumed him. In the summer of 1961 he was fired from his job with the coal company, received treatment for alcoholism, and by 1962 was employed as a taxicab driver in Chicago. His plans to return to his native West Virginia to work for a political friend were tragically halted when he was diagnosed with pancreatic cancer and died at the age of $47 .^{24}$ While two of his successors, W.W. "Wally" Barron (jury tampering) and Arch Moore (extortion, mail and tax fraud, and obstruction of justice), served time in jail for their crimes, none of his successors attempted to stand up to the coal companies in such a way as Marland and, arguably, none have met a fate so harsh as his. While plagued with personal tragedies of his own, Marland at least tried to gain some degree of state compensation for extracted natural resources.

\footnotetext{
${ }^{22}$ Paul Lutz, From Governor to Cabby: the Political Career and Tragic Death of West Virginia's William Casey Marland, 1950-1965 (Huntington, WV: the Marshall University Library Associates, 1996), 41-61.

${ }^{23}$ Lutz, 220

${ }^{24}$ Lutz, xi, 220-242.
} 
For this, he was effectively destroyed as a politician and as a person. His coal severance tax would not be realized until $1987 .^{25}$

Before the severance tax could become law, the state had to experience a surge in reform movements spanning the 1960s and through the 1970s. The 1960s saw the formation of the Human Rights Commission, the West Virginia Industrial Development Authority, and the Department of Commerce among others. ${ }^{26}$ The Association of Disabled Miners and Widows and the Black Lung Association fought for the rights of disabled miners and widows in obtaining compensation for black lung. Under Arch Moore, Jr.'s, first administration (1969-1973), pressure from these groups along with a 1969 wildcat strike of UMWA miners in support of making black lung a compensable disease assisted in the passage of both state and federal regulations recognizing black lung as an occupational disease. ${ }^{27}$

Arch Moore, Jr.'s, first two administrations (1969-1977) also witnessed other far reaching reforms, such as programs for the aging, dam control regulations after the Buffalo Creek Disaster, and the sunshine law to allow open public meetings. ${ }^{28}$ As he entered his third and final term as governor (1985-1989), Arch Moore, Jr., inherited the worst economic conditions since the Great Depression. While the severance tax was enacted on his watch, it was also during his administration that super tax credits provided massive tax breaks for existing industry, largely benefiting the coal industry which enjoyed 90 percent of the total "super tax

\footnotetext{
${ }^{25}$ Jean Harris, "Severance, telecommunications, business franchise taxes examined," Charleston Gazette, September 30, 1985. Enacted in 1985, the severance tax became effective July 1, 1987.

${ }^{26}$ Otis Rice and Stephen Brown, West Virginia: A History (Lexington, KY: University Press of Kentucky, 1993), 282.

${ }^{27}$ Bennett Judkins, “The People's Respirator: Coalition Building and the Black Lung Association,” in Fighting Back in Appalachia: Traditions of Resistance and Change (Philadelphia: Temple University Press, 1993), 225-241; Barbara Ellen Smith, Digging Our Own Graves: Coal Miners and the Struggle over Black Lung Disease (Philadelphia, PA: Temple University Press, 1987), 83-85; Rice and Brown, West Virginia: A History, 284.

${ }^{28}$ Rice and Brown, West Virginia: A History, 284-285
} 
breaks." ${ }^{29}$ These super tax breaks were part of Moore's efforts to rejuvenate the quickly plummeting coal industry. Efforts were made to cut coal production costs and a 30 percent reduction in Workmen's Compensation Fund contribution was also provided to the coal industry. In spite of all these efforts, coal employment continued to plunge and a 1990 super tax credit study showed that the coal industry had lost 1,300 jobs even though the industry witnessed a 13.3 percent increase in overall coal production. The tax credits had been used by some coal companies to avoid paying the newly enacted severance tax, costing the state millions of dollars in state revenue. ${ }^{30}$ In 1985 , supercredits cost the state $\$ .6$ million. By 1989, that amount had surged to $\$ 48.2$ million. Abuse was so prevalent and apparent that by 1990 legislation was enacted to stop further such exploitation. The 1990 efforts produced a minimum severance tax to be paid and this overhaul along with 1993 reforms resulted in a decrease in the amount of lost severance tax state revenue to the super tax breaks from $\$ 48.2$ million in 1989 to $\$ 30$ million in 2000. The super credit cost on all other taxes was an additional $\$ 12$ million. ${ }^{31}$ Even while these tax breaks proved beneficial to the coal industry, coal employment continued to decline nevertheless.

The economic benefits of coal, particularly coal obtained via MTR, remains a contentious issue, the roots of which stem from West Virginia's historical marriage of industry and politics. People in business need politicians and, in turn, politicians need the businessmen to fund their political careers. While working under the guise of what is best for the state and its residents, it is not uncommon for politicians to protect the interests of their wealthy business benefactors even as the economic impact of the industry diminishes. A 2001 study conducted by

\footnotetext{
${ }^{29}$ Ibid., 287-289.

${ }^{30}$ Ibid., 288-289

${ }^{31}$ West Virginia Department of Tax and Revenue and West Virginia Development Office, Analysis and Recommendations for West Virginia Tax Incentives (Charleston, WV: Dept. of Tax and Revenue, 2002), 10-12.
} 
the University of Kentucky's Center for Business and Economic Research and sponsored by the Appalachian Regional Commission, found that the impact of the coal industry on Appalachian communities was expected to drop within the decade, "particularly with respect to employment and earnings" which is expected to decline by 25 to 30 percent. Even the impact of collected taxes such as severance, payroll, income and retail taxes is expected to drop by 20.4 percent in the Central Appalachian region which includes the southern West Virginia counties. ${ }^{32}$ From 1980 to 1999 , the national coal industry saw a decrease of 108,000 employees (from 192,000 to 84,000 employees) even while production increased to more than 1 billion tons per year. ${ }^{33}$ The largest surface mines in Appalachia are located in West Virginia, and in both 2001 and 2002 nine out of the top ten largest producing surface mines in Appalachia were found in the southern West Virginia coalfields. ${ }^{34}$ While the overall employment has declined, employment by independent contractors has increased and has actually "more than tripled" from 1980 to $1999 .{ }^{35}$

The high level of employment by independent contractors works favorably for the larger companies because it carries less responsibility for adhering to federal environmental and safety laws as well as not having to pay workman's compensation deductibles for these employees. The company does, however, still reap the financial benefits of the production of these employees in their bottom line. Production per employee has also increased with the average

\footnotetext{
${ }^{32}$ Center for Business and Economic Research Gatton College of Business and Economics, A Study on the Current Economic Impacts of the Appalachian Coal Industry and its Future in the Region: Final Report (Louisville, KY: University of Kentucky, March 27, 2001), 3.

${ }^{33}$ George Bockosh, Barbara Fotta, and William McKewan, "Employment, Production, and Fatality Trends in the U.S. Coal Mining Industry," Coal Age, October 28, 2002, available from http://coalage.com/ar/coal_employment_production_fatality/index.htm.

34 Steve Fiscor, "Top Ten Mines of Appalachia," Coal Age, March 1, 2002, available from http://coalage.com/ar/coal_top_ten_mines/index.htm; Bill Meister, "Top Ten Mines of Appalachia," Coal Age, March 1, 2001, available from http://coalage.com/ar/coal_top_ten_mines_2/index.htm.

${ }^{35}$ Bockosh, etal., "Fatality Trends," Coal Age; Meister, “Top Ten Mines," Coal Age.
} 
surface mine employee producing 18,436 tons per year in 1999 compared with the 8,488 tons per year per underground coal miner in $1999 .^{36}$

These statistics clearly show why surface mining is such a desirable alternative for many coal companies when each employee can produce more than twice the amount of coal as their underground counterparts. This, combined with the recent upswing in demand for the lowsulfur, high volatility coal that the southern West Virginia coalfields are so noted for, has meant an increase in sales revenues. In May 2004, a Charleston Gazette article noted Massey Energy's upbeat outlook, and reported that the company estimated that sales on the global market could reach eighty to ninety dollars per ton. ${ }^{37}$ With the high demand and increased prices for low sulfur coal, the mining industry in 2003 extracted 1.7 billion tons of coal. The industry was on track to exceed its 2004 goal of 1.1 billion tons. ${ }^{38}$

While the coal industry's bottom line has been improving, West Virginia's economy has been on the decline for decades, and the loss of mining jobs has hit the southern West Virginia region particularly hard. Since 1970, the nine counties have witnessed a loss of 21,968 jobs (or 66 percent of total mining jobs) from 33,263 mining jobs in 1970 to 11,295 coal mining jobs in 2003. At the same time, total production has increased from more than 27.1 million surface mined tons from all surface mining techniques throughout West Virginia in 1970 to more than 38.7 million tons mined in the nine counties by the MTR method alone in 2002. This is a marked increase in surface production and shows that MTR is leading the way in that increase. As the coal industry mechanized and as surface mining became more prolific, fewer and fewer people were able to make their living in the coal industry. As MTR expanded in the 1990s and a

\footnotetext{
${ }^{36}$ Ibid.

${ }^{37}$ Edward Peeks, “Coal Industry Sees Better Times Ahead," Charleston Gazette, May 11, 2004.

${ }^{38}$ United States Department of Energy, Energy Information Administration, Monthly Mined Coal Statistics, 2003, 2004, available from http://tonto.eia.doe/gov/FTPROOT/coal/weekly/monthprod2003tot.xls and http://tonto.eia.doe.gov/FTPROOT/coal/weekly/monthprod2004tot.xls.
} 
few large corporations monopolized the industry, the number of small companies rapidly declined. This growing domination allowed the larger companies to become more competitive with the burgeoning western coal industry, particularly Wyoming's Powder River Basin. Massive companies such as Arch Coal and Massey with large MTR mining sites have pushed other companies to the side in overall production measures. ${ }^{39}$ Along with the increased production and increased surface mining, including MTR, has come a decrease in overall mining jobs. Mechanization has displaced tens of thousands of workers in the past and continues to displace them in the present as today's mammoth machines do the job of hundreds of workers. The subsequent decrease in employment has also led to an increase in social welfare assistance for those who remain in the areas.

The poor state of the region's economy has resulted in an increase in welfare and food stamp recipients. ${ }^{40}$ Statistics from the Department of Health and Human Resources show that the number of families receiving food stamps steadily increased from 89,446 in August 2001 to 101,561 in August $2003^{41}$ at a time when the population for the state has consistently declined and when eligibility requirements have been tightened. A 2003 article in the Charleston Daily Mail quoted Secretary for the Department of Health and Human Resources Paul Nusbaum as saying that he believes there is "a direct relationship between poor economic conditions and increasing benefits" paid out to recipients. He also noted that while the number of eligible recipients swell, the state does not have the tax revenues to pay for it. ${ }^{42}$ The nine southern West Virginia counties shared in this burden. In 1998, transfer payments accounted for more than 20 percent of each county's total personal income except Kanawha County where it accounted for

\footnotetext{
${ }^{39}$ Ken Ward, Jr., "Coal Industry Competition made Mines Bigger," Charleston Gazette, June 6, 1999.

${ }^{40}$ Josh Hafenbrack, "State Welfare Rolls Rise: Officials Cite Poor Economy Efforts to Assist Families," Charleston Daily Mail, September 25, 2003.

${ }^{41}$ Ibid.

${ }^{42}$ Ibid.
} 
19.8 percent. ${ }^{43}$ The amount of total personal income of each county coming from transfer payments such as Social Security Disability, Supplemental Security Income, Temporary Assistance for Needy Families (TANF), retirement benefits, and unemployment saw an increase in the total of personal income from 1988 to 1998 . The other eight counties saw Boone County at 25.5 percent, Fayette at 34.1 percent, Logan at 34.5 percent, McDowell at 46.2 percent, Mingo at 32.1 percent, Nicholas at 29.7 percent, Raleigh at 26.6 percent, and Wyoming County at 34.9 percent. ${ }^{44}$ Basically, this means that there are larger and larger numbers of people in each county receiving public assistance of some sort, and fewer and fewer employed individuals contributing to the tax base of each county. McDowell County, for instance, showed nearly 50 percent of its population dependent upon some means other than employment for their survival, and the other 50 percent provided more of the county's tax base. The end result is a lack of services for the county overall. The per capita payments for three income maintenance programs, Temporary Assistance for Needy Families (TANF), Supplemental Security Income (SSI), and Food Stamps, is twice as high in Central Appalachia as in Northern and Southern Appalachia. ${ }^{45}$

By the end of the decade, in 2010, an increase is forecasted in all of the maintenance programs for Central Appalachia. A 5.77 percent increase in per capita TANF payments, 4.8 percent in SSI payments, and 11.35 percent in Food Stamp payments is expected along with a noted decrease of population. In terms of real dollars, that correlates to a $\$ 6.2$ million annual increase in TANF payments, a $\$ 17.7$ million increase in SSI payments, and a $\$ 24.3$ million

\footnotetext{
${ }^{43}$ Prepared by Chris Condon, Randy Childs, and Leah Bogdan, County Data Profile: Kanawha County (Morgantown, WV: Bureau of Business and Economics, West Virginia University, 2000), 15.

${ }^{44}$ Prepared by Chris Condon, Randy Childs, and Leah Bogdan. County Data Profile: Boone County; County Data Profile: Fayette County; County Data Profile: Logan County; County Data Profile: McDowell County Data Profile; County Data Profile: Mingo County Data Profile; County Data Profile: Nicholas County Data Profile; County Data Profile: Raleigh County Data Profile; County Data Profile: Wyoming County Data Profile (Morgantown, WV: Bureau of Business and Economics, West Virginia University, 2000), 15 of each profile.

${ }^{45}$ Center for Business and Economic Research, A Study on the Current Economic Impacts of the Appalachian Coal Industry and its Future in the Region: Final Report (Louisville, KY: Gatton College of Business and Economics, University of Kentucky, 2001), 87
} 
increase in Food Stamp payments. ${ }^{46}$ For an already economically depressed area, such increases indicate fewer individuals paying into the tax system which could prove devastating to an already depleted tax base. This dwindling tax base and the minimal number of jobs in these areas ensure that the power structure remains the same and that the residents will stay beholden to the coal industry.

Whether receiving transfer payments or not, citizens of the southern coalfields depend on federal and state regulators to oversee and protect them and their environment. Politicians often have more sympathy for and alliance with corporations than inhabitants, going so far as to encourage the delay of studies aimed at considering the concerns of residents. In 1999, the U.S. Department of Environmental Protection, the U.S. Office of Surface Mining, the Fish and Wildlife Service and the Army Corps of Engineers agreed to partly settle a lawsuit brought against them regarding the legality of valley fills. ${ }^{47}$ The agreement stated that an environmental impact study (EIS) would be conducted to examine the environmental, social and economic impacts of MTR, especially addressing the environmental impact of valley fills on the communities. The EIS was supposed to be finished by 2000 . The 2000 deadline came and went and no draft appeared. Politicians and bureaucrats were, once again, dragging their feet. Before President Clinton left office, his administration attempted to release an earlier draft of the EIS but met with complaints from West Virginia officials, namely Gov. Bob Wise, Senate President Earl Ray Tomblin (Logan County), and House Speaker Bob Kiss (Raleigh County). ${ }^{48}$ The Charleston Gazette was able to receive an early January 2001 draft of the EIS in May 2002 through a Freedom of Information Act request. At that time, the report was two and one-half

\footnotetext{
${ }^{46}$ Ibid., 140-141.

${ }^{47}$ For further discussion of Bragg v. Robertson, please see Chapter Five.

${ }^{48}$ Ken Ward, Jr., "Mountaintop Removal could Devastate Region: Federal Study Paints Ugly Picture for much of State," Charleston Gazette, May 5, 2002.
} 
years overdue. Still, it would not be until one and one-half years later, in January 2004, that a more complete draft environmental impact study (DEIS) would be officially released.

The DEIS was met with fervent responses from both sides. In comments written to the DEP regarding the DEIS on surface mining valley fill impacts, coal interests, including the West Virginia Coal Association, responded collectively in a single 138 page response. They pointed out how valley fills are used by both underground and surface mines and stressed that they wanted extra emphasis added to that fact. They stated that the DEIS failed to "acknowledge [the] interrelationship of surface mining to underground mining," and that many of these "underground mines exist solely to provide blending stock for coal produced through surface mining methods as part of a large mining complex." To drive their point home, they declared that surface mined coal is "generally of a better quality" than that obtained via underground methods and that this underground coal would "not produce a marketable product unless blended with a surface mined product. $" 49$

Taken at face value, this statement is hard to believe especially considering that southern West Virginia coal is highly marketable, low-sulfur, high volatility coal - whether mined by surface or underground methods. The marketplace does not support their assertion either; statistics from 1996-2000 show that surface mined coal, on average, brings less per ton than its underground equivalent. See Figure $4.1 .^{50}$ The price difference is larger between the 2002 and 2003 figures for southern West Virginia coal prices by method. In 2002, the cost per ton of underground coal was $\$ 30.20$ and it increased slightly to $\$ 30.72$ by 2003 . In contrast, surface

\footnotetext{
${ }^{49}$ Coal Operators and Associates, the Kentucky Coal Association, the National Mining Association , the Ohio Coal Association, and the West Virginia Coal Association to John Forren, US EPA, January 6, 2004, letter, Joint Coal Industry Comments on the Mountaintop Mining/Valley Fill Draft Environmental Impact Statement (Charleston, WV: West Virginia Coal Association), 118, available from http://www.wvcoal.com/resources/pdfs/FinalEIS.pdf.

${ }^{50}$ United States Department of Energy, Energy Information Administration, West Virginia coal statistics, 1991, 1996-2000, available from http:/www.eia.doe.gov/cnAeaf/coal/cia/a15p01.txt.
} 
mined coal brought $\$ 28.77$ per ton in 2002 and $\$ 29.25$ per ton in $2003 .^{51}$ While the difference in price is not large, they obviously do not support the coal interests' previous assertion at all.

Quite the opposite, it illustrates that underground mined coal is sold at a higher price than that mined by surface methods. What MTR lacks in pricing, however, it makes up for in sheer volume as the companies are able to mine far more coal using the MTR method than underground methods. This, in turn, drives down the cost of production per unit which results in larger profit margins than more expensive underground mining.

\section{Figure 4.1}

Price per ton of West Virginia coal by method

\begin{tabular}{|l|l|l|l|l|l|}
\hline & 1996 & 1997 & 1998 & 1999 & 2000 \\
\hline Underground & 27.31 & 27.64 & 28.25 & 26.21 & 25.79 \\
\hline Surface & 25.04 & 24.60 & 24.50 & 22.39 & 24.67 \\
\hline
\end{tabular}

Source: See footnote 50.

Within the DEIS, the framers remarked that there are other methods to obtain this coal rather than MTR. The coal interests united front begged to differ on that matter. They asserted that most seams currently being strip mined and using valley fills "cannot be recovered using underground mining. The seams are either physically too thin, the overburden too unconsolidated to allow for safe mining or the reserve so isolated or small that underground extraction is either impossible or hopelessly uneconomic." ${ }^{, 52}$

One concern raised by industry in their response is the lack of emphasis on the use of valley fills by underground mines as well as surface mines which could not exist without these massive constructions. Industry is correct to note that underground mining also uses valley fills.

\footnotetext{
${ }^{51}$ United States Department of Energy, Energy Information Administration, Average Open Market Sales Price of Coal by State and Mine Type, 2003, 2002, available from http://www.eia.doe.gov/cneaf/coal/page/acr/table28.html.

${ }^{52}$ Coal Operators and Associates, letter, 124.
} 
What is left unsaid is the small number of valley fills that underground mining actually uses compared with what is used by MTR. The DEIS noted that of the 6,697 valley fills they observed for the study, only 11 percent (or 719) were associated with underground mines. Surface mines accounted for 85 percent (or 5,688) of the valley fills. The remaining 4 percent (290) existed on other sites such as preparation plants, tipples and load-outs. ${ }^{53}$ For the coal industry to encourage the final DEIS to include underground mining in its definition of mountaintop mining by noting the 719 valley fills (or 11 percent) ${ }^{54}$ associated with underground mining is blatantly deceptive and an obvious attempt to manipulate the final report to encourage the "sky is falling" mentality that has worked so well for the coal industry in the past. In their collective response to the DEIS, the coal representatives stated, "As this statistic reflects, underground mines in this steep sloped area also require the construction of valley fills." ${ }^{.55}$ This statistic actually shows that surface mines, and in particular the excessive overburden created by MTR, are largely responsible for the proliferation of valley fills.

Furthermore, a Kentucky mining engineer reviewing the decision of Judge Charles Haden, II, in Kentuckians for the Commonwealth v. Rivenburgh (May 8, 2002) stated that the decision would not affect underground mines. In that case, Haden effectively blocked the Army Corps of Engineers from issuing most valley fill permits unless the companies included a post mining land development plan. He asserted that underground mining fill permits would not, either in the short or long term, be negatively affected, and that underground and surface mines had "little potential" for immediate closings and decreased production. ${ }^{56}$ While eventually appealed and overturned, the decision would not have been the death knell the coal companies

${ }^{53}$ DEIS, Chapter 3, Affected Environment and Consequences, III.K-15, 191.

${ }^{54}$ Coal Operators and Associates, letter, 116.

${ }_{55}^{55}$ Ibid., 116.

56 "Engineer: No Harm in Haden's Ruling - Valley Fills Prohibited," Coal Age, July 1, 2002, available from http://coalage.com/ar/coal_engineer_no_harm/index.htm. 
painted it to be. However, MTR is the one arm of the coal industry that is solely dependent upon valley fills. If the process were not so extensive, and more time were taken, valley fills as currently executed would not be necessary by any other criterion than expediency. Companies could reclaim as they go rather than tearing it all up to get a huge dragline in and hurriedly dumping excess spoil and overburden into the valleys and streams below. Mining the top of a mountain in this manner certainly results in larger valley fills and diminishes the possibility of safer and more effective methods of saving the rock, soil and overburden in a separate area to use in later reclamation.

Another controversial issue, coal haul tonnage, was also hotly debated. In response to coal haulers' requests to increase the limit and coalfield residents' demands to enforce the law, competing legislation attempted to end the debate. After much debate and public input, the 2003 West Virginia legislature passed a highly controversial bill to nearly double the 65,000 tons coal truck weight limit previously allowed to 120,000 tons. The law only applied to fifteen southern West Virginia coal producing counties. All other areas of the state would still have to operate within the previous limits. ${ }^{57}$ Testifying before the West Virginia Joint Commission on Economic Development concerning raising the truck hauling rates, Don Blankenship, CEO of A.T. Massey Energy, stunned spectators by dismissing the death of West Virginians in coal truck accidents as "no more than might be expected given the many miles that coal trucks travel each year." 58 The death of coal miners has typically been viewed as an acceptable means to a justifiable end, and it is no secret that legislative reforms have been at the price of miner's safety. Statements such as

\footnotetext{
57 “Coal Truck Weight Fight Heading North,” Charleston Gazette-Mail, September 21, 2003.

58 "Coal's Victims: Just the Cost of Doing Business?," Huntington (West Virginia) Herald-Dispatch, July 19, 2003.
} 
those made by Blankenship give the impression that now deaths of coal county citizens are also acceptable casualties and "part of the cost of doing business."

The prospect of upgrading the roads to make them more accessible to the heavy coal trucks seems unlikely with a hefty price tag to go with it. Only about 600 miles of nearly 7,500 miles of southern West Virginia roads were intended to hold more than 65,000 pounds. Most of the bridges that these oversized coal trucks will travel are not equipped to handle more than 80,000 pounds, and only 150 miles of roads within the fifteen counties meet these standards. West Virginia Transportation Secretary Fred VanKirk noted that repeatedly exceeding this load could cause "fatigue" and "wear the bridge out." ${ }^{60}$ The Department of Highways, using a 1980 study, estimated that it would cost $\$ 2.8$ billion to upgrade the 3,600 miles of coal haulage roads that the 1980 study had identified as needing such updates. That amount is more like $\$ 6.5$ billion in today's marketplace. ${ }^{61}$ It should also be noted that while passing the law to allow more tonnage in fifteen southern West Virginia counties, the legislature failed to provide any new funding for "upgrading highways and bridges in the Coal Resource Transportation System" as the targeted area has been dubbed. The law does, however, increase the amount charged for permits to haul the larger loads and is expected to generate "between $\$ 200,000$ and $\$ 1$ million in fees" each year, ${ }^{62}$ falling well below the billions needed for updating the roads and bridges. Considering most of these roads were never intended to have constant traffic of excessive weight on it, these fees will certainly do little to upkeep the damage that the heavier trucks can not help but make, nor is it remotely adequate to begin upgrading the roads to handle the heavier loads at all. In essence, if these upgrades are to be made, it is the tax paying citizen, not coal companies,

\footnotetext{
${ }^{59}$ Ibid.

60 "Coal Truck Bill Leaves DOH with Tough Road to Hoe," Morgantown Dominion Post, March 17, 2003.

${ }^{61}$ Dan Radmacher, "Coal Truck Bill is an Economic Disaster for West Virginia," Charleston Gazette, February 28, 2003.

62 "Coal Truck Weight Fight Heading North," Charleston Gazette-Mail, September 21, 2003.
} 
that will, in the end, foot the bill. The economic impact of this bill has yet to be seen, but it surely will be a negative one for the citizens of the coalfields.

While coal unarguably brings in millions of dollars to these southern coalfield counties, surface mining also contributes to millions of dollars worth of destruction due to the ever more frequent flooding, exacerbated by the lack of groundcover that accompanies massive timbering and MTR. A June 2002 Flood Advisory study concluded that MTR does contribute to flooding in the southern West Virginia coalfields by increasing runoff in the study watersheds. ${ }^{63}$

After the 2001 floods, Governor Bob Wise commissioned studies from two consulting groups to ascertain some viable solutions for these flood ravaged areas. The results were not well publicized. The Kentucky firm hired, Parsons Brinckerhoff, concluded that of the communities in McDowell and Wyoming Counties (the focus of the study), only two communities, Mullens in Wyoming County and Welch in McDowell County, were sustainable. The other communities were not sustainable without "significant investment." The main task of the consulting firm was "to work with citizens and community leaders in McDowell and Wyoming counties to develop long-term redevelopment plans." ${ }^{\text {64 }}$ The consulting groups as a whole believed that the strip-mined area was ripe for development as well as new communities, thus moving people from their original home. Remarkably, they suggested using the flat land developed by MTR, the very source of the flooding problems. An employee with the Wyoming County Economic Development Authority admitted that convincing people to move from their longstanding communities would be a difficult task. It was suggested by the consultants that residents be given "the opportunity to move out of old, flood-prone communities but keep them

\footnotetext{
${ }^{63}$ Flood Advisory Technical Task Force, Runoff Analyses of Seng, Scrabble, and Sycamore Creeks, part one (Charleston, WV: Division of Environmental Protection, 2002), 2, 75.

${ }^{64}$ Jim Wallace, "Officials Seek Renewal Funding: State Hopes Firm Can Find Money For Demolitions," Charleston Daily Mail, July 5, 2002.
} 
within the area by building new housing and industrial developments at higher elevations along two proposed highways, the King Coal Highway and the Coalfields Expressway." Pineville and Oceana in Wyoming County also were regarded as sustainable with some restructuring. The other nine municipalities in the two counties were deemed unsustainable. Developing new communities on the newly stripped land near the new highways was deemed most viable. They also suggested that town governments and utility services of small, incorporated towns in the two counties may have to be combined to ensure sustainability. The group suggested new development along the shared boundaries of the two counties. One of the consulting firms, Tischler and Associates noted positive characteristics of the areas as well such as low cost of living, recreational opportunities, low utility costs and rail transportation, but these were offset by such negative factors as low levels of education, stagnant income, limited access by roads and little developable land. ${ }^{65}$ In essence, their solution was depopulation and consolidation. In the case of McDowell County, all other communities besides Welch were considered "physically worn out." Totally sweeping aside concerns about strip mining, and in particular MTR, might have on flooding, State Senator Billy Wayne Bailey (D-Dist. 9) told the Mullens City Council and the Wyoming County Economic Development Authority to look at the recent flooding as though ""God has wiped the state clean" and given them the opportunity to build better communities elsewhere. The Wise Administration wanted to make sure that residents in these areas realized that moving was an option and that no one would be forced to move. The consultants' idea was to "guide and lead" rather than to "push and shove.",66

\footnotetext{
${ }^{65}$ Martha Bryson Hodel, "Flood Recovery Looking at Long-Term Solutions," Associated Press, August 27, 2002; Jim Wallace, "Plan Would Redraw Lines of Towns in Flood Areas," Charleston Daily Mail, August $28,2002$.

${ }^{66} \mathrm{Jim}$ Wallace, "Mayors Oppose Moving to New Developments Mountaintop Spots Aren't the Answer, Two Officials Say," Charleston Gazette, August 30, 2002.
} 
Floods such as those that occurred in 2001, which devastated most of Wyoming County and part of McDowell County, repeatedly cost millions of dollars worth of financial destruction to these economically-strapped communities and inhabitants. A March 2004 editorial in the Raleigh Register-Herald of Beckley, West Virginia, underscored that "[t]axpayers have borne the cost - to the tune of hundreds of millions of dollars - of putting communities back in order after flood waters pour through them. ${ }^{, 67}$ It is not the coal companies that foot the bill for these disasters. It is the West Virginia - and through federal assistance programs such as Federal Emergency Management Agency (FEMA), the national - taxpayer that pays in the long run. While MTR companies hail the number of good paying jobs they bring to the region, as previously noted, the actual number of jobs associated with MTR mining are limited. The cost associated with rebuilding homes and property after flooding must also be considered. The presumed benefits from MTR will never be realized if residents are constantly doling out money because of the damage costs this type of mining inflicts. Southern West Virginia has always suffered floodings, but not at the present rate of frequency and strength. In November 2003, for example, Wyoming County, suffered more than two million dollars in flood damages. FEMA assisted many of the residents, ${ }^{68}$ but others have been told that this was the last assistance FEMA would provide if they continued to reside where they presently live. ${ }^{69}$ Many of these homeowners have, therefore, sold their homes and moved away. Since the federal government now owns the land, less revenues are generated for local governments.

Banning MTR altogether would, indeed, cut overall coal production in the state. A 1999 Charleston Gazette article headlined that banning MTR would cut the state's total coal

\footnotetext{
67 "Flooding: Taxpayers Should Decide on Bonds," Raleigh Register-Herald, March 4, 2004.

${ }^{68}$ Mary Catherine Brooks, "Three Inches of Rain Cause Millions in Destruction," Raleigh Register-Herald, January 5, 2004.

${ }^{69}$ This is personal knowledge of the author from conversations with numerous personal acquaintances, family members and friends affected by these floodings.
} 
production by 10 percent. ${ }^{70}$ The Gazette drew this figure from an industry-sponsored study which also claimed that the coal industry stood to lose about $\$ 490$ million in revenues each year, based on an estimated sale price of $\$ 28$ per ton of coal, and declared that both state and local governments stood to lose thirty-seven million dollars in yearly tax revenues. ${ }^{71}$ While these figures, admittedly, show some impact to the coal industry, they are hardly the death knell that many industry executives claim should there be a decrease or end to MTR.

Some coal company executives would have inhabitants believe that they continue to mine coal in southern West Virginia for largely altruistic reasons, and site statistics that the companies are not making much money from the coal business. In an April 1999 column, the general manager of Arch Coal, Inc., made such an inference. He pointed out that \$18 million of Arch’s \$30 million profits for 1998 came from "land and property sales." He detailed how the other $\$ 12$ million, while made from extracting coal, only equaled $\$ .15$ cents on each of the 80 million tons of coal that it mined. ${ }^{72}$ He went on to describe the massive amount Arch paid out in wages (nearly $\$ 100$ million), to other support industries (more than $\$ 130$ million), and in state taxes (more than $\$ 31$ million). ${ }^{73}$ If this executive's arguments are to be believed, then it would seem that the destruction of thousands of acres of some of the most diverse forest system in the world, the covering of thousands of miles of Appalachian streams, and leaving entire areas uninhabitable is an awfully steep price for the people of West Virginia to pay when even the coal companies are "barely" turning a profit through the environmental and social destruction of southern West Virginia communities.

${ }^{70}$ Ken Ward, Jr., "Mountaintop Mining Ban Would Cut Coal Production 10 Percent," Charleston Gazette, July 23, 1999.

${ }^{71}$ Ibid.

${ }_{72}^{72}$ Robert Bays, “Mountaintop Removal Foes Have Broader Agenda," Charleston Gazette, April 12, 1999.

${ }^{73}$ Ibid. 
It has been so ingrained in the people that the removal of mountaintops attracts businesses that one individual in Marmet, Kanawha County, wanted to use mountaintop removal to clear his 1,000 acres in hopes of luring a Wal-Mart distribution center to his property. The local economy was deteriorating, and the man had hoped that the huge retailer would bring in jobs. Wal-Mart said that the company had no plans to build a distribution center near Charleston, West Virginia. ${ }^{74}$ Similarly, a Williamson, Mingo County, mayor planned to apply for a federal grant to allow the mountaintop removal of one of Williamson's mountains. The mayor hoped that the newly flattened land would be used for an industrial park, a recreational area, shops, and restaurants. ${ }^{75}$ The mayor must not be aware that of the thousands of acres left flattened by MTR, most are not used in the ways he proposed. After three decades, the first MTR site in Fayette County is still waiting to benefit from its MTR experience. No industry, or any type of construction, presently exists there.

While businesses have not been attracted by flattened mountaintops, tourists continue to flock to West Virginia to enjoy its natural beauty. The draft environmental impact statement (DEIS) acknowledged the importance of tourism to West Virginia's economy. In fact, a study by the West Virginia University Bureau of Business Research showed an economic impact of \$2.54 billion in 1991. The DEIS listed hunting, fishing, whitewater rafting, hiking, camping, skiing, golfing, visiting national and state parks as well as fairs and festivals as some of the activities that visitors to West Virginia participated in and emphasized that it is important to keep areas environmentally healthy if they are to continue to attract tourists. ${ }^{76}$ The study noted that tourism in the southern coalfield region is below the West Virginia average and goes on to say

\footnotetext{
${ }^{74}$ Paul Wilson, "Marmet Landowner Hopes to Lure Wal-Mart by Removing the Mountaintop on His Property," Charleston Gazette, November 22, 2003.

75 "New Mayor Proposes Mountaintop Removal," Morgantown Dominion Post, January 12, 2003.

${ }^{76}$ DEIS, Chapter 3, Affected Environment and Consequences, III.T-4, 299.
} 
that this "suggest[s] that the study area is not a major tourism destination.",77 The drafters of this study missed the point. Numbers cannot show what might have been, they can only show what is. No study exists to estimate the loss in tourism dollars in the counties experiencing massive MTR and surface mining because of destruction of land.

The New River Gorge National Park takes up seventy thousand acres in Fayette County, West Virginia. One can easily imagine the magnitude of financial loss that would occur in Fayette County should MTR sites ever move close to this major tourist destination. The natural beauty of the area can sustain many generations of employment and tourist dollars for the county. Other southern West Virginia areas also have beautiful natural surroundings, but enjoy far less success. A combination of physical inaccessibility, lack of advertising, and the ugliness that comes hand in hand with industrial waste all contribute to marring the visual beauty of the unprotected landscapes as do the rusting remains of coal tipples, and scars from the contour and auger mining that transpired throughout the region for decades. Within the last decade, the scars have become larger as MTR has expanded, creating vast expanses of moonscapes and behemoth valley fills.

The economic effects of MTR for these southernmost counties are, superficially, positive but coal is a finite resource that will be exhausted within a few more decades. A Massachusetts Institute of Technology professor hired by the state development office to identify specific industries that the state should target for its development efforts, concluded that manufacturing and coal should continue to be the focus, ${ }^{78}$ but the region must diversify its economy. A June 1998, Register-Herald editorial addressed how Wyoming and McDowell counties were among the poorest counties in the state because of their dependency upon "King Coal." It mentioned

\footnotetext{
${ }^{77}$ Ibid., 300.

${ }^{78}$ Jim Balow, “Don't Leave Coal Out of Future, Consultant says," Charleston Gazette, January 13, 2004.
} 
the development of industrial parks in both counties as well as the first four-lane highway for either county. The editorial also spoke of the development of the Hatfield-McCoy Trail System, an ATV trail system that when completed will span eight southern West Virginia counties, and the amount of tourism dollars this venture is expected to bring to the area. ${ }^{79}$ As of July 2004, the industrial parks and four-lane highway are still being constructed. Using land donated by many land companies, including coal-affiliated land companies, the Hatfield-McCoy trail has opened and one only needs to drive through one of the counties presently receiving traffic (such as Wyoming County where the trail opened in Spring 2004) to see the efforts the residents have made to attract tourists to their respective goods and services. The trail has the potential to be an economic boom for the financially strapped area, and handmade signs have sprouted up all over the area welcoming rider of the Hatfield-McCoy trail. With 21 percent of riders coming from Ohio, 19 percent from within West Virginia and the remaining 60 percent from the rest of the United States and Canada ${ }^{80}$ southern West Virginia has the potential to receive a much needed economic boost from tourism. The trail is only a very small portion of the tourism industry that southern West Virginia could attract if the natural surroundings are protected. Matt Ballard, executive director of the Hatfield-McCoy Trail Authority, noted, "There's no doubt that this has created an economic impact. You can see the new construction in these towns. What you can't see is that it hasn't just created new businesses and jobs; it's saved existing ones." Ballard highlighted that the entrepreneurship residents experienced was new for the area and "is a way for southern West Virginia to take control of its own destiny." ${ }^{81}$

\footnotetext{
79 “Economic Diversity Key to Region's Future," Raleigh Register-Herald, June 29, 1998.

80 "Hatfield-McCoy Trail System Revives Coalfield Economies," West Virginia University Daily Athenaeum, April 29, 2003.

${ }^{81}$ Ibid.
} 
While certainly not the holy grail, the trail and other such tourism ventures provide a very real present addition and potential alternative to complete coal dependency and illustrate the region's eagerness for new economic opportunities. Potential negative environmental impacts from the trail remain to be seen and certainly should be explored. Still, massive strip mining such as that associated with MTR and a healthy tourism industry can not co-exist. Former state senator Si Galperin perhaps stated it best in his 1971 appearance before the Mines and Mining Sub-Committee of the U.S. House Interior Committee which was debating the regulation of the surface mining industry:

"Both stripping and the recreation and tourist industry which employs four times as many people are today growing rapidly. But they cannot both continue to grow. One must force out the other. Either we will have a state of beauty which West Virginians and Americans can continue to enjoy at great profit to ourselves, or we will have a stripped state enjoyed by none at great profit to a few giant, absentee corporations. ${ }^{, 82}$

The need for economic diversification can not be overstated. Coal is a finite resource and can not be replenished. In the southern coalfield counties that have failed to diversify their economy, coal is an economic albatross. While a few people benefit from direct employment and the higher wages offered by coal mining, these counties consistently have the highest unemployment and poverty rates. In short, coal counties represent the poorest counties in one of the poorest states in the nation. The short-term economic boosts to the coal counties' economies due to MTR are indisputable, but the boosts are just that, short-term. Nevertheless, the number of acres permitted for MTR continued to increase. In November 2003, a nine-month review of

\footnotetext{
${ }^{82}$ Si Galperin, "Testimony at the Edmondson Hearing; part two from Appalachian Strip Mining Information Service," Strip-mining collection, A\&M 2618, Box 1, ff1, West Virginia and Regional History Collection, West Virginia University.
} 
permits showed an increase of 3,727 acres over permitted acreage in 2002, from 8,813 to 12,540 acres. $^{83}$

With the ever present dependency on a one-source economy state government tends to look the other way at increased amounts of environmental degradation since it is often seen as necessary for sustaining local economies. In 2002, Jim Pierce, a West Virginia Department of Environmental Protection engineer, when talking about regulations on the coal industry that limit coal sediment admitted that the regulations were not working. The purpose of the law was to diminish disaster risks to a "tolerable level." He went on to make the following analogy, "When you get on an airliner, it might crash. It's deemed a tolerable risk because they don't crash every day but when they do, it's bad. We put up with the small risk because we reap much bigger benefits. Mining's the same way." ${ }^{84}$ These comments seem startling coming from an agent of the state's Department of Environmental Protection. Such an analogy is fallacious on its surface since those who choose to board a plane realize and assume the risk when traveling by airplane. Residents of a rural area impacted by MTR are not in the same position. Actually, only those working on the mining operation would be in a position to realize and assume risk. One would assume that the Department of Environmental Protection would be more concerned with protecting the state's citizens than calculating risks for the companies.

Those elected to the state legislature are also frequently affiliated with coal interests. The coal industry has always exerted considerable political power in the state, and those who have challenged that authority have found themselves at the losing end of many political races. It is widely regarded as an unquestioned truth that state policy, those forging it, and the agencies responsible for enforcing the laws have bent over backwards to appease and please the coal

\footnotetext{
${ }^{83}$ Ken Ward, Jr., "Strip-mined Acreage Up Again in W.Va.," Charleston Gazette, November 4, 2003.

${ }^{84}$ Sam Truman, "Mining \& Money: Supporter, Opponents Clash on Effects of Surface Mining, Reclamation," Charleston Daily Mail, June 14, 2002.
} 
industry. It is also widely believed that the state serves the benefit of the out-of-state coal companies at the expense of its citizens. A guest column in the Charleston Gazette expressed this tautology in declaring that MTR could be justified only if the state forced the coal companies to serve the public interest rather than forcing the people to serve coal. ${ }^{85}$

Alliance of the state's politicians with coal interests is easily traceable through campaign contributions and is a tradition in West Virginia. Senate President Earl Ray Tomblin received $\$ 11,925$ (or 11 percent of total contributions) for his 2000 re-election bid from the coal interests. ${ }^{86}$ This donation was second only to the gaming interests which was attempting to assure passage of legislation that would expand and legalize video gambling machines. ${ }^{87}$ During the 2002 elections, coal donated $\$ 332,252$ to various state senate and house races compared with $\$ 8,520$ donated by environmental groups. In the House, Speaker Bob Kiss received $\$ 10,400$ from coal interests, his second highest contributor behind health professional special interest groups who had an interest in malpractice litigation. Before Bob Wise decided not to run for reelection, coal had donated $\$ 187,400$, or 17 percent of the total amount to his campaign. ${ }^{88}$ Donations by the coal interests often included candidates from both major political parties, thus ensuring allegiance from whoever won the race.

Current federal politicians also show their bias towards the coal industry. West Virginia's congressional delegation frequently protects the industry by fighting against the passage of hostile legislation, or attaching riders onto bills to ensure favorable treatment for the

\footnotetext{
${ }^{85}$ John McFerrin, “Mountaintop Removal is Harmful Tool of Dying Industry,” Charleston Gazette, January $18,1999$.

${ }^{86}$ West Virginia People's Election Reform Coalition: Common Cause West Virginia, Ohio Valley Environmental Coalition, West Virginia Citizen Research Group, and West Virginia Citizen Action Group, 2000 Election Cycle Report available from http://www.wvcag.org/issues/clean_elections/perc2000.pdf, October 5, 2004.

${ }^{87}$ See various articles in the Charleston Gazette and Charleston Daily Mail from 1998-2000 that look at the issue of legalizing these machines.

${ }^{88}$ West Virginia People's Election Reform Coalition: Mountain State Education and Research Foundation, Ohio Valley Environmental Coalition, and West Virginia Citizen Action Group, 2002 Election Cycle Report available from http://www.wvcag.org/issues/clean_elections/perc2002.pdf, October 5, 2004.
} 
coal industry. Frequently cloaked under the guise of helping their constituency, time and again that has been proven not to be the actual case, especially in the case of MTR where the majority of West Virginians are soundly against the practice. Only one representative, Nick J. Rahall, II, could logically say he is voting the conscience of his constituency although even that assertion would be questionable considering that a recent poll of West Virginia voters showed that a full 54 percent of southern West Virginians, encompassing the district that Rahall represents, oppose MTR while only 27 percent favor it. The other 19 percent remain undecided. ${ }^{89}$ West Virginia's other two congressmen represent parts of the state where MTR is not so readily utilized, or in the case of senators, represent the entire state. U.S. senators who embrace these bills supporting MTR actually go against the majority of their constituents. They may truly believe that they are helping the state, but in the end they are doing more harm than good. The continuation and expansion of MTR only hastens the death knell for many small, southern West Virginia communities, and prevents the diversification of the economy that is so essential to the lifeblood of these communities. Focusing development strategies strictly on the coal industry actually inhibits other industries from entering the state.

Nick J. Rahall, II, was first elected to the United States Congress in 1976 and began his freshman term in 1977. Since that time, the people of southern West Virginia have continually elected him as their representative. Throughout his career he has championed himself as a defender of the coal miner and coal mining safety issues. To this end, he has been a very vocal advocate for coal miner's health benefits, black lung issues, and for coal mining safety legislation. He has also been active on issues concerning veterans and the Appalachian Regional

\footnotetext{
${ }^{89}$ Lake, Snell, Perry and Associates, New Poll Findings On Mountaintop Removal in West Virginia. Opposition to Mountaintop Removal is Broad and Deep (Washington, DC: Lake, Snell, Perry and Associates, 2004), available at http://www.appalachian-center.org/poll_results/index.html. Conducted for Appalachian Center for the Economy and the Environment, July 14, 2004.
} 
Commission (ARC), both of which are concerns for the southern West Virginia populace. But he has also been squarely behind MTR. Rahall attributes the problems with MTR to inadequate legal enforcement, not the practice itself. In this assertion he has been consistent. In 1998, he joined with then Congressman Bob Wise in calling for Office of Surface Mining (OSM) scrutiny of the post-mining land use for coal companies granted an MTR variance in southern West Virginia. The duo were responding to a Charleston Gazette exposé which revealed that a full 75 percent of mines permitted for MTR were not granted an approximate original contour (AOC) variance. Approximate original contour, as defined within SMCRA, requires surface reconfiguration through backfilling and degrading of the mined area so that the surface resembles the land prior to mining and blends into and compliments the drainage pattern of the terrain. ${ }^{90}$ The drafters of SMCRA compromised by putting in wording so that the land would have to be returned to its $\mathrm{AOC}$, and also mandated that companies would have to state postmining uses for the land before the company received a permit. In order to receive an AOC variance, the company must show that the now mined land is going to be used for a greater and higher purpose. This would have required the coal companies to present post-mining plans showing the area would be used for an equal to, or better use than, it was before mining. An AOC variance is mandated for MTR mining. ${ }^{91}$ For his part, Rahall had called for closer regulation of MTR in southern West Virginia by the Office of Surface Mining (OSM). Specifically, Rahall called for a crack-down on the post-mining use of mined land as outlined in SMCRA, specifically to be used for industrial, commercial, residential, or public use. Rahall

\footnotetext{
${ }^{90}$ Squillace, Stripmining Handbook, 137.

${ }^{91}$ Ken Ward, Jr., "Wise, Rahall Blast Coal Permit Process," Charleston Gazette, May 5, 1998.
} 
emphasized that the people of southern West Virginia should have economic opportunities in exchange for the variance allowed to mine via MTR. ${ }^{92}$

True to form, Rahall stated: "This is not a case of whether you are for or against mountaintop removal operations. This is a matter of whether or not there has been compliance with federal law as it relates to how permits for these types of operations are reviewed and granted. ${ }^{93}$ He has also pointed out that obtaining an AOC variance comes with the price of viable post-mining land use such as "industrial, commercial, agricultural, resident or public facilities." Rahall noted that this rule was designed so that local inhabitants are left with something economically viable "once the coal is gone." ${ }^{94}$ In a December 21, 2002, RegisterHerald interview, Rahall vehemently supported MTR. He postulated that regulators had not made the coal companies adequately prepare and that this inadequacy of preparation had led to present court cases. As a freshman congressman, Rahall helped draft the Surface Mine Control and Reclamation Act (SMCRA). He stated that SMCRA was a "give-and-take" piece of legislation and was "an effort to head off those who wanted to abolish strip mining completely." He pointed out that there was never any intent to abolish strip mining because it provided jobs, and that he believed reclamation could be done effectively. Rahall proclaimed: "I support the law $\left[\right.$ SMCRA] and it does allow mountaintop mining. ${ }^{.95}$ On the topic of the Clean Water Act, in a 2002 interview Rahall asserted that "the fill material from a mountaintop operation is properly regulated under section 404 of the Clean Water Act." He also affirmed that he did not agree with the buffer zone ruling of the Bragg v. Robertson case, and was pleased that the ruling was

\footnotetext{
${ }^{92}$ Ken Ward, Jr., "Congressman Criticizes OSM: Agency Must Improve Mountaintop Removal Efforts, Rahall says," Charleston Gazette, February 28, 1999.

${ }_{93}$ Ken Ward, Jr., "Wise, Rahall Blasts Coal Permit Process," Charleston Gazette, May 5, 1998.

${ }^{94}$ Ken Ward, Jr., "Rahall Blasts OSM; Wise Wants Permit Moratorium," Charleston Gazette, August 11, 1998.

${ }^{95}$ Mannix Porterfield, “Rahall Stands by Mountaintop Mining," Raleigh Register-Herald, December 21, 2002.
} 
overturned on appeal. He stated that he believed that regulatory improvements were being made in West Virginia as a result of the Bragg v. Robertson settlement, and that he had "always found that all the coal industry wants to know is what the rules of the games are. They will, for the most part, abide by those rules of the game." The article also contains a picture of Rahall in his DC office with the caption "Rahall, friend of the coal industry." 96

Nevertheless, Rahall is concerned with the environment of West Virginia. The Wilderness Society even awarded him one of their highest honors in Summer 2004, naming him the Ansel Adams Award winner for his "lasting contributions to the stewardship of America's natural treasures." ${ }^{97}$ In June 2004, both he and fellow West Virginia Congressman Alan Mollohan called for an investigation of the environmental impact of windmills on West Virginia's environment. Both Mollohan and Rahall were concerned with the effect these large constructions would have on the tourism industry in the heavily visited Potomac Highlands section of West Virginia. Mollohan declared that "[T]here is nothing more beautiful than my West Virginia hills.... and I don't need windmills to re-landscape God's glory and my West Virginia hills." ${ }^{.98}$ Rahall shared the sentiment stating:

"We now have a situation where speculators are staking claim to some of our most scenic areas and erecting these monstrosities that produce little energy and are only made possible by a tax credit. [N]obody has examined the impact these facilities will have on our people and wildlife....Folks go to visit places like Pocahontas County to hunt, fish, camp, canoe, hike and bike, not to stare at giant wind scrapers straddling the ridgetops.... When they stand at the top of Snowshoe Mountain, I think people would prefer to see the beautiful, unending vista that is there today, not a view horribly marred by a phalanx of steel-girder pinwheels." 99

96 "West Virginia Congressman Lends Perspective on Mining Issues," Coal Age, March 2002, available from, http://coalage.com/ar/coal_west_virginia_congressman/index.htm; for further discussion of Bragg v.

Robertson, please see Chapter Five.

${ }^{97}$ The Wilderness Society, press release, "Rahall Wins Ansel Adams Award for Efforts to Protect Nation's Lands" (Washington, DC: the Wilderness Society, June 2, 2004).

${ }_{98}^{98}$ Ken Ward, Jr., "Congressmen want Windmill Study," Charleston Gazette, June 27, 2004.

${ }^{99}$ Ibid. 
Granted, an environmental impact study is appropriate for any activity that might affect the environment, but digging in on wind turbines seems a bit disingenuous considering the position of congressmen Rahall and Mollohan on the massive devastation caused by MTR. These sites also represent what once were "beautiful West Virginia hills," and numerous environmental impact studies have demonstrated its negative impact on West Virginia's environment. Still, no collective outcry exists from West Virginia's elected delegation on this issue. Mollohan feared this harnessing of wind power would result in the continuation of West Virginia as a periphery region with the money made flowing outside of the region. ${ }^{100}$ That is a very real concern given that the majority of West Virginia's natural resource money does, indeed, flow outside of the region with the major players have headquarters in places like St. Louis, Missouri (Arch), and Richmond, Virginia (Massey). The ownership of West Virginia's coal resources was determined generations ago, but wind energy is a new, infinite, and renewable resource. It is a precarious tightrope these congressmen walk, speaking out against potential West Virginia environmental degradation due to windmills on the one hand, and embracing the proven detrimental practices of mountaintop removal on the other. When contacted by this author about his position on MTR, congressman Rahall was consistent in his support of the process while lauding the environmental regulations that many coal operators fear. Rahall noted that it was Clean Air Act regulations, for example, that has led to the increased demand for southern West Virginia coal. He also noted that the upsurge in demand has led to an increase in MTR mining. While admitting that not all MTR coal companies follow federal regulations, Rahall claimed that "there is a proper place for mountaintop mining, and that when

${ }^{100}$ Ibid. 
all is said and done, when all of the court challenges are disposed of, it will continue although perhaps on a smaller scale."101

Of all the current West Virginia congressional delegates, Jay Rockefeller is the only delegate who has had a 180 degree turnaround. Rockefeller first entered West Virginia in 1964 as a Vista Volunteer. He soon became part of a movement actively working to halt strip mining. In 1970, then Secretary of State Rockefeller ran for governor. In that same year, he provided personal funding to support a group of strip mining opponents called Citizens Against Strip Mining (CASM) ${ }^{102}$ At this time, he was an active, outspoken opponent of strip mining. Soon after he helped establish CASM, Rockefeller voiced this opposition publicly, noting that he would have then state Senator Si Galperin introduce a strip mining prohibition bill at the beginning of the state legislature. ${ }^{103}$ He gave a heart-felt speech at Morris Harvey College (now University of Charleston) in 1972 in which he declared that "It's not enough just to be against strip-mining. In the emotion of seeing a newly-clobbered hill, it's easy to forget the larger justification for abolition. The strongest arguments, other than environmental ones, can be made for abolition on economic terms. And we have to manifest concern for new industries and jobs in West Virginia." ${ }^{104}$ [Further excerpts from that fiery speech can be found in Appendix 1.]

Rockefeller ran his gubernatorial campaign on a platform of anti-strip mining, and for the first time West Virginians witnessed an important state political contest focused on the environmental and economic destruction of coal mining. While admitting negative impact that prohibition might have a negative impact on the economy, Rockefeller pointed out that a

${ }^{101}$ Jim Zoia for Congressman Nick J. Rahall to Shirley Stewart Burns, September 28, 2004, electronic letter, Congressman Rahall General Position Paper on Southern West Virginia Coal.

${ }^{102}$ Montrie, "To Save the Land and People," 194.

${ }^{103}$ Ibid., 199; Strip Mining Collection, box 1, ff1, WVRH. ff1, WVRH.

104 "Excerpts from a speech at Morris Harvey College," January 15, 1972, Strip Mining Collection, box 1, 
miniscule number of people were required to work a strip mine, in fact, less than one-half of 1 percent of West Virginia workers were employed in strip mining. He addressed the idea of the loss of tax revenue resulting from such a ban by proposing a severance tax on deep-mined coal. His detractors stated that he underestimated the number of people who would be left unemployed, and also charged that he was leading an assault against property rights. Rockefeller even spoke in favor of the state's anti-strip mining legislation during the 1971 legislative session. ${ }^{105}$ While Rockefeller was successful in winning the Democratic nomination - and doing so against opponents heavily funded by coal industry dollars - he lost the general election to Republican Arch Moore. Rockefeller erroneously believed that his defeat was because of his anti-strip mining stance, but in most other state races during the same election, the opponents soundly defeated strip mining proponents. ${ }^{106}$ Still, this loss convinced Rockefeller that he must join the ranks of strip mine proponents or be an "also-ran." After his conversion he became an advocate of strip mining in the state, justified on the grounds of jobs and economic need. It is a position he holds to the present, encompassing MTR as well as traditional strip mining methods. In response to an inquiry by this author, Rockefeller was the most vehement of both West Virginia senators and Congressman Rahall in extolling the virtues of MTR. He proclaimed that he felt the issue was important, encouraged both sides to talk, and that he took "every job in West Virginia seriously, and will continue to do my best to find a way to prevent the economic harm that this controversy has caused and threatens." Rockefeller's mention of the environment in this correspondence was minimal. He referred to it only in passing while commenting on his hope that all parties can agree on how to preserve the economically important process while

\footnotetext{
${ }^{105}$ Montrie, "To Save the Land and People," 200, 206.

${ }^{106}$ Ibid., 215-216.
} 
"preserv(ing) the land and surroundings as much as possible" and that he hoped for a "solution that would provide peace of mind about both the jobs at stake and the environment."107

Robert Byrd is a West Virginia institution, having had roads, schools, and even higher education facilities named in his honor. His influence throughout the state is deep and his legacy secured. He became a United States congressman in 1953, and began his long tenure as one of West Virginia's senators in 1959. The role of senator is one that he is still actively fulfilling. He frequently works on miners' issues, particularly health and safety, and has recently secured funding for a Coal Mine Impoundment Location and Warning System to monitor impoundments and to educate people living near these impoundments about the danger that is around them. On the topic of MTR, Byrd is united with other members of West Virginia's congressional delegation in staunchly supporting mountaintop removal. After the 1999 Bragg $v$ Robertson ruling, which halted valley fills on the grounds that they were illegal under the Clean Water Act, West Virginia's congressional delegation quickly formed a band of brothers to repudiate the decision. Judge Charles Haden's decision noted that he was merely interpreting the laws as written and should a change be necessitated, then it was up to the legislative branch to do so. In a joint letter to the Charleston Gazette, West Virginia's congressional delegates committed themselves to do just that. In their own words they "urged the U.S. Army Corps of Engineers, the Department of the Interior, and the Environmental Protection Agency to join in an appeal of the court's ruling." 108 They also stated that they were "aggressively examining possibilities for a balanced legislative remedy." This was an obvious allusion to the rider that Senator Byrd would soon after try to push through the senate.

\footnotetext{
${ }^{107}$ United States Senator John D. Rockefeller to Shirley Stewart Burns, personal letter, January 21, 2005.

108 Senators Robert Byrd and Jay Rockefeller and Representatives Nick Rahall, Bob Wise, and Alan Mollohan, "Balance Needed in Mining Issue," Charleston Gazette, November 7, 1999.
} 
In October 1999, after Federal Judge Charles Haden ruled in favor of the plaintiffs in the highly publicized Bragg v Robertson anti-mountaintop removal case, Byrd led the attack against the decision. The top Democrat on the Senate Appropriations Committee, Byrd used his influence to persuade the Clinton White House to side with the pro-mountaintop removal rider Byrd planned to place on a very important spending bill. Not only would this rider have effectively negated Haden's ruling, it would have allowed the "dumping of thousands of tons of mining waste onto federal and Indian land." Leading the western contingency was Senator Larry Craig, a Republican from Idaho. Outsiders may find such an alliance strange, but as Craig put it, "Politics makes strange bedfellows. I would not be uncomfortable in Bob Byrd's bed."109 Soon, the two senators would work together to try to attach a rider that would fit both their needs. Along with the other West Virginia lawmakers, Byrd postulated that West Virginia's elected officials were merely attempting to ensure the state's viability through protection of its most prolific industry thus saving thousands of jobs. Byrd's rider was merely following through with a promise the lawmakers had made to the West Virginia people upon hearing Judge Haden's decision, and President William J. Clinton's White House was going against its own conservation stand by siding with Byrd. The same White House which had vetoed other bills because of their anti-environmental position was set to sign off on a bill that would have given coal companies carte blanche in the dumping of mining waste into West Virginia's streams. ${ }^{110}$ After Haden stayed his decision, the White House pulled back its support, stating there was now no need for the amendment.

\footnotetext{
${ }^{109}$ Francis X. Clines, "With 500 Miners as a Chorus, Byrd Attacks Court Ruling," The New York Times, November 10, 1999.

${ }^{110}$ Tom Kenworthy and Juliet Eilperin, "White House Backs W.Va. on Mine Dumping; Conservationists Say Action Undermines Vetoes, Conflicts with Environmental Stance," The Washington Post, October 30, 1999.
} 
Standing on the floor of the senate in November 1999, Byrd angrily decried the judge's decision and the Clinton administration's initial reluctance to support his rider. In the speech on the senate floor, the West Virginia elder statesman declared, "Fie on the White House! Fie for attempting to mislead the people." He proclaimed that he was speaking up for the coal miners, railway workers, truckers and suppliers that would be affected by Haden's decision. He derided those against mountaintop removal as "head-in-the-clouds individuals [who] peddle dreams of an idyllic life among old growth trees." "111 A Charleston Gazette editorial observed that Byrd's speech "contained misinformation and divisive rhetoric that cast opponents of current mountaintop-removal practices as heartless, mindless individuals...ignoring the real need for jobs."112 In fact, Byrd's speech drew a clear line between hard-working miners and "head-inthe-clouds" environmentalists whom Byrd painted as caring nothing for the plight of the families and economy of the southern coalfield communities. "What do they care [about the loss of income]," the senator stormed, "They will have already thrown down their placards and their banners and gone off somewhere else... These dreamers would have us believe that if only our mountains--if only our mountains--remain pristine, new jobs will come."113

This rhetoric was as divisive as it was wrong. Many of the most vocal protestors to MTR are people who live and work in the communities affected. Some were once underground coal miners themselves. He was also misleading in his assertion that,

"No laws would be weakened by the Byrd-McConnell amendment. No regulations would be discarded. The legislative remedy that is proposed by this amendment is not an either/or proposition. This amendment would permit carefully controlled mountaintop mining while allowing work to continue on a broad environmental study

${ }^{111}$ Senate, Senator Robert Byrd of West Virginia speaking to the Senate on mountaintop mining. Congressional Record (18 November 1999), S14783.

112 “Lord of the 'Fies' Defeat Gives Everyone Time," Charleston Gazette, November 24, 1999.

113 Ibid. 
that could spur better oversight and more environmentally friendly mining practices nationally in the years ahead. In my book, that is a win/win situation."

In fact, the amendment as proposed would have greatly weakened the Clean Water Act. The amendment, No. 2780, was proposed on November 18, 1999. Byrd's rider would have legalized the unofficial "dredge and fill" permits that coal companies had been using when obtaining permits for valley fills. Haden had concluded that this permitting was illegal under the Clean Water Act, section 404 because it provided a "more lenient, less protective standard" to these fills than had been intended by the CWA or by the buffer zone rule of SMCRA. The wording of the proposed rider would have "exempt[ed] valley fills from state and federal water quality standards."115 Byrd's speech before his peers indicated that he was concerned with the working man. He specifically mentioned the dangerous roads many would have to travel to obtain employment if Haden's ruling remained unchanged. "You do not have to drive the dangerous, winding, narrow roads over which these workers would have to commute each morning and evening." "116 The elder statesman did not address, however, the dangerous road residents must face everyday due to massive coal trucks traveling roads designed for lighter weights. The senator then launched into a long diatribe against the perils of coal mining that he has witnessed. Interestingly, everything he mentioned pertains to underground, not surface, mining.

In spite of the rhetoric and coercive tactics, Byrd's rider ultimately failed. While still a fervent supporter of MTR, Byrd and the other members of West Virginia's federal delegation have been more restrained in their comments since 1999, and have not employed the incendiary language that lit the newspaper columns in the latter half of that year. This may be because of a

${ }^{114}$ Senate, Byrd, S14781.

${ }^{115}$ Ken Ward, Jr., "Clinton Backs off Mining Rider: Byrd Legislation Unnecessary in Light of Stay, White House Says," Charleston Gazette, October 31, 1999.

${ }^{116}$ Senate, Byrd, S14784. 
series of court decisions which have been overturned on appeal to the notoriously conservative Fourth Circuit Court of Appeals where all West Virginia federal judicial decisions must go on appeal. The judicial branch's ultimate decisions have made such outbursts unnecessary. The senior senator's response to this author's inquiry regarding his position on MTR verified his recent silence stating that these decisions were "under judicial review in recent years" and that "as a U.S. Senator" he had "no voice in such decisions.","17

At the same time Byrd was pushing his rider, other politicians, outside the coalfield region were imploring President Clinton to uphold the letter and intent of the Clean Water Act, and to veto any such rider that may come across his desk. Clinton, however, waffled when it came to Byrd's ambitious rider. Apparently, he feared retaliation from a powerful fellow Democrat more than he feared a backlash from his environmental constituents. While the defeat of the rider spared Clinton from having to make such a decision, his administration entertained the idea of appealing Haden's decision against valley fill waste dumping and even considered changes to the Clean Water Act that would have given the Army Corps of Engineers the authority to issue permits for MTR sites. ${ }^{118}$ Up to that point, under the agency's own rules, the Army Corps of Engineers had been doing so illegally as their own regulations asserted that the agency was not supposed to allow fill material used to dispose, primarily, of waste. In 1989, a judge ruled that the overburden from mining sites, including all MTR sites, was waste material. In 1999, Judge Haden further clarified the situation by declaring that since the overburden was waste, the Corps could not legally permit the overburden to be dumped under section 404 of the

${ }_{118}^{117}$ United States Senator Robert C. Byrd to Shirley Stewart Burns, personal letter, September 17, 2004.

118 "Slicing Peaks, Burying Streams," The Washington Post, April 13, 2000. 
Clean Water Act. ${ }^{119}$ Again, Clinton received pressure not to proceed. This time from twentythree members of the House who wrote, "Any change that has the effect of allowing valley fills to destroy waters of the United States is unacceptable [and] would be wholly inconsistent with Congress' purpose and intent when it enacted the Clean Water Act.",120

While West Virginia's congressional delegation vacillated between silence on the issue of MTR and an outright protectionist stance, other members of Congress were not so silent. Most vocal of these were Representatives Christopher Shay (R-Conn) and Frank Pallone (D-NJ). Their legislation, reintroduced in February 2003, would codify Judge Haden's original decision in KFTC v. Rivenburgh into law. Upon introducing the legislation, Pallone remarked,

"Our bipartisan legislation is needed to ensure our streams and waterways aren't buried under millions of tons of mining and other industrial wastes. While the legal debate continues, it is critical that we support the true intentions of the Clean Water Act and oppose the continued efforts of the Bush Administration to use our nation's waterways as dumping grounds for industrial wastes."

Shays concurred,

"It is my hope this legislation signals to the EPA that Congress will not sit silently by as our environment is destroyed. We cannot afford to waste another day, another hour, another minute if we want our children and our children's children to enjoy clean water. We simply won't have a world to live in if we continue our neglectful ways.",121

The bill had fourteen other sponsors, none of them a member of West Virginia's delegation. ${ }^{122}$ Since its initial introduction, forty-eight other members have signed on to bring the total co-sponsorship to sixty-four. Still, none of West Virginia's delegation have signed

${ }^{119}$ Ken Ward, Jr., "Valley Fill Rule Rewrite Due by April," Charleston Gazette, February 26, 2002; Ken Ward, Jr., "Senate Panel to Hold Hearings on Fill Rule: Toilets, Junk Cars Could Go Into Fills," Charleston Gazette, February 27, 2002.

120 "Slicing Peaks, Burying Streams," The Washington Post, April 13, 2000.

${ }^{121}$ Christopher Shays, press release, February 12, 2003, available from http://www.house.gov/shays/news/2003/february/febpallone.htm.

${ }^{122}$ Ken Ward, Jr., "Bill Would Make Haden Ruling Law," Charleston Gazette, February 17, 2003. 
on. ${ }^{123}$ The proposed legislation, the Clean Water Protection Act of 2003, sought to solidify the definition of fill within the Clean Water Act to include coal waste. In this effort, they hoped to halt any further attempts by the Bush administration to rewrite the Clean Water Act. In proposing the legislation, they noted that the Fourth U.S. Circuit Court of Appeals overturning of Haden's decision made a legislative remedy imperative. ${ }^{124}$ As of November 2004, the proposed legislation had been referred to the House Subcommittee on Water Resources and Environment. $^{125}$

Senator Byrd and the other West Virginia legislators would soon find a true MTR comrade in the White House when George W. Bush became President in 2000. The Texas Republican had courted West Virginia voters and vowed to protect the coal mining interests. Once in office, he kept his promise. While Haden's initial valley fill decision had been overturned by a "jurisdictional technicality," the Bush administration took an idea originally born with the Clinton administration and forcefully pursued it. This new administration was taking no chances with a higher court and by this time other lawsuits had been filed as well. ${ }^{126}$ So, by 2002 the Bush administration had gone to work rewriting valley fill rules to legalize the very same valley fills that coal companies had been allowed to construct illegally for years. ${ }^{127}$ Not only would the new rules approve those valley fills, they would now be so broad as to include nearly anything dumped into a stream, including items typically considered garbage, such as old porcelain bathroom fixtures (including sinks and tubs), junk cars, refrigerators, and

${ }^{123}$ Congress, House, Federal Water Pollution Control Act Amendment to Clarify that Fill Material Cannot be Comprised of Waste, $108^{\text {th }}$ Cong., ${ }^{\text {st }}$ sess., 2003 H.R. 738, Bill Summary \& Status for the 108th Cong. (13 February 2003).

${ }^{124}$ Christopher Shays, press release, February 12, 2003.

${ }^{125}$ Federal Water Pollution Control Act Bill Summary.

${ }^{126}$ In particular, the Kentuckians for the Commonwealth v. Rivenburgh case. Please see Kentuckians for the Commonwealth v. Rivenburgh, U.S.D.C. for the Southern District of West Virginia (May 2002). See Chapter Five, fn 33.

${ }^{127}$ Ken Ward, Jr., "Valley Fill Rule Rewrite Due by April," Charleston Gazette, February 26, 2002. 
the like. The proposed rewrite was backed by both the U.S. Army Corps of Engineers and the U.S. Environmental Protection Agency, and went so far as to declare that these types of fixtures could be "environmentally beneficial artificial reefs." $" 128$ The proposed rule received so many letters (in excess of 17,000 letters) overwhelmingly against the proposed rules that they did not see the light of day.

Then, in May 2002, Haden once again ruled on a valley fill issue. This time, he stopped the Army Corps of Engineers from permitting most valley fills. The only legitimate way the Corps could permit such fills, noted Haden, was if the fills were part of a legitimate post-mining land use. Haden's ruling noted that allowing such dumping under the Clean Water Act in effect "rewrites the Clean Water Act." While noting that the Corps and the US Environmental Protection Agency had tried to do just that a few days prior to his ruling with new rules for the Clean Water Act, he was not swayed, noting that they had overstepped their authority and had no power to rewrite an act of Congress. Furthermore, the Corps had been issuing valley fill permits illegally, he declared, and to continue to issue permits solely because it had been allowed in the past would be a continued disregard of the letter and intent of the law. ${ }^{129}$ While Haden was aware of the economic pressures associated with the continued practice of MTR valley fills, he also understood that there were other issues at hand. In his ruling for the Kentuckians for the Commonwealth v. U.S. Army Corps of Engineers, Haden stated the following, "The Court does not rule in a vacuum. It is aware of the immense political and economic pressures on the agencies to continue to approve mountaintop removal coal mining valley fills for waste disposal, and to give assurances that future legal challenges to the practice will fail. Some may believe that reasonably priced energy from coal requires cheap disposal of the vast amounts of waste material created when mountaintops are removed to get at the natural resource. For them, valley fill disposal is the most efficient and

\footnotetext{
${ }^{128}$ Ken Ward, Jr., "Bush Administration Plan Broadens Valley Fill Rule Changes: Cars, Toilets could be Dumped into Streams," Charleston Gazette, April 26, 2002.

${ }^{129}$ KFTC v. Rivenburgh, 5, 37.
} 
economical solution. Congress did not, however, authorize cheap waste disposal when it passed the Clean Water Act." $" 130$

The Bush administration implored Judge Haden to suspend his ruling until an appeal could be filed, citing the economic consequences of his ruling. Federal authorities also believed the ruling to be overly broad, and that the ruling should have applied only to the mine site in question. ${ }^{131}$ Had Haden only ruled on that particular mine permit, contesting such illegal practices would have placed a heavier burden upon the residents bringing lawsuits. It is easy to understand why the coal industry and the Bush administration so fervently supports such practices; a more cumbersome process would "occupy" citizens unnecessarily while the courts rendered carbon copy decisions based on precedence or the literal interpretation of the law. This time, however, Haden refused to suspend his ruling and was firm in his decision. His decision against granting the suspension was even longer than his initial decision in favor of the plaintiffs. In denying the suspension request, Haden noted that the defendant's argument that "these fills are required and all mines are dependent on them, is demonstrably false. To stay the Court's injunction would be an invitation to coal operators...to save money by continuing their current waste disposal practices, filling miles of Appalachian streams in disregard of the statutory scheme. ${ }^{" 132}$ He clarified that the ruling applied only to the Huntington Corps district as well as to any type of mining pursuing permits by the Corps. ${ }^{133}$ The defendants took up their cause to a higher court, the conservative fourth circuit court in Richmond, Virginia. Once again, the conservative court did not disappoint the coal industry. Haden's valley fill decision was again overturned by the three fourth district justices. Somehow, the trio concluded that the Clean

${ }^{130}$ Ibid., 40, 41; Ken Ward, Jr., "Judge Blocks New Valley Fills: Corps of Engineers' Practice Illegal, Violates Clean Water Act, Haden Rules," Charleston Gazette, May 9, 2002.

${ }^{131}$ Ken Ward, Jr., "U.S. Asks Haden to Suspend Fill Ruling," Charleston Gazette, May 14, 2002.

${ }^{132}$ KFTC v. Rivenburgh, Memorandum Opinion and Understanding, U.S.D.C. for the Southern District of West Virginia (July 2002), 41.

${ }^{133}$ Ken Ward, Jr., “Haden Won’t Suspend Valley Fill Ruling,” Charleston Gazette, June 18, 2002. 
Water Act actually permits dumping coal mining waste into U.S. waterways. ${ }^{134}$ Their ruling seemed to ignore the fact that the Corps was the agency issuing these permits, and under the Corps own definitions, that agency would not be allowed to legally issue such permits.

In January 2004, the Bush administration proceeded with its attack on environmental regulations. This time the administration, through the Office of Surface Mining's director Jeff Jarrett, sought to weaken the buffer zone rule of the SMCRA. The purpose of the buffer zone rule was to limit mining activity within 100 feet of intermittent and perennial streams. Bush's proposal would have weakened the criteria for a variance to the buffer zone rule. Instead of having to assure that there would be no water quality violations by issuing a variance, the new rules assured that the company merely had to do the best they could to minimize stream impact using the most current technology available. ${ }^{135}$ At this writing, no decision has been made on that proposal although the Office of Surface Mining expects to issue final regulations by March 2005. ${ }^{136}$ With the protection provided to the industry by a presidential administration firmly in its corner, a conservative federal appellate court poised to overturn most every decision on appeal, the MTR coal proponents have a solid hold on the reigns of power and it would appear will not have to release them anytime soon.

\section{$\underline{\text { Conclusion }}$}

West Virginia continues to act as a periphery region for the rest of the country and its economy remains dependent upon natural resource extraction. Exploitation of the state's resources was aided by a political economy organized to favor industry property rights over individuals' property rights. West Virginia's politicians on both state and federal levels

\footnotetext{
${ }^{134}$ Ken Ward, Jr., "Mine Ruling Tossed: Haden's Valley Fills Ruling Overturned Again,” Charleston Gazette, January 30, 2003.

${ }^{135}$ Ken Ward, Jr., "Fill Rule Removes Stream Protections," Charleston Gazette, January 8, 2004.

${ }^{136}$ Brian Bowling., "Agency Considering Buffer Zone, Ownership Comments," Charleston Daily Mail, April 24, 2004.
} 
historically have been heavily involved with extractive industry, a trend which persists through today. The intricate relationship between industry and politics resulted in economic despair for the coalfield region where economic diversification is extremely unusual.

Increased mechanization associated with MTR has been accompanied by decreased employment. Historically, such increases in demand have boosted employment at least for a short term, but this has not been the present day reality in southern West Virginia's coalfields. Demand for coal is up and coal production continues to climb even as employment dwindles leaving the paradoxical situation of a jobless coal boom in southern West Virginia. ${ }^{137}$ Still, industry and politicians continue to praise the few jobs attributable to MTR, and fight doggedly in the court system to ensure that coal's domination of the state's economy and people remains intact.

${ }^{137}$ McGinley, "From Pick and Shovel to Mountaintop Removal," Environmental Law Vol. 34, No. 1 (2004), 77. 


\section{Chapter Five:}

Showdown in Charleston:

The Judicial System and Mountaintop Removal Surface Coal Mining

"What is not mined today may be mined tomorrow, unless it is determined it cannot be mined under the Clean Water Act, in which case it should not be mined today or in the future."

Judge Charles Haden, II

In the southern coalfields, MTR is regulated by federal and state law. Any state law must be as strict as, or stricter than, the federal law. If a state law is weaker, it is always trumped by the stronger federal law. Most lawsuits brought forth regarding MTR have been based on federal law, or specifically, the state agencies' failure to properly execute their duties under state run and federally approved programs. The two federal laws that are especially important in regulating MTR are the Surface Mining Control and Reclamation Act (SMCRA) and the Clean Water Act (CWA), particularly section 404.

The Clean Water Act provides for the protection of United States' waterways. Enacted in 1972, the CWA regulates the amount of pollutants, both toxic and non-toxic, discharged into U.S. waters. The CWA also regulated the distribution of permits for pollutants released into the nation's waterways. It is in this capacity that the act proved so important to regulating MTR. Section 404 of the Clean Water Act regulated dredge and fill permits and is the section of the law used to permit coal mining valley fills. The act provides states with the power to regulate these permits, and the Army Corps of Engineers the power to issue the permits. Section 404 of the CWA allowed for dredge and fill permits (including valley fills) once the opportunity for public comment through public hearings has occurred. The CWA also allows for nationwide permits. To obtain a Nationwide Permit 21, which is used in surface mining operations, an applicant must satisfy a number of stipulations. Among these are that the activity will not "substantially disrupt the movement of those species of aquatic life indigenous to the waterbody, including those 
species which normally migrate through the area," nor should such carte blanche authority be given if the activity will harm endangered species. Nationwide permits allow for the granting of permits with little to no delay or paperwork and are, therefore, very attractive to companies looking for expediency. These permits are designed for activities that pose little environmental impact. $^{1}$

After years of failed attempts on the federal level to pass legislation to regulate surface mining and to provide guidelines on mandatory reclamation procedures, a compromise was reached in 1977 resulting in the passage of the Surface Mining Control and Reclamation Act (SMCRA). A much weaker bill than had originally been twice proposed during the Gerald Ford administration, it was finally passed and signed into law by President Jimmy Carter. ${ }^{2}$ The government declared the following in its findings section of the law:

"many surface mining operations result in disturbances of surface areas that burden and adversely affect commerce and the public welfare by destroying or diminishing the utility of land for commercial, industrial, residential, recreational, agricultural, and forestry purposes, by causing erosion and landslides, by contributing to floods, by polluting the water, by destroying fish and wildlife habitats, by impairing natural beauty, by damaging the property of citizens, by creating hazards dangerous to life and property, by degrading the quality of life in local communities, and by counteracting governmental programs and efforts to conserve soil, water, and other natural resources."3

Clearly, the framers of the act recognized that much destruction could occur on the local or regional level as a result of strip mining; however, they sought to balance the energy needs of the nation - then suffering from an oil embargo by Arab nations - with the environmental and commercial realities of strip mining. The framers did not, however, downplay the positive effects mining had on the national economy, also stating

${ }^{1}$ Federal Water Pollution Control Act, U.S. Code, title 33, chapter 26, sec. 1251 (2005); Corps of Engineers, Department of the Army, Nationwide Permit Program. Code of Federal Regulations, title 33, parts 330.1(b) and 330, appendix A (2003).

${ }^{2}$ For further information on the long, political trip to obtain passage of SMCRA, please see Chapter One.

${ }^{3}$ Surface Mining Control and Reclamation Act of 1977, U.S. Code, title 30, sec. 1201(c) (1995). 
"surface and underground coal mining operations affect interstate commerce, contribute to the economic well-being, security, and general welfare of the Nation and should be conducted in an environmentally sound manner."

From these separate findings it is apparent that while congress recognized the negative impact on local and regional economies, it was willing to sacrifice some of these areas for the good of the nation. The act did allow mountaintop removal coal mining as long as the land was returned to as good as, or higher use. The act also allowed states to oversee themselves in the enforcement of the act's regulations; however, if the "state fails to implement, enforce, or maintain its approved state program, the Secretary has the duty to prepare and implement a federal program for that state. ${ }^{, 5}$ With the inclusion of the reclamation aspect and the Abandoned Mine Reclamation Fund, the act strove to ensure that land disturbed by surface mining was reclaimed and that previously abandoned mine lands had a funding source to ensure their reclamation.

Since 1998, a number of important cases relating to varying aspects of mountaintop removal in West Virginia have occurred. Some of these important cases are reviewed here, looking at the ongoing legal struggle. The first of these cases was the high profile Bragg v. Robertson case of 1998, heard by Judge Charles Haden, II. Faced with the impending annihilation of their homes and the destruction of their property through flyrock, dust, noise, cracked foundations and destroyed wells, a group of coalfield residents brought forth a lawsuit in July 1998. Plaintiffs in the case claimed that the Director of the West Virginia Division of Environmental Protection (WVDEP) violated the Surface Mining Control and Reclamation Act by approving illegal valley fill

\footnotetext{
${ }^{4}$ Ibid., section 1201(j).

${ }^{5}$ Michael G. Crotty, "Bragg v. West Virginia Mining Association: the Eleventh Amendment Challenge to Mountaintop Coal Mining," Villanova Environmental Law Journal 13 (2002): 287-311; SMCRA, 30 U.S.C. 1254(b)-(c).
} 
permits for mountaintop removal. The plaintiffs sited SMCRA's public citizen suit provision as authority for their suit. The provision allows any citizen to sue State regulatory authorities that fail in their non-discretionary duties under the Act.

The Bragg v. Robertson lawsuit claimed that the state Division of Environmental Protection as well as the U.S. Army Corps of Engineers failed to enforce the federal Clean Water Act and allowed the illegal issuing of valley fill permits under section 404 of the CWA. Furthermore, the suit claimed that the Corps of Engineers "lacked jurisdiction" when issuing valley fill permits under section 404 because the waste that comprises the valley fills is excluded under the Corps own definition of fill material. They noted that in 1989, U.S. District Judge John Copenhaver defined strip mine spoil as 'waste'and that the Corps definition of fill does not include such waste. The suit alleged that the Corps had been illegally issuing these permits under section 404 for years. The CWA allowed pollutants to be released into water if the coal company had received a permit from the U.S. EPA or a state regulatory agency.

The Army Corps of Engineers also possessed the authority to issue permits for dredge and fill activities. ${ }^{6}$ At the time of the suit, the Corps admitted that the agency did not have the authority to authorize the dumping of mining waste into waters under section 404 of the CWA. The chief of the Huntington, West Virginia, regulatory branch of the Corps stated that the Corps believed a 1989 court decision did not allow for the permitting of valley fills under Section 404 and that the Corps did not disagree with that assertion. The chief of the Huntington permitting section, Richard Buckley, noted that the Corps "stopped issuing 404 permits for valley

\footnotetext{
${ }^{6}$ Ken Ward, Jr., “Corps says it doesn't Regulate Valley Fills: Stance could Help Suit Over Mountaintop Removal," Charleston Gazette, July 19, 1998; Bragg v. Robertson, 1998 U.S. Dist. Lexis 22077 (S.D. W. Va. 1998); Jack McCarthy, “Judge Upholds EPA's Authority,” Charleston Gazette, December 29, 1989; West Virginia Coal Association v. Reilly, 1989 U.S. Dist. Lexis 15881 (S.D. W. Va. 1989).
} 
fills...after the agency was made aware of [the] 10-year-old court decision." He further stated, "We're not supposed to authorize valley fills." The suit "ask[ed] for a court order that state and federal regulators have improperly permitted hundred of valley fills." 7 The suit was filed against Michael Miano, then director of the WVDEP, for failing in his duties under SMCRA as well as West Virginia state regulations. The suit also named the Army Corps of Engineers and three of its employees for illegally permitting valley fills under Section 404 of the CWA, and for illegally issuing Nationwide Permit 21 "without the required analysis."

In December 1998, plaintiffs agreed to drop the suit against the Corps in exchange for an agreement that the Corps would more closely scrutinize permits, and an agreement to conduct an extensive study on the effects of mountaintop removal. The partial agreement would streamline the permit process as well as produce tougher environmental standards for the coal companies to adhere to. The agreement stipulated that federal agencies involved with MTR would "[r]equire complete environmental assessments for all mine permits larger than 250 acres." ${ }^{\prime 9}$ Still, this agreement did not completely settle the lawsuit.

In November 1998, WVDEP director Miano approved the expansion of Arch Coal's DalTex MTR site near Blair in Logan County. The permit covered 3100 acres and "was the largest issued in West Virginia history." 10 This particular permit had been targeted in the Bragg v. Robertson lawsuit. The federal defendants had asked that this particular permit be exempted from the lawsuit. The plaintiffs in turn asked for a preliminary injunction of the permit until the

\footnotetext{
${ }^{7}$ Ken Ward, Jr., "Corps says it doesn't Regulate Valley Fills," Charleston Gazette, July 19, 1998.

${ }^{8}$ Bragg v. Robertson, October 9, 1998.

${ }^{9}$ Paul Nyden, "Legal Agreement May Save Mountaintops: New Limits Placed on Strip Operations," Charleston Gazette, December 24, 1998.

${ }^{10}$ Ken Ward, Jr., "Controversial Mining Permit Issued: Mountaintop Project to Face Challenges on Several Fronts," Charleston Gazette, November 4, 1998.
} 
suit was settled. ${ }^{11}$ In February 1999, Judge Haden agreed to tour MTR sites and encouraged by plaintiffs in the case, also agreed to a flyover of southern West Virginia MTR sites. On this flight, he witnessed first hand "the extent and permanence of environmental degradation this type of mining produces." He subsequently issued a preliminary injunction halting the permitted expansion. ${ }^{12}$ By June 1999, the Corps concluded that their chances of succeeding in any lawsuit that might occur because of the permit were "minimal" and withdrew their initial approval of the Dal-Tex mine. ${ }^{13}$ The Corps refused to issue a Nationwide Permit 21 to the site and Arch Coal did not "[submit] a permit that regulators and the courts [would] approve." With the permit revoked, in July 1999, 400 UMWA workers at the site were laid off, or had their jobs eliminated entirely. ${ }^{14}$ In July 1999, the citizens and the environmental group involved in the suit signed an agreement with the DEP, the West Virginia Coal Association, and the Western Pocahontas Land Company. The DEP agreed to more stringent regulations which would cause the agency to "enforce federal rules that require companies to rebuild more of the mountains they tear down to reach coal seams" as well as making the industries submit "post-mining development plans," one of which could include free land for low income inhabitants. ${ }^{15}$ The judge warned that this was not the final resolution to the problems.

The opposing sides could not agree on the crucial issue of the buffer zone rule, a rule within SMCRA, specifically whether it forbids valley fills in intermittent and perennial streams. That issue would not be decided until the October 20, 1999, courtroom decision. The Charleston

\footnotetext{
${ }^{11}$ Ken Ward, Jr., "Ruling Sets Up Next Mining Battle: Judge Refuses to Revoke Mountaintop Removal Permit in Prelude to Long Legal Fight," Charleston Gazette, November 10, 1998.

${ }^{12}$ Bragg v. Robertson, Memorandum Opinion and Order granting preliminary injunction March 3, 1999.

${ }^{13}$ Ken Ward, Jr., "Corps Withdraws Arch Coal Permit: 'New Material Facts' Send Federal Agency in Opposite Direction," Charleston Gazette, June 25, 1999.

${ }^{14}$ Ibid.; Ken Ward, Jr., "Dal-Tex Mining to Cease Friday: Shutdown to Put 210 Out of Work," Charleston Gazette, July 22, 1999.

${ }^{15}$ Ken Ward, Jr., "Mountaintop Removal Settlement Filed," Charleston Gazette, July 27, 1999; Ken Ward, Jr., "Haden Schedules Friday Hearing on Mining Settlement," Charleston Gazette, July 28, 1999.
} 
Gazette headline the next day told the story: "Valley fill mining outlawed: Landmark ruling prohibits mountaintop coal operators from burying state streams," it declared and certainly the ruling as written by Judge Charles Haden seemed to indicate just that. ${ }^{16}$ Haden's decision stated that valley fills were only legal in ephemeral streams, those that flow only when rain falls or snows melt. Intermittent and perennial streams must not have valley fill waste and material placed into them. Haden's forty-nine page opinion detailed his reasoning. The defendants had argued that the buffer zone rule did not apply to streams in their entirety so long as portions of the stream remained viable. Haden was not convinced. He concluded that "the buffer zone rule protects entire intermittent and perennial streams, not just portions thereof." He pointed out that provisions in SMCRA noted that "nothing therein 'shall be construed as superseding, amending, modifying, or repealing ...the Clean Water Act." Using a Memorandum of Understanding (MOU) as their basis, defendants argued that Section 404 allowed valley fills. Haden was not convinced, declaring that the MOU was contrary to the CWA and was, therefore, contrary to law. The CWA clearly stated that no pollutants should be allowed into U.S. waterways simply for disposal of waste with no higher land use for the fill. He acknowledged that section 404 might allow valley fills used primarily for land development, along with AOC waivers. Haden then asserted that coal mine spoil is waste and that the Corps did not have the authority to permit waste disposal under section 404 of the CWA. He noted that the Environmental Protection Agency (EPA) was the entity that had the authority, under section 402 of the CWA, to permit for waste disposal. His ruling stated that:

"When valley fills are permitted in intermittent and perennial streams, they destroy those stream segments....If there are fish, they can not migrate. If there is any life that can not acclimate to life deep in a rubble pile, it is eliminated. No effect on related environmental values is more adverse than obliteration. Under a valley fill, the water

\footnotetext{
${ }^{16}$ Ken Ward, Jr., "Valley Fill Mining Outlawed: Landmark Ruling Prohibits Mountaintop Coal Operators from Burying State Streams," Charleston Gazette, October 21, 1999.
} 
quantity of the stream becomes zero. Because there is no stream, there is no water quality."

He went on to proclaim the reality of valley fills as "waste disposal projects so enormous that, rather than the stream assimilating the waste, the waste assimilates the stream."17

Haden's decision rang throughout the region, the state, and the country. With a cacophony of doomsayers at his back, Haden suspended his decision on October 29, 1999, until an appeal could be made to the $4^{\text {th }}$ Circuit Court of Appeals. ${ }^{18}$ At the same time, West Virginia's congressional delegation worked to circumvent judicial recourse through a rider that Senator Byrd planned to attach to a very important spending bill. ${ }^{19}$ A chaotic discourse over the perceived effects of Haden's decision chorused through the state and in the halls of congress.

The coal industry and supporters of MTR rested their hopes for relief on the Fourth Circuit Court of Appeals in Richmond, Virginia. Notorious for their conservative, right-leaning decisions, the Fourth Circuit Court of Appeals did not disappoint. In April 2001, the court failed to address any of the real issues of the case and instead overturned Judge Haden's decision on a jurisdictional technicality. ${ }^{20}$ Subsequently, in 2002, the United States Supreme Court refused to hear the case, thus upholding the appelate court's decision. Mountaintop removal coal mining as practiced in the state would continue. The legal case had broad ramifications for all parties engaged in the coal industry, as well as the plaintiffs of the case, the residents in areas where MTR occurs, the workers at the surface mining sites, the coal companies, the UMWA, and the

${ }^{17}$ Bragg v. Robertson, Memorandum Opinion and Order.

${ }^{18}$ Ibid.; Also, see the Charleston Gazette on any day from October 21 through October 29, 1999, when there appear stories regarding the "consequences" of Haden's decisions. Perusal of local papers in southern West Virginia coal counties reveal the same thing. In particular, the Logan Banner in Logan County was especially vocal going so far as to call the decision a declaration of war (see March 9, 1999, edition "This is War"); the Associated Press released stories across the country where newspapers headlined "Mountaintop removal ban may kill coal, critics say."

${ }^{19}$ For further information on this political struggle, please see Chapter Four.

${ }^{20}$ Bragg v. West Virginia Coal Association, 248 F.3d 275 ( $4^{\text {th }}$ Cir. 2001). Note that while the case is still the same exact case as Bragg v. Robertson, the name of the case changed once the case went to the $4^{\text {th }}$ Circuit. 
environmental and economic health of the communities themselves. Important questions were left unanswered, however, and other lawsuits would soon follow.

In October 2003, the Ohio Valley Environmental Coalition (OVEC), Coal River Mountain Watch (CRMW), and the National Resources Defense Council (NRDC) filed a lawsuit against the Army Corps of Engineers. Once again, the main concern was the permitting process used for valley fills. This time the lawsuit challenged the use of Nationwide Permit 21 (NWP 21 ) in the issuance of permits for valley fills. Lawyers for the plaintiffs argued that NWP 21 permits should only be issued, as mandated by law, when they are likely to cause only minimal environmental damage. The plaintiffs maintained that, on the contrary, the Corps had haphazardly issued NWP 21 permits, resulting in extreme environmental damage including the burial of hundreds of miles of West Virginia rivers. The plaintiffs' argued that the coal companies should adhere to the stricter requirements involved in obtaining individual permits and stressed that the covering of hundreds of miles of streams and the destruction of hundreds of acres of forests does not amount to the minimal environmental impacts stipulated in permitting under NWP 21. The suit listed dozens of valley fill authorizations which were either already approved, or expected to gain approval. The list the plaintiffs provided showed "nearly 64,000 acres of mining permits in a dozen West Virginia watersheds. $" 21$

U.S. District Judge Joseph Goodwin was assigned to the case. He denied requests by coal industry groups and the Corps to throw out the case. The case specifically noted a Nicholas County valley fill permit issued to Green Valley Coal Co. Even though the Corps had agreed to have Green Valley Coal Co. seek an individual permit to fill in part of Blue Branch (which flows into Hominy Creek), on March 25, 2004, the Corps approved a NWP 21 permit for the filling of 431 feet of Blue Branch. On April 6, 2004, acting at the behest of the plaintiffs who had

\footnotetext{
${ }^{21}$ Ken Ward, Jr., "Lawsuit Challenges Coal Mining Permit,” Charleston Gazette, October 24, 2003.
} 
requested an emergency ruling on that particular valley fill, Judge Haden temporarily blocked a Massey Energy permit for a preparation plant waste fill. Granted a ten-day reprieve, the Nicholas County stream that Massey subsidiary Green Valley Coal Co. had prepared to be filled would, for the moment be "spared." While filling in a relatively minute amount of stream (431 feet), Goodwin observed that if covered the stream could not be repaired. At risk was Hominy Creek, the eventual destination for the disposal and home to a high quality trout stream. ${ }^{22}$

The fill would actually have been the beginning of a larger fill for the subsidiary. The smaller fill was proposed to be a temporary, eight-month fix for the company who stated that it needed the area to dispose of fill for the next eight months and to maintain employment for 150 of its workers. The initial proposal to the Corps would have expanded the company's original permit by 75 acres and would have begun dumping into the Blue Branch. The permit would have eventually allowed the placement, per year for at least a decade of " 1.5 million tons of coarse refuse and 510,000 tons of fine refuse into the stream." Green Valley had detailed plans to reroute the stream, and claimed that the water running under the valley fill might even be healthier for the trout because of the coldness of the water. ${ }^{23}$ However, the defendant failed to disclose that if the headwater stream should be filled in, the subsequent loss of macroinvertebrates would be detrimental to the trout population due to the loss of the trout's food source. ${ }^{24}$

Within a week of his earlier order, Goodwin heard further arguments and added another ten days to "his initial temporary restraining order," allowing more time for him to hear further

\footnotetext{
${ }^{22}$ Ken Ward, Jr., “Judge Blocks Massey Permit: Full Hearing is Scheduled for Stream Fill,” Charleston Gazette, April 6, 2004.

${ }^{23}$ Ken Ward, Jr., "Judge Blocks Massey Fill Plan,” Charleston Gazette, April 8, 2004.

${ }^{24}$ Please see Chapter Six for further discussion of this topic.
} 
arguments before deciding the ultimate fate of the fill. ${ }^{25}$ During the court case it was revealed that Green Valley had begun filling in the stream in question even before the Corps had approved the company's proposed mitigation plan. The judge seemed astonished at the revelation and at one point while holding a stack of papers in his hand is quoted as saying to the Corps lawyer, "Is this a mistake? What good does it do to say, 'Go ahead and fill this, and then later provide us all of the information to show whether it will or will not have a significant impact?"'26

On April 26, 2004, Goodwin placed a more permanent halt to the Massey subsidiary Green Valley coal company's valley fill. Acting on a motion for a preliminary injunction or a temporary restraining order in the Green Valley smaller fill issue, the Judge agreed with the plaintiff's lawyer that the Corps illegally "broke up" the initial permit request into two smaller requests to "avoid a more detailed environmental review." In his decision, the judge ruled that the approval of the smaller fill (called Revision 5) was "an abuse of NWP 21" as all documentation in the case made it apparent that the company had not re-written any mitigation plans. Instead, it had utilized the prior mitigation plans for the larger fill permit and fully planned to obtain that permit which would have diverted 8,000 feet of stream for 431 feet of valley fill within the stream. The judge's decision was clear on this, "the destruction of 431 feet of a stream's small tributary by diverting 8,000 feet of the stream itself is ridiculous. The plan to mitigate so little damage with so much disruption to the watershed is as absurd as the statement by the officer in Vietnam that he had to 'destroy the village to save it."' Goodwin was just as clear in his findings, writing that "the public interest weighs in favor of OVEC. The public has

\footnotetext{
${ }^{25}$ Ken Ward, Jr., “Judge Adds 10 Days to Order Blocking Massey Stream Fill,” Charleston Gazette, April $13,2004$.

${ }^{26}$ Ken Ward, Jr., "Massey Fill Started Before Permit Plan Complete, Judge Told," Charleston Gazette, April 23, 2004.
} 
an interest in the integrity of the waters of the United States, and in seeing that administrative agencies act within their own regulations."27

Still, the case was not completely settled. The larger issue of the Corps using NWP 21 permits for valley fills still remained unresolved. On July 8, 2004, Judge Goodwin delivered his decision. "The Army Corps of Engineers could no longer approve mining valley fills through a streamlined permit process meant only for activities that cause minor environmental damage."28 Goodwin ruled that the Corps had been issuing the NWP 21 permits in violation of the Clean Water Act, and he also stipulated that in addition to halting such permitting in the future the Corps must revoke eleven permits it had previously allowed where construction had not yet commenced. $^{29}$ On July 22, 2004, OVEC requested an expansion of the judge's original order to include six more permits that the plaintiffs had not known about because, according to the plaintiffs, the Corps had been very secretive about those permits. On August 13, 2004, he granted that request. ${ }^{30}$ A subsequent request by the plaintiffs to clarify the ruling was denied. In refusing the request, Goodwin declared that his orders were unambiguous and that he believed the Corps could enforce them as is. ${ }^{31}$

While the Bragg v. Robertson case faced more vocal critics, the OVEC v. Bulen decision was still met with cries of ruination and economic upheaval from the coal industry. By September 2, 2004, the Bush administration announced its plans to file an appeal with the Fourth

${ }^{27}$ Ohio Valley Environmental Coalition, et al. V. William Bulen, 315 F. Supp. 2 d 821 (S.D. W. Va. 2004); Ken Ward, Jr., "Environmental Group seeks Quick Ruling in Mining Case," Charleston Gazette, May 12, 2004.

${ }^{28}$ Ken Ward, Jr., "Goodwin Mine Ruling 'Whole New Ballgame,"”Charleston Gazette, July 18, 2004.

${ }^{29}$ Chris Wetterich., "U.S. Judge Curtails Valley Fills. Environmentalists See Big Win in Fight Against Mountaintop Removal," Charleston Gazette, July 9, 2004; Ohio Valley Environmental Coalition, et al. v. William Bulen, Memorandum Opinion and Injunctive Order, Civil Action Number 3:03-2281 (S.D. W. Va. July 8, 2004).

${ }^{30}$ Martha Bryson Hodel, "Judge Asked to Expand Ruling on Valley Fills: Environmentalists Cite Six Other Mines," Charleston Gazette, July 23, 2004; Ken Ward, Jr., "Judge Expands Ruling Blocking Coal Mines from getting Simplified Fill Permits," Charleston Gazette, August 14, 2004.

${ }^{31}$ Ken Ward, Jr., "Goodwin Declines to Clarify Mountaintop Removal Ruling," Charleston Gazette, September 1, 2004. 
U.S. Circuit Court of Appeals. Bush's senior environmental policy adviser, Jim Connaughton, made the announcement at the state Chamber of Commerce's annual luncheon at the Greenbrier Resort in West Virginia. As of the September gathering there had been no layoffs or work stoppages correlated with the decision, yet naysayers asserted that it was only a matter of time. ${ }^{32}$ As of October 1, 2004, no date had been set for the appeal. Still, supporters of MTR can take heart that the Fourth U.S. Circuit Court of Appeals has not failed to overturn any of the MTR environmental decisions that have come to them from West Virginia's District Courts and the trend is likely to continue. ${ }^{33}$

The 1889-1909 West Virginia Supreme Court adopted a "reasonable use rule" intended to acknowledge the rights of both agriculture and industry in nuisance disputes. At the center of this rule was the "scale of reasonableness" in property use. Rather than one side being preferred, the court concluded that both interested parties had a right to enjoy their property, even if there were competing interests. ${ }^{34}$ In its application, however, there was a fundamental departure from traditional court rulings. The old court rested on the foundation of the universal principle of natural rights centering on the belief that everyone had a right to use their property so long as it did not infringe on another's rights. The new court, however, embraced legal positivism which

${ }^{32}$ Lawrence Messina, "Corps to Appeal Federal Mining Ruling," Associated Press, September 2, 2004.

${ }^{33}$ While not dealing specifically with MTR in West Virginia, the Fourth Circuit Court also reversed another Judge Charles Haden decision in a case called Kentuckians for the Commonwealth v. Rivenburgh. The lawsuit hoped to stop the burying of six miles of Kentucky streams beneath twenty-seven separate valley fills. Again, Haden ruled for the plaintiffs and the permittee in question, Beech Fork Processing, even admitted that they could mine the coal without the valley fills. Upon appeal, the Fourth Circuit again overturned Haden this time noting that Haden's decision was "overbroad" and overreached the case brought before him. For further information on this case, please see various articles from August 2001 through January 2003 in the Charleston Gazette and the Charleston Daily Mail as well as the following court opinions. First, see Haden's original decision of May 8, 2002, where he once again noted the illegality of valley fills under the CWA: Kentuckians for the Commonwealth $v$. Rivenburgh, 2002 U.S. Dist. Lexis 12048 (S.D. W. Va. 2002). Also, see the Fourth Circuit Court's overturn of Haden's decision: Kentuckians for the Commonwealth v. Rivenburgh, 317 F.3d 425 ( $4^{\text {th }}$ Cir. 2003).

${ }^{34}$ Lewis, Transforming the Appalachian Countryside, 115, 117. 
assumes that if the benefits of infringing on someone else's property rights outweighs the costs, then that use of the land was in the public's best interest and would, therefore, be allowed. ${ }^{35}$

It was these concepts of reasonable use and nuisance that the residents of Sylvester used in a lawsuit against Elk Run Coal, a Massey subsidiary. In September 2000, residents of Sylvester, West Virginia, complained to the West Virginia Division of Environmental Protection regarding the amount of coal dust that permeated their homes and businesses. This was one of numerous complaints that had been filed with the DEP from members of the community over a two-year stretch. West Virginia DEP issued citations in September and October 1998 and April and July 1999. Massey Energy subsidiary Elk Run Coal Company’s preparation plant spewed coal dust all over the town and failed to take proper precautions to contain the dust. A DEP inspector noted in his report that Elk Run was not running the coal dust sprayers on the stockpiles of coal, and that the coal dust was evident throughout the community on homes, cars, and sidewalks. In spite of this report, no citations were issued to Elk Run. According to the inspector, his superior told him not to issue citations, stating that the coal company could not be cited unless the inspector himself had actually seen the dust coming from the plant. The superior denied these claims and said that she merely needed some type of proof, such as videotape or “eyewitness accounts from mine inspectors." This, however, diverged from the agency’s previous practice of relying on the inspector's professional opinion. Hearings were heard through April 2000, and DEP hearing examiner George Warrick concluded that the company had created a "pattern of violations" regarding the coal dust; however, then-DEP director Michael Castle failed to act on the hearing examiner's recommendations to shut down the facility until the problem ceased, opting instead to vaguely order Elk Run to "make corrections to eliminate

\footnotetext{
${ }^{35}$ Ibid., 118.
} 
complaints about dust from residents." ${ }^{36}$ On October 25, 2000, the State Surface Mine Board ordered the plant closed until it fixed the dust problem plaguing the community. While Massey challenged the order, arguing that the DEP "could not prove the company caused dust problems," the company was denied and told that the subsidiary had "[no] right to damage communities.",37 Still experiencing problems with dust, in February 2001, 154 Sylvester residents, more than three-fourths of the town's citizens, filed a lawsuit in Boone County Circuit Court against Elk Run Coal and Massey Energy. Their lawsuit stated that not only could they no longer enjoy their hometown, but even food preparation for children at the local elementary school was being affected by the dust. Each morning, the cooks had to clean the coal dust from their cooking utensils, pots and pans before they could be used. The companies were also sued for the excessive light pollution and the incessant noise that accompanied their mining activities, including the lumbering trucks that paraded through town at all hours of the day and night. The suit asserted that the company had been unsuccessful in its attempt to control the dust, but that did not preclude the courts from stopping an otherwise unlawful activity. ${ }^{38}$ In April 2001, at a shareholder's meeting, Massey's CEO, Don Blankenship, stated that the coal dust came from the trucks not the preparation plants and that the company had done more than other companies in similar situations. ${ }^{39}$

\footnotetext{
${ }^{36}$ Ken Ward, Jr., "DEP Backs off Massey Dust Problems; Surface Mine Board to Hear Arguments this Week over Problems in Sylvester," Charleston Gazette, October 22, 2000.

${ }^{37}$ Ken Ward, Jr., "Massey Told to Fix Dust Problems," Charleston Gazette, October 26, 2004.

${ }^{38}$ Ken Ward, Jr., "Sylvester Residents Sue Massey Coal Subsidiary: Dust and Noise," Charleston Gazette, February 4, 2001; Ken Ward, Jr., "Massey Coal Dust Trial opens in Boone County," Charleston Gazette, December 13, 2002; Interview with Mary Miller; Interview with Pauline Canterberry.

For further information on the dusts' effects on the school, please see Chapter Three.

${ }^{39}$ Brian Bowling, "Massey President Blames Dust on Trucks, Not Plant," Charleston Daily Mail, April 18, 2001.
} 
In October 2001, Elk Run was once again cited by the DEP for the coal dust problems which still pervaded Sylvester. ${ }^{40}$ A November 21, 2001, Charleston Gazette editorial pointed out the long list of violations at the plant, the company's failure to fix the problems, and the new governor's (Bob Wise) promise to be stronger on environmental issues than his predecessor. The editorial concluded, "If Massey can't keep dust from raining down on the people of Sylvester, it should not be allowed to operate Elk Run." ${ }^{, 41}$ This was exactly the point the citizen's lawsuit was striving to make. A reprieve to the community was granted in late November 2001 when the DEP ordered Elk Run to "eliminate, move or cover the coal stockpile" that was raining coal dust on the community. ${ }^{42}$ The company was told that the next result would be to close down the plant entirely. ${ }^{43}$ By mid-December 2001, the company proposed a nontraditional, novel approach to the problem. The company would erect a dome over the stockpile to safely contain the coal dust within and slated its completion for May $2002 .^{44}$

In March 2002, Elk Run was once again fined by DEP. ${ }^{45}$ In the midst of these problems with coal dust, Elk Run asked for permits to increase the number of trucks going through the town. That request was denied, and DEP pointed out that increasing the truck traffic would also increase the continuing dust problems the town was experiencing. ${ }^{46}$ By the end of June 2002, the dome was nearly complete. Costing $\$ 1.5$ million and the largest of its kind, Sylvester's new

\footnotetext{
${ }^{40}$ Ken Ward, Jr., "Massey Cited Again for Dust in Sylvester," Charleston Gazette, November 18, 2001.

41 "Sylvester Rain of Dust Continues," Charleston Gazette, November 21, 2001.

${ }^{42}$ Brian Bowling, "Elk Run Ordered to Fix Dust Problem," Charleston Daily Mail, November 29, 2001.

${ }^{43}$ Ken Ward, Jr., "Massey Dust Order Repeated," Charleston Gazette, November 30, 2001.

${ }^{44}$ Ken Ward, Jr., "State Wants Dome Details; Massey Proposal has Friday Deadline," Charleston Gazette, December 18, 2001; Ken Ward, Jr., "Coal 'Dome' Finished by May, Massey Says," Charleston Gazette, December

45،"DEP Issues Citation Against Massey Subsidiary Elk Run Coal," Associated Press, March 3, 2002.

46 "Boone County Mine Denied Permit for Increased Truck Traffic," Associated Press, April 23, 2002; Paul Nyden, “DEP Denies Massey's Permit Request,” Charleston Gazette, April 29, 2002.
} 22, 2001. 
neighbor was supposed to solve the coal dust problems of the community. ${ }^{47}$ In July 2002 , Massey stated they were moving some of their production to Kentucky for the good of their stockholders. CEO Don Blankenship stated that it was becoming too expensive to invest in West Virginia. ${ }^{48}$ That same month, Massey faced another public relations disaster when a sediment pond over the town of Lyburn, Logan County, overflowed and flooded the town below, spilling slurry into a stream and onto residents' property. Massey was quick to assist in the clean-up, including putting residents up in hotels and replacing destroyed cars and even some homes. ${ }^{49}$

As the Sylvester trial approached, Massey lawyers attempted to have past violations kept out of the court record, a request that was granted on December 10, 2002, and a citizens' plea to the West Virginia Supreme Court of Appeals to intervene and permit the jury to hear about the violations was denied. ${ }^{50}$ Nearly two years after filing the lawsuit, the trial finally commenced on December 12, 2002. ${ }^{51}$ The time spent waiting allowed the residents of the town to collect even more evidence against Elk Run, including videos which clearly showed coal dust raining down on the town and coming from the plant. Along with the dust that came directly from the plant, the plaintiffs showed that the numerous overweight trucks (only 0.1 percent were at or below the legal weight limit) also added to the town's dust frustrations. ${ }^{52}$ In January 2003, a Boone County jury was told how the pollution from the plant had led to a decrease of nearly $\$ 4$ million in property taxes. An appraiser testified that coal dust resulting from the plant had decreased

${ }^{47}$ Brian Bowling, "Sylvester's Dust Getting Covered: \$1.5 million Dome Latest Effort to Comply with State," Charleston Daily Mail, June 25, 2002.

${ }^{48}$ Paul Nyden, "Massey CEO Says Company Looking to Ky," Charleston Gazette, July 20, 2002.

${ }^{49}$ Gavin McCormick, "Massey Pays Flood Bill: Logan Residents Receive Cars, New Homes," Charleston Gazette, August 13, 2002.

${ }^{50}$ Ken Ward, Jr., "Massey Wants Violations Kept Out of Trial," Charleston Gazette, November 23, 2002; Ken Ward, Jr., "Jury Won't See Massey Violations; Judge Rules on Evidence in Sylvester Dust Suit," Charleston Gazette, December 11, 2002; Brian Bowling, "Fines Don't Point to Fault, Lawyer Says; Attorney Claims Overeager Officials are to Blame," Charleston Daily Mail, December 11, 2002; "Supreme Court Won't Intervene in Coal Pollution Trial," Associated Press, December 19, 2002. 2002.

${ }^{51}$ Ken Ward, Jr., "Massey Coal Dust Trial Opens in Boone County," Charleston Gazette, December 13,

${ }^{52}$ Ken Ward, Jr., “Most Elk Run Trucks Overweight, Jury Told,” Charleston Gazette, December 19, 2002. 
property values in the community by 80 percent. The appraiser testified that many families had invested their entire life savings into their homes only to see the property sharply lose its value and are now unable to sell. Far from being soft for the plaintiffs, the appraiser had previously worked for banks, coal companies and the law firm representing Massey. Her company is the largest appraising company in southern West Virginia. ${ }^{53}$

For its part, Massey admitted the operation had caused some problems, and detailed for the jury the steps they had taken to alleviate the problems. Steps, the plaintiffs' lawyers pointed out, that did not work. ${ }^{54}$ Nearly two years after the lawsuit was filed, the plaintiffs won their case on February 7, 2003. The company was ordered to pay " $\$ 473,000$ in economic damages caused by coal dust falling on nearby homes, vehicles and other property." The court also ordered the number of coal trucks traveling through the town be reduced from 35,000 to 7,000 annually. ${ }^{55}$ No appeal was made of the decision. While appearing to bring some reprieve to the residents, the dome continued to have problems tearing, and while not as bad as before the court decision the community continues to experience dust problems. ${ }^{56}$

In November 2000, the West Virginia Highlands Conservancy and Trial Lawyers for Public Justice brought a lawsuit against the Department of the Interior (naming Gale Norton, head of the department), the Office of Surface Mining (particularly, Glenda Owens, the director), and Michael Callaghan (then director of the West Virginia DEP). This case also would be heard by Judge Charles Haden, II. At issue was the way in which WVDEP handled its regulatory

\footnotetext{
${ }^{53}$ Ken Ward, Jr., "Massey Costs Town \$4 Million in Property Value, Jury Hears," Charleston Gazette, January 25, 2003.

${ }^{54}$ Brian Bowling, "Massey Subsidiary Begins Defense in Coal Dust Case," Charleston Daily Mail, January 31, 2003; Ken Ward, Jr., "Massey Energy Starts Defense in Sylvester Dust Court Case," Charleston Gazette, January 31, 2003.

${ }^{55}$ Martha Bryson Hodel, “Jury Finds Massey Subsidiary Liable in Coal Dust Case," Associated Press, February 7, 2003; also see Ralph Anderson, et al v. Elk Run Coal Company, Inc., 2003 Cir. Ct of Boone County, West Virginia (April 8, 2003).

${ }_{56}$ Please see Chapter Four for further discussion of the continuing dust problems in Sylvester.
} 
duties under SMCRA, specifically the way it issued reclamation bonds for surface mined lands. The lawsuit sought to have these deficiencies fixed, or to have federal regulators take over the program. $^{57}$

Under SMCRA, bonds must be sufficient to reclaim a site should it be abandoned. Plaintiffs contended that the West Virginia bonding system systematically received far less in bonding monies than was necessitated for adequate reclamation and proceeded to outline how these bond amounts were inadequate to fix the problems that occurred as a result of surface mining. The Office of Surface Mining had repeatedly found the West Virginia bonding system "incapable of meeting the federal requirements." Furthermore, OSM had found that the liabilities of West Virginia's bonding system greatly exceeded its assets. Based on June 1994 estimates, those excess liabilities amounted to $\$ 22.2$ million, a conservative estimate that did not take into account the cost of treating polluted water discharged from bond forfeiture sites. The court noted that West Virginia's system failed in being as strong or stronger than the federal law and, therefore, the federal law superseded West Virginia's. ${ }^{58}$ While the court dismissed charges against Callaghan in May 2001 (under the Eleventh Amendment), it found that the federal defendants had not been living up to their responsibilities. ${ }^{59}$ The court observed that OSM had been "derelict and dilatory in the extreme" in their duties for better than a decade, but were now making attempts to correct those derelictions of duties, "clearly in response" of the lawsuit. ${ }^{60}$ In

\footnotetext{
${ }^{57}$ Trial Lawyers for Public Justice, press release, "Citizens' Group and TLPJ Sue Federal and State Regulators to Fix West Virginia's Coal Mining Program," November 14, 2000, available from http://www.tlpj.org/pr/wv_coal.htm, October 3, 2004; West Virginia Highlands Conservancy v. Norton, 2001 U.S. Dist. Lexis 4441 (S.D. W. Va. 2001).

${ }^{58}$ West Virginia Highlands Conservancy v. Norton, 2001 U.S. Dist. Lexis 4441 (S.D. W. Va. 2001).

${ }^{59}$ Ibid.; West Virginia Highlands Conservancy v. Norton, 2001 U.S. Dist. Lexis 7038 (S.D. W. Va. 2001); West Virginia Highlands Conservancy v. Norton, 2001 U.S. Dist. Lexis 13574 (S.D. W. Va. 2001).

${ }^{60}$ West Virginia Highlands Conservancy v. Norton, 2002 U.S. Dist. Lexis 4597 (S.D. W. Va. 2002). Note that by this time, Owens had stepped down in her role as director of the Office of Surface Mining and was replaced by Jeffrey Jarrett, whose name now appeared in the court case in place of Owens'.
} 
January 2003, while registering a proposal to set aside "federal approval of the state's plan to correct these defects," the court retained jurisdiction to ensure that the plan was enforced. ${ }^{61}$

Although the following case occurred just outside the nine coal counties referred to in this study, it may, nonetheless, prove extremely important in future MTR cases over conflicts between companies and private citizens over property rights. In October 2002, a Lincoln County circuit judge ordered the Caudill family homeplace to be sold. Ark Land Company (a division of Arch Coal) had bought a majority portion of the land that stands in the way of the expansion of Arch's mammoth Hobet 21 MTR mine from Caudill family heirs. However, Ark Land was unable to convince six of the heirs to sell. This led to legal action that resulted in the land being sold for $\$ 500,000$ to Ark Land Co. at a January 2003 auction. The heirs appealed this judgment to the West Virginia Supreme Court of Appeals, and in May 2004, the court overturned the lower court's ruling on the grounds that "lower court was wrong to discount the family's 'sentimental or emotional interests' in the property in favor of the economic concerns of a coal operator." ${ }^{, 62}$ Even more striking, Justice Robin Davis, writing on behalf of the court, stated that Ark's argument that theirs was the better use for the land was "self-serving." Justice Davis went on to write,

"In most instances, when a commercial entity purchases property because it believes it can make money from a specific use of the property, that property will increase in value based upon the expectations of the commercial entity. This self-created enhancement in the value of property cannot be the determinative factor in forcing a pre-existing coowner to give up his/her rights in property. To have such a rule would permit commercial entities to always "evict" pre-existing co-owners, because a commercial entity's interest in property will invariably increase its value." 63

${ }^{61}$ West Virginia Highlands Conservancy v. Norton, 2003 U.S. Dist. Lexis 292 (S.D. W. Va. 2003); Trial Lawyers for Public Justice, press release.

${ }^{62}$ Ark Land Company v. Rhonda Gail Harper, Edward A. Caudill, Rose M. Thompson, Edith D. Kitchen, Therman R. Caudill, John A. Caudill, Jr., Tammy Willis, and Lucille M. Miller, 2004 W.Va. Lexis 24 (W. Va. Sup. Ct. 2004); Ken Ward, Jr., "Court Blocks Forced Sale of Lincoln Family's Land," Charleston Gazette, May 8, 2004.

${ }_{63}$ Ark Land Company v. Rhonda Gail Harper, 2004. 
Ark's lawyers had argued that the company's plans for expansion of a mountaintop removal site was "the highest and best use of the property." To this Justice Warren McGraw queried whether "The highest and best use of the land is dumping?" Ark's lawyer replied that "it has become that....[T]hat's the reality. The use of land changes over time. The value of land changes over time." ${ }^{64}$ Ark's lawyer also argued that if the ruling went against his client, his client stood to lose a lot of money since they had already purchased land from other Caudill family heirs. In response to that argument, Justice Larry Starcher stated, "You made a business deal in anticipation of prevailing in this case. And if you don't prevail, you just made a bad business deal." ${ }^{, 65}$ Justice Davis reiterated this opinion in the Court's judgment, writing that:

"Ark Land voluntarily took an economical gamble that it would be able to get all of the Caudill family members to sell their interests in the property. Ark Land's gamble failed. The Caudill heirs refused to sell their interests. The fact that Ark Land miscalculated on its ability to acquire outright all interests in the property cannot form the basis for depriving the Caudill heirs of their emotional interests in maintaining their ancestral family home. The additional cost to Ark Land that will result from a partitioning in kind simply does not impose the type of injurious inconvenience that would justify stripping the Caudill heirs of the emotional interest they have in preserving their ancestral family home." 66

The fact that the Caudill heirs triumphed in this lawsuit is a very significant development. It indicated that the rights of private citizens' personal attachment to the land is as valid as the "economic, industrial" uses of industry. If coal companies had triumphed it would have continued a legal legacy of industry enjoying more rights to their land than private property owners had to their respective property. Moreover, the case indicated that when the two come into conflict emotional ties to the land must not be dismissed for merely monetary

\footnotetext{
${ }^{64}$ Ken Ward, Jr., "Forced Land Sale for Mine Debated in Supreme Court," Charleston Gazette, April 1, 2004.

${ }^{65}$ Ibid.

${ }^{66}$ Ark Land Company v. Rhonda Gail Harper, 2004.
} 
considerations. This may also prove helpful in maintaining the land in its original state rather than dismantling it for industrial use. Land still preserved, usable and lush, is more likely to attract outside business interests in the future than barren moonscapes that can neither grow nor maintain vegetation, or which has no forest covering left to assist in the all important matter of maintaining flood waters.

In July 2001, southern West Virginia was hit with one of the most devastating floods ever experienced. More than $\$ 150$ million dollars in damage occurred as a result of the raging waters which left more than a thousand people displaced and one person dead. ${ }^{67}$ The role of timbering and coal mining, particularly MTR mining, in those floods soon became the focus of no less than seven state lawsuits. Most of the lawsuits were combined into a single case that the State Supreme Court constructed a special "flood litigation panel" to hear various arguments before the case came to trial. Companies must act with "reasonable caution" to protect the rights of others, so the plaintiffs must prove that the companies operated with a "reckless disregard" and caused the damages. To this end, the lawsuits claim that the timbering and surface mining was done in such a haphazard way that it "caused natural surface waters resulting from the rainfall ... to be diverted and delivered in an unnatural way and in incomprehensible amounts down the mountains, hills and valleys ... destroying the lives and property" of the people in the wake of the rushing waters. At issue was what, if any, responsibility do timber and mining companies have with regard to the flooding, and what financial culpability do the industries have because of their particular business practices. The plaintiffs looked at nuisance and property damage laws as the basis for their lawsuit. In February 2004, the state supreme court agreed to address nine

${ }^{67}$ Randy Coleman, "State's \$43 Million May Not Be Enough for Flood Recovery," Charleston Gazette, August 10, 2001; Shirley Stewart, "What Caused the Flood to Be So Devastating?," Pineville (West Virginia) Independent Herald, July 18, 2001. While more than $\$ 150$ million in damages occurred, the state was responsible for a fraction of that, a little more than $\$ 43$ million. Still, of course, a significant amount of money for a cashstrapped state. 
complicated legal questions about nuisance law, reasonable use of water and property, and liability in flood-related cases. ${ }^{68}$

In August 2004, both sides were allowed to submit briefs regarding those questions. The plaintiffs' brief asserted that there exists precedence that nuisance is the responsibility -- and liability -- of the landowner. They further argued that "when an act of nature concurs with an act of man in causing nuisance, the human actor is responsible for the entirety of the harm." In other words, the debris from these sites that came crashing down on the plaintiffs was a direct result of mining and timbering practices and, therefore, those companies are responsible for the damage that debris caused. The plaintiffs also cited government studies that noted topographical disturbances of the magnitude in southern West Virginia caused a disturbance in the "rate of storm water discharge by as much as 59 percent." They also claimed that historical flood data showed "a direct correlation" between increased flooding and increased coal tonnage and board feet. ${ }^{69}$ For their part, the defendants argued that the plaintiffs wanted to discard other legal matters specifically for "nuisance" because they would then have to produce less evidence. ${ }^{70}$

Once the Supreme Court has addressed the nine specific questions, the parties will proceed with presenting their cases to the three-person panel. As of October 2004, no definitive decisions have been made regarding this case, and none seem forthcoming any time soon. How the court decides this case could prove very important to future southern West Virginia coalfield residents who experience personal property loss in flooding which can be proven to be directly linked to natural resource extraction.

${ }^{68}$ Ken Ward, Jr., "State Court to Hear Flood Case that Blames Mines, Timbering," Charleston Gazette, June 8, 2004.

${ }^{69}$ Flood Litigation, No. 31688, Plaintiff's Supplemental Brief, 2004 (W. Va. Sup. Ct. August 3, 2004) available from http://www.state.wv.us/wvsca/clerk/cases/FloodLitigation/31688PlaintiffSupp.pdf.

${ }^{70}$ Flood Litigation, No. 31688, Defendant's Supplemental Brief, 2004 (W. Va. Sup. Ct. August 2, 2004) available from: http://www.state.wv.us/wvsca/clerk/cases/FloodLitigation/31688DefendantSupp.pdf 
The onslaught of lawsuits over MTR illustrates that the residents of the affected communities are striving to protect their homes and land from what they believe to be an unreasonable infringement upon their rights. Through these legal struggles, the people most affected have striven to have their voices heard. Many plaintiffs in these cases had never encountered the legal system before signing on to a lawsuit to temper the mining practice that they see as negatively affecting them. While plaintiffs frequently have won in federal court, these decisions have been frequently overturned when appealed to the conservative Fourth Circuit Court. The companies have claimed the way they conduct business is necessary in order to conduct business for the economic sustainability of the communities most affected. Participants are vehement on both sides, and there does not appear to be any decline in citizeninitiated lawsuits.

\section{$\underline{\text { Conclusion }}$}

Lax enforcement of environmental rules and regulations have led to a series of lawsuits from private citizens and environmental organizations against regulators and coal companies. The increase in MTR operations has accompanied an increase in litigation. Since 1998, many lawsuits have challenged the legality of various aspects of mountaintop removal coal mining. As MTR proliferation continues, litigation regarding the practice and the nuisances it generates can be expected to continue and increase in spite of the enormous obstacles presented by a conservative Fourth Circuit Court and a presidential administration firmly aligned with industry interests. 


\section{Chapter Six \\ Show Me Where to Put My Fishing Pole: \\ Environmental Impact of Mountaintop Removal Surface Coal Mining}

Like a mountain mined for precious minerals, he is a man whose judgment is unsound. ${ }^{1}$

Ancient Sumerian Proverb

At the onset of the nineteenth century much of Appalachia had yet to be explored, and the forests were thick and dense. The massive industrialization that occurred in the region at the end of the century was accompanied with widespread environmental destruction. At the beginning of the twentieth century, two-thirds of West Virginia was covered by virgin forest; by 1920 it was gone, lost to untempered timbering. ${ }^{2}$ Particularly harmful was the industrial railroad logging that cleared out thousands of acres of forests. This timber boom lasted less than four decades, but the soil erosion, fires, and flooding that accompanied the boom resulted in massive environmental damage. ${ }^{3}$ The changes that came with this industrial growth did more damage to the mountains in thirty years than had occurred at anytime previously. ${ }^{4}$

In addition to the environmental destruction caused by timbering was that which was produced by the coal industry. The furor to develop West Virginia's coal resources left little room for concern of the environmental degradation that would follow. All forms of mining produce environmental impacts, and the acid mine drainage spewing from both underground and strip mines remains a persistent problem in many mining communities, particularly in the loss of aquatic life and drinkable water. When underground coal companies were finished with a seam, they would frequently pull up stakes, and abandoned coal tipples and machinery to rust. Strip

\footnotetext{
${ }^{1}$ Niek Veldhuis, "Sumerian Proverbs in their Curricular Context," Journal of the American Oriental Society 3 (2000): 120, 393.

${ }^{2}$ Lewis, Transforming the Appalachian Countryside, 5.

${ }^{3}$ Davis, Where There are Mountains: an Environmental History of the southern Appalachians (Athens, GA: University of Georgia Press, 2000), 166-169.

${ }^{4}$ Ibid., 212
} 
mining produced massive scars on the land, and reclamation provided only window dressing for the nutrient deficient land left behind. Only after state and federal laws were enacted to enforce regulations did the industry show concern for the environmental costs of their mining practices. ${ }^{5}$ This lack of respect for the environment has continued to the present day as massive MTR operations now pervade the southern West Virginia counties.

While mountaintop removal has been occurring in some form since the 1970s, its use grew in subsequent decades until by the first decade of the twenty-first century its magnitude had become a public concern. Between 1992 and 2002, 90,104 acres have been permitted for MTR in West Virginia. This includes 51,382 mining acres with 19,486 valley fill acres. The remaining 19,236 acres left include buildings and other infrastructure. ${ }^{6}$ Since the initial first MTR site, mountaintop removal mining permits have steadily increased in size. In fact, the granting of one permit could in essence change "thousands of acres of hardwood forests into grasslands." " In addition to the expansiveness of these permits, a 2003 review by the EPA found 150 valley fill violations in West Virginia wherein coal companies had been illegally dumping into valleys without the proper Clean Water Act permits. ${ }^{8}$ In this escalated version of strip mining, the tops of mountains are removed (sometimes in excess of 500 feet) to get to the underlying coal seams and the excess, or overburden, is pushed into the valleys and streams below. As a result of this mining practice, more than 500 miles of southern West Virginia streambed have been destroyed. The many environmental problems related to MTR are examined below and appear in categories and subcategories for easier access to the information.

\footnotetext{
${ }^{5}$ Geisler, Who Owns Appalachia?, 123.

${ }^{6}$ DEIS, Cumulative Impact Study, Appendix I, 45-46.

${ }^{7}$ Ken Ward, Jr., "Mountaintop Removal Could Devastate Region: Federal Study Paints Ugly Picture for Much of State," Charleston Gazette, May 5, 2002; DEIS, Chapter 3, Affected Environment and Consequences, IIIF.12, 102.

${ }^{8}$ Ken Ward, Jr., “EPA Review Finds 274 Valley Fill Violations,” Charleston Gazette, September 5, 2003.
} 


\section{Blasting}

As a more aggressive form of strip mining, MTR impacts the environment at every stage. During the exploration stage, boreholes are drilled or opened using explosives, and trenches and pits are dug. The most destructive exploration impact, however, come from the crude roads that are constructed to go to and from the site. These, too, can lead to erosion and can result in increased sediment loads in streams. ${ }^{9}$ Next is the extraction phase during which large blasts cause surface disturbances. Immense amounts of coal waste material are created and "the spread of chemically reactive particulate matter to the atmosphere and hydrosphere" takes place, negatively affecting air quality. ${ }^{10}$

\section{Watershed}

To competently understand the significance of the environmental degradation occurring in the southern coalfields, it is imperative to understand some basic concepts. First is a watershed, West Virginia Save Our Streams defines a watershed as being "an area of land that drains water, and everything in the water, to some sort of outlet."11 These watersheds are comprised of several small streams that feed into larger streams. In the forefront of the MTR dilemma, is what role, if any, headwater streams play in the overall water quality in West Virginia waterways. Healthy headwater streams assimilate nutrients and organic matter as well as provide habitat to many distinct and diverse organisms. ${ }^{12}$ To understand the crucial role of headwater streams in a watershed it is important to become familiar with the relatively simple concept of "stream ordering." First, picture a tree, the leaves are supported by twigs, the twigs

\footnotetext{
${ }^{9}$ Jeff Hansbarger, "Mountaintop Removal Mining: An Environmental Impact Assessment (EIA) Scoping Exercise and Impact Assessment of Mining Activities on Aquatic Resources" (MA thesis, West Virginia University, 2000), 45.

${ }^{10}$ Ibid., 45; for more information on the effects of blasting, see Chapter Three.

${ }^{11}$ West Virginia Department of Environmental Protection, West Virginia Save Our Streams Advanced Stream Assessment Manual (Charleston, WV: West Virginia Department of Environmental Protection, Division of Water and Waste Management, 2004), 3.

${ }^{12}$ Macroinvertebrate Bioassessment, 1.
} 
connected to small branches, and the small branches are connected to large branches, and the large branches are connected to the trunk. In trees, most life supporting energy is gained in the leaves, and is then transported to the larger branches and ultimately to the trunk. Stream ordering is much the same principle wherein headwater streams are the location where most energy needed for downstream life is acquired and then transported to the larger downstream reaches of a watershed. These headwater streams are considered to be $1^{\text {st }}$ order streams. When two $1^{\text {st }}$ order streams combine, a $2^{\text {nd }}$ order stream is formed. When two $2^{\text {nd }}$ order streams combine, a $3^{\text {rd }}$ order stream is formed and so on. ${ }^{13}$ See Figure 6.1.

\section{Figure 6.1}

Hierarchical Classifications of Streams By Stream Order

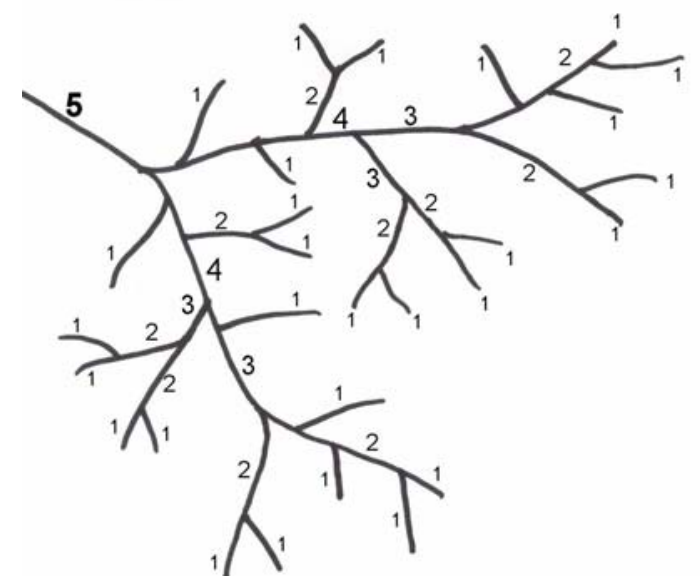

Source: Neil Payne and Fred Bryant, Techniques for Wildlife Habitat Management of Uplands, 1994.

\section{Chemical Factors and Sedimentation}

To adequately understand the health of a watershed, it is necessary to assess the health of the living communities in the watershed and these communities in response to human impacts. ${ }^{14}$ At the base of this assessment, the chemical factors involved must be examined. One of the most prominent factors is dissolved oxygen, the oxygen present in water. ${ }^{15}$ Since aquatic animals

${ }^{13}$ WV Save Our Streams, 3.

${ }^{14}$ Ibid., 3.

${ }^{15}$ Ibid., 16. 
depend on dissolved oxygen to live, and the amount of dissolved oxygen is dependent on water temperature, the amount of sediment and other factors, there is cause for concern in streams that experience sedimentation and thus reduced levels of dissolved oxygen. ${ }^{16}$ While sediment is a natural component of a stream, excessive sedimentation occurs by soil erosion in disturbed areas. ${ }^{17}$ Coal mining operations, particularly those using valley fills, contribute to increased sedimentation in surface water runoff. ${ }^{18}$ Sediment moves downstream in two ways: suspended load and bed load. ${ }^{19}$ Suspended sediment loads are suspended in the water column, and bed sediment loads are pushed along the bottom of the channel and are composed of coarser material such as sand and gravel. ${ }^{20}$ The increased sedimentation eliminates vital spawning habitat for many fish species and invertebrates by filling in gravel spaces in the streambed. ${ }^{21}$ This sedimentation can also destroy the deep pool habitats that provide vital cooler waters during summer months. ${ }^{22}$ Sediment loading in small streams is increased when an area is exposed to mining and logging. ${ }^{23}$ Strip mining higher slopes, such as the ones located in the southern coalfields of West Virginia, created a severe sedimentation problem. ${ }^{24}$ An April 2004 report by the National Institute for Chemical Studies included a measurement for water quality using the standards of the Clean Water Act as guidance. The study showed that one of the leading causes

\footnotetext{
${ }^{16}$ Ibid., 16.

${ }^{17}$ Ibid., 18.

${ }^{18}$ Macroinvertebrate Bioassessment, 25.

${ }^{19}$ WV Save Our Streams, 18.

${ }^{20}$ Ibid., 18.

21 Ibid., 18.

22 Jeffrey B. Wiley, Ronald D. Evaldi, James H. Eychaner, and Douglas B. Chambers, Reconnaissance of Stream Geomorphology, Low Streamflow, and Stream Temperature in the Mountaintop Coal-Mining Region, Southern West Virginia, 1999-2000 (Charleston, WV: U.S. Department of the Interior, U.S. Geological Survey, in cooperation with the West Virginia Department of Environmental Protection, Office of Mining and Reclamation, Water-Resources Investigations Report 01-4092, 2001), 3.

${ }^{23}$ Macroinvertebrate Bioassessment, 26.

${ }^{24}$ John Stacks, Stripping (San Francisco, CA: Sierra Club, 1972), 39.
} 
of "impairment to West Virginia's streams" was "excessive sediment." 25 Valley fills can result in sedimentation, mineralization, and acidification altering the water quality, limiting biodiversity and possibly causing extinction in some species. ${ }^{26}$ Large sediment loads can also eliminate habitat essential for survival during low-flows associated with normal summertime conditions. $^{27}$ The erosion that occurs, and leads to this increased sedimentation, also reduces the streamside vegetation that serve vital roles in creating habitat as well as aiding in the prevention of temperature fluctuations. ${ }^{28}$ The loss of this vegetation and the subsequent rise in water temperature also increases the metabolic rate of aquatic organisms as well as reduces the amount of dissolved oxygen in the water. ${ }^{29}$ When the water temperature reaches a certain point, and the dissolved oxygen is depleted, aquatic organisms are unable to exist. The streamside vegetation that has been lost due to the erosion that occurs because of sedimentation has also been shown to have a critical role in reducing the inflow of excessive nutrients, sediments, and contaminants into small streams. ${ }^{30}$ Excessive sedimentation leads to a drop in the productivity of the stream (i.e., "the nutrients and organisms produced by a stream"). The impact of this may be felt as certain organisms disappear from the equation, other higher organisms that prey on the now defunct organism may also be lost. A prime example of this is the Brook trout, a highly sought after sport fish, which has seen reduction in numbers as the lower organisms it feeds upon have been reduced by MTR. The reduction in the "prey species" could be accounted to fewer spawning habitats, "lethal levels of chemicals or acidity," and/or could be attributed to the

\footnotetext{
${ }^{25}$ Martha Bryson Hodel, "West Virginia Report Focuses on Environment," The Washington Post, April $22,2004$.

${ }^{26}$ Hansbarger, "Mountaintop Removal Mining: EIA," 49.

${ }^{27}$ WV Save Our Streams, 18.

${ }^{28}$ Ibid., 19.

${ }^{29}$ Ibid., 18-19.

${ }^{30}$ Macroinvertebrate Bioassessment, 26.
} 
changing of the actual habitat. ${ }^{31}$

\section{Erosion and Reclamation}

In 1972, a symposium was held in Charleston, West Virginia, to discuss the Stanford Report, a report commissioned by the West Virginia Legislature to compile information on the effect of surface mining on the environment, economy, and the legal and social health of the state. It was hoped that the report would gather enough information to conclude whether the West Virginia Surface Mining Reclamation Act of 1967 was effective. ${ }^{32}$ In his opening comments, Dr. Ralph Widener, moderator of the symposium, stated "most surface mining and environmental effects will be concentrated in the southern coalfields." 33 To further this argument, Dr. Robert Leo Smith, a Wildlife and Biology professor at West Virginia University, pointed to one of the survey areas, Bolt Mountain, Raleigh County, as an example of these problems. Smith testified that infrared photography illustrated that massively strip-mined land did not respond to revegetation, and that the area remained unhealthy. Smith further stated that "revegetation does not stabilize spoils and that instabilities are inherent in strip mining.",34 Revegetation preparation must be precise. Too much regrading will overcompact the spoil and will minimize planting success; if not packed enough the soil will erode. Without adequate spoil stabilization controlling runoff and erosion revegetation can not be successful. ${ }^{35}$ However, revegetating an area does not equal reclamation. Successful reclamation is impossible in the

\footnotetext{
${ }^{31}$ Hansbarger, "Mountaintop Removal Mining: EIA," 51; Jeffrey B. Wiley, et al., Reconnaissance of Stream Geomorphology, 2.

${ }^{32}$ Surface Mining in West Virginia: the Stanford Report in Perspective, Proceedings of a Symposium held February 26, 1972, Charleston Civic Center, Charleston, W. Va. (Charleston, WV: Mid-Appalachian Environmental Service, 1973), 1.

${ }^{33}$ Ibid., 3.

${ }^{34}$ Ibid., 7.

${ }^{35}$ Ibid., 8; Congress, House of Representatives, Committee on Government Operations, Environment, Energy, and Natural Resources Subcommittee, Strip Mining and the Flooding in Appalachia: Hearing Before a Subcommittee of the Committee on Government Operations, House of Representatives, $95^{\text {th }}$ Cong., 1 st sess., 26 July $1977,146$.
} 
southern coalfields because regulations do not necessitate stringent care of the area after the coal company has satisfied its bond. ${ }^{36}$ The study showed that the erosion rate of one acre of strip mine has the same rate as five acres of timbered forestland or ten acres of farmland. ${ }^{37}$ Another study of a partially stripped watershed showed an erosion rate of 5.9 tons/acre per year as opposed to 0.7 tons/acre per year on the unmined watershed. Furthermore, "97 percent of the erosion in the partially stripped watershed was attributed to the strip-mined area" even though the strip-mined area encompassed only 6.4 percent of the entire area. ${ }^{38}$ In a forward looking statement regarding the Stanford study, Dr. William Miernyk, a WVU economist, declared that if allowed to continue, the environmental damage of strip mining would be so dire that other economic development would not occur, and this future would be irreversible. He noted that surface mining has a limited life, either until all the coal is retrieved or until the legislature halts it, and with the economic and environmental health of the state at stake Miernyk supported the latter. ${ }^{39}$ Since the Stanford study, strip mining has only grown and expanded. Mountaintop removal surface coal mining had - and has - an even greater impact upon the environment, including soil erosion, than the traditional strip mine methods discussed in the Stanford Report. Strip mining, including MTR, still has its proponents and opponents with more at stake environmentally and, for the companies who have often spent millions of dollars for equipment readying an area for MTR, economically than ever before.

Reclamation of mine sites is the attempt to return the mined area to a useful purpose rather than leaving a barren shell that is often left after mining operations cease. Once all of the coal has been retrieved through mountaintop removal, reclamation must occur. If not

\footnotetext{
${ }^{36}$ Surface Mining in West Virginia, 8.

${ }^{37}$ Ibid., 10.

${ }^{38}$ Strip Mining and the Flooding in Appalachia, 147.

${ }^{39}$ Surface Mining in West Virginia, 25.
} 
implemented properly, it can negatively effect the environment through such things as soil erosion and "destabilization of mined lands. ${ }^{, 40}$ In 1971, a Mingo County Soil Conservation District Supervisor commented on the problems with replanting grass and seedlings on reclaimed strip mines. The growth of the planted vegetation was limited due to the lack of soil which he said was now located in the streams and riverbeds. ${ }^{41}$ A West Virginia University Extension Service study funded by Arch Coal, Inc., and the West Virginia Agricultural and Forestry Experiment Station, asserted that while the soil on MTR sites is different from the original soil, it shows signs of development as it ages, particularly on sites where grasses and other revegetation have occurred. ${ }^{42}$ While there is soil formation on these MTR sites, it is unknown how long it will take the soil to become similar to what it was before the mining took place, or if such a transformation will ever occur with the higher $\mathrm{pH}$ levels that are now present in the minesoils. ${ }^{43}$ In addition, planted trees must compete for nutrients with the grasses that were planted for quick covering, and results in slower regrowth of trees and woody plants. ${ }^{44}$ Vegetation rooting in these soils will have to be those that can withstand a higher $\mathrm{pH}$ level and, therefore, whatever regrows will certainly be different from what originally had been there. Opponents to mountaintop removal surface mining assert that no reclamation can put the land back to the way it was before MTR took place. While most supporters of MTR would not necessarily disagree with that assertion, some supporters, such as the Mineral Information Institute, go so far as to state that "reclaimed mine lands are usually more attractive to wildlife and human uses than before mining

\footnotetext{
${ }^{40}$ Hansbarger, "Mountaintop Removal Mining: EIA," 46.

${ }^{41}$ Montrie, "To Save the Land and People," 204.

${ }^{42}$ K.A. Thomas, Jeffrey Skousen, John Sencindiver, and Jim Gorman, Soil Horizon Development on a Mountaintop Surface Mine in Southern West Virginia (Morgantown WV: West Virginia University, Agriculture Extension, 2000), available from http://www.wvu.edu/ agexten/landrec/soilhori.htm.

${ }^{43}$ Mineral Information Institute, "Mine Reclamation: Coal \& Energy," available from http://www.mii.org/reclcoal.html, June 24, 2004.

${ }^{44}$ DEIS, Executive Summary, 3.
} 
started."45 Others have noted the benefits of increased wetlands and grasslands as well as commercial development. Arch Coal, Inc., has also been responsible for more than 200 acres of newly created wetlands on reclaimed sites. By contrast, the 2003 Draft Environmental Impact Statement of the Environmental Protection Agency (EPA) executive summary notes that the wetlands created, intentionally or unintentionally, are typically not of high quality. ${ }^{46}$ Still, the coal industry maintains “successful reclamation projects” to support its MTR practices.

Arch Coal, Inc., publicizes three particular reclamation projects. One, in conjunction with Premium Energy Corporation and Pocahontas Land Corporation, resulted in a premiere golf course dubbed the Twisted Gun golf course in Gilbert, Mingo County, West Virginia. Constructed on top of a reclaimed mountaintop removal site, the 18-hole course is the only one of its kind in a three county region (Mingo, McDowell and Logan Counties). ${ }^{47}$ Arch Coal, Inc. teamed up with the Mingo County Redevelopment Authority to create an Arctic Char fish hatchery, the only such hatchery of its type east of the Mississippi. ${ }^{48}$ In an alliance between southern West Virginia coal baron Buck Harless, Arch Coal, Inc., and the Mingo County Redevelopment Authority, a Wood Products Industrial Park was developed which, according to Arch's website, has "created 90 new jobs...with another 130 jobs anticipated."49 A Charleston Gazette story claimed that as many as 1,000 jobs may eventually be created as a result of this endeavor. ${ }^{50}$ Arch Coal, Inc., has also planted some 1.5 million trees on reclaimed sites and,

\footnotetext{
${ }^{45}$ Mineral Information Institute.

${ }^{46}$ DEIS, Executive Summary, 4.

${ }^{47}$ Further information on Twisted Gun can be found at http://www.twistedgungolf.com/

${ }^{48}$ Arch Coal, Inc., "Environment: Today's Energy is a Brighter Future," available from http://www.archcoal.com/environment/abrighterfuture.asp, June 30, 2004.

${ }^{49}$ Ibid.

${ }^{50}$ Michelle Saxton, "West Virginia Needs Balance, Governor Underwood says," Charleston Gazette, October 6, 2000.
} 
according to the Mineral Information Institute, some 80 percent of those survived. ${ }^{51}$ These statistics are suspect in light of the EPA's first formal draft EIS from January 2001 points out that "historically" such reclamation "has not been particularly successful.,"52 This is not to say that this percentage of tree survival is not possible if given the proper care, time, and resources spent for such an endeavor. It is, however, very uncharacteristic considering that such results rarely would occur on any given acre of reclaimed MTR land which generally receives only the minimum amount of care, time, and resources required by law to fulfill the reclamation bond. The language in the latter DEIS of 2003 had been slightly watered down and mentions efforts to "eliminate...barriers to establishing trees on reclaimed sites." 53 Some experts assert that the potential for productive forests exists on these sites if the proper measures are taken, such as constructing a soil medium from saving the weathered sandstone overburden materials and mixing in a minor amount of native topsoil to provide a source of native seeds. ${ }^{54}$ Such efforts require a stewardship, attention to detail, and an astute carefulness not typically associated with the beginning stages of MTR when the order of business is to quickly and economically remove the overburden for as quick and as easy access to the coal beneath as is possible. Arch Coal's Raleigh County subsidiary, Catenary Coal Company, has won acclaim for its reclamation of the Samples mine in Logan County. Massey Energy Company, in conjunction with Mingo County Redevelopment Authority is creating a dirt track on one of its former MTR sites. ${ }^{55}$ Both Arch Coal, Inc. and Massey Energy contributed money to purchase 800 acres of a reclaimed surface

\footnotetext{
${ }^{51}$ Mineral Information Institute, "Reclamation Success: Arch Coal, Inc.," available from http://www.mii.org/ArchTree/ArchTree.html, June 30, 2004.

${ }^{52}$ Ken Ward, Jr., "Mountaintop Removal Could Devastate Region," Charleston Gazette, May 5, 2002; First DEIS, Chapter Five, Environmental Consequences, sections 5-15, January 2001 (Washington, DC: United States Environmental Protection Agency), 34.

${ }^{53}$ DEIS, Chapter 3, Affected Environment and Consequences, III.B-12, 19.

${ }^{54}$ Ken Ward, Jr., "Arch Coal Strikes at Researcher," Charleston Gazette, May 30, 2004.

${ }^{55}$ A.T. Massey Energy information available from http://www.masseyenergyco.com, June 28, 2004.
} 
mine site to create the Earl Ray Tomblin Convention Center in Logan County. ${ }^{56}$ According to the National Mining Association, other uses of reclaimed mountaintop removal sites in West Virginia include shooting ranges, high schools, housing developments, athletic fields, an airport, an FBI complex, cemetery, and prisons. ${ }^{57}$

\section{Consequences of Valley Fills}

By covering hundreds of miles of streams, MTR valley fills destroy and alter stream ecosystems, which, undoubtedly, destroys countless undiscovered species along the way. This issue has not been lost on the experts. In April 2003, a group of eighty-five aquatic scientists from more than forty states submitted a letter to the United States Environmental Protection Agency (EPA) regarding proposed rule changes to the Clean Water Act. Particularly the Act's definition of "waters of the United States." The scientists point to the effects of "human activities" on the watershed and how this has resulted in the loss of small streams. They note how human activities create impervious surfaces. The proposed changes would have altered the rules to allow strip mining valley fills to cover intermittent streams. It is a continuous cycle wherein more strip mining leads to more intermittent streams which leads to more strip mining, leaving no outlet for the replenishment of the water supply. ${ }^{58}$ The scientists go on to state that “[E]lmination of small tributaries from Clean Water Act jurisdiction would lead to further loss and degradation of these [water] systems to the detriment of the physical, chemical, and biotic integrity of ecosystems downstream." ${ }^{, 59}$ The scientists end their letter with a strong conclusion which declares that, "The changes discussed in the proposed rulemaking and guidance document

\footnotetext{
${ }^{56}$ Logan County Chamber of Commerce, "Earl Ray Tomblin Convention Center," available from http://logancountychamberofcommerce.com/conventcenter.htm, June 28, 2004.

${ }^{57}$ National Mining Association, "Post-Mining Land Use," available from http://www.nma.org/policy/reclamation/land_use_article.asp, June 28, 2004.

${ }^{58}$ Aquatic Scientists to the U.S. Environmental Protection Agency, comments, on Docket ID OW-20020050, April 10 2003, 3. Comments concerned the Advanced Notice of Proposed Rulemaking (ANPRM) on the Clean Water Act Regulatory Definition of "Waters of the United States." Document in author's possession.

${ }^{59}$ Ibid., 4.
} 
will degrade rather than maintain and improve the quality of US waters. If our nation hopes to achieve the goals of the Clean Water Act, ephemeral, intermittent and small headwater streams should remain under its jurisdiction." 60

\section{Valley Fills: Spoil Material and Altered Stream Flows}

One of the biggest impacts, however, is the impact of the valley fills where the coal companies dispose of their excess spoil material. Valley fills can lead to the annihilation of hundreds of miles of streams and indirectly affect hundreds more. Proponents of MTR assert that the streams are not destroyed, but rather are rerouted under the rubble; however, when a stream loses form and function, then that stream ceases to exist. While asserting that these streams are still there, they can not tell interested parties where to put their fishing poles in the merely "rerouted" stream.

Some 724 miles of the DEIS study area waterways have been covered by valley fills from 1985 to 2001, and 1200 miles of headwater streams directly impacted by MTR via valley fills, roads, ponds and coal removal. ${ }^{61}$ An environmental impact assessment study of MTR on aquatic resources found that "[T] he covering of headwater perennial and intermittent streams on a large scale with spoil material is the major hydrological impact, and very characteristic of MTR. This is not a case of alteration, but of removal in function and form." ${ }^{92}$ Streams in valley filled areas flow throughout the year, including drought season where streams in unmined areas typically dry up during the drought season. Continuous streamflows may result in negative repercussions on invertebrate communities which are essentially the beginning of the nutrient cycle for downstream ecosystems. Even subtle alterations in streamflow can negatively impact these communities and have serious repercussions downstream. In fact, outflow from valley fills may

\footnotetext{
${ }^{60}$ Ibid., 9.

${ }^{61}$ DEIS, Executive Summary, 3-4.

${ }^{62}$ Hansbarger, "Mountaintop Removal Mining: EIA," 49.
} 
be detrimental because stream flows originating from valley fills may have higher "specific conductance" rates of dissolved metals in them which could be harmful to sensitive species and reduce the numbers of tolerant species. ${ }^{63}$

Land disturbances and the erosion associated with it typically increase subsequent specific conductivity. ${ }^{64}$ The mountainous topography in West Virginia does not lend itself to the formation of perennial streams, but rather hosts numerous intermittent streams resulting in small streams in each hollow. The increased strip mining of the few perennial streams have significantly decreased outflows due to the burial of the feeding intermittent streams. This can be compared to cutting off the roots of a plant. Without smaller roots, the larger roots cannot continue to function. And as with a plant, the loss of intermittent streams will cause the streams and rivers of Appalachia to die. In both 1999 and 2000, the Coal River in Boone County was added to the Nation's Most Endangered Rivers list by the American Rivers Association. In both years, the organization noted the devastation of fish, wildlife, streams, and forests as a result of MTR mining. The organization further observed that the effects of MTR are far reaching, effecting both environmental and cultural heritage. ${ }^{65}$ A 1997 ecological assessment of the Coal River watershed noted that the Coal River is one of the watersheds most affected by MTR, and the only one of the thirty-two watersheds studied in West Virginia that "produced no potential reference sites." Potential reference sites are characterized as being "high quality stream[s] with minimal human disturbances" that provide "significant and even irreplaceable wildlife habitat"

${ }^{63}$ Wiley, et al., Reconnaisance of Stream Geomorphology, 3.

${ }^{64}$ Macroinvertebrate Bioassessment, 25.

${ }^{65}$ American Rivers, press release, Coal River Listed Among Nation's Most Endangered Rivers, (Washington, DC: American Rivers, April 10, 2000), available from http://www.amrivers.org/index.php?module=HyperContent\&func=display\&cid=388, June 27, 2004. 
as well as being a "tremendous recreational resource." impaired by coal mining, and by other human impacts, such as sewage, that it was virtually impossible to find any area in the watershed that was not detrimentally impacted by human activity. $^{67}$

\section{Loss of Biodiversity}

The southeast is home to many rare invertebrate species that are found only in a few fragile locations "with pea-sized gravel or in springbrooks and seepage areas." For instance, sixty species of stoneflies from eastern North America exist only in these first and second order streams, or headwaters, and fully half of these sixty are "new to science in the last 25-30 years." 68 A 2000 study of the environmental impact of mountaintop removal mining on aquatic resources declared that MTR has a "profound" negative effect "on aquatic resources located within the watersheds of MTR areas." ${ }^{\prime 69}$ The study noted that the main problems stemmed from the "physical alteration of the aquatic resource, or even its complete removal."70 Water is removed from the streambed, rerouted through a culvert, and re-enters the streambed farther down the mountain. These simplified structures do not provide the capacity for biodiversity as is found in the unaltered channel. ${ }^{71}$ Thus, altering the environmental landscape. The DEIS stated the following:

"Even where inaccessible to fish, these small streams provide high levels of water quality and quantity, sediment control, nutrients and wood debris for downstream reaches of the watershed. Intermittent and ephemeral headwater streams are,

${ }^{66}$ Watershed Assessment Program, Division of Water Resources, West Virginia Department of Environmental Protection, An Ecological Assessment of the Coal River Watershed (Charleston, WV: WVDEP, Report number 05050009 - 1997, 1997), 55.

${ }^{67}$ Ibid., 55.

${ }^{68}$ DEIS, Chapter 3, Affected Environment and Consequences, III.D-3, 57.

${ }^{69}$ Hansbarger, "Mountaintop Removal Mining: EIA," 49.

${ }^{70}$ Ibid., 1.

${ }^{71}$ Aquatic Scientists, 3-4. 
therefore, often largely responsible for maintaining the quality of downstream riverine processes and habitat for considerable distances., ${ }^{, 72}$

In the last twenty years, more than 560 miles of Appalachian streams have been buried under valley fills, according to one investigator, and 350 square miles of forests might be destroyed "if no new limits are placed" on mountaintop removal coal mining. ${ }^{73}$ The number of Appalachian streams lost do not include ephemeral streams that flow sporadically because of rainfall or melting snow, or intermittent streams that flow only six months or less per year. Many of the streams in West Virginia are of this type. ${ }^{74}$ According to Dr. Ben Stout, a biology professor at Wheeling Jesuit University, these streams are as important or more important than perennial streams. ${ }^{75}$ These intermittent streams act as a connection between the forest and the river. Once filled in, that connection is gone. Not only is the connection gone, but in its place are poisons, such as aluminum, iron, and manganese, which are present in valley fill runoff. ${ }^{76}$

In their letter to the U.S. EPA, the aquatic scientists stated that "the increased frequency and intensity of flooding associated with replacement of small streams with impervious surfaces increases bank erosions, channel widening and incision and other changes in channel form." ${ }^{, 77}$ If the headwaters are channelized, piped, or filled, which occurs in mountaintop removal surface mining, ecosystems downstream can suffer as a result. The scientist emphasized that covering the stream valleys by valley fills has increased "fine particles in stream sediments," and has altered the flow and temperature downstream of the valley fills. ${ }^{78}$ This change can have an

${ }^{72}$ DEIS study, Chapter 3, Affected Environment and Consequences, III.C-1, 33.

${ }^{73}$ Ken Ward, Jr., "Endangered-Species Lawsuit could Target Mining," Charleston Gazette, March 3, 2003.

${ }_{75}^{74}$ Ken Ward, Jr., "Mining Fills are "Dumps" Biologist says," Charleston Gazette, June 22, 2002.

${ }^{75}$ Ted Williams, "Mountain Madness," Audubon Magazine, May/June 2001, available from http://magazine.audubon.org/incite/incite0105.html.

${ }^{76}$ Ibid.

${ }_{77}^{77}$ Aquatic Scientists, 4.

${ }^{78}$ Ibid., 4. 
impact on downstream population. ${ }^{79}$ Streams remaining in these watersheds where valley fills exist see an "increase of minerals in the water" and the macroinvertabates and fish that remain are not as diverse and are more "pollutant-tolerant" than what had been there. ${ }^{80}$ This effectively changes the composition of the species present. A 2001 Water Resources Investigation Report by the USGS in cooperation with the West Virginia Department of Environmental Protection, Office of Surface Mining, noted that temperature is an important factor for species viability because it controls the rate of growth of organisms and effects "life-cycle events," such as egg hatching, emergence and mating. Many aquatic insect taxa have adapted to the phenomena where streams dry up in the summer, and some have even adapted to an extent where the dry phase is critical in their reproduction. These insect taxa are adapted to resist desiccation by becoming dormant or by diapausing eggs, larvae, or pupae. ${ }^{81}$ This study sponsored by the U.S. Department of Interior takes a more positive tone than that of the aquatic scientists and other studies when it notes that streams at valley fill sites fluctuated less than at an unmined site. ${ }^{82}$ The 2003 DEIS stated, however, that this minimal fluctuation occurred during smaller storms, and actually reverses itself during larger rainfalls. ${ }^{83}$ In other words, any benefits seen during low intense rainfalls would be offset by the large amount of runoff that occur with larger, harder rainfalls, often resulting in flooding.

\section{Loss of Biodiversity: Role of Aquatic Insects}

Headwater streams contain a group of aquatic insects that break down nutrients to be absorbed by other organisms downstream, these three Orders of insects, Ephemeroptera, Plecoptera, and Trichoptera (EPT), are very useful in determining water quality in headwater

\footnotetext{
${ }^{79}$ DEIS, Chapter 3, Affected Environment and Consequences, III.D-14, 68.

${ }^{80}$ DEIS, Executive Summary, 4.

${ }^{81}$ Macroinvertebrate Bioassessment, p. 26.

${ }^{82}$ Wiley, et al. Reconnaissance of Stream Geomorphology, 3, 17.

${ }^{83}$ DEIS, Executive Summary, 4.
} 
streams and their presence indicates relatively healthy ecological conditions. ${ }^{84}$ The greater the number of EPT organisms, the better the quality of the water. As EPT species decrease and tolerant species replace them, this indicates that the water quality is decreasing. Leaf shredders are part of this EPT order. ${ }^{85}$ They play an important role in the ecosystem. Ninety percent of the annual energy input for headwater streams is attributed to leaf detritus (decomposed leaves that leaf shredders break down). If these leaf shredders cease to be, hence 90 percent of the energy input is gone, what are the downstream organisms going to survive on? ${ }^{86}$ In a workshop held in Sate College, Pennsylvania, in 1999, a group of experts discussed the value of headwater streams. Dr. Bruce Wallace, a professor of entomology and ecology, noted the importance of leaf shredders stating that it takes approximately 275 days for red maple leaves to breakdown when invertebrates are present. If most of these invertebrates are taken out of the equation, that time can increase to 575 days. He goes on to dispel the myth that destroying small portions of headwater streams does not threaten biodiversity. On the contrary, he states that the waters of Appalachia are rich with biodiversity and any tampering can threaten that biodiversity. He stresses the importance of these small headwater streams with a strong statement that destroying, essentially entombing, these important habitats is a very "dangerous" procedure for "life on this planet. ${ }^{87}$ During the same workshop, Dr. Bern Sweeney, Director and Curator of the Stroud Water Research Center in Avondale, Pennsylvania, noted that disturbing the "continuum of species" through the destruction of the headwaters or lower order of streams "greatly jeopardizes the ability of certain species to maintain local populations and provide propagules [a bud or

\footnotetext{
${ }^{84}$ Macroinvertebrate BioAsessment, p. 26

${ }^{85}$ Environmental Monitoring and Assessment Program, National Health and Environmental Effects Research Laboratory, Western Ecology Division, Office of Research and Development, EPA Mid-Atlantic Highlands Streams Assessment, Aquatic Insect Assemblages, EPA-903-R-00-015 (Corvalis, OR, Philadelphia, PA, Washington, DC: U.S. Environmental Protection Agency, August 2000), 12.

${ }^{86}$ DEIS, part 3, Affected Environment and Consequences, III.C-4, 36.

${ }^{87}$ US Fish \& Wildlife Service, The Value of Headwater Streams: Results of a Workshop, State College, Pennsylvania, April 13, 1999 (Washington, DC: US Fish \& Wildlife Service, April 2000), 16, $22-23$.
} 
shoot plants use to spread] for recolonizing disturbed areas" in the headwaters or the lower order of streams, can effect "up to 60 percent or more of the total food base of a small stream." 88 Samples from downstream of the mining shows decrease in the number of "sensitive organisms" present. ${ }^{89}$ A study of Arch Coal, Inc., mining confirmed this showing a decrease in EPT and an increase in tolerant organisms. ${ }^{90}$

According to a study sponsored by the Coal and Energy Research Bureau and the West Virginia State Legislature conducted by Dr. Kyle Hartman, a professor of Wildlife and Fisheries Resources at West Virginia University, "it is clear that valley fills have a negative effect on streams." Due "to the high diversity and faunal similarity to perennial streams, intermittent streams deserve adequate management or regulatory plans to protect species and their habitats." 91 Streams in valley filled areas exhibited lower numbers of sensitive aquatic insects that is typically reflective of an impaired system. The relevance of this is apparent when comparing non-impacted to impacted sites. ${ }^{92}$

\section{Effects on Wildlife: Bird Populations}

Changes of the physical landscape also produces shifts in the animal composition.

Mountaintop removal coal mining transforms mixed mesophytic forest land to grasslands. ${ }^{93}$

Grassland typically occurs in dryer areas whereas mesophytic forests occur in moist environments. There are some instances in which shrub habitats are created in southern West Virginia. Changes in the landscape due to MTR has resulted in a shift of bird distribution

\footnotetext{
${ }^{88}$ Ibid., 36-37.

${ }^{89}$ DEIS, Affected Environment and Consequences, III.D-9, 63.

${ }^{90}$ Ibid., III.D-14, 68.

${ }^{91}$ Macroinvertebrate Bioassement, 26.

${ }^{92}$ Kyle Hartman, Effects of Valley Fill Mining upon Aquatic Macroinvertebrate Communities in Southern
} West Virginia (West Virginia University: Morgantown, WV), available from http://www.forestry.caf.wvu.edu/programs/Wildlife\&fisheries/Research.htm, June 30, 2004; Macroinvertebrate Bioassessment, p. 29.

${ }^{93}$ Frank Ammer, "Population Level Dynamics of Grasshopper Sparrow Populations Breeding on Reclaimed Mountaintop Mines in West Virginia” (PhD diss., West Virginia University, 2003), 32. 
throughout southern West Virginia, increasing the edge and grassland bird species as well as a marked decrease of intact forest interior bird species native to the area. ${ }^{94}$ In addition to the obvious reasons of absence of intact forests leading to the decreased number of woodland communities, there are also other criteria as to why a decrease in these woodland animals has occurred while an increase in their typically mid-western counterparts has occurred. A 2001 study on raptors and red-shouldered hawks on reclaimed mountaintop removal sites again showed that mining was "shifting the species composition of raptors from a predominantly forested community to a grassland community." 95 Once again, the study showed a shift from the traditional woodland bird community to a grasslands bird community on reclaimed mountaintop removal mining sites. West Virginia is naturally home to an abundance of woodland bird species such as the Red-shouldered hawk and Broad-winged hawk; however, since the inception of MTR, the number of open-country species such as Northern Harriers and American Kestrels have increased. ${ }^{96}$ A 2003 study likewise showed an increase in grassland bird species such as Grasshopper Sparrows, Eastern Meadowlarks, Horned Larks, and Savannah Sparrows. It pays particular attention to the Grasshopper Sparrow saying that it outnumbered other species because it colonizes most suitable grassland habitats. ${ }^{97}$ Interior forest songbirds are absent from edge habitats in close proximity to mining sites because these species necessitate a large amount of forest to live in, and the birds are displaced from the MTR site as well as the edge forest near it. ${ }^{98}$

${ }^{94}$ DEIS, Chapter 3, Affected Environment and Consequences, III.F-7, 97.

${ }^{95}$ Melissa Balcerzak, "Raptor Abundance and Diversity and Red-shouldered Hawk (Buteo lineatus) Habitat Characteristics on Reclaimed Mountaintop Mines in Southern West Virginia," (MA thesis, West Virginia University, 2001), 12.

${ }_{96}$ Ibid., 28.

${ }^{97}$ Ammer, "Population Level Dynamics," 43.

${ }^{98}$ DEIS, Executive Summary, 3. 
While the population of grassland birds is declining throughout the United States, reclaimed MTR sites have seen an increase in these species. ${ }^{99}$ These birds are "rare" in West Virginia, but have seen an increase in their numbers as wooded lands are removed and grasslands take their place. Midwest grasslands are the main "breeding ranges" of many of these birds that are now finding suitable homes in southern West Virginia on reclaimed MTR sites. ${ }^{100}$ The DEIS observed that typical nesting habitats for grassland species included patches of dense grassland vegetation intermingled with areas of bare ground. ${ }^{101}$ These characteristics are contrary to the natural wooded forest that had once blanketed these areas. The population of quail and grouse are species which occupy open fields on reclaimed MTR sites. ${ }^{102}$ While the presence of these grassland birds may be good for their respective population, any increase in population is temporary due to forest succession at which time these species will be displaced from their newly acquired habitat when it is transformed from grassland habitat into a shrub-pole habitat. ${ }^{103}$

\section{Effects on Wildlife: Mammal Populations}

A 2002 study of small mammal communities on reclaimed mountaintop removal sites indicates that while small mammals continue to thrive on these reclaimed sites, they are largely from the Peromyscus family (i.e., types of mice that are habitat generalists or inhabit various habitats). ${ }^{104}$ These types of animals typically live in grassland habitats with little to no woodlands. ${ }^{105}$ Since raptors feed on mice, it is clear to see why the number of raptors associated with less wooded areas would now be increasing in West Virginia to feed on the mammals

${ }^{99}$ DEIS, Chapter 3, Affected Environment and Consequences, III.F-8, 98.

${ }^{100}$ Ibid., 98.

${ }^{101}$ Ibid., 98.

${ }^{102}$ Ibid., III.F-11, 101.

${ }^{103}$ Ammer, "Population Level Dynamics," 48.

${ }^{104}$ Douglass Chamblin, "Small Mammal Communities on a Reclaimed Mountaintop Mine/Valley Fill Landscape in Southern West Virginia" (MA thesis, West Virginia University, 2002), 40, 43.

${ }^{105}$ Ibid., 40. 
migrating into the newly formed grassland habitats, while the raptors associated with wooded areas are moving elsewhere to areas where they are better adapted.

Studies regarding the replanting on surface mine sites began as early as the 1940s. Early on, it was found that hardwoods failed to grow in the stripped land because of substantial damage to the trees due to rodents. ${ }^{106}$ Likewise, another study shows an increase in the rodent population on these mine sites. These areas are of an early successional forest habitat, meaning that they are at the first stage of development. They remain suspended in this stage for an extended amount of time because of the competition between the grasses and the trees for the reclaimed soil's nutrients. ${ }^{107}$ This is made even more difficult because of the poor quality, rocky soils present after reclamation. ${ }^{108}$ The competition that takes place is the biggest deterrent to regrowth. ${ }^{109}$ The higher number of mice may also negatively impact the growth potential of trees as the increased number of rodents on MTR sites have the potential to eat high numbers of the seedlings that are planted, thus decreasing the overall growth rate. A study on small mammal communities also observed that bog lemmings, masked shrews and house mice have increased on these reclaimed sites, all species that benefit from creation of grassland habitats. Other species such as white-tailed deer and wild turkey that can thrive in either grassland or wooded areas can be found along with the other primarily grassland species on MTR sites. ${ }^{110}$

\section{Effects on Wildlife: Forest Fragmentation}

Species that thrive in the native woodlands do not fair well on reclaimed MTR sites. EPA's DEIS study stated that deforestation and forest fragmentation, which resulted from MTR

\footnotetext{
${ }^{106}$ Jeff Skousen, Paul Ziemkiewicz, Christina Venable, Evaluation of Tree Growth on Surface Mined Lands in Southern West Virginia (Morgantown, WV: Agricultural \& Natural Resources Development, Extension service, 1998), 1. Originally in Green Lands, Winter 1998.

${ }^{107}$ Skousen, et al., Evaluation of Tree Growth, 12-13.

${ }_{108}$ Ammer, "Population Level Dynamics," 5.

${ }^{109}$ Skousen, et al., Evaluation of Tree Growth, 12-13.

${ }^{110}$ Chamblin, "Small Mammal Communities," 50.
} 
and valley fills, interrupt the Appalachian forests and is detrimental to forest-dwelling wildlife species. ${ }^{111}$ Eastern chipmunk, woodland jumping mice, woodland voles, and northern shorttailed shrew have seen decreased population numbers once wooded habitat was transformed into grasslands habitat. ${ }^{112}$ The absence of mature forests creates an environment where there is no longer a buffer to control temperature fluctuations. This means that temperatures can rapidly rise or fall according to the immediacy of the weather rather than intermittent fluctuations where species can acclimate at a steadier pace. ${ }^{113}$ Similar temperature fluctuations occur in arid regions where the weather will be scorching hot in the daytime and freezing cold after the sun goes down.

Amphibian and reptilian life is also affected by MTR. The southern Appalachians have one of the richest salamander faunas in the world. When these woodlands are converted to grasslands, however, the salamanders become far less common. Salamanders require loose soil with ample ground cover, and this environment is generally not found at reclaimed MTR sites. Salamanders are ecologically important to Eastern forests and their recovery at forest-disturbed areas is slow. The soil disturbance created by MTR is greater than typical forest clearing and may take an even longer amount of time for salamander recovery. ${ }^{114}$

There are other animals which are negatively impacted by MTR, most notably West Virginia's state animal the black bear. Mountaintop removal surface mining has displaced numerous black bears - and other animals -- from their native dwellings as humans encroach on the land traditionally inhabited by bears. These animals have evolved and adapted to survive in these particular areas. As the animals are forced from their habitats, they struggle to find new

${ }^{111}$ Ken Ward, Jr., "Mountaintop Removal Could Devastate Region,” Charleston Gazette, May 5, 2002; DEIS, Part 3, Affected Environment and Consequences, III-F.11, 101.

${ }^{112}$ Chamblin, "Small Mammal Communities," 50-51.

${ }^{113}$ Ibid., 51.

${ }^{114}$ DEIS, Part 3, Affected Environment and Consequences, III-F.9, 99. 
areas to live. This often leads to the now common occurrence of bears rummaging through garbage cans as they continually encroach upon areas inhabited by humans. This contact often leads to the bears' death. ${ }^{115}$

Another high profile animal affected by MTR is the wild boar. Its original habitat has been destroyed by MTR. Although a non-native species, it was introduced into the region by the West Virginia Division of Natural Resources (WVDNR). Like the black bear, the wild boar was regarded as a good choice for a big game animal. ${ }^{116}$

Tracking studies have shown that not only are these and other animals losing habitat in southern West Virginia, but they are also losing "traditional migration routes, travel corridors, and food sources." ${ }^{117}$ Mined land is not as productive as it was before its transformation, and the natural flora is not as pervasive. The forests which birds and smaller animals depend on for survival have been removed, and this also directly affects larger animals such as the black bear and wild boar which also rely on the forested areas for their survival. ${ }^{118}$ Birds that live within the forest interior, such as Acadian flycatcher, American redstart, hooded warbler, ovenbird, and scarlet tanager, are also negatively impacted by the loss or fragmentation of forest habitats to MTR. For an area to be considered to contain a minimal interior habitat, four major functions are required: (1) act as a link between headwater and low-order stream networks; (2) maintain unfragmented habitat for species that are wide-ranging or have a large home range; (3) maintain habitat for interior or remote species; (4) enhance habitat with natural disturbance regimes in

\footnotetext{
${ }^{115}$ Hansbarger, "Mountaintop Removal Mining: EIA," 52; Pauline Canterberry interview.

${ }^{116}$ Hansbarger, "Mountaintop Removal Mining: EIA," 51.

${ }^{117}$ Ibid., 52.

${ }^{118}$ Ibid., $52-53$.
} 
which most species evolve. ${ }^{119}$ As distance from an MTR site increases and forested lands become more plentiful, forest-interior bird species increase. ${ }^{120}$

In addition to how mining affects animals and flora, the forest itself is greatly altered by the mining practice of MTR. The DEIS cited a study that concluded approximately 244,000 acres of the southern coalfields area have been disturbed by past or current mining. ${ }^{121}$ Future MTR activities could potentially obliterate an area of Appalachian forest the size of Putnam County, West Virginia. ${ }^{122}$ Without more stringent MTR regulations, and adequate reclamation, future MTR will destroy nearly 230,000 acres of West Virginia land. ${ }^{123}$

\section{Slurry Impoundments}

The environmental impact of the disposal system associated with MTR is also expansive. Coal slurry impoundments are structures created for the disposal of coal waste. These impoundments are filled with highly toxic waste products that can seep into surrounding groundwater if proper precautions are not taken. Before being sent to market, the coal must be processed and cleaned. Each year between 350-400 million tons of coal go through processing using water, producing between 70-90 million tons of fine refuse slurry which is, for the most part, stored in coal waste impoundments. ${ }^{124}$ Impoundments include the embankment, basin, beach, pool, and slurry. ${ }^{125}$ Construction of coal slurry impoundments consists of two specific parts, an embankment and a basin. ${ }^{126}$ In Appalachia, the most common impoundment type is the

\footnotetext{
${ }^{119}$ Neil F. Payne and Fred C. Bryant, Techniques for Wildlife Habitat Management of Uplands (New York, NY: McGraw-Hill, 1994), 26.

${ }^{120}$ DEIS, Part 3, Affected Environment and Consequences, III-F.8, 98.

${ }^{121}$ DEIS, Part 3, Affected Environment and Consequences, III-F.12, 102.

${ }^{122}$ Ken Ward, Jr., "Mountaintop Removal Could Devastate Region," Charleston Gazette. May 5, 2002.

123 Ibid.

${ }^{124}$ National Academy of Sciences, National Research Council, Committee on Coal Waste Impoundments, Committee on Earth Resources, Board on Earth Sciences and Resources, Division on Earth and Life Studies, Coal Waste Impoundments: Risks, Responses, and Alternatives (Washington DC: National Academy Press, 2002 ), 24.

${ }^{125}$ Ibid., 215.

126 Ibid., 59.
} 
cross-valley impoundment where an embankment is built across a valley. The slurry is then discharged in the valley typically upstream of the embankment and then released into the basin along the embankment by pipeline system. ${ }^{127}$ The slurry must be actively monitored to ensure that it is not discharged into the surrounding areas. The impoundment itself is monitored to ensure its stability. Improper management of these impoundments, breaks in the stability, or lax enforcement of regulations can have devastating effects on the environment. The most famous and one of the most destructive of these breaks occurred on February 25, 1972, in Buffalo Creek, West Virginia, where an unstable dam broke, crashing down on the valley of Buffalo Creek and bringing with it more than 130 million gallons of coal slurry. The small community was left flattened and shattered in less than three minutes. The break resulted in the death of 125 people, more than 1100 injuries and left 4000 people homeless. ${ }^{128}$ After Buffalo Creek, it would be logical to assume that such impoundments would be made illegal. They were not. At present, more than 100 such impoundments exist all over West Virginia.

While other spills witnessed no loss in human life, the environment has not fared so well. Since the Buffalo Creek Disaster, thirty-two other spills have occurred in West Virginia with twenty (or 62.5 percent) of those occurring from 2000 to $2004 .{ }^{129}$ This increase may be attributed to the aging of the impoundments, more accurate reporting of spills, or quite possibly the increase in number of stripping operations and waste impoundments. Whatever the reason, since 1972, eighty documented miles of West Virginia streams have been affected by slurry spills, and 478,370,700 gallons of slurry are documented as having been released in these spills.

${ }^{127}$ Ibid., 67.

${ }^{128}$ Jack McCarthy, "A Man-made Disaster: Twenty-five Years Ago, a Dam Washed Away the Lives of 125 People," Charleston Gazette, February 23, 1997.

${ }^{129}$ Mine Impoundment Project, Mine Impoundment Location and Warning System (Wheeling, WV: Robert C. Byrd National Technology Transfer Center \& Wheeling Jesuit Center, 2004), available from http://www.coalimpoundment.com/spill/spillList.asp, June 14, 2004. 
Most of the West Virginia spills occurred in the southern West Virginia coalfields. ${ }^{130}$ The U.S. Code of Federal Regulations states only that an impoundment will have "an elevation of 5 feet or more above the upstream toe of the structure and can have a storage volume of 20 acre feet or more."131 The West Virginia code increases the height level to twenty-five feet and mandates a storage volume of at least fifteen acre feet or more. ${ }^{132}$ As long as the impoundment is built to code, it can be as large as the company wants it to be. West Virginia codes detail everything from filing for construction of an impoundment to and emergency planning. ${ }^{133}$ Presently, A.T. Massey subsidiary Marfork Coal Company in Raleigh County, has an impoundment with a height in excess 900 feet. That is more than two hundred feet higher than the Hoover Dam. ${ }^{134}$ Once completely filled, it will contain 8.1 billion gallons of slurry. This is up from the previous 5 billion gallons of slurry it had been permitted to encase. The Brushy Fork impoundment will be the largest impoundment of its kind. The impoundment rests on top of an abandoned underground mine. ${ }^{135}$ In addition to its immense size, the impoundment also contains mercury and other coal toxins. As this impoundment discharges into nearby streams, there is the risk of water contamination. When hydro-geologist Rick Eades surveyed the impoundment, he found that there had already been black water releases from the impoundment and that Massey had been sited for those releases as well as for numerous permit violations. He could find no proof

\footnotetext{
${ }^{130}$ Ibid., Number derived from adding up all of the "stream miles effected" aspects of information from $1972-2004$ as well as the spill information available from http://www.coalimpoundment.com/spill/discharges.asp?type=by_county, June 14, 2004.

${ }^{131}$ Department of Labor, 2003, "Water, sediment, or slurry impoundments and impounding structures," Code of Federal Regulations Title 30, part 77.216.

${ }^{132}$ Department of Environmental Protection, Division of Mining and Reclamation, "Series 4, Coal Related Dam Safety Rule,” West Virginia Code of State Rules Title 4, sec. 38, especially §38-4-2.7.

133 Ibid.

${ }^{134}$ Martha Bryson Hodel, "Massey Stockholders Reject Executive Bonus Proposal," The Charlotte (North Carolina) Observer, May 18, 2004.

${ }^{135}$ Phillip Babich, "Dirty Business,” November 13, 2003, available from http:/www.salon.com/tech/feature/2003/11/13/slurry_coverup/index_np.html; "UMWA Launches Community Education Campaign about Massey’s Brushy Fork Impoundment," United Mine Workers Journal (JanuaryFebruary 2004).
} 
that the "natural fractures in the interburden" (everything between the impoundment and the underground mine that it sets over) had ever been studied for their risk factor. ${ }^{136}$ Brushy Fork is classified as a Type $\mathrm{C}$ dam which essentially means that if it breaks, it is expected to cost human life in addition to causing substantial damage to industry, commercial buildings, homes, key public utilities, and frequently used roads. ${ }^{137}$ Brushy Fork is one example of numerous coal impoundments throughout the state, mainly in the southern coalfields. See Appendix 2 for a list of coal impoundments found in the nine southern coalfield counties. Appendix 3 lists coal spill information for the nine counties.

\section{Flooding}

In July 2001, after suffering a devastating flood in May of the same year, southern West Virginia was hit with heavy torrents of rainfall and more massive flooding. Contemporary accounts of the flooding had reported the rainfall as heavy as ten inches in Wyoming County, the hardest hit county in southern West Virginia. ${ }^{138}$ In actuality, Wyoming County received between 1.53 and 5.32 inches of rainfall. Mullens, the hardest hit community in Wyoming County, received the high of 5.32 inches of rainfall. ${ }^{139}$ Earlier accounts had listed Mullens rainfall as 10 inches or more. Like most communities in the southern West Virginia county, Mullens is surrounded by both timbering and strip mining operations. Having endured a flood not quite two months earlier, the already saturated ground mixed with the rainfall caused severe flooding. Of course, receiving more rain in one day than the county typically receives in the entire month of July leaves no question that there would have been flooding; however, the question as to what

\footnotetext{
${ }^{136}$ Rick Eades, Brushy Fork Slurry Impoundment - A Preliminary Report (Huntington, WV: Ohio Valley Environmental Coalition, 2000), 3-4; UMWA Journal (January-February 2004).

${ }^{137}$ Department of Environmental Protection, Division of Mining and Reclamation, "Series 4, Coal Related Dam Safety Rule,” West Virginia Code of State Rules Title 4, Sec. 38, especially §3.4.b.3. 2001.

${ }^{138}$ Ken Ward, Jr., "Devastating Flood Could Have Been Much Worse,"Charleston Gazette-Mail, August 5,

${ }^{139}$ Flood Advisory Technical Task Force, Runoff Analyses of Seng, Scrabble, and Sycamore Creeks, part one (Charleston, WV: Division of Environmental Protection, 2002), 75.
} 
extent the flooding would have been without the effects of strip mining begs for an answer. As the 2002 DEP study concluded, there was certainly an effect on flooding due to the disturbance of the land by surface mining. ${ }^{140}$ However, the same area had endured more rainfall during the flood of 1977 when some areas of southwestern West Virginia endured 15.5 inches of rainfall. ${ }^{141}$ While a major flooding did occur, it did not cause nearly the damage to the area that the July 2001 flood left in its wake.

As MTR disturbs massive amounts of cover, the runoff results in higher levels of flooding for areas affected by surface mining. ${ }^{142}$ A 2002 West Virginia Division of Environmental Protection study concluded that surface mining does in fact increase the volume and velocity of runoff in the watershed. ${ }^{143}$ Along with runoff, there is increased erosion that fills up the water channel. The resulting siltation (accumalation of silt at the bottom of a streambed) diminishes the draining capacity of streams. Loss of soil through the disturbance of "overburden" deposits high levels of sediment into the watershed as the vegetative cover that once helped stabilize the soil is no longer there. Mining on steep slopes may hasten erosion or even block entire stream channels by causing landslides. ${ }^{144}$ In turn, the water that would normally run into the channel is now forced to flow out onto the streambanks where it picks up debris and further obstructs the flow of water. Only a small percentage of vegetation is capable of growing on a reclaimed strip-mined area, and there is little chance of the scant vegetation having the ability to hold back sufficient runoff. This means that even a very small amount of rainfall can create a potential for floods in low lying areas. In other words, in strip mined areas,

${ }^{140}$ Ibid., 2, 75

${ }^{141}$ U.S. Geological Survey Water Resources in Kansas, Summary of Significant Floods, 1970 Through 1989, by Year, available from http://ks.water.usgs.gov/Kansas/pubs/reports/wsp.2502.sum77.html, June 22, 2004.

${ }^{142}$ Alan Randall, Estimating Environmental Damages from Surface Mining of Coal in Appalachia: a Case Study (Cincinnati: Industrial Environmental Research Laboratory, Office of Research and Development, U.S. Environmental Protection Agency, 1978), 67.

${ }^{143}$ Flood Advisory, part one, 2.

${ }^{144}$ Randall, Estimating Environmental Damages, 67. 
the peak flow rates increase, sometimes by three to five times the usual flow rate amounts. The three to five time peak flow rate increase on surface mined sites means that 5 inches of rainfall could easily seem like, or have the same effect as, fifteen to twenty-five inches of rain. ${ }^{145}$ Peak flow rates were found to be directly correlated with the percent of surfaced mine areas. The more area that was surface mined, the greater the effect of the floodwaters. ${ }^{146}$ Headwater streams originate at higher elevations. The amount of time these headwater streams retain water is reduced in strip mined areas, thus increasing the amount of floodwaters that move downstream. On flat floodplains, even small increases in flood peak flows can increase the amount of area that are inundated. ${ }^{147}$

\section{Environmental Impact: Proponents and Opponents Views}

Despite all the promises of sound reclamation and minimal environmental impact, the reality is often quite different. Originally intended as only a variance in surface mining activities, MTR has flourished in the last decade and along with its increase numerous opponents have emerged to become outspoken critics of the practice. The coal industry has never sat silent against what they feel are attacks, and they have vigorously defended MTR, employing a large arsenal of weapons. One of them has been a systematic campaign of misinformation through multiple machines. Recently, the hi-tech medium of the internet has been used. One website is simply called "Mountaintop Mining." There is no indication on the site who is responsible for its content, but upon examination it is linked to "Mining USA" and then to Mining Internet Services, Inc. (MISI), which was "created solely to provide Internet services tailored to the

\footnotetext{
145 Ibid.

146 Ibid.

${ }^{147}$ Ibid., 68.
} 
mining community."148 The site claims that the amount of stream loss from MTR is minimal and that where most hollow fills are placed contain no streams. ${ }^{149}$ Adversely, the DEIS report found that more than 500 miles of West Virginia streams have been impacted as a direct result of MTR and valley fills. ${ }^{150}$ Other organizations place that amount to as much as 1000 or more miles of headwater streams covered by valley fills. ${ }^{151}$ The streams that are not buried may be compromised through pollution. ${ }^{152}$ Perhaps this loss is minimal to industry; however, any loss of stream can have dire consequences further downstream. In addition, the same DEIS study reported that if stricter regulation and better reclamation is not in place, MTR will destroy nearly 230,000 acres of "ecologically diverse hills and hollows." The DEIS goes on to caution that the changes incurred because of MTR may jeopardize the "biological integrity of the study area" even as it has already significantly altered the area's "landscape and terrestrial wildlife habitats." As the size of these operations increase, one permit may radically alter thousands of acres of forests leaving grasslands where once there were hardwood forests. ${ }^{153}$ The mountaintop mining site uses the familiar argument that the reclaimed MTR site leaves "flatter, more useful land," and that the mountains are not actually "flattened.",154

Some West Virginia politicians also make such claims. In fact, in 2002 the Cabinet Secretary of the West Virginia Division of Environmental Protection, while appearing in front of the United States Senate's Environment and Public Works Committee regarding proposed

\footnotetext{
${ }^{148}$ Mining Internet Services, Inc., "Who is MISI," available from, http://www.miningusa.com/misi/who_is_misi.htm June 26, 2004.

${ }^{149}$ Mining Internet Services, Inc., "Mountaintop Mining," available from, www.mountaintopmining.com, June 26, 2004.

${ }^{150}$ DEIS, Cumulative Impact Study, Appendix I , 49.

${ }^{151}$ Ohio Valley Environmental Coalition, flyer, "Mountaintop Removal Mining Fact Sheet," available from http://www.ohvec.org/issues/mountaintop_removal/articles/mtr_fact_sheet.pdf, July 9, 2004.

${ }^{152}$ Ken Ward, Jr., "Mountaintop Removal Could Devastate Region," Charleston Gazette, May 5, 2002.

${ }^{153}$ Ibid.; DEIS, Chapter 3, Affected Environment and Consequences, III.F-12, 102.

${ }^{154}$ Mining Internet Services, Inc. (Lexington, KY: Mining Internet Services, Inc.). Other information available from www.mountaintopmining.com, June 26, 2004.
} 
changes in the valley fill rules (that would have loosened the rules), stated that the mining created useful flat lands for various recreational and business opportunities. ${ }^{155}$ Overall, such arguments are false and do not hold up under close scrutiny. Only minimal economic development has occurred on any of these sites, but industry continues to "spew propaganda about the need for flat land as a panacea [with the] promise [of] a new era of coalfield economic prosperity." 156 The oldest such site in the state is in Fayette County. Cannelton Industries began mining Bullpush Mountain in 1970. Fayette has yet to benefit from its flatness, having never been developed and utilized in its "more useful" metamorphosis. ${ }^{157}$ The Mountaintop Mining website also infers that MTR was seen as a normal mode of surface mining when the 1977 SMCRA law was enacted. In fact, it was viewed as an occasional variance, and was not supposed to occur unless the company conducting MTR operations submitted plans to develop the flattened land. ${ }^{158}$ At the time of SMCRA's enactment, neither the framers of the act, nor anyone else, could have imagined the large draglines that were on the horizon that would make MTR as common a practice as it now is in the Appalachian mountains.

Another argument the Mountaintop Mining website and others make is that these sites create "more wildlife." While reclaimed sites have the potential to create different habitats from the original ones, the wildlife that had originally inhabited the now reclaimed sites face starvation and must move to a habitat for which they are adapted. They do not have the luxury

${ }^{155}$ U.S. Senate Committee on Environment \& Public Works, Senate Subcommittee on Clean Air, Hearing to review proposed revisions to the wetlands program of the Clean Water Act with respect to "fill material" and "discharge of fill material, statement of Michael Calaghan, Secretary, West Virginia Department of Environmental Protection, $107^{\text {th }}$ Cong., 2d sess., 6 June 2002, available from http://epw.senate.gov/107th/Callaghan_060602.htm, June 20, 2004. (2004), 75.

${ }^{156}$ McGinley, "From Pick and Shovel to Mountaintop Removal," Environmental Law Vol. 34, No. 1 August 9, 1998.

${ }^{157}$ Ken Ward, Jr., "Flattened: Most Mountaintop Mines Left as Pasture Land in State," Charleston Gazette,

${ }_{158}$ Surface Mining Control and Reclamation Act of 1977, U.S. Code, title 30, sec. 1265 (e)(2); Ken Ward, Jr., “Mountaintop Removal Could Devastate Region,” Charleston Gazette, May 5, 2002. 
of waiting for the soil to replenish and the vegetation to take root after massive MTR has occurred. Displaced animals are forced to encroach upon human habitat in search of food and shelter where they face death because of the danger in their close proximity to humans.

Residents of areas where MTR occurs give details of animals plundering their gardens and garbage cans. One such resident, Pauline Canterberry of Sylvester, Boone County, produced pictures of emaciated black bears rummaging through her garbage cans. She stated that this has become a more and more frequent occurrence as the MTR site near her home has expanded, forcing animals from their natural habitat. ${ }^{159}$ Several years ago, Arch Coal, Inc., produced a commercial which proclaimed, "Mountaintop removal. It's the right thing to do." Likewise, with regards to mountaintop removal, the "mountaintopmining.com" site stated, "It's simply the right thing to do- both for the environment and for the local economy. A true win-win."160 That assertion, on both levels, is highly contested and debatable.

\section{$\underline{\text { Conclusion }}$}

The environmental effects of strip mining have been a contentious issue for decades. Visible scars are left on the landscape and the environment and wildlife are also affected by strip mining methods. As a more extreme version of strip mining, MTR disturbs more land at a quicker rate than more traditional methods of strip mining. The effect this type of mining has on the environment is a very controversial issue. Much research has been conducted with regards to the effect that this mining has on the environment, including research funded by coal companies and coal-associated organizations. Study after study concluded that MTR takes forested woodlands and effectively transforms them into grasslands. While these new grasslands support

\footnotetext{
${ }^{159}$ Pauline Canterberry interview.

${ }^{160}$ Mining Internet Services, Inc. (Lexington, KY). Other information available at www.mountaintopmining.com, June 26, 2004.
} 
various wildlife and enjoy minimal revegetation successes, they represent an entire change from what had previously been on the unmined site. Some of the main problems associated with MTR include soil depletion, sedimentation, low success rate of tree regrowth, lack of successful revegetation, displacement of native wildlife, and burial of streams. These problems will only worsen as MTR acreage expands. 


\section{Epilogue: \\ Requiem for the Mountains?: \\ Southern West Virginia at a Crossroad}

"We shall achieve conservation when and only when the destructive use of land becomes unethical punishable by social ostracism."

Aldo Leopold

In 1970 the first mountaintop removal mine in West Virginia opened on Bullpush Mountain in Fayette County. It served as a small precursor to the massive mountaintop removal sites that would pervade the southern coalfield region in the 1990s to the present day. With the introduction of massive twenty-story draglines in the 1980s, coal operators seized the opportunity to extract a greater percentage of coal. With the passage of stricter emission standards to the Clean Air Act in 1990, West Virginia's southern West Virginia coal industry was ripe for another boom cycle. Rich in low sulfur, high-volatility coal, southern West Virginia once again became a prime source of fuel for the nation. The new standards, enacted to protect the environment by reducing toxic air emissions, acid rain, and urban air pollution, had the unexpected, ironic effect of decimating the southern West Virginia forest acres and streams by mountaintop removal mining.

Seeing a clear avenue to increase profits, large coal companies expanded their mountaintop removal operations to fulfill the increased demand for the low sulfur, high-volatility coal found within the southern coalfield region. Finding themselves in competition with western coal, the Appalachian coal operators increased the extraction of coal via MTR to secure the most coal the cheapest way to earn the greatest profits. The effects of this massive increase in MTR coal were immediate and profound in the southern West Virginia coalfields. Old arguments pitting the environment against employment in a region where unemployment is high have

\footnotetext{
${ }^{1}$ Aldo Leopold, "Wildlife in American Culture," Journal of Wildlife Management 7(1): 1-6.
} 
resulted in a clash between MTR employees, coal operators, and the UMWA on one side, and on the other residents negatively affected by MTR, environmentalists, and citizens concerned with the long-term impact of MTR.

Nearly ninety years ago, the federal government intervened to reforest West Virginia's mountains following industrialization because soil erosion and successive loss of stream flow that resulted from deforestation threatened important waterway transport systems. At that time, the government had an overt, vested interest in protecting West Virginia's waterways. ${ }^{2}$ Present day devastation occurring in the southern West Virginia coalfields is in dire need of a similar reprieve. A history of unresponsive, neglectful politicians, or politicians unwilling to confront King Coal, does not bode well for state intervention on behalf of either the coalfield communities, or those citizens most in need of assistance. At this writing, there is little chance for such a reprieve from a federal administration that has actively attempted to weaken environmental standards in favor of the coal industry at the expense of communities. Undeniably, MTR allows for the quickest, cheapest extraction of coal, but it also has resulted in the degradation and sometimes elimination of entire coal communities and the accompanying outmigration of thousands of residents. Considering the overall social and environmental costs, it is only cheap for the coal company.

Through less than two decades of significant activity, mountaintop removal coal mining has caused irreparable harm to the environment, people, social, and cultural heritage of an entire region. If companies continue to operate outside of the minimal laws enacted to protect the environment, if politicians continue to allow big coal interests ultimate power, and if mountaintop removal coal mining is allowed to continue unabated, then southern West Virginia coalfield communities will cease to exist in any true sense of the word. Ghost towns will spring

\footnotetext{
${ }^{2}$ Ronald Lewis, Transforming the Appalachian Countryside, 278.
} 
up throughout the region in barren lands reclaimed, if at all, to look like Midwestern grasslands while West Virginia's most viable renewable resource, hardwood timber, is effectively obliterated. The gently rolling mountains will be replaced by moonscapes and the wilderness will be gone. If MTR is not legally halted or diminished, southern West Virginia coalfield communities, the people and land, will be as gone as the last ton of coal scraped out of the mountains themselves. 


\section{Bibliography}

\section{Archival Records}

Strip-mining collection. Papers. West Virginia and Regional History Collection, A\&M 2618. West Virginia University, Morgantown, W.Va.

\section{Newspapers}

Charleston Gazette [Charleston, W.Va.]. 1978, 1985, 1989, 1994, 1995, 1997, 1998, 1999, 2000, 2001, 2002, 2003, 2004.

Charleston Daily Mail [Charleston, W.Va.]. 1997, 1998, 1999, 2000, 2001, 2002, 2003, 2004.

Charlotte Observer [Charlotte, N.C.]. 2004.

Herald-Dispatch [Huntington, W.Va.]. 2003.

Logan Banner [Logan, W.Va.]. 1999.

Dominion Post [Morgantown, W.Va.] 2003.

Independent Herald [Pineville, W.Va.]. 2001.

New York Times [New York, N.Y]. 1933, 1937, 1943, 1947, 1999.

Pittsburgh Post-Gazette [Pittsburgh, Penn.]. 2004.

Raleigh Register-Herald [Beckley, W.Va.]. 1998, 2002, 2004.

Washington Post [Washington, D.C.]. 1999, 2000, 2004.

\section{Trade and Professional Journals}

Coal Age. 1997-2003.

United Mine Workers of America Journal. 1997-2004.

\section{West Virginia Government Documents}

Consolidation Coal Company. Monitoring and Emergency Warning Plan and Procedures for the Joe Branch Coal Refuse Dam.Welch, WV: Department of Environmental Protection, Permit Section, Region IV, 2003. 
"Department of Environmental Protection Division of Mining and Reclamation Series 4 Coal Related Dam Safety Rule.” West Virginia Code of State Rules Title 4, Sec. 38.

Flood Advisory Technical Task Force. Runoff Analyses of Seng, Scrabble, and Sycamore Creeks. Charleston, WV: Division of Environmental Protection, 2002.

West Virginia Bureau of Employment Programs. Employment and Unemployment Data. Charleston, WV: Bureau of Employment Programs, Research, Information and Analysis, 2004.

West Virginia Department of Environmental Protection, Division of Water and Waste Management. West Virginia Save Our Streams Advanced Stream Assessment Manual. Charleston, WV: West Virginia Department of Environmental Protection, 2004.

West Virginia Department of Environmental Protection, Watershed Assessment Program Division of Water Resources. An Ecological Assessment of the Coal River Watershed. Report \#OSOS0009. Charleston, WV: West Virginia Department of Environmental Protection, 1997.

West Virginia Department of Tax and Revenue and West Virginia Development Office. Analysis and Recommendations for West Virginia Tax Incentives. Charleston, WV: Dept. of Tax and Revenue, 2002.

Musgrave, John C. Valuation of active and reserve coal property for Ad Valorem property tax purposes. Charleston, WV: West Virginia State Tax Department, 2004.

Tosun, Mehmet S. “A Comparative Assessment of West Virginia's State Tax System," Institute for Public Affairs. The West Virginia Public Affairs Reporter, Vol. 19, No. 3 Summer 2002.

\section{U.S. Federal Government Documents}

Appalachian Land Ownership Task Force. Land Ownership Patterns and Their Impacts on Appalachian Communities: A Survey of 80 Counties. Washington, DC: Appalachian Regional Commission, 1981.

Aquatic Scientists. Comments to the U.S. Environmental Protection Agency on Docket ID OW2002-0050 reg. the Advanced Notice of Proposed Rulemaking (ANPRM) on the Clean Water Act Regulatory Definition of "Waters of the United States." Washington, D.C.: U.S. Environmental Protection Agency, 2003.

Department of Energy, Energy Information Administration. Coal Industry Annual Report Data Table, 1995. Washington, DC: Department of Energy, 1995. 
Department of Energy, Energy Information Administration. Coal Industry Annual Report Data Table, 2000. Washington, DC: Department of Energy, 2000.

Environmental Monitoring and Assessment Program, National Health and Environmental Effects Research Laboratory, Western Ecology Division, Office of Research and Development. EPA Mid-Atlantic Highlands Streams Assessment, Aquatic Insect Assemblages, EPA903-R-00-015. Corvalis, OR, Philadelphia, PA, Washington, DC: U.S. Environmental Protection Agency, 2000.

National Academy of Sciences, National Research Council. Committee on Coal Waste Impoundments, Committee on Earth Resources, Board on Earth Sciences and Resources, Division on Earth and Life Studies. Coal Waste Impoundments: Risks, Responses, and Alternatives. Washington DC: National Academy Press, 2002.

United States Bureau of the Census, 2000.

United States Department of Energy. Energy Information Administration. West Virginia coal statistics, 1991, 1996-2000 available from http://www.eia.doe.gov/cnAeaf/coal/cia/a15p01.txt

United States Department of Energy. Energy Information Administration. Monthly Mined Coal Statistics, 2003, available from http://tonto.eia.doe.gov/FTPROOT/coal/weekly/monthprod2003tot.xls.

United States Department of Energy. Energy Information Administration. Monthly Mined Coal Statistics, 2004, available from and http://tonto.eia.doe.gov/FTPROOT/coal/weekly/monthprod2004tot.xls.

United States Department of Energy. Energy Information Administration. Average Open Market Sales Price of Coal by State and Mine Type, 2003, 2002, available from http://www.eia.doe.gov/cneaf/coal/page/acr/table28.html.

U.S. Congress. House. Federal Water Pollution Control Act amendment to clarify that fill material cannot be comprised of waste. $108^{\text {th }}$ Cong., H.R. 738. Bill Summary \& Status for the 108th Congress. Washington, DC: United States Congress, 2003.

U.S. Congress. House. Committee on Government Operations. Environment, Energy, and Natural Resources Subcommittee. Strip Mining and the Flooding in Appalachia: Hearing Before a Subcommittee of the Committee on Government Operations, House of Representatives, ninety-fifth Congress, first session, July 26, 1977. Washington, D.C.: U.S. Govt. Printing Office, 1977.

U.S. Environmental Protection Agency, Mid-Atlantic Region, Environmental Assessment and Innovation Division of the Mid-Atlantic Region. Draft Environmental Impact Statement on Mountaintop Mining. Washington, DC: United States Environmental Protection Agency, 2003. 
U.S. Fish \& Wildlife Service. The Value of Headwater Streams: Results of a Workshop. State College, Pennsylvania: U.S. Fish \& Wildlife Service, 2000.

U.S. Geological Survey Water Resources in Kansas. Summary of Significant Floods, 1970 Through 1989, by Year, available from http://ks.water.usgs.gov/Kansas/pubs/reports/wsp.2502.sum77.html.

U.S. Senate Committee on Environment \& Public Works, Senate Subcommittee on Clean Air. Hearing to review proposed revisions to the wetlands program of the Clean Water Act with respect to "fill material" and "discharge of fill material, statement of Michael Calaghan, Secretary, West Virginia Department of Environmental Protection, $107^{\text {th }}$ Cong., 2d sess., 6 June 2002, available from http://epw.senate.gov/107th/Callaghan_060602.htm.

"Water, sediment, or slurry impoundments and impounding structures." Code of Federal Regulations Title 30, Pt. 77.216, 2003.

Byrd, Robert C., Senate, Senator Robert Byrd of West Virginia speaking to the Senate on mountaintop mining. Congressional Record, November 18, 1999.

Randall, Alan. Estimating Environmental Damages from Surface Mining of Coal in Appalachia: a Case Study. Cincinnati: Industrial Environmental Research Laboratory, Office of Research and Development, U.S. Environmental Protection Agency, 1978.

Shays, Christopher. Press release. Washington, DC: United States Congress, 2003, available from http://www.house.gov/shays/news/2003/february/febpallone.htm.

Wiley, Jeffrey B., Ronald D. Evaldi, James H. Eychaner, and Douglas B. Chambers. Reconnaissance of Stream Geomorphology, Low Streamflow, and Stream Temperature in the Mountaintop Coal-Mining Region, Southern West Virginia, 1999-2000. Report 014092. Charleston, WV: U.S. Department of the Interior, U.S. Geological Survey, in cooperation with the West Virginia Department of Environmental Protection, Office of Mining and Reclamation, Water-Resources Investigations, 2001.

\section{Unpublished Documents and Personal Correspondences}

Byrd, Robert C. to Shirley Stewart Burns. Personal letter. September 17, 2004.

Gibson, Doug for UMWA President Cecil Roberts, to Shirley Stewart Burns. Personal message. October 29, 2004.

Kidd, James David. President of UMWA Local Union 7604. Telephone conversation with author. October 27, 2004. 
Rockefeller, John D. to Shirley Stewart Burns. Personal letter. January 21, 2005.

Zoia, Jim for West Virginia Congressman Nick J. Rahall to Shirley Stewart Burns. Electronic letter. September 28, 2004, Congressman Rahall General Position Paper on Southern West Virginia Coal.

\section{Court Cases}

Ark Land Company v. Rhonda Gail Harper, Edward A. Caudill, Rose M. Thompson, Edith D. Kitchen, Therman R. Caudill, John A. Caudill, Jr., Tammy Willis, and Lucille M. Miller. West Virginia Supreme Court, 2004.

Bragg v. Robertson. U.S.D.C. for the Southern District of West Virginia, Charleston Division, 1998.

Bragg v. West Virginia Coal Association. Fourth Circuit Court of Appeals, 2001.

Flood Litigation, No. 31688, Defendant's Supplemental Brief, Supreme Court of Appeals of West Virginia (August 2, 2004), available from http://www.state.wv.us/wvsca/clerk/cases/FloodLitigation/31688DefendantSupp.pdf.

Flood Litigation, No. 31688, Plaintiff's Supplemental Brief, Supreme Court of Appeals of West Virginia (August 3, 2004), available from http://www.state.wv.us/wvsca/clerk/cases/FloodLitigation/31688PlaintiffSupp.pdf

Kentuckians for the Commonwealth v. Rivenburgh. U.S.D.C. for the Southern District of West Virginia, 2002.

Kentuckians for the Commonwealth v. Rivenburgh. Fourth Circuit Court of Appeals, 2003.

Ohio Valley Environmental Coalition, et al. v. William Bulen. U.S.D.C. for the Southern District of West Virginia, 2004.

Ralph Anderson, et al v. Elk Run Coal Company, Inc. Circuit Court of Boone County, West Virginia, 2003.

West Virginia Coal Association v. Reilly. U.S.D.C. for the Southern District of West Virginia, 1989.

West Virginia Highlands Conservancy v. Norton. U.S.D.C. for the Southern District of West Virginia, Charleston Division, 2001.

\section{Interviews}

Bonds, Judy. Resident of Whitesville, West Virginia. Interview by author. October 8, 2003. 
Canterberry, Pauline. Resident of Sylvester, West Virginia. Interview by author. October 9, 2003.

Miller, Mary. Resident of Sylvester, West Virginia. Interview by author. October 92003.

Sebok, Patty. Resident of Prenter Hollow, West Virginia. Interview by author. October 8, 2003.

\section{Miscellaneous Internet}

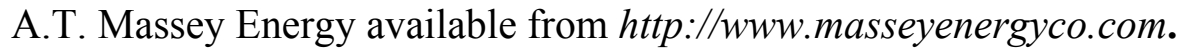

Arch Coal, Inc. available from $h t t p: / / w w w . a r c h c o a l . c o m$.

Babich, Phillip. "Dirty Business," available from http://www.salon.com/tech/feature/2003/11/13/slurry_coverup/index_np.html, November 13, 2003.

Logan County Chamber of Commerce. Earl Ray Tomblin Convention Center. Logan, WV: Logan County Chamber of Commerce, available from http://logancountychamberofcommerce.com/conventcenter.htm.

Mine Impoundment Project. Mine Impoundment Location and Warning System. Wheeling, WV: Robert C. Byrd National Technology Transfer Center \& Wheeling Jesuit Center, 2004, available from http://www.coalimpoundment.com/spill/spillList.asp.

Mineral Information Institute. Golden, CO: Mineral Information Institute, available from http://www.mii.org/reclcoal.html.

Mining Internet Services, Inc. Lexington, KY: Mining Internet Services, Inc., available from http://www.miningusa.com/misi/who_is_misi.htm.

National Mining Association. Post-Mining Land Use. Washington, DC: National Mining Association, available from http://www.nma.org/policy/reclamation/land_use_article.asp.

Ohio Valley Environmental Coalition. Flyer. Mountaintop Removal Mining Fact Sheet. Huntington, WV: Ohio Valley Environmental Coalition, available from http://www.ohvec.org/issues/mountaintop_removal/articles/mtr_fact_sheet.pdf.

\section{Reports}

Center for Business and Economic Research Gatton College of Business and Economics. A Study on the Current Economic Impacts of the Appalachian Coal Industry and its Future in the Region: Final Report. Louisville, KY: University of Kentucky, March 27, 2001. 
Commission on Religion in Appalachia. Social, Economic, and Political Issues Task Force. Strip Mining in Appalachia: a Social, Economic and Political Issue: a Dialogue-focuser. Knoxville, Tenn.: Commission on Religion in Appalachia, 1970.

Massey Energy. 2003 Annual Report. Richmond, VA: Massey Energy Company, 2004.

A Study on the Current Economic Impacts of the Appalachian Coal Industry and its Future in the Region: Final Report. Louisville, KY: Center for Business and Economic Research Gatton College of Business and Economics, University of Kentucky, March 27, 2001.

Surface Mining in West Virginia: the Stanford Report in Perspective, Proceedings of a Symposium held February 26, 1972, Charleston Civic Center, Charleston, W. Va. Charleston, W. Va.: Mid-Appalachian Environmental Service, 1973.

West Virginia People's Election Reform Coalition: Common Cause West Virginia, Ohio Valley Environmental Coalition, West Virginia Citizen Research Group, and West Virginia Citizen Action Group. 2000 Election Cycle Report, available from http://www.wvcag.org/issues/clean_elections/perc2000.pdf.

West Virginia People's Election Reform Coalition: Mountain State Education and Research Foundation, Ohio Valley Environmental Coalition, and West Virginia Citizen Action Group. 2002 Election Cycle Report, available from http://www.wvcag.org/issues/clean_elections/perc2002.pdf.

Eades, Rick. Brushy Fork Slurry Impoundment - A Preliminary Report. Huntington, WV: Ohio Valley Environmental Coalition, 2000.

\section{Books}

Baratz, Morton. The Union and the Coal Industry. Westport, CT: Greenwood Press, 1955.

Battlo, Jean. McDowell County in West Virginia and American History. Parsons, WV: McClain Printing Company, 1998.

Blankenship, Paul. From Cabins to Coal Mines: More History, Sketches, Anecdotes, Traditional Stories, Culture, and Families of Oceana and the Clear Fork Valley of Wyoming County, West Virginia. Beckley, WV: Central Printing, 2002.

Boone County Genealogical Society. Boone County, West Virginia, History, 1990. Madison, WV: Boone County Genealogical Society, 1990.

Bowman, Mary Keller. Reference book of Wyoming County History. Parsons, WV: McClain Print. Co., 1965. 
Brisbin, Jr., Richard Brisbin, Jr. A Strike Like No Other Strike: Law \& Resistance During the Pittston Coal Strike of 1989-1990. Baltimore, MD: John Hopkins University Press, 2002

Brown, William G. History of Nicholas County, West Virginia. Richwood, WV: The News Leader, 1981.

Conley, Phil. History of the West Virginia Coal Industry. Charleston, WV: Education Foundation, Inc., 1960.

Cook, Samuel R. Monacans and Miners: Native American and Coal Mining Communities in Appalachia. Lincoln, NE: University of Nebraska Press, 2000.

Corbin, David. Life, Work, and Rebellion in the Coal Fields: the Southern West Virginia Miners, 1880-1922. Urbana, IL: University of Illinois Press, 1981.

Cuoto, Richard. "The Memory of Miners and the Conscience of Capital: Coal Miners' Strikes as Free Spaces.” In Fighting Back in Appalachia: Traditions of Resistance and Change. Philadelphia: Temple University Press, 1993.

Davis, Donald. Where There are Mountains: an Environmental History of the southern Appalachians. Athens, GA: University of Georgia Press, 2000.

Dix, Keith. What's a Coal Miner to Do?: the Mechanization of Coal Mining. Pittsburgh, PA: University of Pittsburgh Press, 1988.

Domhoff, William . Who Rules America: Power and Politics. Boston: McGraw-Hill Higher Education, 2002.

Dunaway, Wilma. The First American Frontier: Transition to Capitalism in southern Appalachia, 1700-1860. Chapel Hill: the University of North Carolina Press, 1996.

Eller, Ronald. Miners, Millhands, and Mountaineers: Industrialization of the Appalachian South, 1880-1930. Knoxville, Tenn: University of Tennessee Press, 1982.

Evans, Sara and Harry Boyte. Free Space: the Sources of Dramatic Change in America. New York, NY: Harper \& Row, 1986.

Fayette County Chamber of Commerce. History of Fayette County, West Virginia. Oak Hill, WV: Fayette County Chamber of Commerce, 1993.

Fox, Maier B. United We Stand: the United Mine Workers of America, 1890-1990. Washington, DC: United Mine Workers of America, 1990.

Freese, Barbara. Coal: A Human History. Cambridge: MA: Perseus Books Group, 2003. 
Gaventa, John. Power and Powerlessness: Quiescence and Rebellion in an Appalachian Valley. Urbana, IL: University of Illinois Press, 1980.

Harris, V.B. Great Kanawha: An Historical Outline. Charleston, WV: Kanawha County Court, for the bicentennial celebration, 1976.

Hatcher, Thomas, Steele, Geneva, Long, Sandra, and McGuire, Christine Carr, eds. The Heritage of McDowell County, West Virginia, 1858-1995. War, WV: McDowell County Historical Society, 1995.

Judkins, Bennett . "The People's Respirator: Coalition Building and the Black Lung Association.” In Fighting Back in Appalachia: Traditions of Resistance and Change. Philadelphia: Temple University Press, 1993.

Kephart, Horace. Our Southern Highlanders: a Narrative of Adventure in the Southern Appalachians and a Study of Life Among the Mountaineers. Knoxville, Tenn: University of Tennessee Press, 1976.

Lee, Howard B. Bloodletting in Appalachia: The Story of West Virginia's Four Major Mine Wars and Other Thrilling Incidents of Its Coal Fields. Morgantown, WV: West Virginia University, 1969.

Lewis, Ronald L. and John Hennen. West Virginia: Documents in the History of a RuralIndustrial State. Dubuque, IA: Kendall/Hunt Publishing Company, 1991.

Lewis, Ronald L. Transforming the Appalachian Countryside: Railroads, Deforestation, and Social Change in West Virginia, 1880-1920. Chapel Hill: University of North Carolina Press, 1998.

Lewis, Virgil. History of West Virginia. In Two Parts. Philadelphia: Hubbard Brothers Publishers, 1889.

Lunt, Richard D. Law \& Order vs the Miners: WV 1906-1933. Charleston, WV: Appalachian Editions, 1992.

Lutz, Paul. From Governor to Cabby: the Political Career and Tragic Death of West Virginia's William Casey Marland, 1950-1965. Huntington, WV: the Marshall University Library Associates, 1996.

Marland, William C. "Governor William C. Marland Proposes The Severance Tax," In West Virginia: Documents in the History of a Rural-Industrial State edited by Ronald Lewis and John Hennen. Dubuque, IA: Kendall/Hunt Publishing Company, 1991.

McLean, Iain \& Martin Johnes. Aberfan: Government \& Disasters. Cardiff, Wales: Welsh Academic Press, 2000. 
Meyers, Robert A., ed. Coal Handbook. New York: M. Dekker, 1981.

Miller, Tom. Who Owns West Virginia? Huntington, WV: Herald Adviser and the HeraldDispatch, 1974.

Montrie, Chad. To Save the Land and the People: A History of Opposition to Surface Coal Mining in Appalachia. Chapel Hill, NC: University of North Carolina Press, 2003.

Morris, Homer. The Plight of the Bituminous Coal Miner. Philadelphia, University of Pennsylvania Press; London, H. Milford, Oxford University Press, 1934.

Payne, Neil F. and Fred C. Bryant. Techniques for Wildlife Habitat Management of Uplands. New York, NY: McGraw-Hill, Inc., 1994.

Rasmussen, Barbara. Absentee Landowning \& Exploitation in West Virginia, 1760-1920. Lexington, KY: University Press of Kentucky, 1994.

Rice, Otis. West Virginia: The State and Its People. Parsons, WV: McClain Printing Company, 1972.

Rice, Otis and Stephen Brown. West Virginia: A History. Lexington, KY: University Press of Kentucky, 1993.

Salstrom, Paul. Appalachia's Path to Dependency: Rethinking a Region's Economic History, 1730-1940. Lexington, KY: University Press of Kentucky, 1994.

Session, Jim and Fran Ansley. "Singing Across Dark Spaces: the Union/Community Takeover of Pittston's Moss 3 Plant." In Fighting Back in Appalachia: Traditions of Resistance and Change. Philadelphia: Temple University Press, 1993.

Shifflett, Crandall. Coal Towns: Life, Work, and Culture in Company Towns of Southern Appalachia, 1880-1960. Knoxville, TN: University of Tennessee Press, 1991.

Shogan, Robert. The Battle of Blair Mountain: the Story of America's Largest Labor Uprising. Boulder, CO: Westview Press, 2004.

Smith, Barbara Ellen. Digging Our Own Graves: Coal Miners and the Struggle over Black Lung Disease. Philadelphia, PA: Temple University Press, 1987.

Squillace, Mark. Strip Mining Handbook: a Coalfield Citizens' Guide to Using the Law to Fight Back Against the Ravages of Strip Mining and Underground Mining. Washington, D.C.: Environmental Policy Institute and Friends of the Earth, 1990.

Stacks, John F. Stripping. San Francisco: Sierra Club, 1972. 
Stealey, III, John E. The Antebellum Kanawha Salt Business \& Western Markets. Lexington, KY: University Press of Kentucky, 1993.

Sullivan, Ken, ed. The Goldenseal Book of the West Virginia Mine Wars. Charleston: Pictorial Histories Publishing, 1991.

Thurmond, Walter R. Logan Coal Field of West Virginia: a Brief History. Morgantown, West Virginia University Library, 1964.

Walls, David S. "Internal Colony or Internal Periphery: a Critique of Current Models and an alternative Formulation." In Colonialism in Modern America: the Appalachian Case. Boone, NC: the Appalachian Consortium Press, 1978.

White, E.B. Essays of E.B. White. New York, New York: First Perennial Classics, division of Harper Collins, 1999.

Williams, John Alexander. West Virginia and the Captains of Industry. Morgantown, WV: West Virginia University Library, 1997, reprint edition.

William, John Alexander. West Virginia: A History. Morgantown, WV: West Virginia University Press, 2001.

Woods, Jim. Raleigh County, West Virginia. Beckley, WV: BJW Printing \& Office Supplies, 1994.

\section{Dissertations and Theses}

Ammer, Frank. "Population Level Dynamics of Grasshopper Sparrow Populations Breeding on Reclaimed Mountaintop Mines in West Virginia." Ph.D. diss., West Virginia University, 2003.

Bailey, Rebecca J. "Matewan Before the Massacre: Politics, Coal, and the Roots of Conflict in Mingo County, 1793-1920.” Ph.D. diss., West Virginia University, 2001.

Balcerzak, Melissa. "Raptor Abundance and Diversity and Red-shouldered Hawk (Buteo lineatus) Habitat Characteristics on Reclaimed Mountaintop Mines in Southern West Virginia.” M.A. Thesis, West Virginia University, 2001.

Chamblin, Douglass. "Small Mammal Communities on a Reclaimed Mountaintop Mine/Valley Fill Landscape in Southern West Virginia.” M.A. Thesis, West Virginia University, 2002.

Hansbarger, Jeff. "Mountaintop Removal Mining: An Environmental Impact Assessment (EIA) Scoping Exercise and Impact Assessment of Mining Activities on Aquatic Resources." M.A. Thesis, West Virginia University, 2000. 
Kolli, Shiva. "Analyses of Coal Extraction and Spoil Handling Techniques in Mountainous Areas.” M.A. Thesis, West Virginia University, 2001.

Montrie, Chad. "To Save the Land and People: a History of Opposition to Coal Surface Mining in Appalachia.” Ph.D. diss., Ohio State University, 2001.

Peter, David. "Earnings, Health, Safety, and Welfare of Bituminous Coal Miners Since the Encouragement of Mechanization by the United Mine Workers of America," Ph.D. diss., West Virginia University, 1972.

Rakes, Paul. "Acceptable Casualties: Power, Culture, and History in the West Virginia Coalfields, 1900-1945.” Ph.D. diss., West Virginia University, 2002.

Underwood, Deborah. "The Ascendancy of Surface Mining over Underground Mining in the United States Coal Industy: Effects on and Issues Relevant to the United Mine Workers of America.” M.A. Thesis, University of Montana, 1987.

Walls, David S. “Central Appalachia in Advanced Capitalism.” Ph.D. diss., University of Kentucky, 1978.

Wells, Jr., John Calhoun. "Poverty Amidst Riches: Why People are Poor in Appalachia." Ph.D. diss., Rutgers University, 1977.

\section{Journal Articles}

Crotty, Michael G. "Bragg v. West Virginia Mining Association: the Eleventh Amendment Challenge to Mountaintop Coal Mining." Villanova Environmental Law Journal 13 (2002): 287-311.

Fishback, Price."Did Coal Miners 'Owe Their Souls to the Company Store?"' Theory and Evidence from the Early 1900s," The Journal of Economic History 46 (Dec. 1986), 1011 1029.

Hammond, Christiadi and George Hammond. "How well did we retain and attract highly educated workers?" West Virginia University College of Business and Economics, West Virginia Business and Economic Review 9 (2003): 1-6.

Leopold, Aldo. “Wildlife in American Culture," Journal of Wildlife Management 7(1) (1943): 16.

McGinley, Patrick. "From Pick and Shovel to Mountaintop Removal: Environmental Injustice in the Appalachian Coalfields." Environmental Law Vol. 34, No. 1 (2004): 21-106.

Munn, Robert . "The First Fifty Years of Strip Mining in West Virginia, 1916-1965.” West Virginia History 35 (October 1973): 66-74. 
Munn, Robert. "The Development of Model Towns in the Bituminous Coal Fields." West Virginia History 40 (Spring 1979): 243-253.

Rasmussen, Barbara. "The Politics of the Property Tax in West Virginia." Journal of Appalachian Studies 2 (1): 141-147.

Rice, Otis. "Coal Mining in the Kanawha Valley to 1861: A View of Industrialization in the Old South.” The Journal of Southern History 31 (November 1965): 393-416.

Skousen, Jeff, Paul Ziemkiewicz, and Christina Venable. "Evaluation of Tree Growth on Surface Mined Lands in Southern West Virginia." Morgantown, WV: Agricultural \& Natural Resources Development, Extension service, 1998, available from http://www.wvu.edu/ agexten/landrec/evaltree.htm. First published in Green Lands (Winter 1998).

Veldhuis, Niek. "Sumerian Proverbs in their Curricular Context." Journal of the American Oriental Society 3, 2000.

Williams, Ted. "Mountain Madness.” Audubon Magazine (May/June 2001).

\section{Studies, Public Correspondences, and Organizational Press Releases}

American Rivers. Press release. Coal River Listed Among Nation's Most Endangered Rivers. Washington, D.C.: American Rivers, 2000.

Center for Economic Research. Boone County, WV, County Data. Morgantown, WV: West Virginia University, 1991.

Center for Economic Research. Fayette County, WV, County Data. Morgantown, WV: West Virginia University, 1991.

Center for Economic Research. Kanawha County, WV, County Data. Morgantown, WV: West Virginia University, 1991.

Center for Economic Research. Logan County, WV, County Data. Morgantown, WV: West Virginia University, 1991.

Center for Economic Research. McDowell County, WV, County Data. Morgantown, WV: West Virginia University, 1991.

Center for Economic Research. Mingo County, WV, County Data. Morgantown, WV: West Virginia University, 1991.

Center for Economic Research. Nicholas County, WV, County Data. Morgantown, WV: West Virginia University, 1991. 
Coal Operators and Associates, the Kentucky Coal Association, the National Mining Association, the Ohio Coal Association, and the West Virginia Coal Association to John Forren, US EPA. Letter, Joint Coal Industry Comments on the Mountaintop Mining/Valley Fill Draft Environmental Impact Statement. Charleston, WV: West Virginia Coal Association, January 6, 2004, available from http://www.wvcoal.com/resources/pdfs/FinalEIS.pdf.

Kentucky Department for Environmental Protection, Division of Water, Water Quality Branch. A Macroinvertebrate Bioassessment Index for Headwater Streams of the Eastern Coalfield Region, KY. Frankfort, KY: Kentucky Department for Environmental Protection, 2002.

Lake, Snell, Perry and Associates. "New Poll Findings On Mountaintop Removal in West Virginia. Opposition to mountaintop removal is broad and deep." Conducted for Appalachian Center for the Economy and the Environment, available from http://www.appalachian-center.org/poll_results/index.html.

Massachusetts Taxpayers Foundation. Massachusetts' Tax Burden Falls to Bottom Tier of States. Boston, MA: Massachusetts Taxpayers Foundation, 2004.

Ohio Valley Environmental Coalition. Comments on Draft Programmatic Environmental Impact Statement on Mountaintop Removal Mining/Valley Fill Activities in Appalachia: The Social and Cultural Effects of Mountaintop Removal/ Valley Fill Coal Mining. Huntington, WV: Ohio Valley Environmental Association, 2004.

Trial Lawyers for Public Justice. Press Release. Citizens' Group and TLPJ Sue Federal and State Regulators to Fix West Virginia's Coal Mining Program. Washington, D.C.: Trial Lawyers for Public Justice, 2000, available from http://www.tlpj.org/pr/wv_coal.htm.

West Virginia Coal Association. Coal Education Development and Resource of Southern West Virginia, Inc. (CEDAR). Charleston, WV: West Virginia Coal Association, 2004.

West Virginia Coal Association. West Virginia Coal Facts 2001. Charleston, WV: West Virginia Coal Association, 2001.

West Virginia Coal Association. West Virginia Coal Facts 2003. Charleston, WV: West Virginia Coal Association, 2003.

The Wilderness Society. Press Release. Rahall Wins Ansel Adams Award for Efforts to Protect Nation's Lands. Washington, DC: the Wilderness Society, 2004.

Condon, Chris, Randy Childs, and Leah Bogdan. County Data Profile: Boone County. Morgantown, WV: Bureau of Business and Economics, West Virginia University, September 2000. 
Condon, Chris, Randy Childs, and Leah Bogdan. County Data Profile: Fayette County. Morgantown, WV: Bureau of Business and Economics, West Virginia University, September 2000.

Condon, Chris, Randy Childs, and Leah Bogdan. County Data Profile: Kanawha County. Morgantown, WV: Bureau of Business and Economics, West Virginia University, September 2000.

Condon, Chris, Randy Childs, and Leah Bogdan. County Data Profile: Logan County. Morgantown, WV: Bureau of Business and Economics, West Virginia University, September 2000.

Condon, Chris, Randy Childs, and Leah Bogdan. County Data Profile: McDowell County. Morgantown, WV: Bureau of Business and Economics, West Virginia University, September 2000.

Condon, Chris, Randy Childs, and Leah Bogdan. County Data Profile: Mingo County. Morgantown, WV: Bureau of Business and Economics, West Virginia University, September 2000.

Condon, Chris, Randy Childs, and Leah Bogdan. County Data Profile: Nicholas County. Morgantown, WV: Bureau of Business and Economics, West Virginia University, September 2000.

Condon, Chris, Randy Childs, and Leah Bogdan. County Data Profile: Raleigh County. Morgantown, WV: Bureau of Business and Economics, West Virginia University, September 2000.

Condon, Chris, Randy Childs, and Leah Bogdan. County Data Profile: Wyoming County. Morgantown, WV: Bureau of Business and Economics, West Virginia University, September 2000.

Hartman, Kyle. Effects of Valley Fill Mining upon Aquatic Macroinvertebrate Communities in Southern West Virginia. Morgantown, WV: West Virginia University, available from http://www.forestry.caf.wvu.edu/programs/Wildlife\&fisheries/Research.htm.

Thomas, K.A., Jeffrey Skousen, John Sencindiver, and Jim Gorman. Soil Horizon Development on a Mountaintop Surface Mine in Southern West Virginia. Morgantown WV: West Virginia University, Agriculture Extension, 2000, available from http://www.wvu.edu/ agexten/landrec/soilhori.htm.

Vendetti, Jann. Mining: Storing Coal Slurry. American Geological Institute. Alexandria, VA: American Geological Institute, 2004.

Ward, Ken. Mining the Mountains series. Charleston Gazette. 


\section{Media}

All Shaken Up, prod. and dir. Bob Gate, Penny Loeb. 32 min., Omni Productions, 1998, videocassette.

Wheeler, Billy Edd. Coal Tattoo. Ode to the Little Brown Shack Out Back, Kapp Records KL$1425,1963$. 


\section{Appendix 1}

Citizen's to Abolish Surface Mining, Guest Editorial

February 1972

John D. Rockefeller, IV

(Excerpt from a speech at Morris Harvey College, January 15, 1972)

Government has turned its back on the many West Virginians who have borne out of their own property and out of their own pocketbooks the destructive impact of stripping.

We hear that our Governor once claimed to have wept as he flew over the strip mine devastation of this state.

Now it's the people who weep.

They weep because of the devastation of our mountains, because of the disaster of giant high walls, acid-laden benches, and bare, precipitous outslopes which support no vegetation at all but erode thousands of tons of mud and rocks into the streams and rivers below.

Strip-mining must be abolished because of its effect on those who have given most to the cause - the many West Virginians who have suffered actual destruction of their homes; those who have put up with flooding, mud slides, cracked foundations, destruction of neighborhoods, decreases in property values, the loss of fishing and hunting, and the beauty of the hills.

And we are not alone in our feeling.

West Virginians love their hills. We identify ourselves with our hills, and are not about to let our hills be torn aside and demolished so that a small fraction of the coal beneath them can be taken away.

And we can make a difference.

But if we are to communicate as an abolition movement, we have to stretch ourselves further.

It's not enough just to be against strip-mining. In the emotion of seeing a newlyclobbered hill, it's easy to forget the largest justification for abolition. The strongest arguments, other than environmental ones, can be made for abolition on economic terms. And we have to manifest concern for new industries and jobs in West Virginia.

We are trying to affect the overall economic development of West Virginia, and we can show the linkage between abolition and long-term economic development.

The overwhelming percentage of our coal can only be obtained by deep mining. We know that. And we know that when the industry is cured of its binge of exploitation stripping, and returns to real mining, there will be more jobs for West Virginians - jobs that contribute to our prosperity without destroying the communities and counties in which they are located.

We can be a powerful force toward both halting the destruction of our state and also toward coming up with economically sound alternatives that will demonstrate best to all people that we have the long-term economic interests of the state at heart. ${ }^{3}$

\footnotetext{
${ }^{3}$ John D. Rockefeller, IV, “Excerpts from a speech at Morris Harvey College, January 15, 1972," Stripmining collection, A\&M 2618, Box 1, ff1, West Virginia Collection, West Virginia University.
} 


\begin{tabular}{|c|c|c|c|c|c|c|}
\hline \multicolumn{7}{|c|}{ Appendix 2} \\
\hline County & $\begin{array}{c}\text { Coal } \\
\text { Company }\end{array}$ & Dam Name & $\begin{array}{l}\text { Height } \\
\text { (ft) }\end{array}$ & $\begin{array}{l}\text { Capacity } \\
\text { (gallons) }\end{array}$ & $\begin{array}{c}\text { DEP } \\
\text { Classification }\end{array}$ & $\begin{array}{c}\text { MSHA } \\
\text { Risk } \\
\text { Level } \\
\text { (Hazard } \\
\text { Potential) } \\
\end{array}$ \\
\hline Boone & $\begin{array}{l}\text { Elk Run Coal } \\
\text { Company }\end{array}$ & $\begin{array}{l}\text { Chess } \\
\text { Processing } \\
\text { Refuse } \\
\text { Disposal Area } \\
\text { No. } 1\end{array}$ & 410 & 769 million & Class C & High \\
\hline Boone & $\begin{array}{l}\text { Jupiter Coal } \\
\text { Company, } \\
\text { Inc. }\end{array}$ & $\begin{array}{l}\text { Pond Fork } \\
\text { Slurry } \\
\text { Impoundment }\end{array}$ & 290 & 267.85 million & Class C & High \\
\hline Boone & $\begin{array}{l}\text { Eastern } \\
\text { Associated } \\
\text { Coal Corp }\end{array}$ & $\begin{array}{l}\text { Rocklick Br. } \\
\text { Refuse } \\
\text { Impoundment }\end{array}$ & 390 & 3.0174 billion & Class C & Moderate \\
\hline Boone & $\begin{array}{l}\text { Eastern } \\
\text { Associated } \\
\text { Coal Corp }\end{array}$ & $\begin{array}{l}\text { Jarrells Br. } \\
\text { Refuse } \\
\text { Impoundment }\end{array}$ & 385 & 2.2810 billion & Class C & Moderate \\
\hline Boone & $\begin{array}{l}\text { Pine Ridge } \\
\text { Coal } \\
\text { Company }\end{array}$ & $\begin{array}{l}\text { Spruce Lick } \\
\text { Refuse } \\
\text { Impoundment }\end{array}$ & 420 & 1.5618 billion & Class C & High \\
\hline Boone & $\begin{array}{l}\text { Omar Mining } \\
\text { Company }\end{array}$ & $\begin{array}{l}\text { Road Fork } \\
\text { Coal Refuse } \\
\text { Disposal } \\
\text { Facility }\end{array}$ & 500 & 2.9594 billion & Class C & High \\
\hline Boone & $\begin{array}{l}\text { Independence } \\
\text { Coal } \\
\text { Company }\end{array}$ & $\begin{array}{l}\text { Elisa Fork } \\
\text { Slurry } \\
\text { Impoundment }\end{array}$ & 800 & 769.01 million & Class C & Low \\
\hline Boone & $\begin{array}{l}\text { Eagle Energy, } \\
\text { Inc. }\end{array}$ & $\begin{array}{l}\text { Brown's } \\
\text { Branch Slurry } \\
\text { Impoundment }\end{array}$ & 183 & $619,157,484$ & Class C & Low \\
\hline Boone & $\begin{array}{l}\text { Catenary } \\
\text { Coal } \\
\text { Company }\end{array}$ & $\begin{array}{l}\text { Moccasin } \\
\text { Hollow Slurry } \\
\text { Impoundment }\end{array}$ & 310 & $837,642,184$ & $\mathrm{~N} / \mathrm{A}$ & High \\
\hline Boone & $\begin{array}{l}\text { Kanawha } \\
\text { Eagle, LLC }\end{array}$ & $\begin{array}{l}\text { Slippery Gut } \\
\text { Slurry } \\
\text { Impoundment }\end{array}$ & 280 & $1,717,964,697$ & Class C & N/A \\
\hline Boone & $\begin{array}{l}\text { Jacks Branch } \\
\text { Coal } \\
\text { Company }\end{array}$ & $\begin{array}{l}\text { Crooked Run } \\
\text { Impoundment }\end{array}$ & 350 & $2,769,334,331$ & Class C & $\mathrm{N} / \mathrm{A}$ \\
\hline Boone & $\begin{array}{l}\text { Independence } \\
\text { Coal } \\
\text { Company }\end{array}$ & $\begin{array}{l}\text { Jake Gore } \\
\text { Slurry } \\
\text { Impoundment }\end{array}$ & 650 & 4.3664 billion & Class C & N/A \\
\hline Boone & $\begin{array}{l}\text { Wind River } \\
\text { Resources } \\
\text { Corp }\end{array}$ & $\begin{array}{l}\text { Plant One } \\
\text { Coal Refuse } \\
\text { Disposal }\end{array}$ & 270 & $670,971,189$ & $\mathrm{~N} / \mathrm{A}$ & Low \\
\hline Boone & $\begin{array}{l}\text { Pine Ridge } \\
\text { Coal } \\
\text { Company }\end{array}$ & $\begin{array}{l}\text { Lotts Fork } \\
\text { Refuse } \\
\text { Impoundment }\end{array}$ & 354 & $985,763,889$ & Class C & Low \\
\hline
\end{tabular}




\begin{tabular}{|c|c|c|c|c|c|c|}
\hline County & $\begin{array}{c}\text { Coal } \\
\text { Company }\end{array}$ & Dam Name & $\begin{array}{l}\text { Height } \\
\text { (ft) }\end{array}$ & $\begin{array}{l}\text { Capacity } \\
\text { (gallons) }\end{array}$ & $\begin{array}{c}\text { DEP } \\
\text { Classification }\end{array}$ & $\begin{array}{c}\text { MSHA } \\
\text { Risk } \\
\text { Level } \\
\text { (Hazard } \\
\text { Potential) }\end{array}$ \\
\hline Kanawha & $\begin{array}{l}\text { Cannelton } \\
\text { Industries, } \\
\text { Inc. }\end{array}$ & $\begin{array}{l}\text { Dunn Hollow } \\
\text { Coal Refuse } \\
\text { Dam }\end{array}$ & 400 & 1.2806 billion & Class C & High \\
\hline Kanawha & $\begin{array}{l}\text { Catenary } \\
\text { Coal } \\
\text { Company }\end{array}$ & $\begin{array}{l}\text { Campbell's } \\
\text { Creek Slurry } \\
\text { Impoundment }\end{array}$ & 360 & 545.5 million & Class C & Moderate \\
\hline Kanawha & $\begin{array}{l}\text { Kanawha } \\
\text { Eagle, LLC }\end{array}$ & $\begin{array}{l}\text { New West } \\
\text { Hollow } \\
\text { Impoundment }\end{array}$ & 190 & 609.67 million & Class C & High \\
\hline Logan & $\begin{array}{l}\text { Hobet Mining, } \\
\text { Inc. }\end{array}$ & $\begin{array}{l}\text { Monclo } \\
\text { Refuse Dam/ } \\
\text { Impoundment }\end{array}$ & 450 & 1.4119 billion & Class C & High \\
\hline Logan & $\begin{array}{l}\text { Falcon Land } \\
\text { Company, } \\
\text { Inc. }\end{array}$ & $\begin{array}{l}\text { Holden No. } 22 \\
\text { Slurry } \\
\text { Impoundment }\end{array}$ & 330 & $912,251,308$ & Class C & Low \\
\hline Logan & $\begin{array}{l}\text { Island Creek } \\
\text { Coal } \\
\text { Company }\end{array}$ & $\begin{array}{l}\text { Elk Creek No. } \\
10 \text { Slurry } \\
\text { Impoundment }\end{array}$ & 280 & $944,831,712$ & Class C & Low \\
\hline Logan & $\begin{array}{l}\text { Logan Mining } \\
\text { Company }\end{array}$ & $\begin{array}{l}\text { Holden No. } 29 \\
\text { Slurry } \\
\text { Impoundment }\end{array}$ & 320 & 793.12 million & Class C & High \\
\hline Logan & $\begin{array}{l}\text { Apogee Coal } \\
\text { Company } \\
\text { d/b/a Arch of } \\
\text { WV }\end{array}$ & $\begin{array}{l}\text { Little White } \\
\text { Oak Slurry } \\
\text { Impoundment }\end{array}$ & 360 & $185,421,372$ & Class C & Low \\
\hline Logan & $\begin{array}{l}\text { Hobet Mining, } \\
\text { Inc. }\end{array}$ & $\begin{array}{l}\text { Pine Creek } \\
\text { Slurry } \\
\text { Impoundment }\end{array}$ & 285 & 1.0264 billion & Class C & High \\
\hline Logan & $\begin{array}{l}\text { Stirrat Coal } \\
\text { Company }\end{array}$ & $\begin{array}{l}\text { Rockhouse } \\
\text { Mitigation Pond }\end{array}$ & 50 & $66,138,219$ & Class A & N/A \\
\hline McDowell & $\begin{array}{l}\text { Mid-Vol } \\
\text { Leasing,Inc. }\end{array}$ & $\begin{array}{l}\text { Harmon } \\
\text { Branch Coal } \\
\text { Refuse } \\
\text { Disposal } \\
\text { Facility }\end{array}$ & 281 & 186.71 million & $\begin{array}{l}\text { No } \\
\text { Information } \\
\text { Listed }\end{array}$ & High \\
\hline McDowell & $\begin{array}{l}\text { Virginia } \\
\text { Crews Coal } \\
\text { Company }\end{array}$ & $\begin{array}{l}\text { Lick Branch } \\
\text { Slurry } \\
\text { Impoundment }\end{array}$ & $\mathrm{N} / \mathrm{A}$ & N/A & Class C & High \\
\hline McDowell & $\begin{array}{l}\text { Consolidation } \\
\text { Coal } \\
\text { Company }\end{array}$ & $\begin{array}{l}\text { Amonate } \\
\text { Slurry Dam }\end{array}$ & 375 & 1.6130 billion & Class C & N/A \\
\hline McDowell & $\begin{array}{l}\text { Consolidation } \\
\text { Coal } \\
\text { Company }\end{array}$ & $\begin{array}{l}\text { Belcher } \\
\text { Branch Coal } \\
\text { Refuse Dam }\end{array}$ & 298 & $1,029,690,510$ & Class C & $\mathrm{N} / \mathrm{A}$ \\
\hline McDowell & $\begin{array}{l}\text { Mineral } \\
\text { Development } \\
\text { Corporation }\end{array}$ & $\begin{array}{l}\text { Grapevine } \\
\text { Branch } \\
\text { Impoundment } \\
\text { Pond 1 }\end{array}$ & 430 & 490.08 million & Class C & Moderate \\
\hline
\end{tabular}




\begin{tabular}{|c|c|c|c|c|c|c|}
\hline County & $\begin{array}{c}\text { Coal } \\
\text { Company }\end{array}$ & Dam Name & $\begin{array}{l}\text { Height } \\
\text { (ft) }\end{array}$ & $\begin{array}{l}\text { Capacity } \\
\text { (gallons) }\end{array}$ & $\begin{array}{c}\text { DEP } \\
\text { Classification }\end{array}$ & $\begin{array}{c}\text { MSHA } \\
\text { Risk } \\
\text { Level } \\
\text { (Hazard } \\
\text { Potential) }\end{array}$ \\
\hline McDowell & $\begin{array}{l}\text { West Virginia } \\
\text { Properties, } \\
\text { Inc. }\end{array}$ & $\begin{array}{l}\text { Barrenshe } \\
\text { Branch Fine } \\
\text { Coal Refue } \\
\text { Disposal Area }\end{array}$ & 90 & $228,062,827$ & Class C & Low \\
\hline McDowell & $\begin{array}{l}\text { Mineral } \\
\text { Development } \\
\text { Corporation }\end{array}$ & $\begin{array}{l}\text { Grapevine } \\
\text { Branch } \\
\text { Impoundment } \\
\text { Pond } 2\end{array}$ & 510 & 2.2441 billion & Class C & Moderate \\
\hline McDowell & $\begin{array}{l}\text { Cannelton } \\
\text { Industries, } \\
\text { Inc. }\end{array}$ & $\begin{array}{l}\text { Elkhorn Creek } \\
\text { Coal Refuse } \\
\text { Dam }\end{array}$ & 157 & 76.2 million & Class C & $\mathrm{N} / \mathrm{A}$ \\
\hline McDowell & $\begin{array}{l}\text { Consolidation } \\
\text { Coal } \\
\text { Company }\end{array}$ & $\begin{array}{l}\text { Dalton's } \\
\text { Branch Coal } \\
\text { Refuse Dam }\end{array}$ & 305 & $2,320,211,203$ & Class C & $\mathrm{N} / \mathrm{A}$ \\
\hline McDowell & $\begin{array}{l}\text { Second } \\
\text { Sterling Corp. }\end{array}$ & $\begin{array}{l}\text { Clark Branch } \\
\text { Coal Refuse } \\
\text { Dam }\end{array}$ & 63 & $1,009,878,443$ & Class C & Moderate \\
\hline Mingo & $\begin{array}{l}\text { Mingo Logan } \\
\text { Coal } \\
\text { Company }\end{array}$ & $\begin{array}{l}\text { Ben Creek } \\
\text { Slurry } \\
\text { Impoundment }\end{array}$ & 390 & 5.2038 billion & Class C & High \\
\hline Mingo & $\begin{array}{l}\text { Mingo Logan } \\
\text { Coal } \\
\text { Company }\end{array}$ & $\begin{array}{l}\text { Ragland Coal } \\
\text { Refuse } \\
\text { Impoundment }\end{array}$ & 345 & 4.7411 billion & Class C & Moderate \\
\hline Mingo & $\begin{array}{l}\text { Old Ben Coal } \\
\text { Company }\end{array}$ & $\begin{array}{l}\text { Nile Stone } \\
\text { Slurry } \\
\text { Impoundment }\end{array}$ & 215 & $N / A$ & Class C & $\mathrm{N} / \mathrm{A}$ \\
\hline Mingo & $\begin{array}{l}\text { Tug Valley } \\
\text { Coal } \\
\text { Processing } \\
\text { Company }\end{array}$ & $\begin{array}{l}\text { Aldrich } \\
\text { Branch Coal } \\
\text { Refuse } \\
\text { Impoundment }\end{array}$ & 270 & $4,294,097,233$ & $N / A$ & Low \\
\hline Mingo & None Listed & $\begin{array}{l}\text { Delbarton } \\
\text { Impoundment }\end{array}$ & $\begin{array}{c}\text { Not } \\
\text { listed }\end{array}$ & $\mathrm{N} / \mathrm{A}$ & $\mathrm{N} / \mathrm{A}$ & $\mathrm{N} / \mathrm{A}$ \\
\hline Mingo & None Listed & $\begin{array}{l}\text { Left Fork } \\
\text { Impoundment }\end{array}$ & $\begin{array}{l}\text { Not } \\
\text { listed }\end{array}$ & $\mathrm{N} / \mathrm{A}$ & $\mathrm{N} / \mathrm{A}$ & $\mathrm{N} / \mathrm{A}$ \\
\hline Mingo & $\begin{array}{l}\text { Mingo Logan } \\
\text { Coal } \\
\text { Company }\end{array}$ & $\begin{array}{l}\text { Ben Creek \#1 } \\
\text { Freshwater } \\
\text { Impoundment }\end{array}$ & $\begin{array}{l}\text { Not } \\
\text { listed }\end{array}$ & $N / A$ & $N / A$ & $N / A$ \\
\hline Mingo & $\begin{array}{l}\text { Greyeagle } \\
\text { Coal Comp } \\
\text { (Kermit Coal } \\
\text { Comp) }\end{array}$ & $\begin{array}{l}\text { Left Fork Coal } \\
\text { Refuse } \\
\text { Impoundment }\end{array}$ & 121 & 336.3 million & $N / A$ & $\mathrm{~N} / \mathrm{A}$ \\
\hline Mingo & $\begin{array}{l}\text { Rawl Sales } \\
\text { and } \\
\text { Processing, } \\
\text { Co. }\end{array}$ & $\begin{array}{l}\text { Sprouse } \\
\text { Creek Slurry } \\
\text { Impoundment }\end{array}$ & 625 & 4.0080 billion & Class C & Low \\
\hline Mingo & $\begin{array}{l}\text { Laurel Creek } \\
\text { Company, } \\
\text { Inc. }\end{array}$ & $\begin{array}{l}\text { Twelvepole } \\
\text { Refuse } \\
\text { Impoundment }\end{array}$ & 211 & 716.87 million & $\mathrm{N} / \mathrm{A}$ & $\mathrm{N} / \mathrm{A}$ \\
\hline
\end{tabular}




\begin{tabular}{|c|c|c|c|c|c|c|}
\hline County & $\begin{array}{c}\text { Coal } \\
\text { Company }\end{array}$ & Dam Name & $\begin{array}{l}\text { Height } \\
\text { (ft) }\end{array}$ & $\begin{array}{l}\text { Capacity } \\
\text { (gallons) }\end{array}$ & $\begin{array}{c}\text { DEP } \\
\text { Classification }\end{array}$ & $\begin{array}{c}\text { MSHA } \\
\text { Risk } \\
\text { Level } \\
\text { (Hazard } \\
\text { Potential) }\end{array}$ \\
\hline Mingo & $\begin{array}{l}\text { Marrowbone } \\
\text { Development } \\
\text { Company }\end{array}$ & $\begin{array}{l}\text { Spruce Fork } \\
\text { Coal Refuse } \\
\text { Impoundment }\end{array}$ & 145 & 14.7 million & $N / A$ & $N / A$ \\
\hline Nicholas & $\begin{array}{l}\text { Gauley Eagle } \\
\text { Holdings, Inc. }\end{array}$ & $\begin{array}{l}\text { Crooked Run } \\
\text { Coal Refuse } \\
\text { Dam }\end{array}$ & 100 & 848.51 million & Class C & High \\
\hline Nicholas & $\begin{array}{l}\text { Peerless } \\
\text { Eagle Coal } \\
\text { Comp. }\end{array}$ & $\begin{array}{l}\text { Rockcamp } \\
\text { Branch \#2 } \\
\text { Refuse Dam }\end{array}$ & $\begin{array}{l}\text { Not } \\
\text { listed }\end{array}$ & N/A & N/A & N/A \\
\hline Raleigh & $\begin{array}{l}\text { Marfork Coal } \\
\text { Company }\end{array}$ & $\begin{array}{l}\text { Brushy Fork } \\
\text { Coal } \\
\text { Impoundment }\end{array}$ & 900 & 8.166 billion & Class C & High \\
\hline Raleigh & $\begin{array}{l}\text { Left Fork } \\
\text { Processing, } \\
\text { LLC }\end{array}$ & $\begin{array}{l}\text { Killarney } \\
\text { Refuse Area } \\
\text { Impoundment }\end{array}$ & 645 & 1.3353 billion & Class C & High \\
\hline Raleigh & $\begin{array}{l}\text { Goals Coal } \\
\text { Co. }\end{array}$ & $\begin{array}{l}\text { Shumate Coal } \\
\text { Refuse } \\
\text { Disposal } \\
\text { Facility }\end{array}$ & 385 & 2.8316 billion & $N / A$ & $N / A$ \\
\hline Raleigh & $\begin{array}{l}\text { Performance } \\
\text { Coal } \\
\text { Company }\end{array}$ & $\begin{array}{l}\text { Lower Big } \\
\text { Branch }\end{array}$ & $\begin{array}{l}\text { Not } \\
\text { listed }\end{array}$ & $19,548,242$ & N/A & Moderate \\
\hline Raleigh & $\begin{array}{l}\text { Clear Fork } \\
\text { Coal } \\
\text { Company }\end{array}$ & $\begin{array}{l}\text { Collins Fork } \\
\text { Refuse Dam }\end{array}$ & 380 & $1,055,826,446$ & Class C & $\mathrm{N} / \mathrm{A}$ \\
\hline Raleigh & $\begin{array}{l}\text { Clear Fork } \\
\text { Coal } \\
\text { Company }\end{array}$ & $\begin{array}{l}\text { McGraw Fork } \\
\text { Coal Refuse } \\
\text { Dam }\end{array}$ & 155 & 1.63 million & Class C & N/A \\
\hline Wyoming & $\begin{array}{l}\text { Kepler } \\
\text { Processing } \\
\text { Company, } \\
\text { Inc. }\end{array}$ & $\begin{array}{l}\text { Wallace } \\
\text { Cabin Branch }\end{array}$ & 388 & 995.15 million & Class C & Moderate \\
\hline Wyoming & $\begin{array}{l}\text { Laurel Run } \\
\text { Mining Co. }\end{array}$ & $\begin{array}{l}\text { Coal } \\
\text { Mountain No. } \\
\text { 9-B Slurry } \\
\text { Impoundment }\end{array}$ & 400 & $925,283,470$ & Class C & $\mathrm{N} / \mathrm{A}$ \\
\hline Wyoming & $\begin{array}{l}\text { Eastern } \\
\text { Associated } \\
\text { Coal Corp }\end{array}$ & $\begin{array}{l}\text { Upper Mill } \\
\text { Branch } \\
\text { Impoundment }\end{array}$ & 810 & $1,724,190,656$ & Class C & Low \\
\hline Wyoming & $\begin{array}{l}\text { U.S. Steel } \\
\text { Mining Co. }\end{array}$ & $\begin{array}{l}\text { Smith Branch } \\
\text { Refuse } \\
\text { Facility }\end{array}$ & 485 & 4.4808 billion & Class C & Low \\
\hline Wyoming & $\begin{array}{l}\text { Consolidation } \\
\text { Coal } \\
\text { Company }\end{array}$ & $\begin{array}{l}\text { Joe Branch } \\
\text { Coal Refuse } \\
\text { Dam }\end{array}$ & 345 & 2.0887 billion & Class C & High \\
\hline
\end{tabular}


Classes A, B, and C dams are defined in Section 3.4.b of Title 38 Series 4 of the Coal Related Dam Safety Rule. This is taken from the Department of Environmental Protection Division of Mining and Reclamation:

3.4.b.1. Class A Dams: Class A dams are those dams located in rural or agricultural areas where failure may damage non-residential and normally unoccupied buildings, rural or agricultural land, or secondary highways. Failure of Class A dam would cause only a loss of the dam itself and a loss of property use, such as use of related roads, with little additional damage to adjacent property. Any impoundment exceeding twenty-five (25) feet in height measured at the downstream toe or two hundred (200) acre-feet storage volume or having a watershed exceeding five hundred (500) acres should not be class A dam.

3.4.b.2. Class B Dams: Class B dams are those dams located in predominantly rural or agricultural areas where failure may damage isolated homes, primary highways, or minor railroads or may cause the interruption of public utility services. Failure of a Class B dam may cause great damage to property and project operations. Loss of human life resulting from failure of a class B dam must be unlikely. 3.4.b.3. Class C Dams: Class $C$ dams are those dams located where failure may cause a loss of human life or serious damage to homes, industrial and commercial buildings, important public utilities, primary highways or main haul roads. This classification must be used if failure would cause possible loss of human life.

*Description taken from the Mine Impoundment Location and Warning System http://www.coalimpoundment.com/info/classes.asp
Low Hazard Potential: Facilities in rural areas where failure would cause only slight damage, such as to farm buildings, forest, agricultural land, or minor roads.

Moderate Hazard Potential: Facilities in predominately rural areas where failure may damage isolated homes or minor railroads, disrupting services or important facilities.

High Hazard Potential: Facilities whose failure could reasonably be expected to cause loss of human life, serious damage to houses, industrial and commercial buildings, important utilities, highways, and railroads. *Description taken from the Mine Impoundment Location and Warning System

http://www.coalimpoundment.com/info/ classes.asp

All information compiled from the Mine Impoundment Location and Warning System http://www.coalimpoundment.com August 3, 2004 


\begin{tabular}{|c|c|c|c|c|}
\hline \multirow{2}{*}{\multicolumn{5}{|c|}{\begin{tabular}{|l|} 
Appendix 3 \\
Coal Slurry Spills for the Nine Counties \\
\end{tabular}}} \\
\hline & & & & \\
\hline \multirow{2}{*}{$\begin{array}{l}\text { County } \\
\text { Boone }\end{array}$} & \multirow{2}{*}{$\begin{array}{l}\text { Coal Company } \\
\text { Island Creek Coal Company }\end{array}$} & $\begin{array}{c}\text { Year of } \\
\text { Spill }\end{array}$ & $\begin{array}{c}\text { Spill Volume } \\
\text { (gallons) }\end{array}$ & \multirow{2}{*}{$\begin{array}{l}\text { Town } \\
\text { Bob White }\end{array}$} \\
\hline & & 1977 & $2,200,000$ & \\
\hline Boone & Ashland Coal & 1997 & 1,000 & Julian \\
\hline Boone & Ashland Coal & 1997 & $1,000,000$ & Julian \\
\hline Boone & Massey Energy Coal Company & 1999 & 1,500 & Sylvester \\
\hline Boone & Massey Energy Coal Company & 1999 & 2,200 & Sylvester \\
\hline Boone & Massey Energy Coal Company & 2001 & 30,000 & Uneeda \\
\hline Boone & Massey Energy Coal Company & 2001 & not listed & Quinland \\
\hline Boone & Massey Energy Coal Company & 2001 & 15,000 & Madison \\
\hline Boone & Massey Energy Coal Company & 2001 & not listed & Quinland \\
\hline Boone & Massey Energy Coal Company & 2002 & not listed & Quinland \\
\hline Boone & Arch Coal & 2002 & 25,000 & Julian \\
\hline Boone & Massey Energy Coal Company & 2003 & not listed & Uneeda \\
\hline Boone & Massey Energy Coal Company & 2003 & 250,000 & Prenter \\
\hline Boone & Massey Energy Coal Company & 2003 & 250,000 & Uneeda \\
\hline Logan & Pittston Coal Company & 1972 & $132,000,000$ & Lorado \\
\hline Logan & Belva Coal Company & 1981 & not listed & Earling \\
\hline Logan & Massey Energy Coal Company & 2001 & 50,000 & Dehue \\
\hline Logan & Massey Energy Coal Company & 2002 & 100,000 & Dehue \\
\hline Logan & Massey Energy Coal Company & 2003 & 27,000 & Dehue \\
\hline Logan & Falcon Land Co. & 2003 & not listed & Omar \\
\hline Logan & Falcon Land Co. & 2003 & not listed & Omar \\
\hline Logan & Massey Energy Coal Company & 2004 & not listed & Dehue \\
\hline McDowell & Abandoned Mine Land & 2002 & $10,000,000$ & Wilcoe \\
\hline Mingo & Massey Energy Coal Company & 2002 & 20,000 & Delbarton \\
\hline Mingo & Abandoned Mine Land & 2003 & not listed & Sprattsville \\
\hline Nicholas & Massey Energy Coal Company & 2003 & 1,000 & Summersville \\
\hline Raleigh & Philpot Coal Corp. & 1980 & 168,000 & not listed \\
\hline Raleigh & Peabody Coal Company & 1987 & $23,000,000$ & Montcoal \\
\hline Raleigh & Massey Energy Coal Company & 1999 & not listed & Sundial \\
\hline Raleigh & White Mountain Mining Co., LLC & 2003 & not listed & Rhodell \\
\hline
\end{tabular}

All information compiled from the Mine Impoundment Location and Warning System. http://www.coalimpoundment.com August 1,2004 